Chemican Techology

Division

Chemicel Technology

Division

Chernical Technology

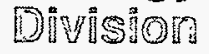

Chemicall Tednology

Division

Chemical Technology

Division

Chemical Technology

Division

Chemical Technology

Division

Chemical Tempology

DIn:sion

Chernical Techno:

0INIS:ON

Chemical Tectno:

Division

Chemigan "echnology

Divisien

Chemical Hegrnology

Division

Chemigan Technology

Division

Chemican Techology

Division

chemical Technology

DUy

Chemical Treminology

DivมีSใด

Chermical Ternology

Dingision
BF+?

FEB 12 4998

OSTI

ANL-95/23

\title{
Advanced Evaporator Technology Progress Report
}

FY 1992

by D. B. Chamberlain, S. E. Betts, J. C. Hutter, D. A. Johnson, M. D. Kaminski, S. Landsberger, R. A. Leonard, L. Nuñez, D. G. Wygmans, and G. F. Vandegrift

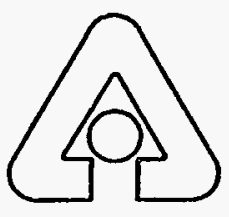

Argonne National Laboratory, Argonne, Illinois 60439 operated by The University of Chicago

for the United States Department of Energy under Contract W-31-109-Eng-38

Chemical Technology

Division

Chemical Technology

Diviฐjor?

Chemical Technology

Division

Chemical Teghrology

Qivision

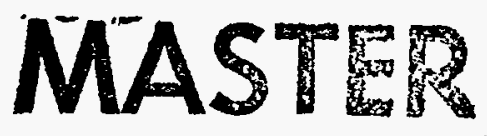

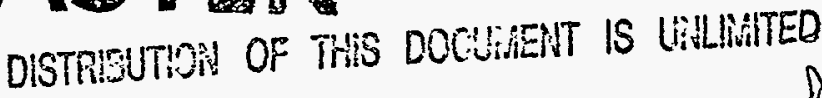

Be 
Argonne National Laboratory, with facilities in the states of Illinois and Idaho, is owned by the United States government, and operated by The University of Chicago under the provisions of a contract with the Department of Energy.

DISCLAIMER

This report was prepared as an account of work sponsored by an agency of the United States Government. Neither the United States Government nor any agency thereof, nor any of their employees, makes any warranty, express or implied, or assumes any legal liability or responsibility for the accuracy, completeness, or usefulness of any information, apparatus, product, or process disclosed, or represents that its use would not infringe privately owned rights. Reference herein to any specific commercial product, process, or service by trade name, trademark, manufacturer, or otherwise, does not necessarily constitute or imply its endorsement, recommendation, or favoring by the United States Government or any agency thereof. The views and opinions of authors expressed herein do not necessarily state or reflect those of the United States Government or any agency thereof.

Reproduced from the best available copy.

Available to DOE and DOE contractors from the Office of Scientific and Technical Information P.O. Box 62

Oak Ridge, TN 37831

Prices available from (423) 576-8401

Available to the public from the National Technical Information Service

U.S. Department of Commerce 5285 Port Royal Road Springfield, VA 22161 
$\overline{\mathrm{ANL}-95 / 23}$

\section{ARGONNE NATIONAL LABORATORY \\ 9700 South Cass Avenue \\ Argonne, Illinois 60439}

\section{ADVANCED EVAPORATOR TECHNOLOGY PROGRESS REPORT \\ FY 1992}

\section{by}

D. B. Chamberlain, S. E. Betts, ${ }^{*}$ J. C. Hutter, D. A. Johnson, ${ }^{* *}$ M. D. Kaminski, ${ }^{*}$ S. Landsberger, ${ }^{*}$ R. A. Leonard, L. Nuñez, D. G. Wygmans, and G. F. Vandegrift

Chemical Technology Division

January 1995

* Universiîy of Illinois, Champaign-Urbana, IL.

** Spring Arbor College, Spring Arbor, MI. 



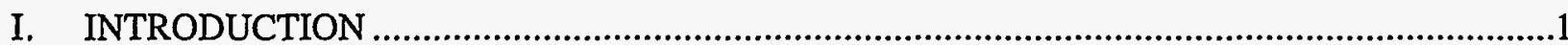

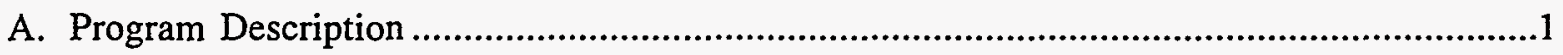

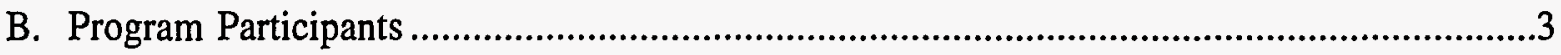

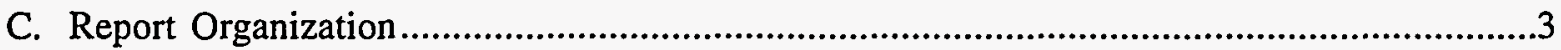

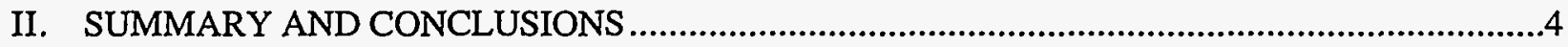

III. PLANT-SCALE EVAPORATOR DESIGN ...................................................................

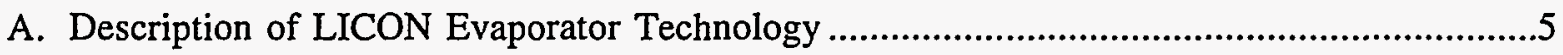

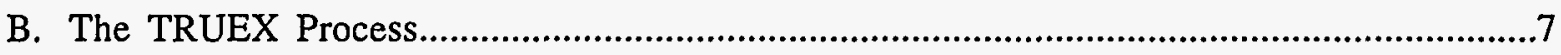

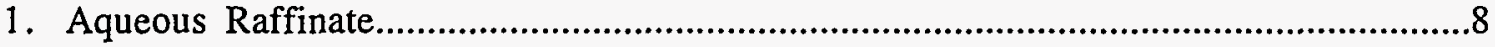

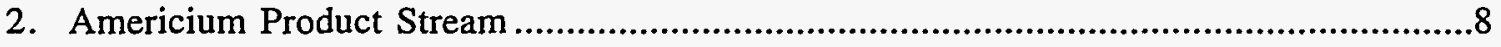

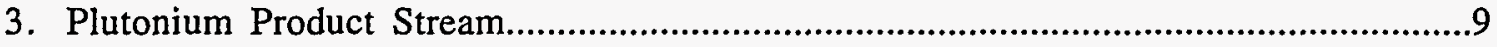

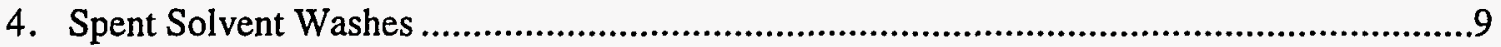

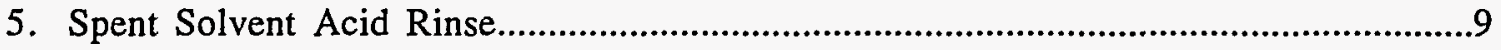

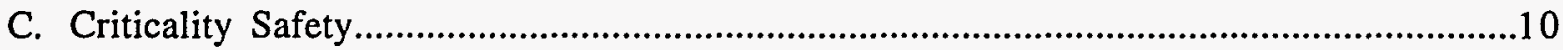

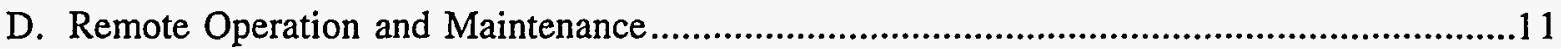

E. Self-Heating of TRU-Containing Solutions due to Alpha Decay ..................................11

F. Self-Heating of Fission Product-Containing Solutions .................................................14

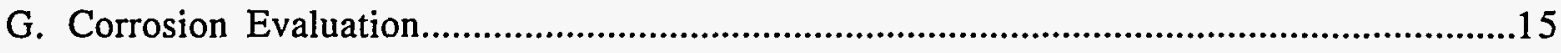

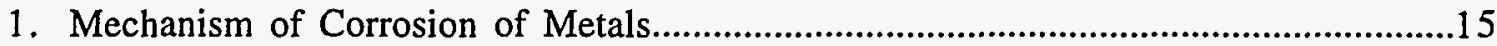

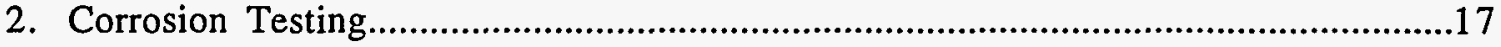

3. Corrosion-Resistant Materials in Nitric Acid Environments.......................................17

4. DOE Experience with 304 SS in Nuclear Fuel

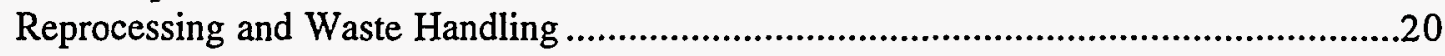

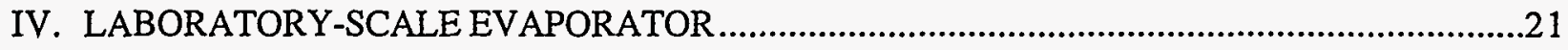

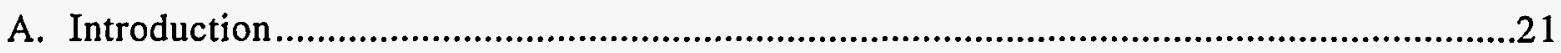

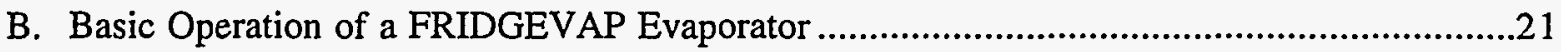

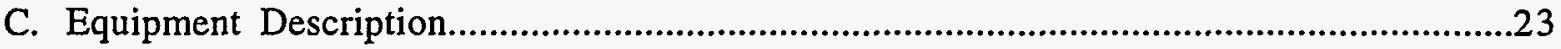

D. Corrosion Resistance of Materials Used in the Laboratory-Scale Evaporator......................26

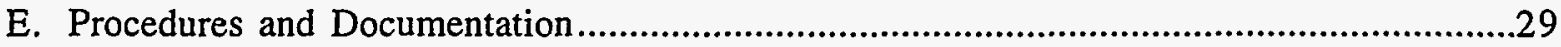




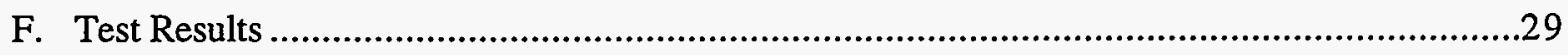

G. Preparations for Acidic Feeds .......................................................................................30

H. Neutron Activation Analysis .......................................................................................30

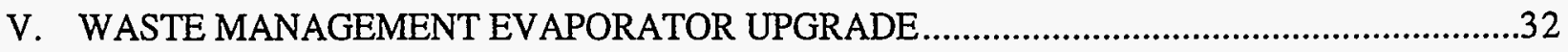

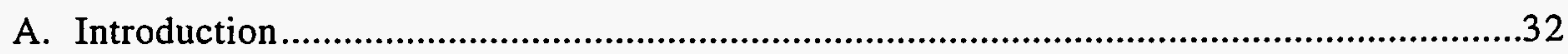

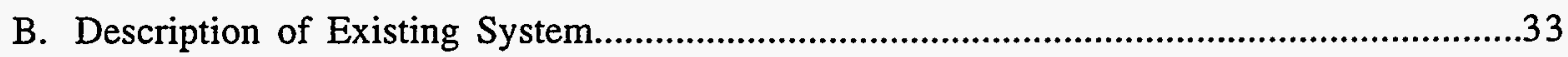

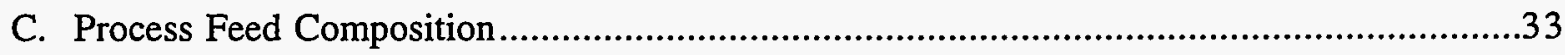

D. New Evaporator Design ................................................................................................3

VI. PHYSICAL PROPERTIES FOR EVAPORATOR LIQUIDS ....................................................

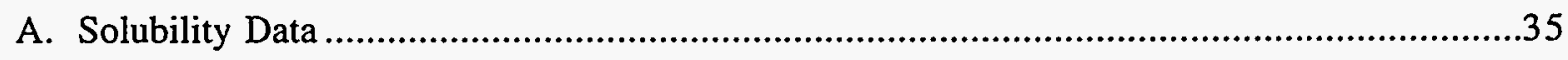

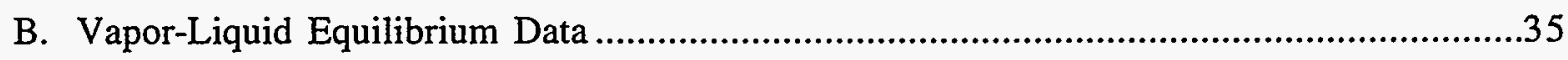

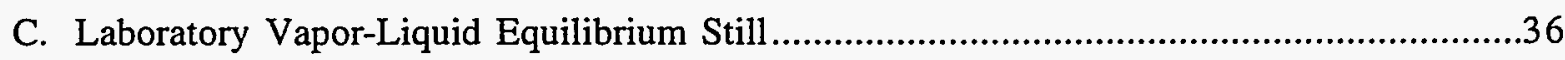

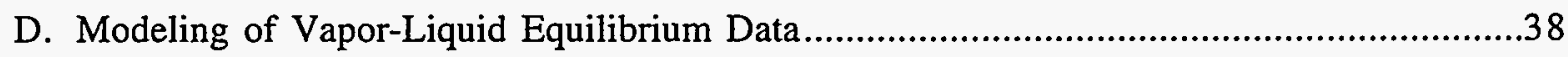

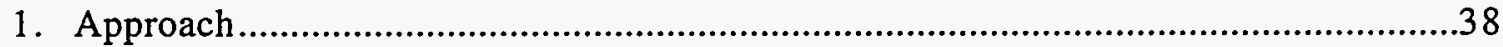

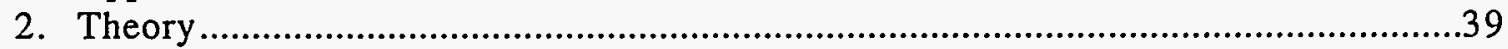

3. Activity Temperature Dependence Results ...................................................................41

4. Partial Pressure Calculations .......................................................................................49

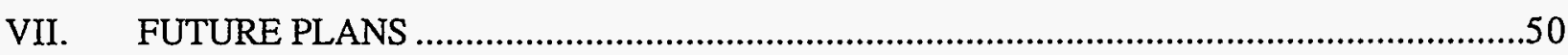

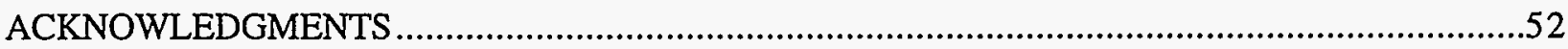

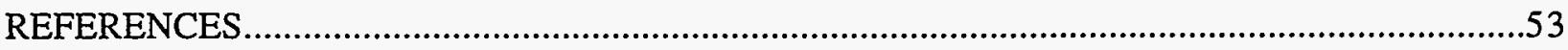

APPENDIX A. Solubility of Nitrate Salts in Aqueous Nitric Acid....................................................58

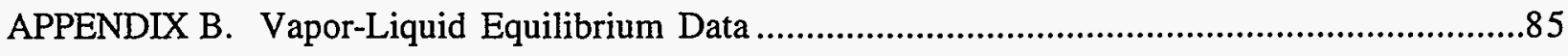

APPENDIX C. Neutron Activation Analysis.....................................................................116

APPENDIX D. Relationship between Activity and Chemical Potential...........................................122 


\section{LIST OF FIGURES}

No.

Title

Page

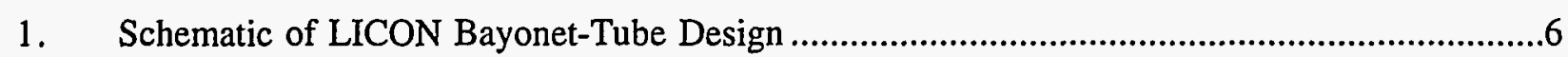

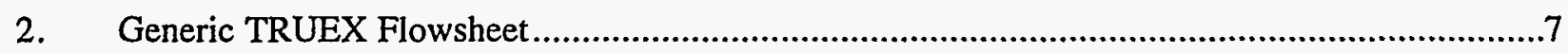

3. Spreadsheet Used to Calculate Heat Generation in a Specific TRU-Containing Solution..........12

4. Calculation of Self-Heating as a Solution Containing

$10^{-6} \mathrm{M}$ Am-241 Is Concentrated.

5. Calculation of Self-Heating as a Solution Containing

$10^{-7} \underline{\mathrm{M}} \mathrm{Np}-237$ Is Concentrated.

6. Calculation of Self-Heating as a Plutonium Solution Is Concentrated....................................14

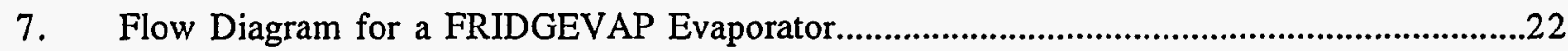

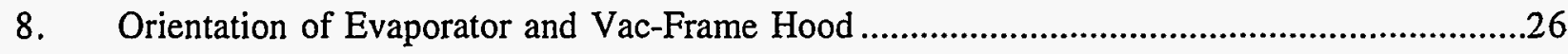

9. Location and Footprint of Evaporator and Hood within the Laboratory..............................27

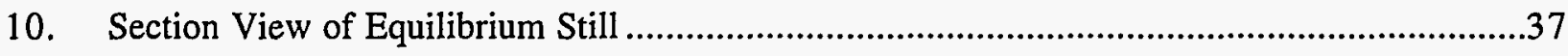

11. Calculated Best-Fit Line for Determining the Debye-Hückel

Constant A vs. Temperature

12. Calculated $\log \gamma$ vs. the Experimental Data of Davis and Lemire.

13. Calculated $\log \gamma$ with Temperature-Dependence of $A, \beta$, and $C$

vs. the Experimental Data.

14. Calculated $\log \gamma$ with Temperature-Dependence of $A, D$, and $E$

vs. the Experimental Data of Davis and Lemire.

15. Calculated $\log \gamma$ with Temperature-Dependence of $A, \beta$, and $C$

vs. the Experimental Data of Davis and Lemire.

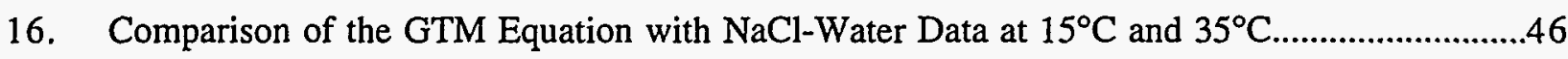

17. Comparison of the GTM Equation with $\mathrm{NaCl}$-Water Data at $25^{\circ} \mathrm{C}$ and $50^{\circ} \mathrm{C} \ldots \ldots \ldots \ldots \ldots \ldots . . . . . . . . . .46$

18. Calculated $\log \gamma$ for $\mathrm{NaCl}$ at $30^{\circ} \mathrm{C}$ vs. Reported Data .............................................47

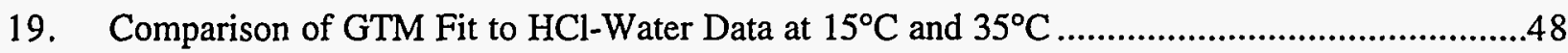

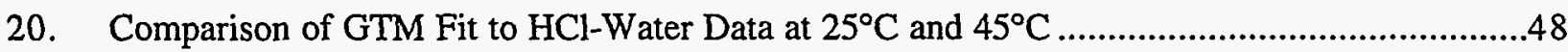




\section{LIST OF FIGURES (contd)}

No.

$\underline{\text { Title }}$

21. Agreement of the Calculated $\log \gamma$ for $\mathrm{HCl}$ with Reported Data at $30^{\circ} \mathrm{C}$

A-1. Solubility of $\mathrm{Al}^{3+}, \mathrm{Ca}^{2+}, \mathrm{Fe}^{3+}, \mathrm{La}^{3+}, \mathrm{Na}^{+}, \mathrm{Ni}^{2+}, \mathrm{Sm}^{3+}$, and $\mathrm{UO}_{2}{ }^{2+}$

Nitrates in Aqueous Nitric Acid at $25^{\circ} \mathrm{C}$.

A-2. Solubility of $\mathrm{Al}^{3+}, \mathrm{Ca}^{2+}, \mathrm{La}^{3+}, \mathrm{Na}^{+}$, and $\mathrm{Sm}^{3+}$ Nitrates in Aqueous Nitric Acid at $25^{\circ} \mathrm{C}$

A-3. Comparison of Solubilities for Aluminum and Sodium Nitrates in Nitric Acid.....

A-4. Solubility of $\mathrm{Ca}\left(\mathrm{NO}_{3}\right)_{2}$ in Nitric Acid at $25^{\circ} \mathrm{C}, 50^{\circ} \mathrm{C}$, and $60^{\circ} \mathrm{C}$.

A-5. Solubility of $\mathrm{La}\left(\mathrm{NO}_{3}\right)_{3}$ in Nitric Acid at $25^{\circ} \mathrm{C}$ and $50^{\circ} \mathrm{C}$.

A-6. Solubility of $\mathrm{NaNO}_{3}$ in Nitric Acid at $25^{\circ} \mathrm{C}, 35^{\circ} \mathrm{C}, 50^{\circ} \mathrm{C}$, and $75^{\circ} \mathrm{C}$

A-7. Solubility of $\mathrm{Sm}\left(\mathrm{NO}_{3}\right)_{3}$ in Nitric Acid at $25^{\circ} \mathrm{C}$ and $50^{\circ} \mathrm{C}$.

A-8. Solubility of $\mathrm{UO}_{2}\left(\mathrm{NO}_{3}\right)_{2}$ in Nitric Acid at $25^{\circ} \mathrm{C}, 49.1^{\circ} \mathrm{C}$, and $50^{\circ} \mathrm{C}$

A-9. Solubility of $\mathrm{UO}_{2}\left(\mathrm{NO}_{3}\right)_{2}$ in the Presence of a Second Nitrate Salt in

$1.5 \mathrm{M} \mathrm{HNO}_{3}$ at $25^{\circ} \mathrm{C}$

B-1. Comparison of Boiling-Temperature Data for Nitric Acid-Water System

at $760 \mathrm{mmHg}$.

B-2. Comparison of Vapor and Liquid Composition Data for Nitric Acid-Water System at $760 \mathrm{mmHg}$.

B-3. Comparison of Binary Nitric Acid-Water System at 50, 100, and $760 \mathrm{mmHg}$.

B-4. Comparison of Binary Nitric Acid-Water System at Various Pressures ..............................8 8

B-5. Comparison of Salting-Out Capacity for $6 \mathrm{~mol} \% \mathrm{La}, \mathrm{Ni}$, and $\mathrm{Na}$ at $400 \mathrm{mmHg} \ldots \ldots \ldots \ldots \ldots \ldots . . . . . . .89$

B-6. Concentration of Nitric Acid in the Vapor Phase as a Function of the

Concentration in the Liquid Phase of Aluminum Nitrate at $130 \mathrm{mmHg}$

B-7. Concentration of Nitric Acid in the Vapor Phase as a Function of the

Concentration in the Liquid Phase of Sodium Nitrate at $760 \mathrm{mmHg}$

B-8. Boiling Temperature vs. Concentrations of Nitric Acid and Sodium Nitrate

B-9. Nitric Acid Concentration in the Vapor Phase vs. System Pressure for the $\mathrm{HNO}_{3}-\mathrm{H}_{2} \mathrm{O}-\mathrm{UO}_{2}\left(\mathrm{NO}_{3}\right)_{2}$ at a Constant Salt Concentration of $3 \mathrm{~mol} \%$ 


\section{LIST OF FIGURES (contd)}

No.

Title

B-10. System Pressure vs. Boiling Temperature of the Nitric Acid-Water-3 mol\% Sodium Nitrate System

B-11. Vapor Pressure of Water over Aqueous Sulfuric Acid Solutions vs. Absolute Temperature.

B-12. Activity of Water vs. Aqueous Phosphoric Acid Concentrations.... .95

B-13. Concentration of Nitric Acid in the Vapor Phase above Solutions of Nitric Acid-Water-Sulfuric Acid at $760 \mathrm{mmHg}$.

B-14. Temperature vs. Nitric Acid in the Liquid Phase for Nitric Acid-Water-Sulfuric Acid Systems at $760 \mathrm{mmHg}$

C-1. Gamma Spectrum from Irradiated Samarium Standard. 


\section{LIST OF TABLES}

No.

Title

Page

1. Conversion Factors Used to Calculate Heat Generation from Alpha Decay 11

2. Corrosion Data for Steels in Nitric Acid Solutions. .18

3. Simulated Evaporator Solution used in Los Alamos Evaporator Study

4. Effect of $\mathrm{NO}_{3}^{-}$on the Corrosion of $316 \mathrm{SS}$ at $120^{\circ} \mathrm{C}$.

5. General Specifications for FRIDGEVAP FVP-C3.

6. Corrosion Characteristics of PVC, CPVC, Acrylic, and Polypropylene in Hydrofluoric, Nitric, Oxalic, and Phosphoric Acids .28

7. Corrosion Rates for Titanium in Hydrofluoric, Nitric, Oxalic, and Phosphoric Acids .29

8. Calculated and Actual Concentrations of Samarium Standards. .32

9. Evaporator Feed Solution Composition. .34

10. Comparison of Calculated $\mathrm{P}\left(\mathrm{H}_{2} \mathrm{O}\right)$ and $\mathrm{P}\left(\mathrm{HNO}_{3}\right)$ from the Modified GTM to Experimental Data of Yakimov.

11. Major Milestones, FY 1993 through FY 1996. 51

A-1. List of Systems Presented in Figure Format in Appendix A .58

A-2. List of Systems Present in Table Format in Appendix A..................................................59

A-3. Apparent Molar Volumes (AMV) for Selected Ions. .60

A-4. Solubility Data for $\mathrm{Al}\left(\mathrm{NO}_{3}\right)_{3}$ in Nitric Acid-Water at $25^{\circ} \mathrm{C}$ 65

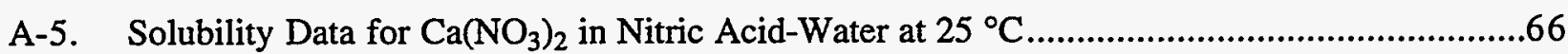

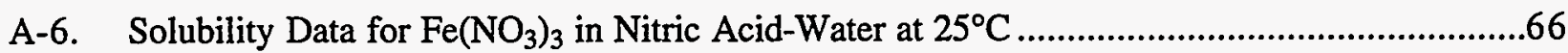

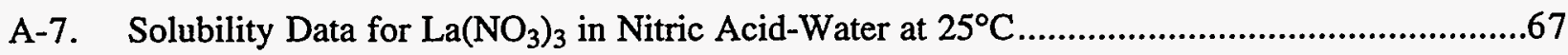

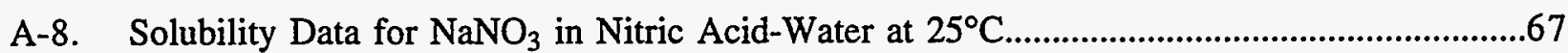

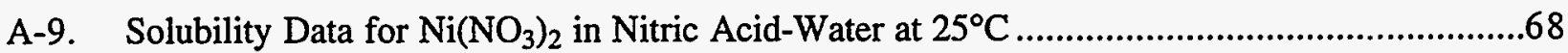

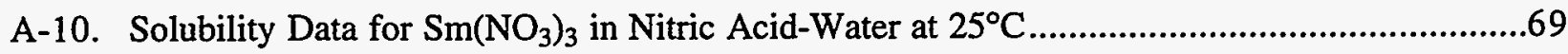

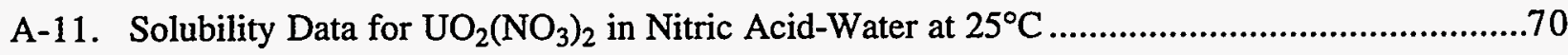




\section{LIST OF TABLES (contd)}

No.

Title

Page

A-12. Solubility Data for $\mathrm{Al}\left(\mathrm{NO}_{3}\right)_{3}$ in Nitric Acid-Water at $20^{\circ} \mathrm{C}$

A-13. Solubility Data for $\mathrm{Al}\left(\mathrm{NO}_{3}\right)_{3}$ in Nitric Acid-Water at $40^{\circ} \mathrm{C}$

A-14. Solubility Data for $\mathrm{Al}\left(\mathrm{NO}_{3}\right)_{3}$ in Nitric Acid-Water at $60^{\circ} \mathrm{C}$ .71

A-15. Solubility Data for $\mathrm{NaNO}_{3}-\mathrm{KNO}_{3}$ in Nitric Acid-Water at $25^{\circ} \mathrm{C}$.

A-16. Solubility Data for $\mathrm{Ca}\left(\mathrm{NO}_{3}\right)_{2}-\mathrm{Sr}\left(\mathrm{NO}_{3}\right)_{2}$ in Nitric Acid-Water at $25^{\circ} \mathrm{C}$. .72

A-17. Solubility Data for $\mathrm{Fe}\left(\mathrm{NO}_{3}\right)_{3}-\mathrm{Th}\left(\mathrm{NO}_{3}\right)_{4}$ in Nitric Acid-Water at $20^{\circ} \mathrm{C}$

A-18. Solubility Data for $\mathrm{UO}_{2}\left(\mathrm{NO}_{3}\right)_{2}-\mathrm{Mg}\left(\mathrm{NO}_{3}\right)_{2}$ in Nitric Acid-Water at $25^{\circ} \mathrm{C}$

A-19. Solubility Data for $\mathrm{UO}_{2}\left(\mathrm{NO}_{3}\right)_{2}-\mathrm{Ca}\left(\mathrm{NO}_{3}\right)_{2}$ in Nitric Acid-Water at $25^{\circ} \mathrm{C}$ .73

A-20. Solubility Data for $\mathrm{UO}_{2}\left(\mathrm{NO}_{3}\right)_{2}-\mathrm{Cu}\left(\mathrm{NO}_{3}\right)_{2}$ in Nitric Acid-Water at $25^{\circ} \mathrm{C}$. .74

A-21. Solubility Data for $\mathrm{Ca}\left(\mathrm{NO}_{3}\right)_{2}$ in Nitric Acid-Water at $25^{\circ} \mathrm{C}$ .74

A-22. Solubility Data for $\mathrm{Ca}\left(\mathrm{NO}_{3}\right)_{2}$ in Nitric Acid-Water at $50^{\circ} \mathrm{C}$ .75

A-23. Solubility Data for $\mathrm{Ca}\left(\mathrm{NO}_{3}\right)_{2}$ in Nitric Acid-Water at $50^{\circ} \mathrm{C}$ .75

A-24. Solubility Data for $\mathrm{Ca}\left(\mathrm{NO}_{3}\right)_{2}$ in Nitric Acid-Water at $60^{\circ} \mathrm{C}$ .76

A-25. Solubility Data for $\mathrm{La}\left(\mathrm{NO}_{3}\right)_{3}$ in Nitric Acid-Water at $25^{\circ} \mathrm{C}$ .76

A-26. Solubility Data for $\mathrm{La}\left(\mathrm{NO}_{3}\right)_{3}$ in Nitric Acid-Water at $50^{\circ} \mathrm{C}$ .77

A-27. Solubility Data for $\mathrm{NaNO}_{3}$ in Nitric Acid-Water at $35^{\circ} \mathrm{C}$. .77

A-28. Solubility Data for $\mathrm{NaNO}_{3}$ in Nitric Acid-Water at $50^{\circ} \mathrm{C}$. .78

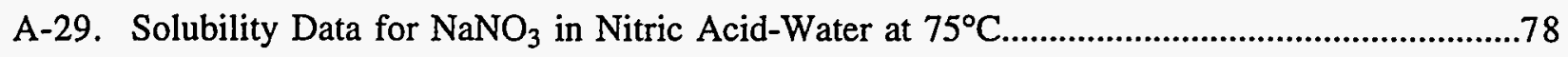

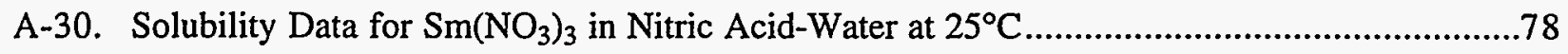

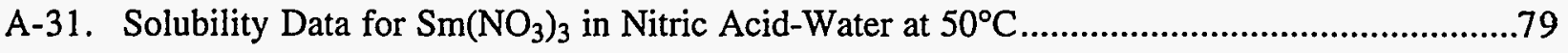

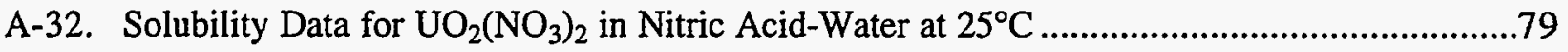

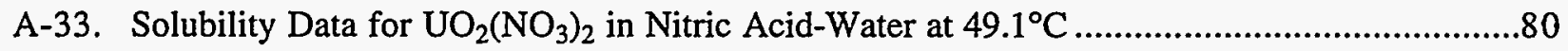

A-34. Solubility Data for $\mathrm{UO}_{2}\left(\mathrm{NO}_{3}\right)_{2}$ in Nitric Acid-Water at $50^{\circ} \mathrm{C}$ .81 


\section{LIST OF TABLES (contd)}

No. $\underline{\text { Title }}$

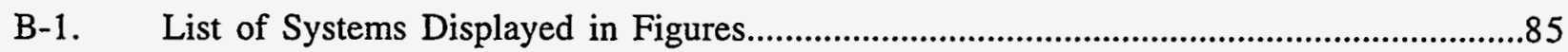

B-2. List of Systems Described in Tables...................................................................86

B-3. Comparison of Data for Binary $\mathrm{HNO}_{3}-\mathrm{H}_{2} \mathrm{O}$ Systems at $760 \mathrm{mmHg}$

from Ellis and Thwaites

B-4. Comparison of Data for Binary $\mathrm{HNO}_{3}-\mathrm{H}_{2} \mathrm{O}$ Systems at $760 \mathrm{mmHg}$

from Boublik et al.

B-5. Comparison of Data for Binary $\mathrm{HNO}_{3}-\mathrm{H}_{2} \mathrm{O}$ Systems at $760 \mathrm{mmHg}$ from Prosek..............98

B-6. Comparison of Data for Binary $\mathrm{HNO}_{3}-\mathrm{H}_{2} \mathrm{O}$ Systems at $760 \mathrm{mmHg}$

from Potier and Alger.

B-7. Data for Nitric Acid-Water System at a Pressure of $50 \mathrm{mmHg}$....................................100

B-8. Data for Nitric Acid-Water System at a Pressure of $100 \mathrm{mmHg}$..................................100

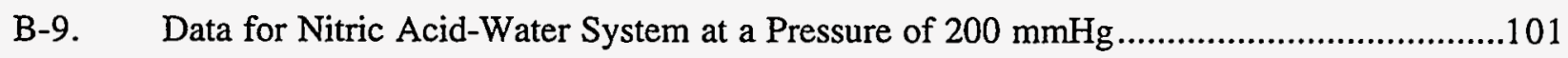

B-10. Data for Nitric Acid-Water System at a Pressure of $400 \mathrm{mmHg}$...................................101

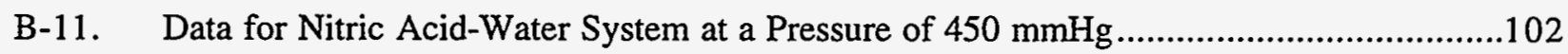

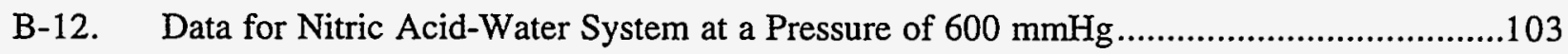

B-13. Comparison of Salting-Out Capacity of $6 \mathrm{~mol} \% \mathrm{La}, \mathrm{Ni}$, and $\mathrm{Na}$ at $400 \mathrm{mmHg} . . . \ldots \ldots \ldots . . .104$

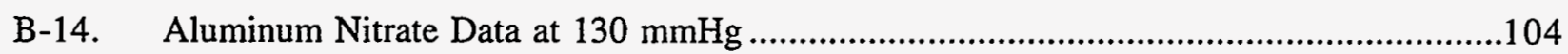

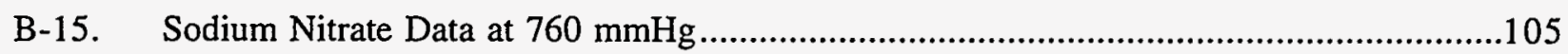

B-16. Vapor-Liquid Equilibrium Data for $\mathrm{HNO}_{3}-\mathrm{H}_{2} \mathrm{O}-\mathrm{UO}_{2}\left(\mathrm{NO}_{3}\right)_{2}$ System

at Three Pressures for a Constant Salt Concentration of $3 \mathrm{~mol} \%$.

B-17. Vapor Pressure above Aqueous Sulfuric Acid Solutions vs.

Temperature and wt\% Sulfuric Acid

B-18. Constants A and B as Determined by Least-Squares Method to fit Vapor Pressure of Water Data in Table B-16 to Eq. B-3

B-19. Activity of Water over Aqueous Phosphoric Acid at $25^{\circ} \mathrm{C}$

B-20. Equilibrium Data for the Nitric Acid-Water-Sulfuric Acid System

at $760 \mathrm{mmHg}$ 


\title{
ADVANCED EVAPORATOR TECHNOLOGY \\ PROGRESS REPORT \\ FY 1992
}

by
D. B. Chamberlain, S. E. Betts, J.
C. Hutter, D. A. Johnson, ${ }^{* *}$ M.
D. Kaminski, ${ }^{* * *}$
S. Landsberger, ${ }^{* * * *}$ R. A. Leonard, L. Nuñez, D. G. Wygmans, and G. F. Vandegrift

\begin{abstract}
This report summarizes the work that was completed in FY 1992 on the program "Technology Development for Concentrating Process Streams." The purpose of this program is to evaluate and develop evaporator technology for concentrating radioactive waste and product streams such as those generated by the TRUEX process. Concentrating these streams and minimizing the volume of waste generated can significantly reduce disposal costs; however, equipment to concentrate the streams and recycle the decontaminated condensates must be installed. LICON, Inc., is developing an evaporator that shows a great deal of potential for this application. In this report, concepts that need to be incorporated into the design of an evaporator operated in a radioactive environment are discussed. These concepts include criticality safety, remote operation and maintenance, and materials of construction. Both solubility and vapor-liquid equilibrium data are needed to design an effective process for concentrating process streams Therefore, literature surveys were completed and are summarized in this report. A model that is being developed to predict vapor phase compositions is described. A laboratory-scale evaporator was purchased and installed to study the evaporation process and to collect additional data. This unit is described in detail. Two new LICON evaporators are being designed for installation at Argonne-East in FY 1993 to process low-level radioactive waste generated throughout the laboratory. They will also provide operating data from a full-sized evaporator processing radioactive solutions. Details on these evaporators are included in this report.
\end{abstract}

\section{INTRODUCTION}

\section{A. Program Description}

This report summarizes the work that was completed in FY 1992 on the field work proposal titled "Technology Development for Concentrating Process Streams." The purpose of this

* Graduate student at University of Illinois, Champaign-Urbana. S. Bett's research was performed under appointment to the Civilian Radioactive Waste Management Fellowship program administered by Oak Ridge Institute for Science and Education for the U. S. Department of Energy.

** Faculty Research Participant, Spring Arbor College, Spring Arbor, Michigan.

*** Undergraduate student from University of Illinois, Champaign-Urbana.

**** Associate Professor, Department of Nuclear Engineering, University of Illinois, Champaign-Urbana. 
program is to evaluate and develop evaporator technology for concentrating radioactive waste and product streams, such as those generated by the TRUEX process. This program allows the Department of Energy (DOE) to take advantage of state-of-the-art evaporation equipment that has been developed over the past 30 years for commercial applications. DOE's evaporator technology is typically 40 years old and would benefit greatly from this advanced technology available in the private sector.

Radioactive wastes, which are being generated at various DOE sites around the country, have the potential to be concentrated by evaporation. Minimizing the volume of waste generated, disposal costs can be significantly reduced. This process, however, requires installing equipment for (1) concentrating radioactive waste streams and (2) recycling the decontaminated condensates. An evaporator that shows a great deal of potential for this application is being developed by LICON, Inc. (Pensacola, FL).

In this multiyear program, our goal is to apply LICON's evaporator designs to the processing of highly acidic, highly radioactive solutions. The technical scope of this project will include (1) evaluating the economic benefits/detriments of installing this equipment, (2) evaluating the effects of concentration on plant operations, (3) modifying a commercial evaporator for remote operation and maintenance, (4) demonstrating laboratory- and pilot-plant scale operation equipment at ANL, (5) demonstrating a plant-scale LICON-designed evaporator, and (6) demonstrating in-plant the full-sized evaporator in a DOE processing/production facility.

Processing highly acidic, highly radioactive waste solutions requires special design considerations that are not required in the commercial sector, such as remote operability and maintenance and criticality safety control. The key issue for this program is the high decontamination factors (DFs) that need to be demonstrated in this equipment. High DFs would allow acids to be recycled from the evaporator, further reducing the volume of waste generated and minimizing the need to purchase new chemicals.

One key change to the program during this year was to incorporate a project initiated by Argonne National Laboratory's (ANL's) Waste Management Operations (WMO) Division, which is preparing to replace two low-level waste evaporators that have been in operation at Argonne for over 30 years with LICON evaporators. These new evaporators, now scheduled for design, purchase, and installation in FY 1993, will collect operating data on the processing of actual waste solutions. Joining WMO's ongoing waste minimization program with CMT's R\&D program enhances both programs. Benefits of this joint program to CMT include (1) valuable operating experience on a full-scale LICON-designed evaporator in the third year of the program, (2) a significant capital equipment savings for the R\&D program, and (3) evaporator demonstration on real waste solutions early in the program. Benefits to WMO include CMT's technical support for their daily operation.

This program is a logical extension of the TRUEX program, under development at ANL since the early 1980s [CHAIKO-1988A, CHAIKO-1988B, CHAIKO-1988C, HORWITZ-1985, HORWITZ-1986, HORWITZ-1988, LEONARD, NASH, REGALBUTO, SCHULZ, SIMONZADEH, STEINDLER, TSE]. TRUEX is a highly efficient solvent extraction procedure to separate small quantities of transuranic (TRU) elements (e.g., $\mathrm{Am}, \mathrm{Pu}, \mathrm{Cm}$ ) from aqueous nitrate or chloride solutions that are typically generated in reprocessing plant operations or in plutonium production and purification operations. The TRU elements can be sufficiently separated from the resulting waste solutions to warrant disposal as a nonTRU waste. The waste and product solutions generated by the TRUEX process are fairly dilute and contain recoverable quantities of nitric acid. By processing 
these solutions through an evaporator, nitric acid can be recovered for reuse, thereby minimizing the volume of waste generated and the amount of fresh nitric acid needed.

\section{B. Program Participants}

Four organizations are cooperating with CMT in this program: WMO; LICON, Inc., an evaporator company located in Pensacola, FL; the University of Illinois Nuclear Engineering Department (Urbana, IL); and the Spring Arbor College Chemistry Department (Spring Arbor, MI).

As described above, WMO contributes expertise in operating waste-solution evaporators for the past 30 years. Replacing their existing low-level waste evaporators with two new units benefits our program, just as our R\&D program benefits their daily operation.

LICON personnel have acquired over thirty patents in evaporator design and a combined experience of more than 30 years in the industry. This fifteen-year-old corporation has speciaiized in developing evaporator technology for recovering metals and chemicals and for reducing the volume of industrial waste and rinse waters. LICON has fabricated several evaporators for processing low-level radioactive waste over the past several years.

A graduate student (M. S. in Nuclear Engineering at Illinois) has been working on several phases of this program. Literature reviews on solubility and vapor/liquid equilibrium data for nitric acid and nitrate salt systems have been completed. This data is needed to deterine the amount of concentration that can be achieved wihout precipitating components and predicting the vapor phase concentrations of the various components processed. He is now developing neutron activation analysis (NAA) to measure decontamination factors that we achieve in the various pilot plant- and full-scale evaporator units. His work is also supported by the Office of Civilian Radioactive Waste Management.

A visiting professor from the Spring Arbor College Chemistry Department joined Argonne this summer to participate in the Faculty Research Participation Program and will continue to participate during the school year at Spring Arbor College. His task is to develop a computer model which uses aqueous-phase activities for predicting vapor-phase compositions.

\section{Report Organization}

This report describes the work that was completed in FY 1992. The report is organized into six main sections plus four appendices. The first two sections introduce the program (Section I) and summarize the results and conclusions (Section II). The next three sections (Sections III, IV, and V) describe various aspects of evaporator design for three different evaporators: laboratory-scale, pilot plant-scale, and WMO units. Topics covered in these three sections include a general description of LICON evaporator technology, criticality safety, remote operation and maintenance, solution self-heating due to radioactive decay, corrosion of various evaporator construction materials, and neutron activation analysis as applied to measuring decontamination factors.

The sixth section of the report, Physical Properties for Evaporator Liquids (Section VI), summarizes results from three literature surveys. In these surveys, solubility data, vaporliquid equilibrium data for nitric acid and nitrite salt systems, and information on laboratory stills were compiled. Also included in this section of the report is a description of the model developed to 
predict vapor compositions. The last section (Section VII) describes the plans for the upcoming years.

Four appendices are attached to the report. Appendices A and B give specific details on the literature surveys for both the solubility data (Appendix $A$ ) and vapor-liquid equilibrium data (Appendix B). Appendix $\mathrm{C}$ describes neutron activation analysis in detail. The last appendix (Appendix D) describes the relationship between activity and chemical potential.

\section{SUMMARY AND CONCLUSIONS}

Designing an effective evaporation process to concentrate aqueous process streams requires both solubility and vapor-liquid equilibrium data. Solubility data are needed to determine the amount of solution concentration that can be achieved without precipitating components from the solution. Vapor-liquid equilibrium data are needed to predict the vapor-phase concentrations for the various solution compositions that will be processed. Literature surveys were completed on both topics.

The conditions at which solids precipitate from mixed acid/metal salt solutions versus temperature, pressure, and composition were obtained from these surveys. Solubility data for nitrate salts of aluminum, calcium, iron, lanthanum, nickel, samarium, sodium, and uranyl as a function of acid concentration at various temperatures are reported. Among these data, aluminum nitrate had the lowest solubility of the nitrate salts studied.

The effects of metal nitrate salts and system pressure on vapor-liquid equilibria of aqueous $\mathrm{HNO}_{3}$ solutions are reported. Several trends are evident from these data. Reducing the pressure decreases the boiling point of the system, but has little impact on the vapor-phase compositions. Except for potassium nitrate, the salts reduce the solubility of nitric acid, which tends to salt out into the vapor phase. The solution boiling point also tends to increase as the salt concentration increases.

Predicting the vapor composition in equilibrium with complex aqueous solutions is necessary in order to design evaporator systems for recovering nitric acid from process and product streams. According to Raoult's law, the thermodynamic activities of nitric acid and water in an aqueous solution are proportional to their partial pressures in the vapor phase above the solution. Work was begun in FY 1992 to extend the calculating ability of the Generic TRUEX Model (GTM) from activities only at $25^{\circ} \mathrm{C}$ to activities over the range of temperatures expected in the evaporator. For this task, temperature dependencies were added to the modified Bromley equations used in the GTM. Results show that the data for the binary system (nitric acid-water) can be fit if first-order temperature dependencies are specified for three of the six constants in the modified Bromley equation. Our work in fitting literature data for vapor compositions above ternary systems that include a nitrate salt shows that temperature dependencies for the activities of all components may be necessary to accurately predict vapor compositions.

Various aspects of processing highly acidic, highly-radioactive waste solutions in an evaporator were investigated that included nuclear criticality safety, solution self-heating due to radioactive decay, corrosion of potential materials of construction, and remote operation and maintenance. Nuclear criticality safety can be achieved by geometry control if the maximum diameter of the evaporator body is $15 \mathrm{~cm}(6 \mathrm{in}$.). Because of the low concentration of fissile nuclides in many nuclear wastes, administrative control may be an alternative control method in some cases. 
Self-heating of concentrate solutions, which is caused by the radioactive decay of typical fission-product (strontium and/or cesium and their short-lived daughters) or TRU-product solutions from Hanford tank waste, can be accounted for but should not be of great significance to evaporator operation. Generally, the estimated $0.1-30 \mathrm{~W} / \mathrm{L}$ due to self-heating will be negligible compared to supplied heat input.

Selecting materials for constructing a pilot plant-scale evaporator is important, since nuclear waste evaporators commonly experience mechanical failure due to corrosion. A preliminary screening of materials was made using published handbooks and reports. The most common material was 304 stainless steel (SS). Potentially useful materials need to be screened by immersionor electrochemical-corrosion tests. The DOE has considerable experience in adjusting the chemistry of waste solutions and in heat treatment and manufacturing practices to minimize corrosion, especially in 304 SS vessels. In the future, more exotic materials than 304 SS may be available, such as titanium or Hastelloy G-30. We are still working on this problem.

We surveyed the literature for remote operation and maintenance aspects of equipment design and found a few valuable sources. These sources provide basic objectives and detailed checklists for equipment design.

A laboratory-scale evaporator has been purchased and installed. It will be used to gather experimental data that will aid in the eventual design of a plant-scale evaporator and to gain experience for operating a LICON evaporator. Procedures for the safe operation and testing of the evaporator have been written. After modifications were made to the evaporator, two experimental runs were made using neutral salt solutions. Further modifications will be necessary before acidic solutions can be processed.

Two new LICON-designed evaporator units, each capable of processing $340 \mathrm{~L} / \mathrm{hr}$ (90 GPH), are being designed for installation at Argonne-East in FY 1993. These units will be used to process low-level radioactive waste generated throughout the laboratory and will provide operating experience. Joining WMO's ongoing waste minimization program with CMT's R\&D program enhances both programs. Benefits of this joint program include (1) valuable operating experience on . a full-scale LICON-designed evaporator, (2) a significant capital equipment savings for the R\&D program, because lessons learned from operating these units will be incorporated into the pilot plantscale unit, (3) an evaporator demonstration using actual waste solutions early in the program, and (4) technical support for WMO's daily operation.

\section{PLANT-SCALE EVAPORATOR DESIGN}

This section is divided into seven parts that describe different facets of plant-scale evaporator design and operation. The first part describes the LICON evaporator. The second part uses TRUEX process effluent streams as feeds typical of Hanford tank wastes. The next three parts discuss concerns due to criticality, remote operation and maintenance, and solution self-heating due to TRU and fission-product radioactive decay. The last part looks at potential materials of construction based on corrosion resistance.

\section{A. Description of LICON Evaporator Technology}

LICON specializes in the design and manufacture of horizontal-tube vacuum evaporators that are compact and energy efficient. Sizes range from $11 \mathrm{~L} / \mathrm{hr}(3 \mathrm{GPH})$ to approximately $1900 \mathrm{~L} / \mathrm{hr}(500 \mathrm{GPH})$. Many innovative features have been incorporated into their 
evaporators, including some that were developed in the early 1980 s with support from the DOE. LICON's designs incorporate horizontal heat exchangers, which require less headroom than verticaltube heat exchangers. This design feature is important, since we may install these units in shielded cells, which typically do not have a lot of headroom.

LICON also incorporates bayonet tubes in their heat exchangers. A diagram of a single bayonet tube is shown in Fig. 1. For heating, the heating fluid flows down through the annulus of the tube and exits through the center of the tube. The outside of the tube is in contact with the boiling solution. Bayonet tubes, although more expensive to manufacture, are effective because they allow for (1) high velocities and turbulence that improve heat transfer coefficients, (2) high heat transfer area, and (3) easy venting of noncondensables from the heat exchanger. These tubes are typically manufactured from titanium.

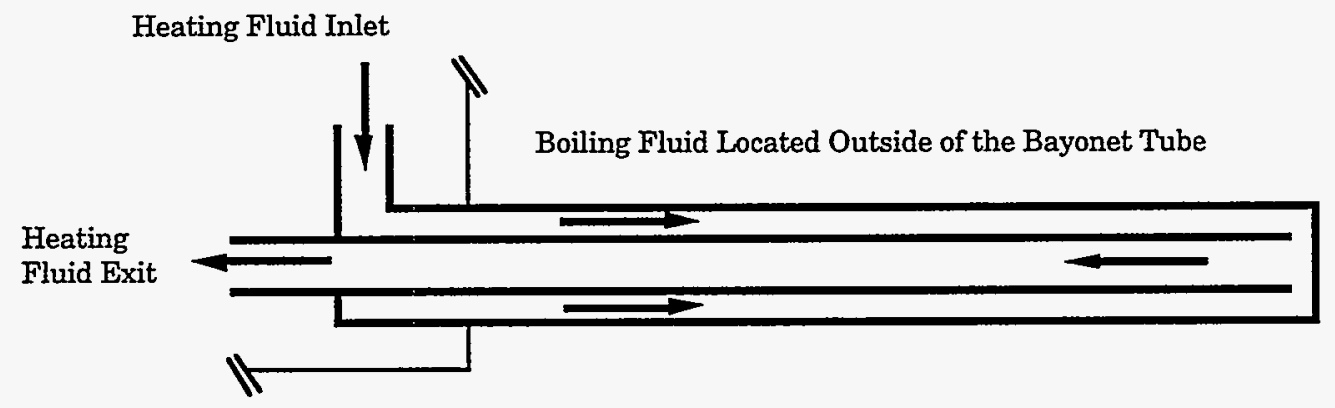

NOTE: Arrows indicate direction of solution flow

Fig. 1. Schematic of LICON Bayonet-Tube Design

These evaporators operate under vacuum, so operating temperatures are much lower than atmospheric evaporators. Lower system temperatures often allow less expensive construction materials to be used, such as fiberglass and CPVC/PVC. For nuclear applications, however, stainless steel and other alloys are available.

System vacuum is produced by eductors, not vacuum pumps, which increase the reliability of the units. LICON also relies on forced circulation of the concentrate solution through the evaporator, which aids in heat transfer, decreases scaling tendencies, and maintains solids suspended in solution. Flow rates of the concentrate are typically 10 times the rated capacity of the evaporator. Advanced microprocessor control systems to make the units fully automated are also available from LICON. This development is important, since remote operation is necessary.

LICON manufactures several different evaporator designs, including single- and multiple-effect units, a multistage flash unit called FLASHVAP, a vapor compression unit called AQUAVAP, and an all-electric, low-temperature evaporator called FRIDGEVAP. LICON specializes in developing evaporators to recover metals and chemicals and to reduce the volumes of industrial waste and rinse waters; more recently, they entered the market for processing low-level radioactive waste solutions.

Four LICON evaporators are in place processing low-level radioactive waste solutions. An $1100-\mathrm{L} / \mathrm{hr}$ (300-GPH) evaporator (concentrator) is operating at Three Mile Island, Unit 2, where 
over $3,800,000 \mathrm{~L}(1,000,000 \mathrm{gal})$ of low-level radioactive waste have been successfully processed. Decontamination factors have been reported in excess of 1000 for boron and 1 million for other radionuclides [CREMEANS]. Three LICON Transvap ${ }^{\text {TM }}$ systems, each consisting of a 1900-L/hr (500-GPH) vapor compression evaporator and a 950-L/hr (250-GPH) flash evaporator, are currently being setup at Rocky Flats, where they will concentrate solar pond water. Approximately 30 million liters ( 8 million gal) of waste will be reduced to less than $38,000 \mathrm{~L}(10,000 \mathrm{gal})$.

The purpose of this program is to develop an evaporator for processing highly acidic,

highly radioactive waste solutions. Based upon initial conversations with LICON, we originally planned to modify a FRIDGEVAP unit. We believed that the heat pump and Freon recirculating system incorporated into the FRIDGEVAP design could be installed inside a shielded cell or canyon facility. However, these units can only operate up to $60^{\circ} \mathrm{F}\left(140^{\circ} \mathrm{F}\right)$; to operate at higher temperatures, electric heaters or steam are needed. Because of the high salt content of the solutions that we plan to process, we expect to operate routinely at temperatures greater than $60^{\circ} \mathrm{F}\left(140^{\circ} \mathrm{F}\right)$. LICON's singleeffect evaporators are now being evaluated for our application. To complete this evaluation, an 11$\mathrm{L} / \mathrm{hr}$ (3-GPM) laboratory-scale evaporator was purchased from LICON and installed at ANL. This unit, a FRIDGEVAP with supplemental electrical heaters, is described in detail in Section IV. Both the Freon and electric heating systems will be evaluated.

\section{B. The TRUEX Process}

The TRUEX process is a highly efficient solvent extraction procedure to separate small quantities of transuranic elements from aqueous nitrate or chloride solutions that are typically generated in reprocessing plant operations or in plutonium production and purification operations. The resulting solutions can be separated sufficiently from the TRU elements to warrant disposing of them as nonTRU waste. A simplified schematic of a typical TRUEX flowsheet is shown in Fig. 2.

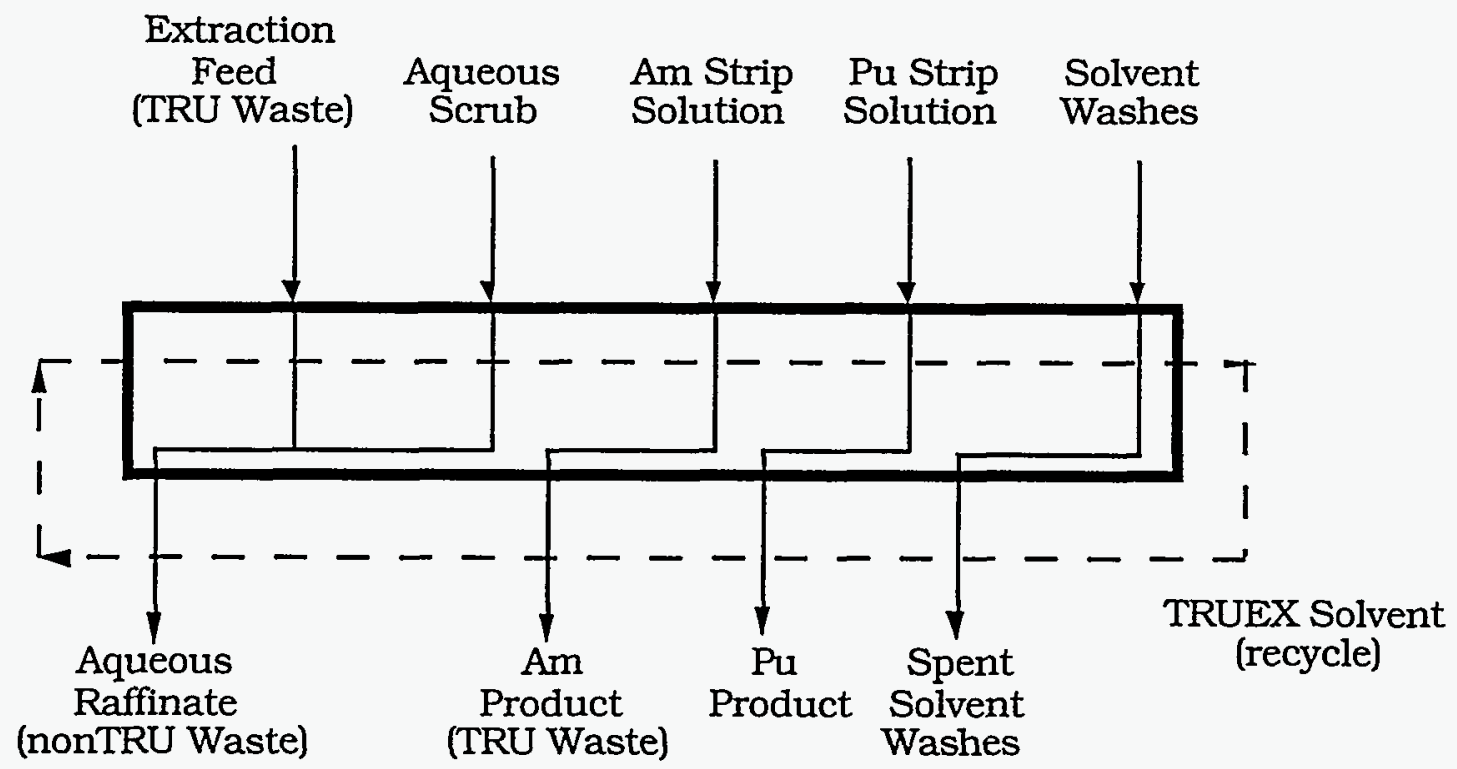

Fig. 2. Generic TRUEX Flowsheet

The ability of the TRUEX process to remove, separate, and recover TRU elements from aqueous nitrate or chloride media with a wide range of compositions makes it potentially a 
generic process for treating the entire range of high-level and TRU waste streams generated at DOE facilities. The application of a TRUEX process at these facilities would produce three important results:

1. Alleviate both long-term and short-term waste storage problems that threaten to curtail production

2. Reduce the volume of TRU waste generated by a processing plant by two orders of magnitude - the bulk of the waste thereby being nonTRU and a candidate for near-surface disposal

3. Recover plutonium that would otherwise be lost to waste disposal

The concentrations of TRU elements are generally low in the waste streams treated by TRUEX processing, so concentrating them can reap large benefits. LICON evaporators have two very significant advantages that make them strong candidates for concentrating radioactive waste streams: (1) high decontamination factors (DFs) can be achieved in the distillate and (2) solids can be handled easily. Effluent streams of a typical TRUEX process are discussed below in terms of the potential benefits and concerns of concentrating by evaporation. These same streams were shown previously in Fig. 2.

\section{Aqueous Raffinate}

This stream would contain extremely low concentrations of TRU elements $\left(\sim 10^{-10} \underline{\mathrm{M}}\right)$, low concentrations of fission products $\left(\sim 10^{-4} \underline{\mathrm{M}}\right)$, and high concentrations of nitric acid $(0.5-8 \underline{\mathrm{M}})$ and nitrate salts of sodium, aluminum, and iron $(0.1-1 \underline{\mathrm{M}})$. It is considered nonTRU. The distillate of this stream would be a nitric acid solution that would increase in nitric acid concentration (as the bottoms were concentrated) from essentially pure water to the azeotropic composition. The benefit of concentrating this stream by evaporation to near dryness is that the nitric acid would not need to be neutralized before being immobilized in grout. ${ }^{*}$ Nitric acid removal would typically decrease the waste volume by a factor of 2-20. On the other hand, the distillate solution would need . to be recycled in the plant; otherwise, this stream would just be one more low-level waste to be handled. A high DF from radioactive components would increase the potential uses of this nitric acid stream in the plant or may make its disposal economical. The fate of the concentrated bottoms must also be studied.

Because nitric acid is needed to acidify and redissolve the sludge in underground storage tanks, TRUEX processing of neutralized high-level waste would be greatly benefited by recovering and recycling nitric acid from the nonTRU raffinate. The distillate may also be appropriate for feed to the scrub section of the TRUEX process.

\section{2. $\quad$ Americium Product Stream}

The americium product is the effluent from the first strip section of the TRUEX process. In general, it is a dilute nitric acid solution (0.03-0.2M) containing nitrate salts of rare-earth fission products $\left(0-10^{-3} \underline{\mathrm{M}}\right)$, iron $\left(\sim 10^{-4} \underline{\mathrm{M}}\right)$, and americium $\left(10^{-10}-10^{-5} \underline{\mathrm{M}}\right)$. If plutonium were maintained in the III oxidation state, it would also be stripped into this waste stream. Because

\footnotetext{
* Neutralizing nitric acid with sodium hydroxide would greatly increase the amount of sodium nitrate and, thus, increase the mass of waste to be disposed of.
} 
this stream is so dilute in TRU content, it is a prime candidate for evaporation, especially when processing waste streams that do not contain high concentrations of rare-earth fission products. The bottoms should be concentrated by several orders of magnitude to produce an economic disposal package for the Waste Isolation Pilot Plant (WIPP), while the distillate could be recycled to the process to act as the incoming strip solution.

One potential problem is the heat generated by the concentrated waste streams. The heat generated by fission products may limit the degree of concentration that can be accomplished. The effect of this heat generation on evaporator operation was examined this year and found to be negligible compared to the heat needed to evaporate solutions. (See Sections III.E and III.F.) However, an analysis of the effect of concentration on the final waste form was not completed this year.

A high decontamination of the distillate from the salts in the product stream is essential to its reuse as a strip feed solution. Nitric acid would probably be added to the distillate to make up for that lost to the bottoms.

\section{Plutonium Product Stream}

The plutonium product stream is the effluent from the second strip section of the TRUEX process. (If the plutonium is not worth recovering, plutonium in the feed can be maintained in the III oxidation state, eliminating this strip.) In general, this stream is a solution of dilute nitric acid (0.02-0.05 $\mathrm{M}$ ) and an aqueous-phase complexing agent [e.g., $\mathrm{HF}, \mathrm{H}_{2} \mathrm{C}_{2} \mathrm{O}_{4}$, or $\left(\mathrm{NH}_{4}\right)_{2} \mathrm{C}_{2} \mathrm{O}_{4}$ ], with low concentrations $\left(10^{-4}-10^{-8} \mathrm{M}\right)$ of complexed iron, plutonium, and, in some cases, neptunium. Concentrating this stream before its recycle to an appropriate plutonium-recovery process would be very beneficial. The distillate could also be recycled to the TRUEX process as the feed to the second strip.

A high decontamination of the distillate is crucial to its use as the plutonium strip feed. The degree to which the aqueous-phase complexants partition to the distillate needs to be analyzed, and the effects of precipitating fluoride and oxalate salts of plutonium need to be determined. Criticality concerns are also an important issue.

\section{Spent Solvent Washes}

There will probably be at least two solvent washes for a typical TRUEX flowsheet: an aqueous-complexant wash to remove any TRU or fission-product species that are not removed from the solvent during stripping and a carbonate wash to remove water-soluble, acidic solvent-degradation products. These solutions are typically recycled through the process and are likely to have very dilute metal-ion concentrations. The solutions will be replaced periodically due to chemical breakdown. The distillate would essentially be water and the bottoms would probably be low-level waste. The amount of concentration of the bottoms could be substantial, but, because the volumes of these streams are low compared to those of raffinate and product streams, concentrating these streams may not be as consequential to the overall plant.

\section{Spent Solvent Acid Rinse}

An acid rinse of the solvent follows the solvent-wash steps. The feed to this section would be a dilute nitric acid solution $(\sim 0.1 \underline{\mathrm{M}})$. The effluent would be a nitric acid-sodium nitrate solution. (The sodium nitrate is formed from the neutralization of sodium carbonate that was 
entrained in the solvent exiting the previous solvent-wash section.) This stream would also be a relatively low-volume, low-level waste stream that would benefit from concentration. The distillate would be essentially pure water.

\section{Criticality Safety}

Nuclear criticality safety is achieved in one of three ways: geometry control, concentration control, or administrative control. Each of these control methods is reviewed here and its application to evaporator design discussed.

Geometry control is a single-parameter limit. Based on uniform aqueous solutions of fissile nuclides in a cylinder of infinite length, the subcritical limit for the cylinder diameter is $11.7 \mathrm{~cm}$ for ${ }^{233} \mathrm{U}, 14.4 \mathrm{~cm}$ for ${ }^{235} \mathrm{U}$, and $15.4 \mathrm{~cm}$ for ${ }^{239} \mathrm{Pu}$ [ANS]. Thus, in evaporators that will contain ${ }^{239} \mathrm{Pu}$, evaporator diameter should be limited to $15.2-\mathrm{cm}(6 \mathrm{in}$.) for all parts that could possibly fill up with liquid. For example, if LICON made a 6-in. evaporator, its throughput (given in terms of distillate output) is estimated to be $95 \mathrm{~L} / \mathrm{h}(25 \mathrm{GPH})$ for a single-effect unit. If a doubleeffect unit could be used, it would have roughly twice this throughput, higher throughputs would have to be handled by multiple units. These units would have to be positioned an estimated $12.7 \mathrm{~cm}$ (5 in.) apart [PAXTON]. The structural frame holding the 30-GPH evaporator is $107 \mathrm{~cm} \mathrm{(42} \mathrm{in.)}$ wide, so that the required spacing between units would be achieved with no special design changes.

Neutron absorbers such as cadmium or boron could be used in the evaporator structure or in the evaporator solution or both to increase the maximum allowable geometry control. However, because some fraction of them could end up in the concentrated waste from the evaporator and introduce new waste disposal problems, their use is not recommended.

Concentration control is also a single-parameter limit. Based on uniform aqueous solutions of fissile nuclides, the subcritical limit for the concentration of the fissile nuclide is $10.8 \mathrm{~g} / \mathrm{L}$ for ${ }^{233} \mathrm{U}, 11.6 \mathrm{~g} / \mathrm{L}$ for ${ }^{235} \mathrm{U}$, and $7.3 \mathrm{~g} / \mathrm{L}$ for ${ }^{239} \mathrm{Pu}$ [ANS]. For some solutions, such as the nonTRU aqueous raffinate from the TRUEX process, it may be possible to show that other salts present may prevent the subcritical concentration limit from being exceeded. (Note that, as a solution is evaporated to dryness, the subcritical concentration limit goes up since there is little or no hydrogen present to moderate the neutrons.) For such process streams, which are very low in fissile nuclides, concentration control may be an acceptable alternative to geometry control. When this is the case, a larger evaporator can be used, since geometry control would no longer be required for nuclear criticality safety.

Administrative control requires a much more active program to insure nuclear criticality safety. It is a multiparameter control program that can include either geometry or concentration controls at specific points in the process. At other points, it could include inventory control (subcritical limit for ${ }^{239} \mathrm{Pu}$ mass in a uniform aqueous solution is $0.48 \mathrm{~kg}$ ), slab-thickness control (subcritical limit for slab thickness with ${ }^{239} \mathrm{Pu}$ in an uniform aqueous solution is $5.5 \mathrm{~cm}$ ), and solution volume control (subcritical limit for solution volume with ${ }^{239} \mathrm{Pu}$ in a uniform aqueous solution is $7.3 \mathrm{~L}$ ) [ANS]. When administrative control is used, then procedural and operation controls have to be set up, reviewed, and implemented. While administrative control may include the use of geometry control for nuclear criticality safety in the evaporators, it does leave open other options to insure nuclear criticality safety in the evaporators. 


\section{Remote Operation and Maintenance}

Because the plant-scale evaporator must be located within a shielded cell or canyon, the evaporator must be remotely operable and maintainable. A literature survey was completed to gather information on designing equipment for remote operation and maintenance. The most extensive source of information found is a lengthy Oak Ridge Laboratory report by Burgess et al. [BURGESS]. Design guidelines for remotely operated equipment, as well as for the remote facility, remote manipulators, and remote viewing equipment, are given. Information on radiolytic degradation of selected materials is included, along with drawings of fasteners and connectors that have been developed for use in such applications.

A paper by Kring and Schrock [KRING], which deals with important lessons learned in a particular remote-maintenance facility is also notable. The paper mentions three major areas that need attention in designing remote equipment: replaceability, viewability, and accessibility. In short, equipment should be designed in modules which are easily replaced, and visual, as well as working, access must be maintained around each module.

\section{E. Self-Heating of TRU-Containing Solutions due to Alpha Decay}

High-energy alpha particles (5-6 MeV) released by the decay of neptunium, plutonium, and americium isotopes are completely adsorbed into solutions in which they are dissolved. This energy is converted directly into heat, which acts to raise the temperature of the solution and/or cause it to vaporize. Although this effect is minimal in the dilute concentrations typical of waste streams $\left(10^{-6}-10^{-5} \mathrm{M}\right)$, it should be taken into account as these streams are concentrated. Table 1 shows the factors used to convert concentrations of TRU elements to heatgeneration rates for specific isotopes.

Table 1. Conversion Factors Used to Calculate Heat Generation from Alpha Decay

\begin{tabular}{|c|c|c|c|c|c|c|c|c|c|}
\hline \multirow[b]{2}{*}{ Element } & \multirow[b]{2}{*}{ Isotope } & \multirow{2}{*}{$\begin{array}{c}\text { Half-life } \\
\text { Years }\end{array}$} & \multicolumn{2}{|c|}{ Specific Activity } & \multirow{2}{*}{$\begin{array}{c}\text { Decay Energy } \\
\text { MeV/dis }\end{array}$} & \multicolumn{4}{|c|}{ Specific Power } \\
\hline & & & $\mathrm{dps} / \mathrm{mol}$ & $\mathrm{dps} / \mathrm{g}$ & & $\mathrm{W} / \mathrm{mol}$ & W/g & $\mathrm{cal} / \mathrm{s}-\mathrm{mol}$ & $\mathrm{cal} / \mathrm{s}-\mathrm{g}$ \\
\hline $\mathrm{Np}$ & 237 & $2.14 \mathrm{E}+06$ & $6.18 \mathrm{E}+09$ & $2.61 \mathrm{E}+07$ & 4.96 & 4.91E-03 & 2.07E-05 & $1.17 \mathrm{E}-03$ & $4.95 \mathrm{E}-06$ \\
\hline \multirow[t]{3}{*}{$\mathrm{Pu}$} & 238 & $8.77 \mathrm{E}+01$ & $1.51 E+14$ & $6.34 \mathrm{E}+11$ & 5.59 & $1.35 E+02$ & $5.68 \mathrm{E}-01$ & $3.23 E+01$ & $1.36 \mathrm{E}-01$ \\
\hline & 239 & $2.44 E+04$ & $5.42 \mathrm{E}+11$ & $2.27 \mathrm{E}+09$ & 5.24 & $4.55 \mathrm{E}-01$ & $1.91 \mathrm{E}-03$ & $1.09 \mathrm{E}-01$ & 4.55E-04 \\
\hline & 240 & $6.58 \mathrm{E}+03$ & $2.01 E+12$ & $8.38 E+09$ & 5.26 & $1.69 E+00$ & $7.05 \mathrm{E}-03$ & 4.05E-01 & $1.69 \mathrm{E}-03$ \\
\hline $\mathrm{Am}$ & 241 & $4.58+02$ & $2.89 E+13$ & $1.20 \mathrm{E}+11$ & 5.64 & $2.61 E \div 01$ & $1.08 \mathrm{E}-01$ & $6.24 \mathrm{E}+00$ & $2.59 \mathrm{E}-02$ \\
\hline
\end{tabular}

Figure 3 displays the spreadsheet used to calculate heat generation in a solution containing user-specified concentrations of these isotopes as the solution is concentrated. The temperature rise is calculated based on all waste solutions having the specific heat of water; one calorie will raise the temperature of 1 gram of water $1^{\circ}$ centigrade. Figures 4 through 6 display examples of calculations made by this spreadsheet. Note that the effects of self-heating are not overwhelming for these solutions. In the case of ${ }^{241} \mathrm{Am}$, for example, a $1 \mathrm{M}$ solution will only generate $26 \mathrm{~W} / \mathrm{L}$. 


\begin{tabular}{|c|c|c|c|c|c|c|}
\hline \multirow[b]{3}{*}{$\begin{array}{l}\text { Usar cen } \\
\text { ehenge } \\
\text { these cone } \\
\text { and oflect } \\
\text { table below }\end{array}$} & \multicolumn{6}{|c|}{ Sproadshoot usod to Calculato Hoat Genoration in a Spocitic TRU-Containing Solution } \\
\hline & Isotopo & $\begin{array}{c}\text { Concentration } \\
\mathrm{mol} / \mathrm{L}\end{array}$ & Isolope & Wattsimol & 1solope & $\mathrm{cal} / \mathrm{s}-\mathrm{mol}$ \\
\hline & 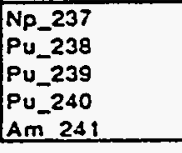 & $\begin{array}{l}0.00 E+00 \\
0.00 E+00 \\
0.00 E+00 \\
0.00 E+00 \\
1.00 E-06\end{array}$ & $\begin{array}{l}N \_W \\
P \_38 W \\
P \_39 W \\
P-40 W \\
P-W W \\
A-W\end{array}$ & $\begin{array}{l}4.91 E-03 \\
1.35 E+02 \\
4.55 E-01 \\
1.69 E+00 \\
2.61 E+01 \\
\end{array}$ & $\begin{array}{l}A-C \\
P-38 C \\
P-39 C \\
P-40 C \\
A C\end{array}$ & $\begin{array}{l}1.17 E-03 \\
3.23 E+01 \\
1.09 E-01 \\
4.05 E-01 \\
6.24 E+00\end{array}$ \\
\hline $\begin{array}{l}\text { Soln cone } \\
\text { tactor }\end{array}$ & $\begin{array}{l}\text { TAU Cone } \\
\text { molll }\end{array}$ & Walts/L & $(C a / L) / s$ & \begin{tabular}{|} 
Temperature \\
Rlse, OCimin
\end{tabular} & & \\
\hline $1.00 \mathrm{E}+00$ & $1.00 \mathrm{E}-06$ & $2.61 E-05$ & $6.24 E-06$ & $3.74 E \cdot 07$ & & \\
\hline $3.00 E+00$ & 3.00E.06 & 7.83E.05 & $1.87 E-05$ & $1.12 E-06$ & & \\
\hline $1.00 \mathrm{E}+01$ & $1.00 E \cdot 05$ & 2.61E-04 & 6.24E.05 & 3.74E-06 & & \\
\hline $2.00 E+01$ & $2.00 E \cdot 05$ & $5.22 E-04$ & $1.25 E \cdot 04$ & 7.49E-06 & & \\
\hline $3.00 E+01$ & $3.00 E \cdot 05$ & $7.83 E \cdot 04$ & $1.87 E \cdot 04$ & 1.12E-05 & & \\
\hline $5.00 E+01$ & 5.00E.05 & $1.30 E-03$ & 3.12E-04 & $1.87 E-05$ & & \\
\hline $1.00 E+02$ & $1.00 E .04$ & $2.61 E-03$ & $6.24 E-04$ & $3.74 \mathrm{E}-05$ & & \\
\hline $2.00 E+02$ & $2.00 E-04$ & $5.22 E-03$ & $1.25 \mathrm{E}-03$ & 7.49E-05 & & \\
\hline $3.00 E+02$ & $3.00 E-04$ & $7.83 E .03$ & $1.87 \mathrm{E} .03$ & $1.12 E-04$ & & \\
\hline $5.00 E+02$ & 5.00E-04 & $1.30 \mathrm{E} .02$ & $3.12 E-03$ & $1.87 \varepsilon-04$ & & \\
\hline $1.00 E+03$ & $1.00 E .03$ & $2.61 E .02$ & $6.24 E \cdot 03$ & $3.74 E-04$ & & \\
\hline $2.00 E+03$ & 2.00E.03 & $5.22 E-02$ & 1.25E-02 & $7.49 E-04$ & & \\
\hline $3.00 E+03$ & 3.00E-03 & 7.83E-02 & $1.87 E-02$ & $1.12 E-03$ & & \\
\hline $5.00 E+03$ & $5.00 E-03$ & $1.30 \mathrm{E}-01$ & 3.12E-02 & $1.87 \mathrm{E}-03$ & & \\
\hline $1.00 E+04$ & $1.00 E-02$ & 2.61E-01 & 6.24E-02 & $3.74 \mathrm{E} \cdot 03$ & & \\
\hline $2.00 E+04$ & 2.00E-02 & 5.22E-01 & $1.25 \mathrm{E}-01$ & 7.49E-03 & & \\
\hline $3.00 E+04$ & $3.00 E-02$ & $7.83 E-01$ & $1.87 E .01$ & $1.12 E-02$ & & \\
\hline $5.00 E+04$ & $5.00 E .02$ & $1.30 E+00$ & $3.12 E-01$ & $1.87 E-02$ & & \\
\hline $1.00 E+05$ & 1.00E-01 & $2.61 E+00$ & $6.24 E-01$ & $3.74 \mathrm{E} \cdot 02$ & & \\
\hline $2.00 E+05$ & $2.00 E-01$ & $5.22 E+00$ & $1.25 E+00$ & $7.49 E-02$ & & \\
\hline $3.00 E+05$ & 3.00E-01 & $7.83 E+\infty 00$ & $1.87 \varepsilon+00$ & $1.12 E-01$ & & \\
\hline $5.00 E+05$ & 5.00E-01 & $1.30 E+01$ & $3.12 E+00$ & $1.87 E-01$ & & \\
\hline $1.00 E+06$ & $1.00 E+00$ & $2.61 E+01$ & $624 E+00$ & $3.74 \mathrm{E} \cdot 01$ & & \\
\hline
\end{tabular}

- Assumes no evaporation

Fig. 3. Spreadsheet Used to Calculate Heat Generation in a Specific TRU-Containing Solution 


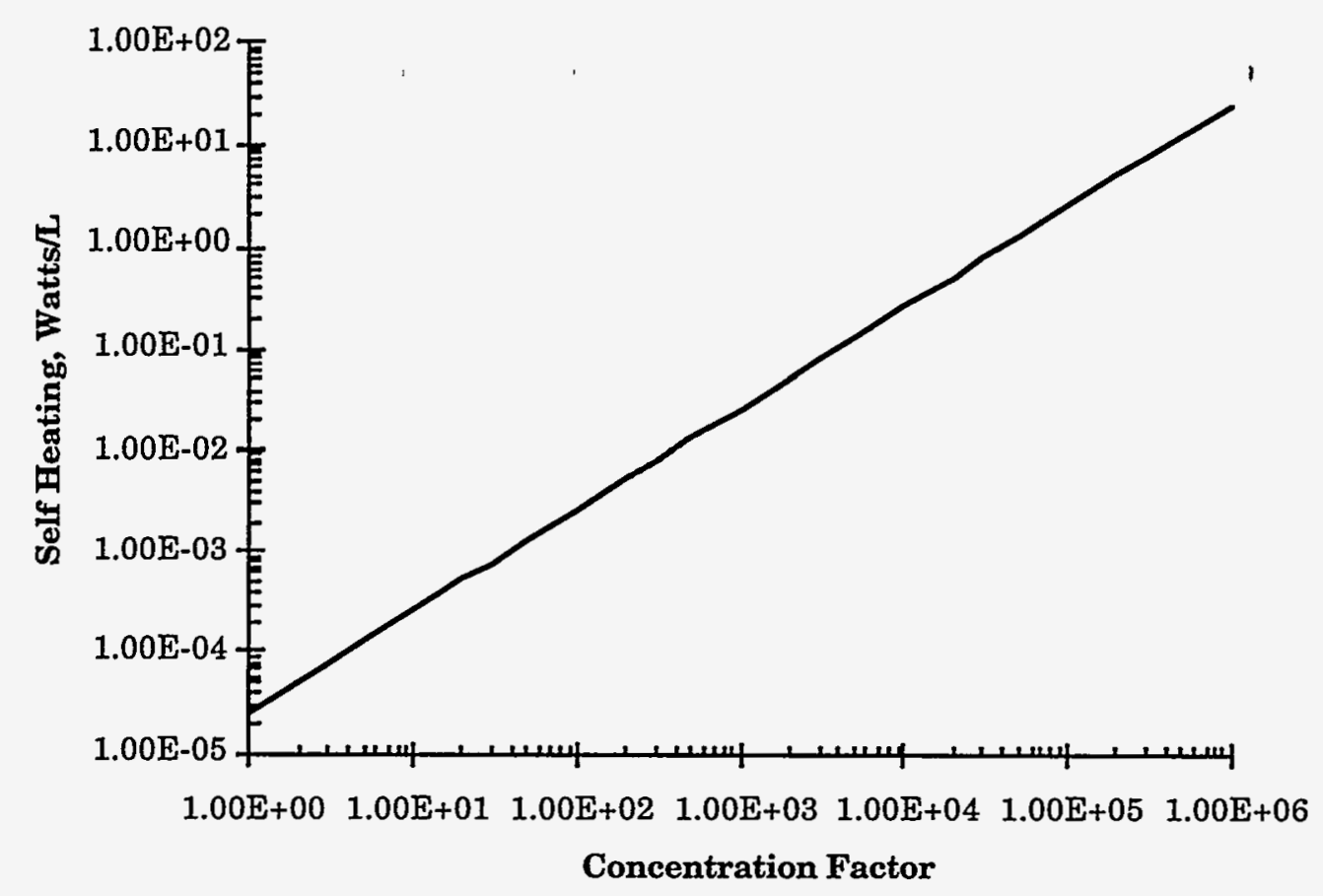

Fig. 4. Calculation of Self-Heating as a Solution Containing $10^{-6} \underline{\mathrm{M}}$ Am-241 Is Concentrated

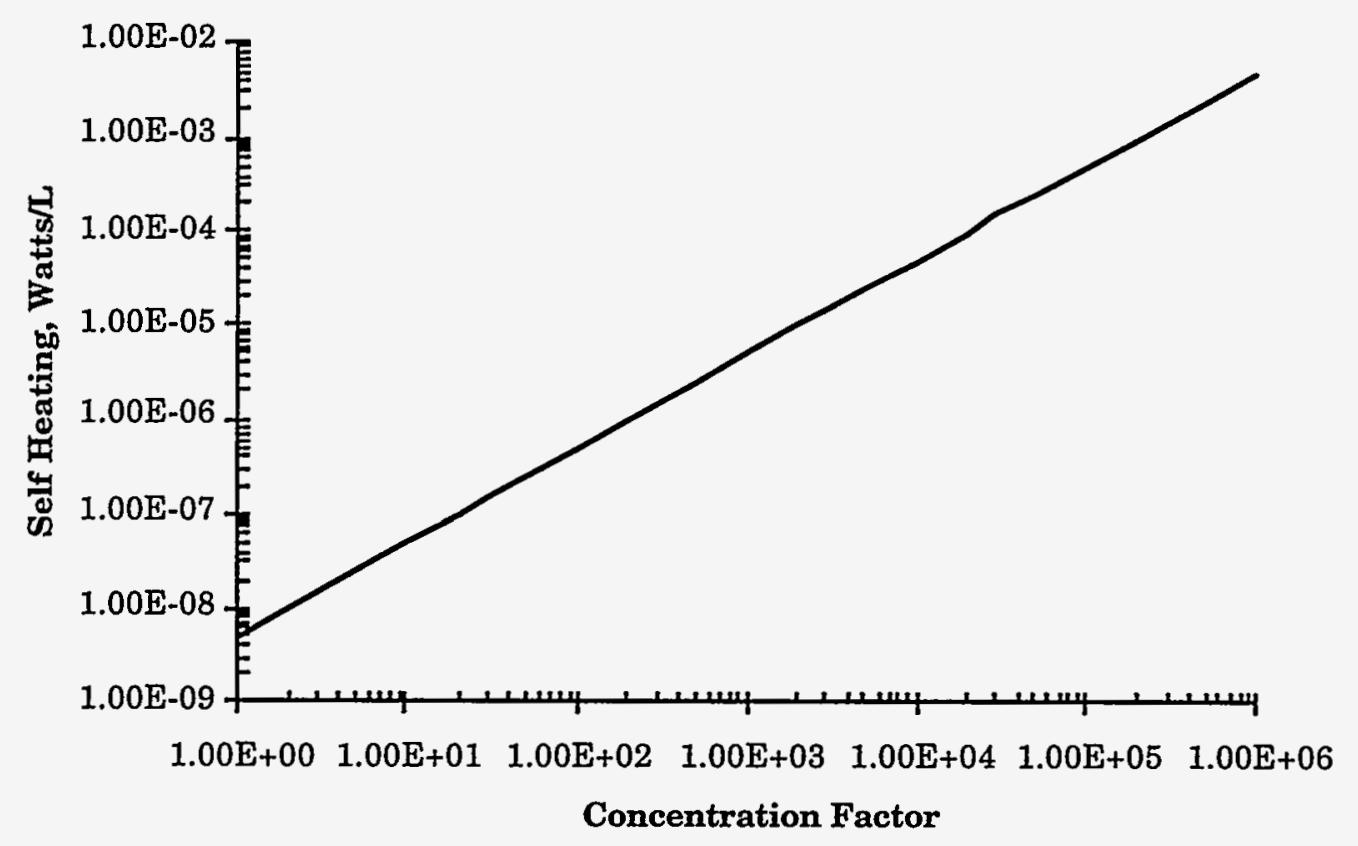

Fig. 5. Calculation of Self-Heating as a Solution Containing $10^{-7} \underline{\mathrm{M}} \mathrm{Np}-237$ Is Concentrated 


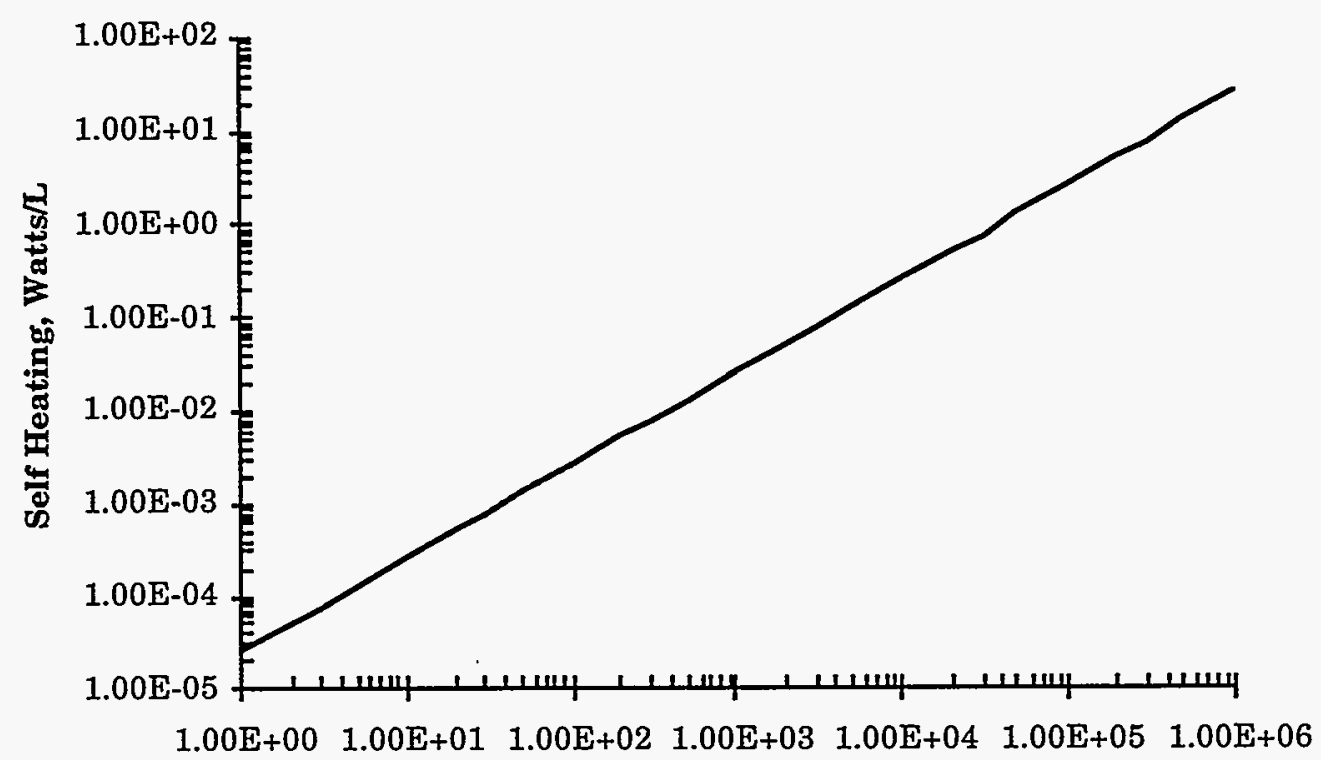

Concentration Factor

Fig. 6. Calculation of Self-Heating as a Plutonium Solution $\left(10^{-9} \underline{\mathrm{M}} \mathrm{Pu}-238\right.$, $10^{-6} \underline{\mathrm{M}} \mathrm{Pu}-239,7 \times 10^{-8} \underline{\mathrm{M}} \mathrm{Pu}-240$ ) Is Concentrated

\section{F. Self-Heating of Fission Product-Containing Solutions}

Based on ORIGEN2 calculations for typical 5000 MWD/MTIHM* PWR (Pressurized Water Reactor) Fuel [CROFF], PUREX raffinate would produce 88 and 55 W/MTIHM 30 and 50 years after discharge from the reactor, respectively. All but about 2 W/MTIHM are due to fission products, and essentially all of the fission-product heat production is due to the ${ }^{90} \mathrm{Sr}$ and ${ }^{137} \mathrm{Cs}$ and their short-lived daughters ${ }^{90} \mathrm{Y}$ and ${ }^{137} \mathrm{Ba}$. Approximately $50 \%$ of the heat production is due to the ${ }^{90} \mathrm{Sr} / 90 \mathrm{Y}$ pair and $50 \%$ to the ${ }^{137} \mathrm{Cs} /{ }^{137} \mathrm{Ba}$ pair.

To estimate heat production due to radioactive decay in a fission-product-containing waste, such as the nonTRU raffinate of a TRUEX process, the concentrations of fission products in solution were estimated [CHAMBERLAIN]. In this report, we estimated that approximately $7 \mathrm{~L}$ of TRUEX raffinate would be generated for every $\mathrm{kg}$ of uranium in the fuel. Therefore, for Cs- and Srcontaining nonTRU raffinate (50 years after discharge from the reactor), the raffinate solution would produce about $0.008 \mathrm{~W} / \mathrm{L}$. A solution containing only strontium (e.g., that derived from dissolving Hanford neutralized sludge) would produce $0.004 \mathrm{~W} / \mathrm{L}$. Because of the high salt content possible in that waste, concentrating by greater than 100 would probably not be possible without significant precipitation of solids. Therefore, self-heating caused by fission products would be less than $1 \mathrm{~W} / \mathrm{L}$ in the concentrated product.

\footnotetext{
* Megawatt-day/metric ton of initial heavy metal (uranium).
} 


\section{G. Corrosion Evaluation}

\section{Mechanism of Corrosion of Metals}

Corrosion is the destruction of a metal structure by an electrochemical reaction. In this type of reaction, the metal is oxidized, while some other species in contact with the corroding metal phase is reduced. Corrosion can take many different forms. If two dissimilar metals are in contact (i.e., copper with iron, cold-worked steel with an annealed steel, or even crystals of the same metal in contact with crystals of a different crystallographic orientation), an electrochemical cell can form, and corrosion will occur. Grain boundaries of single-phase metals can serve as anodes (corrode) simply because metal atoms at the surface are more easily oxidized than metal atoms in the grain interior. In such a case, the interior metal atoms become the cathode and are reduced. Due to the high surface area, fine-grained metals are more susceptible to corrosion than coarse-grained metals. Also, because of high dislocation density, a cold-worked metal has a higher tendency for corrosion then an annealed metal. Despite the tendency for corrosion, the high dislocation density does significantly increase the strength of the cold-worked metal. The common categories of electrochemical cells are given below.

Dissimilar Metal Cells. Whenever two dissimilar metals are in contact, the net thermodynamic corrosion reaction at standard conditions can be determined from the electrochemical potentials at standard conditions. Tables of standard electrochemical potentials are readily available. They are written for the corresponding cathodic (reduction) half-reactions $\mathrm{E}_{\text {cell }}^{\circ}=\mathrm{E}_{\text {cat }}^{\circ}-\mathrm{E}_{\mathrm{an}}^{\circ}$, where

$$
\begin{aligned}
& \mathrm{E}^{\circ} \text { cell }=\text { cell standard potential, } \mathrm{V} \\
& \mathrm{E}^{\circ} \text { cat }=\text { cathodic half-reaction standard potential, } \mathrm{V} \\
& \mathrm{E}^{\circ}{ }_{\text {an }}=\text { anodic half-reaction standard potential, } \mathrm{V}
\end{aligned}
$$

If $\mathrm{E}_{\text {cell }}^{\circ}$ is positive, the reaction occurs spontaneously in the direction written. Here, $\mathrm{E}_{\text {an }}^{\circ}$ is negative because it is written in the tables as a reduction reaction; the sign is reversed for the same reaction that is written as an oxidation reaction.

When two dissimilar metals are in a corrosive medium, such as a salt solution, nonequilibrium effects may control the corrosion reactions. To identify the corroding metal, a galvanic series can be tabulated. Galvanic series are usually listed from anodic to cathodic materials; thus, materials at the top of the list will preferentially corrode when in contact with materials at the bottom of the list. A galvanic series is very medium-specific, and the order on the list can change drastically if the medium is changed [RALLS].

Concentration Cells. These types of cells result from two identical metal electrodes in contact with solutions of different compositions. The equilibrium potentials can be calculated using the Nernst Equation. In a differential aeration cell, one electrode is exposed to a solution with a high dissolved-oxygen concentration, while the other electrode is exposed to an oxygen-depleted solution. In an alkaline-to-neutral solution, the following half-reaction can occur:

$$
\frac{1}{2} \mathrm{O}_{2}+\mathrm{H}_{2} \mathrm{O}+2 \mathrm{e}^{-} \leftrightarrow 2 \mathrm{OH}^{-}
$$


In an acid solution,

$$
2 \mathrm{H}^{+}+2 \mathrm{e}^{-} \leftrightarrow \mathrm{H}_{2}
$$

can occur, which can be coupled to the corrosion half-reaction:

$$
\mathrm{Fe} \leftrightarrow \mathrm{Fe}^{+2}+2 \mathrm{e}^{-}
$$

In a crevice, oxygen can be depleted, and the reaction given by Eq. 3 will readily occur in this anodic region if it can be electrically coupled with either of the preceding reactions (Eq. 1 or 2). In the . oxygen-poor region, at such locations as beneath a bolt head or behind an attached joint, reaction 3 causes extensive metal corrosion. Just outside the crevice, the oxygen concentration is high and reaction 1 occurs. Near the surface of liquid in contact with air, crevices are especially subject to this type of corrosion, as evidenced by corrosion of oil rigs and ships in regions close to the water line. Reactions following Eqs. 1-3 form the basis for a type of corrosion called crevice corrosion [RALLS, UHLIG].

Reaction 2 (Eq. 2) can be shifted to the right in the presence of dissolved oxygen due to Eq. 4 below.

$$
2 \mathrm{H}^{+}+\frac{1}{2} \mathrm{O}_{2}+2 \mathrm{e}^{-} \rightarrow \mathrm{H}_{2} \mathrm{O}
$$

The net result of Eqs. 4 and 3 is

$$
\mathrm{Fe}+\mathrm{H}_{2} \mathrm{O}+\frac{1}{2} \mathrm{O}_{2} \rightarrow \mathrm{Fe}(\mathrm{OH})_{2}
$$

When ferrous hydroxide $\left[\mathrm{Fe}(\mathrm{OH})_{2}\right]$ comes in contact with dissolved oxygen, ferric hydroxide $\left[\mathrm{Fe}(\mathrm{OH})_{3}\right]$ is formed.

$$
\mathrm{Fe}(\mathrm{OH})_{2}+\frac{1}{2} \mathrm{H}_{2} \mathrm{O}+\frac{1}{4} \mathrm{O}_{2} \rightarrow \mathrm{Fe}(\mathrm{OH})_{3}
$$

Ferric hydroxide, the main component in rust, is orange-to-red. Chlorides have been shown to catalyze the reaction of iron metal with wet air (Eq. 5) and accelerate the formation of rust (Eq. 6).

Temperature Cell. This type of corrosion results when a uniformcomposition metal is put in a uniform-composition solution, in which different areas of the metal are at different temperatures. This situation is very common in all types of heat-exchange equipment. In the case of copper in $\mathrm{CuSO}_{4}$, the copper is the cathode at the higher temperature; at the lower temperature, it is the anode and corrodes. For some metals such as silver, the reverse occurs and the hot end becomes the anode [UHLIG]. Iron in dilute sodium chloride solutions behaves similarly to copper, but, depending on conditions (time, stirring, aeration), the polarity can be reversed. The theoretical basis of temperature cells is not well understood at this time. 
In actual practice, the corrosion reactions that occur may not fit into one of these three categories perfectly, but these three mechanisms cover the known mechanisms of corrosion.

\section{Corrosion Testing}

Corrosion tests can take many forms. Several tests are discussed in the Chemical Engineer's Handbook [PERRY]. In the total-immersion test, a coupon of test material is submerged in the test solution for a precisely measured time period. The corrosion rate is determined from the weight loss of the specimen. The National Association of Corrosion Engineers has developed very extensive standards to test various types of materials. The standards describe the volume of the test reactors, the area of the test specimens, and the cleaning procedures, which utilize such solvents as acetone, alcohol, or carbon tetrachloride. Test procedures exist for testing materials under simulated heat transfer conditions, in which test specimens are exposed to controlled temperature gradients and a vapor-liquid interface. The results from such tests are very valuable in evaluating candidate materials.

Uniform corrosion rates can be measured quickly and accurately using commercial electrochemical polarization equipment (EG\&G or Gamry Instruments). Such tests determine the kinetic parameters in the Tafel Equation [NAGY], which allows the corrosion current to be determined and the corrosion rate to be directly calculated using Faraday's Law. This technique is very reliable and correlates extremely well with the long-term coupon testing discussed above. It is useful only for liquid-phase corrosion processes, not vapor-phase processes [MARTIN, MORRIS, EVANS, STERN, BABOIAN]. The technique can be used to discriminate mechanisms of corrosion, such as pitting due to the breakdown of passivity, other corrosion mechanisms, and even corrosion inhibition [KAESCHE].

\section{Corrosion-Resistant Materials in Nitric Acid Environments}

In general, metals and alloys that form passive oxide films are the most resistant to corrosion. For these passive materials, the anodic potential of the corroding metal reaches a critical value; beyond it, further increases cause rapidly decreasing currents due to the thin oxide film. If the polarization curve of the cathodic material in the solution crosses the anodic polarization curve in this region above the critical potential, a lower corrosion current, and, hence, a lower rate of corrosion will occur. The polarization curve can be measured experimentally in a modified electrochemical cell [UHLIG]. Candidate materials and their corrosion resistance in nitric acid solutions are discussed in detail in a standard corrosion handbook [CRAIG]. A summary of what is contained in the corrosion handbook is given below.

Aluminum. At high acid concentrations (above 95\%) and low temperatures (below $40^{\circ} \mathrm{C}$ ), aluminum is superior to 304 stainless steel. At acid concentrations of about $20 \%$ and room temperature, the maximum rate of corrosion occurs. Nitrogen oxides accelerate the corrosion of aluminum. In the presence of nitrogen oxides, both agitation and increased temperature also accelerate corrosion.

Cast iron. Application of this material is limited to low-temperature, lowvelocity service; dilute acids corrode this material very rapidly and must be avoided.

Stainless steels. Austenitic stainless steels are very corrosion-resistant in nitric acid environments, especially if they are solution annealed. Addition of molybdenum increases 
corrosion, so that $316 \mathrm{~L}$ is inferior to $304 \mathrm{~L}$. (This result contradicts earlier references [YAMOMOTO, SCHREIBER]). Cast-equivalent stainless steels are inferior to wrought types, since the castings have high carbide contents at grain boundaries, which can lead to intergranular corrosion. Similarly, welding can lead to corrosion sites due to the precipitation of chromium carbides at grain boundaries (causing depletion of chromium in the iron matrix). Thus, type $304 \mathrm{~L}$ is superior to type 304 due to the reduced carbon content. Corrosion of stainless steel leads to the formation of $\mathrm{Cr}(\mathrm{VI})$, which increases the rate of corrosion; thus, purging the evaporator of the concentrated product solutions will extend the service life of the equipment. Corrosion rate data is shown in Table 2.

Table 2. Corrosion Data for Steels in Nitric Acid Solutions

\begin{tabular}{lccc}
\hline Material & $\begin{array}{c}\text { Acid Conc., } \\
\text { wt\% }\end{array}$ & $\begin{array}{c}\text { Temperature, } \\
{ }^{\circ} \mathrm{C}\end{array}$ & $\begin{array}{c}\text { Corrosion Rate, } \\
\mathrm{mm} / \mathrm{yr}\end{array}$ \\
\hline Carbon Steel & 25 & Boiling & 152 \\
304 SS & 20 & 93 & 0.027 \\
304 SS & 25 & Boiling & 0.6 \\
304 SS & 40 & Boiling & 0.06 \\
304 SS & 100 & Boiling & very high \\
304L SS & 65 & Boiling & 0.24 \\
316 SS & 100 & Boiling & very high \\
\hline
\end{tabular}

Types 316 and $316 \mathrm{~L}$ stainless steels are more resistant to corrosion than 304 and 304L SS in a high-salt/high-chloride environment (such as seawater). However, in a nitric acid environment by itself, $304 \mathrm{SS}$ is superior, as documented in the literature [CRAIG]. An experimental study must be made to determine which material is superior for the evaporator material.

The effect of temperature on the corrosion rates of an annealed 304 SS in nitric acid has been shown [CRAIG]. Increases in the temperature increase the corrosion rate by a factor of 5 or more for each $10^{\circ} \mathrm{C}$ increase at moderate $\left(<200^{\circ} \mathrm{F}\right)$ temperatures. In addition, the corrosion rate is found to generally increase with increasing nitric acid concentration.

A study was completed at Los Alamos National Laboratory on the corrosion of 316 SS simulated evaporator components [SCHREIBER]. The feed to the experimental $316 \mathrm{SS}$ cans contained the species listed in Table 3 , along with $6 \underline{\mathrm{M}}$ nitric acid and various concentrations of $\mathrm{Cl}^{-}$(added as 12M HCl).

Table 3. Simulated Evaporator Solution used in Los Alamos Evaporator Studya

\begin{tabular}{lcc}
\hline Element & Concentration, $\underline{\underline{M}}$ & Salt Used \\
\hline $\mathrm{Al}$ & 0.013 & $\mathrm{Al}\left(\mathrm{NO}_{3}\right)_{3} \cdot 9 \mathrm{H}_{2} \mathrm{O}$ \\
$\mathrm{Ca}$ & 0.020 & $\mathrm{Ca}\left(\mathrm{NO}_{3}\right)_{2} \cdot 4 \mathrm{H}_{2} \mathrm{O}$ \\
$\mathrm{Mg}$ & 0.015 & $\mathrm{Mg}\left(\mathrm{NO}_{3}\right)_{2} \cdot 6 \mathrm{H}_{2} \mathrm{O}$ \\
$\mathrm{K}$ & 0.025 & $\mathrm{KNO}_{3}$ \\
$\mathrm{Na}$ & 0.100 & $\mathrm{NaNO}_{3}$ \\
$\mathrm{Fe}$ & 0.037 & $\mathrm{Fe}\left(\mathrm{NO}_{3}\right)_{3} \cdot 9 \mathrm{H}_{2} \mathrm{O}$ \\
\hline
\end{tabular}

a[SCHREIBER] 
Schreiber found the following:

- Increases in $\mathrm{Fe}^{3+}$ concentration increase the rate of corrosion due to the reduction of $\mathrm{Fe}^{3+}$ by the metallic iron.

- The presence of $\mathrm{Cl}^{-}$enhances the reduction of $\mathrm{Fe}^{3+}$, thus increasing the corrosion rate.

- The presence of $\mathrm{NO}_{3}{ }^{-}$(added as $\mathrm{NaNO}_{3}$ ) inhibits the corrosion reactions, even with both $\mathrm{Cl}^{-}$and $\mathrm{Fe}^{3+}$ present (Table 4). It was speculated that nitrate either reduced the corrosion potential or interfered with the surface penetration of $\mathrm{Cl}^{-}$through the passive oxide film.

Table 4. Effect of $\mathrm{NO}_{3}{ }^{-}$on the Corrosion of $316 \mathrm{SS}$ at $120^{\circ} \mathrm{C}^{\mathrm{a}}$

\begin{tabular}{ccccc}
\hline Vessel No. & $\mathrm{Cl}^{-}, \underline{\mathrm{M}}$ & $\mathrm{Fe}^{+3}, \underline{\mathrm{M}}$ & $\mathrm{NO}_{3}, \underline{\mathrm{M}}$ & $\begin{array}{c}\text { Corrosion Rate, } \\
\mathrm{mm} / \mathrm{yr}\end{array}$ \\
\hline 4 & 0.10 & 0.10 & 0.00 & 0.056 \\
2 & 0.10 & 0.10 & 0.30 & $\mathrm{~b}$ \\
5 & 0.10 & 0.20 & 0.00 & 0.049 \\
6 & 0.10 & 0.40 & 0.00 & 0.086 \\
3 & 0.10 & 0.40 & 1.20 & 0.014 \\
\hline \\
a[SCHREIBER] \\
'Sample gained weight; therefore, corrosion rate could not be measured.
\end{tabular}

Copper. Copper corrodes readily in nitric acid.

Molybdenum. Molybdenum corrodes readily in nitric acid.

Nickel. Nickel and high-nickel-content alloys are generally inferior to stainless steel in nitric acid environments.

Titanium. Below $80^{\circ} \mathrm{C}$ titanium is superior to stainless steels. In hot or very pure solutions of nitric acid $\left(25 \%\right.$ or more nitric acid, $\left.100^{\circ} \mathrm{C}\right)$, significant rates of uniform corrosion will occur $(0.15+\mathrm{mm} / \mathrm{yr})$. For evaporation purposes, data indicate that titanium is superior to stainless steel. As titanium corrodes, certain dissolved species such as $\mathrm{Si}(\mathrm{IV}), \mathrm{Cr}$ (VI), $\mathrm{Fe}$ (III), and Ti(IV) will inhibit corrosion. Thus, purging the evaporator will accelerate the corrosion process.

The effect of temperature on the corrosion of titanium in nitric acid has been shown [CRAIG]. Again, the rate of corrosion is found in general to increase with temperature. However, unlike the case with the annealed 304 SS discussed previously, the maximum rate of corrosion occurs when the concentration of the nitric acid solution is about $50 \%$. At both higher and lower acid concentrations, the corrosion rate of titanium is lower.

Zirconium. This material is extremely resistant to corrosion in nitric acid solutions and is superior to stainless steels for this application. Even in boiling nitric acid (30-70\%) with high salt contents and chlorides, corrosion rates were well under $0.025 \mathrm{~mm} / \mathrm{yr}$. Zirconium is subject to pitting corrosion due to $\mathrm{Cl}^{-}$, but the presence of $\mathrm{NO}_{3}{ }^{-}$inhibits it (best at ratios of $\mathrm{NO}_{3}-\mathrm{Cl}^{-}$of 1 and 5). Stress-corrosion cracking can occur in loaded zirconium elements that are close to the yield point, but it should not be a problem in evaporators. 
4. DOE Experience with 304 SS in Nuclear Fuel Reprocessing and Waste Handling

Since the earliest forms of nuclear wastes generated in the United States were routinely handled in type 304 SS vessels, there is extensive experience using this material. A study was completed in 1983 on types 304L, 348, and unwelded type 304 waste storage tanks at the Idaho Chemical Processing Plant (ICPP). The wastes consisted of the following:

- Low-acid aluminum first-cycle extraction wastes

- Second- and third-cycle extraction waste with concentrated low-level waste

- Aluminum-zirconium first-cycle extraction wastes

- Stainless steel-nitrate first-cycle waste

- Stainless steel-sulfate extraction waste

- Miscellaneous reprocessing wastes

These storage tanks are cooled to $50^{\circ} \mathrm{C}$ to minimize corrosion. The wastes had various compositions of fission products and dissolved cladding, which have been documented [HOFFMAN]. The wastes have been stored for periods up to 30 years. Corrosion rates of these tanks were found to be minimal: an average rate of $3.6 \times 10^{-4} \mathrm{~mm} / \mathrm{yr}(0.014 \mathrm{mil} / \mathrm{y})$. The study concluded that the tanks were handling the wastes well, and a very long service life is expected.

Evaporation of PUREX waste at ICPP was done using primarily $304 \mathrm{~L}$ equipment. A detailed discussion of the heat treatment and welding procedures to construct this heattransfer equipment has been published [WILDING]. This report thoroughly summarizes all the corrosion research completed between 1947-1975 for this type of evaporation/waste treatment. Very specific solution-annealing temperatures and time schedules are discussed. The best heat-treatment procedures for several different composition wastes are discussed. In addition to this work, a thorough discussion of type $304 \mathrm{~L}$ corrosion in nitric acid-hydrofluoric acid solutions is available in another published report [COLE]. In this work, the following conclusions were made:

- Type 304L SS is the most suitable material for fully complexed ICPP nitrate-fluoride solutions.

- Annealing the stainless steels will improve corrosion resistance.

- Stabilization with niobium or titanium will improve corrosion resistance.

- If neutron-absorbing elements are required for criticality purposes, their percentages should be as low as possible since these elements lower corrosion resistance.

- Complexing the nitrate-fluoride solutions with aluminum, zirconium, or thorium will mitigate corrosion.

- The corrosion rate was found to directly correlate to the amount of uncomplexed hydrofluoric acid present.

Despite all this work with 304L SS, the corrosion and failure of heat-transfer equipment in the evaporation of nitric acid reprocessing solutions have been a continuing problem. 
A study was completed in 1980 on a small-scale thermosiphon evaporator using simulated PUREX waste [VILLEMEZ]. In this study, 304L was compared to Nitronic 50, Sandvik 2R12, and titanium. It was found that titanium was the best material for this application. Submerged, vapor space, heattransfer surfaces, and velocity effects were evaluated. Corrosion products, chloride levels, scaling, and heat transfer were measured. The most recent work on corrosion at ICPP for this application indicated that Hastelloy G30 is currently thought to be the most durable alloy for nitric acid waste service [MIZIA]. This work is ongoing, and most of it has not been published at this time. Selecting the appropriate construction material for a full-scale evaporator should be based on the most up-todate research available; the current work in progress at ICPP should be used as a guide. The exact material specification will require an accurate analysis of the composition of the waste to be evaporated. Type 304L may be appropriate, but the newest exotic alloys available should not be overlooked.

\section{LABORATORY-SCALE EVAPORATOR}

\section{A. Introduction}

A laboratory-scale evaporator was purchased from LICON and delivered to Argonne in July, 1992. Installation and connection of utilities was completed in early August, but some modifications to the system are still underway. The evaporator, a LICON FRIDGEVAP model FVP-C3, is a single-effect, horizontal-tube, vacuum-atmosphere evaporator with a distillate output of about $11.5 \mathrm{~L} / \mathrm{hr}(3 \mathrm{GPH})$.

The evaporator will be useful in verifying materials compatibility, gathering data on the evaporation process, assessing solids handling and maintenance needs, and gaining operating experience. This knowledge will aid in the eventual design of pilot plant- and plant-scale evaporators. Most experimental work using this laboratory-scale evaporator will involve evaporating liquid from solutions containing high concentrations of salts and acids. Data collected from these tests will be compared to literature and laboratory data.

\section{B. Basic Operation of a FRIDGEVAP Evaporator}

A flow diagram for a single-effect FRIDGEVAP with auxiliary electric heaters is shown in Fig. 7. The city water in the heating loop is heated by the heat pump and/or electric heaters. The heat pump is the standard heat source for the FRIDGEVAP. However, for applications requiring higher evaporation temperatures, the electric heaters are necessary. The hot water is pumped to the evaporator shell's water box and enters the bayonet-tube heat exchangers. The bayonet-tube heat exchanger consists of an inner tube enveloped in a slightly larger diameter outer tube. The hot water flows down the inner tube and returns to the water box through the outer tube. The small area between the two tubes enhances heat transfer across the outer tube wall to the concentrate. From the water box, the cooled heating water returns to the heaters.

Liquid that evaporates from the heated concentrate passes up through the vapor uptakes into the separator shell, past the demisters, and into the condenser shell. Any liquid entrained in the vapor phase coalesces on the demister pads and drops to the bottom of the separator. The concentrate pump extracts liquid from both the separator and evaporator shells and returns it to the concentrate tank. Feed is drawn from the concentrate tank to the evaporator by vacuum. The concentrate pump recycles the concentrate in the evaporator shell at a rate about ten times the vaporization rate. This recycling enhances heat transfer and reduces problems due to solids formation in the concentrate. 


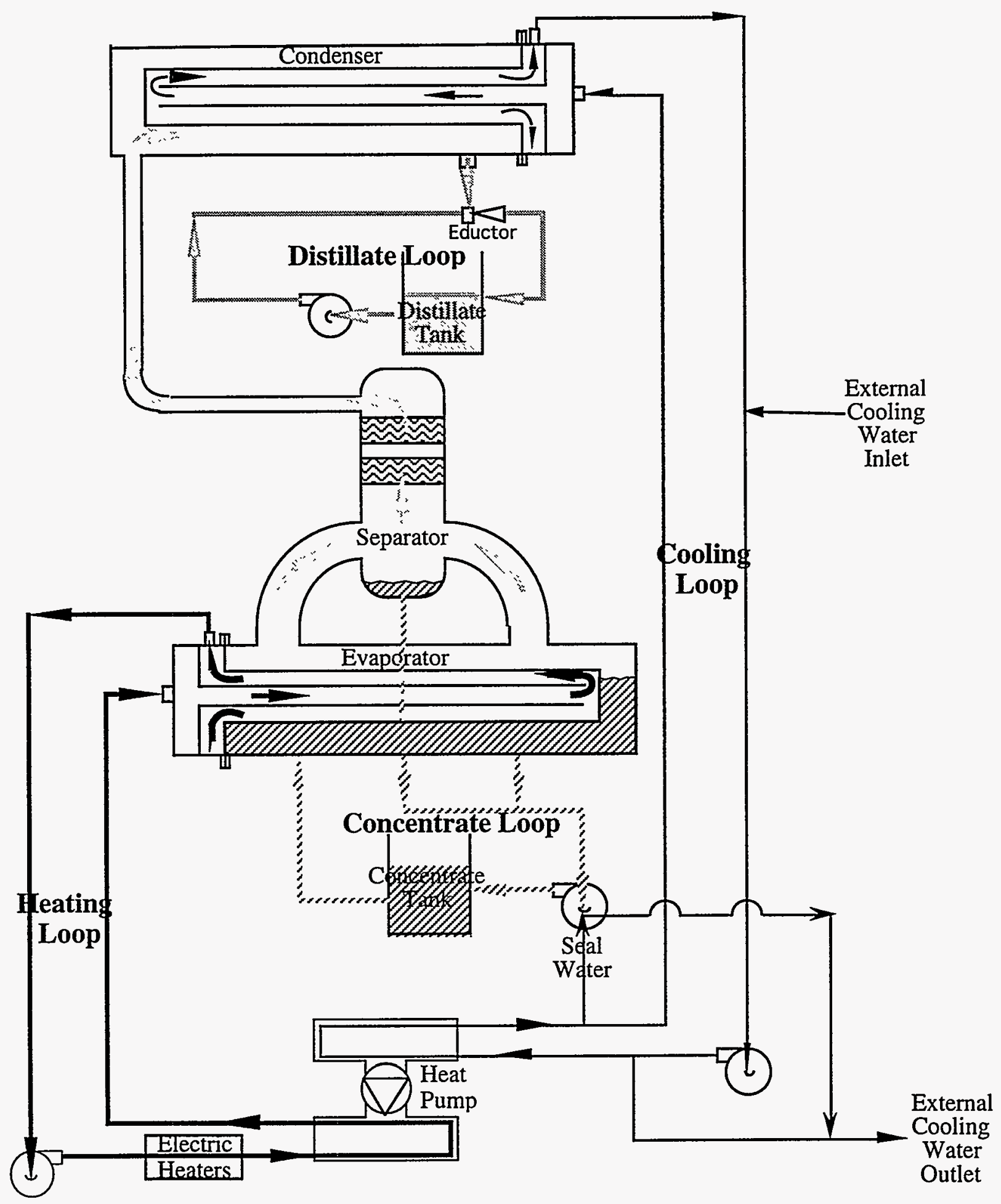

Fig. 7. Flow Diagram for a FRIDGEVAP Evaporator 
In the condenser shell, the vapor condenses on the exterior of the bayonet-tube heat exchanger. This liquid distillate, along with any noncondensable vapors, is drawn by vacuum into the hydraulic-jet eductor. The eductor is driven by the distillate pump, which circulates distillate from the distillate tank through the eductor and back to the tank. Besides drawing the distillate from the condenser shell, the eductor also creates a vacuum in the condenser, separator, and evaporator shells. This vacuum allows lower operating temperatures to be used than if the system operated at atmospheric pressure. Low operating temperatures are important in the evaporation process because they (1) decrease scaling problems on the evaporator tubes, (2) allow the use of lower-cost construction materials (such as polyvinyl chloride (PVC) and chlorinated polyvinyl chloride (CPVC)), and (3) decrease thermal degradation of heat-sensitive chemicals.

The cooling loop cools the condenser's bayonet-tube heat exchangers using city water. When the heat pump supplies the heat, it also provides most of the cooling for the cooling water, with the balance provided by the external cooling water flow. When the electric heaters are used, all cooling is provided by the external cooling water.

\section{Equipment Description}

The general specifications for Argonne's FVP-C3 are summarized in Table 5.

Table 5. General Specifications for FRIDGEVAP FVP-C3

\begin{tabular}{|c|c|}
\hline Overall Dimensions: & $81 \mathrm{~cm} \mathrm{~W} \mathrm{x} 168 \mathrm{~cm} \mathrm{~L} \times 188 \mathrm{~cm} \mathrm{H}(32 \mathrm{in.} \times 66$ in. $\times 74 \mathrm{in.})$ \\
\hline Estimated Dry Weight: & $544 \mathrm{~kg}(1200 \mathrm{lb})$ \\
\hline Electrical Connection Required: & $208 \mathrm{~V} / 1$ phase/60 cycle, $11,000 \mathrm{VA}$ maximum \\
\hline Cooling Water Required: & $9.5 \mathrm{~L} / \mathrm{min}(2.5 \mathrm{GPM})$ maximum \\
\hline Heat Pump Medium: & FREON 22. \\
\hline Heat Pump Heating Capacity: & $8.8 \mathrm{~kW}(30,000 \mathrm{BTU} / \mathrm{hr})$ \\
\hline Electric Heater Capacity: & $\begin{array}{l}5.5 \mathrm{~kW}(18,800 \mathrm{BTU} / \mathrm{hr}) \text { each, } \\
16.5 \mathrm{~kW}(56,300 \mathrm{BTU} / \mathrm{hr}) \text { total }\end{array}$ \\
\hline $\begin{array}{l}\text { Evaporator And Condenser } \\
\text { Heat-Exchanger Tube Bundles: }\end{array}$ & Three $2.54 \mathrm{~cm}$ ( 1 in.) OD Titanium tubes \\
\hline Concentrate Tank Volume: & $28.4 \mathrm{~L}(7.5 \mathrm{gal})$ \\
\hline Distillate Tank Volume: & $28.4 \mathrm{~L}(7.5 \mathrm{gal})$ \\
\hline Evaporate And Condenser Shells: & $\begin{array}{l}7.6 \mathrm{~cm} \text { dia. Schedule } 80 \mathrm{CPVC} \text { tubing, } 1 \mathrm{~m} \text { long } \\
(3 \mathrm{in.} \times 40 \text { in.) }\end{array}$ \\
\hline Separator Shells: & $\begin{array}{l}7.6 \mathrm{~cm}(3 \mathrm{in} .) \text { dia. Schedule } 80 \text { CPVC } \\
10.2 \mathrm{~cm} \text { ( } 4 \text { in.) dia. Schedule } 80 \text { CPVC } \\
15.2 \mathrm{~cm} \text { ( } 6 \text { in.) dia. Schedule } 80 \text { CPVC }\end{array}$ \\
\hline Vapor Uptakes: & Twin $5.1 \mathrm{~cm} \mathrm{(2} \mathrm{in.)} \mathrm{dia.} \mathrm{Schedule} 80 \mathrm{CPVC}$ tubes \\
\hline Evaporator And Condenser Pressure: & $100 \mathrm{mmHg}$ (2 psia) \\
\hline
\end{tabular}

Because the system operates under a vacuum ( $100 \mathrm{mmHg}$ absolute pressure), water will boil at temperatures below $43^{\circ} \mathrm{C}\left(110^{\circ} \mathrm{F}\right)$. The evaporation and condenser sections will normally run at approximately $60-80^{\circ} \mathrm{C}\left(140-175^{\circ} \mathrm{F}\right)$ and $38-60^{\circ} \mathrm{C}\left(100-140^{\circ} \mathrm{F}\right)$, respectively. The electric heaters will be used more than the heat pump because of the higher boiling points foreseen when using a high-salt feed. The heat pump can provide evaporation temperatures no higher than about $60^{\circ} \mathrm{C}\left(140^{\circ} \mathrm{F}\right)$. 
The evaporation process is controlled mainly by varying the heating-water temperature, the cooling-water flow rate, and the feed flow rate. The electronic controller for the electric heaters allows thermostatic control of the heating water. Because the heat pump is not thermostatically controlled, the cooling-water flow rate is the main control parameter when the heat pump is the sole source of heat.

The conductivity of the distillate is monitored by an analyzer with an analog gauge. It has an adjustable alarm that, when tripped (i.e., when the conductivity of the distillate is above the alarm setting), dumps the distillate back to the concentrate tank. If conductivity is not an accurate indication of the purity of the distillate (e.g., when acids are being recovered in the distillate), the analyzer can be disabled.

Distillate is automatically pumped out of the distillate tank when the liquid level in the tank rises high enough to trip a float in the tank. Depending on the alarm condition set by the conductivity analyzer, this distillate is sent back to the concentrate tank or to an external container. Concentrate product can be drawn off at any time during the process by opening a valve at the output side of the concentrate pump. The possibility of automating this effluent stream by either (1) drawing it off at a constant flow rate or (2) drawing off an aliquot at an established time interval is being evaluated.

Sensors for important operational and process parameters are built into the evaporator's equipment. Thermocouples are included to measure the temperature of these process streams: distillate, concentrate recycle, evaporator feed, and separator vapor. Thermocouples also monitor temperatures of the following operational streams: heating water into and out of the evaporator's water box, cooling water into and out of the condenser's water box, and heating water in the electric-heater tank.

Pressure gauges monitor the separator vacuum, the four pump output pressures, the double-mechanical-seal line pressure, and the heat pump compressor's high- and low-side pressures. A flow meter is in place on each of the following lines: evaporator feed, external cooling water inlet, cooling loop, and heating loop.

A sampling valve is located at the output of the concentrate pump so samples may taken of the concentrate leaving the evaporator shell before it mixes with the rest of the concentrate in the concentrate tank. Another sampling system allows the distillate leaving the condenser to be sampled before it mixes with the rest of the distillate in the distillate collection tank. Drain valves on the concentrate and distillate tanks allow sampling during operation.

Three separator shells were purchased with the evaporator to allow variation of the area available to flow of the vapor phase from the evaporator shell to the condenser shell. Little experimental data is available regarding the effect of this parameter on the evaporation process. The demister pads in each of the separators consist of two packs of mesh: a fiber mesh located directly below a stainless steel wire mesh. Demister pads for the three separators are identical, except for their diameters.

Major plumbing components of the FVP-C3 are constructed of Schedule 80 PVC and CPVC tubing, the high-temperature sections being CPVC. Softening of PVC and CVPC begins . around $60^{\circ} \mathrm{C}\left(140^{\circ} \mathrm{F}\right)$ and $93^{\circ} \mathrm{C}\left(200^{\circ} \mathrm{F}\right)$, respectively. A limit switch is built into the system to shut the system down if the temperature in the evaporator section (made of $\mathrm{CPVC}$ ) exceeds $82^{\circ} \mathrm{C}\left(180^{\circ} \mathrm{F}\right)$. 
Thus, significant softening of the PVC and CPVC piping due to high temperatures will not be a problem.

Besides the automatic shutdown system for high temperatures, four other automatic shutdown systems are incorporated into the evaporator. They guard against (1) loss of distillate pressure, which would stop the eductor from draining the condenser and from maintaining system vacuum, (2) loss of cooling water flow through the double mechanical seal in the concentrate pump, which would lead to seal failure and leakage of concentrate solution, (3) lack of sufficient concentrate level in the concentrate tank, which would eventually lead to running the evaporator shell dry, and (4) liquid flooding of the evaporator and separator shells, which would lead to contamination of the distillate.

The evaporator sits inside a stainless steel pan that rests on a weight-distribution pad. The pan forms a secondary container for the evaporator and is able to hold the total liquid contents of the evaporator and tanks (about $75 \mathrm{~L}$ total) should a major leak occur. The weight-distribution pad was necessary because the weight of the evaporator exceeded the loading limit of the laboratory floor.

The evaporator's equipment has been modified since it was delivered. All dial thermometers were replaced with thermocouples for more accurate temperature measurement and easier data collection. Considerable shielding was added to the evaporator to protect the piping from damage and experimenters from spraying chemicals if a leak occurs. Plexiglas panels have been fabricated to enclose the bottom section of the evaporator and shield the piping contained within that section. Pressurized piping above this bottom section that will carry salt or acid solutions has been shielded using various materials.

Because acids will eventually be used as feeds, key parts of the evaporator must be enclosed in a ventilation hood. We expect to use feeds containing mixtures of nitric, phosphoric, sulfuric, oxalic, and possibly hydrofluoric acids. Acids in the separator and condenser shells (as distillate) are anticipated. Under normal operation the evaporator, separator, and condenser sections, which will contain the acids, are not open to the atmosphere. Maintenance and design-change operations, however, will require disassembly of these sections at key points. Most importantly, the heat-exchanger tube bundles in both the evaporator and condenser shells will need to be pulled out occasionally. These bundles are pulled out with the water boxes, that is, with the headers that feed the heating and cooling water to the tube bundles. (See Fig. 8.) Therefore, the fittings at which these water boxes connect to the respective shells must be contained within a ventilation hood. Also, acid fumes due to vaporization from the concentrate and distillate tanks, which must be vented to atmospheric pressure, necessitate a ventilation hood.

To ensure enough working space around the water boxes to unfasten and pull out the tube bundles, a Vac-Frame hood was modified to incorporate the water boxes within the hood. Because plumbing complexities necessitated joining the hood with the evaporator, LICON added an end plate for the hood into the evaporator plumbing, as shown in Fig. 8.

A stainless steel drip pan in the hood will contain any spillage that occurs there. The hood is vented into the building's ventilation system. Because acid fumes could be carried into the ventilation system, adsorptive filters were purchased to remove them from the air stream. A filter housing to hold these filters is being designed. The fumes must be removed before they enter the building's duct work. Not only is part of the duct work aluminum, but also acid fumes 


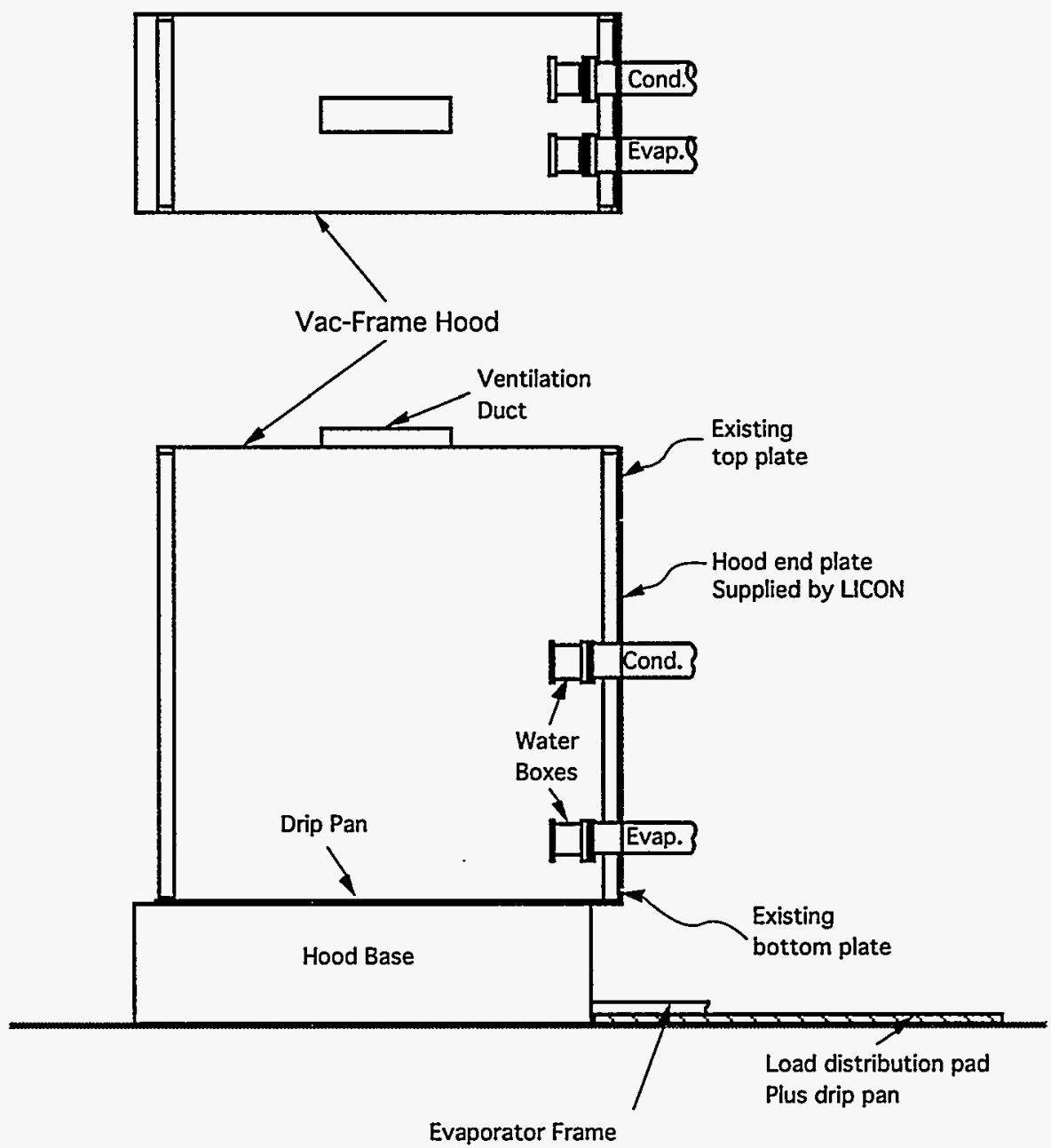

Fig. 8. Orientation of Evaporator and Vac-Frame Hood

cannot be passed through the HEPA filters at the end of that duct work. A temporary connection between the hood and the building's ventilation system has been made; it will suffice until the work with acidic feeds begins.

Ventilation to other parts of the evaporator not contained within the hood will be needed as the experimental work progresses. Specifically, changing the separator shell will require disassembling the separator section. A localized ventilation scoop is being planned to provide proper fume removal from this area.

The layout of the laboratory showing the evaporator and hood is shown in Fig. 9. The Blickman hood seen in Fig. 9 is being installed. This hood will be used for handling chemicals and preparing solutions.

\section{Corrosion Resistance of Materials Used in the Laboratory-Scale Evaporator}

Five construction materials in the laboratory-scale evaporator will come in contact with the waste solutions. The evaporator shell is chlorinated polyvinyl chloride (CPVC); the internal heat transfer tubes are titanium; the condenser is unplasticized polyvinyl chloride (Type 1, PVC); the 


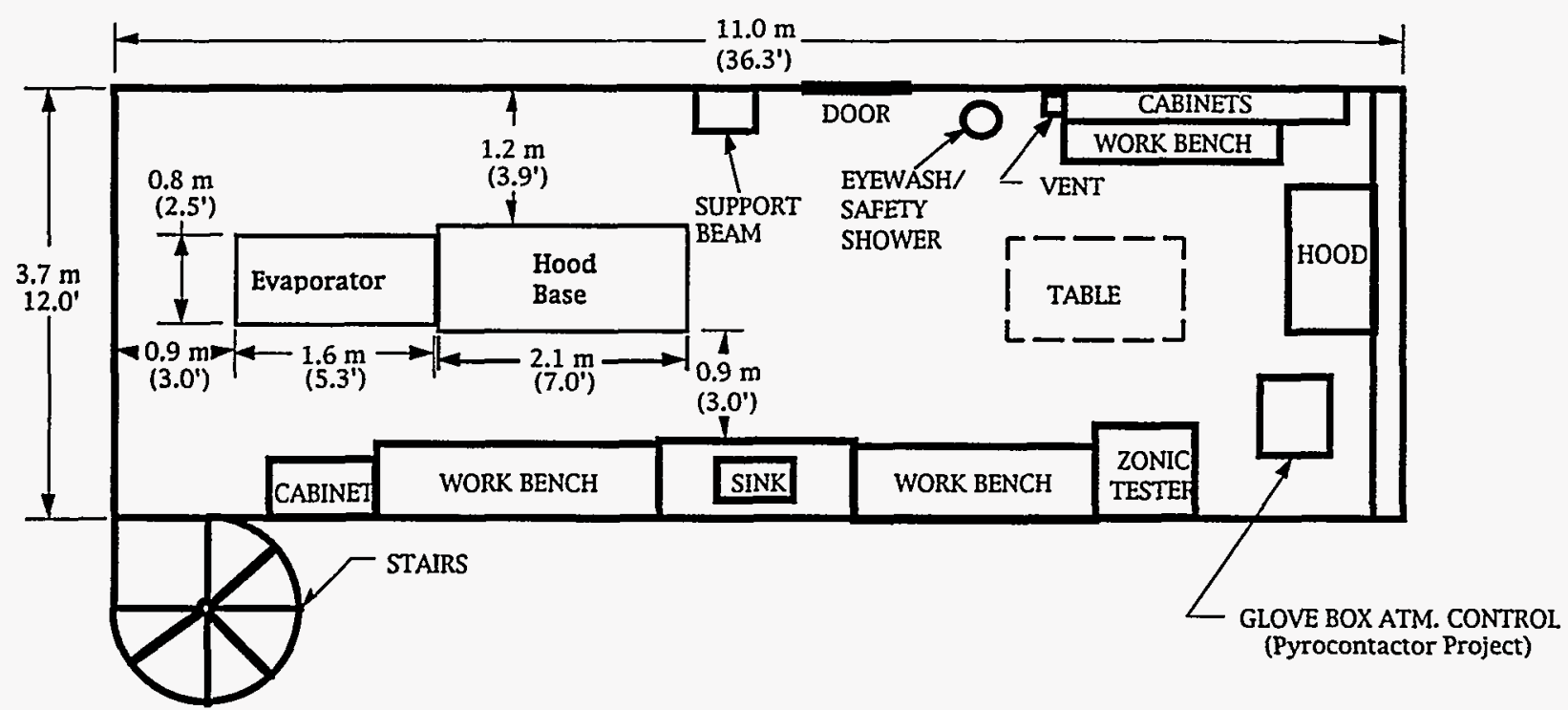

Fig. 9. Location and Footprint of Evaporator and Hood within the Laboratory

sight windows are acrylic (Plexiglas); and the support for the internal sensors inside the evaporator is polypropylene. In general, both PVC and CPVC are resistant to dilute mineral acids (e.g., sulfuric acid, hydrochloric acid, and nitric acid) and to most alkaline materials (e.g., ammonium hydroxide). However, neither is resistant to most ketones, aromatics, or chlorinated hydrocarbons. Titanium, like most metals, is subject to corrosion in acid and/or salt solutions, but it resists corrosion in most organic liquids.

Corrosion-performance data from standard corrosion references are summarized in Table 6 [HARPER, SCHWEITZER]. Plastics do not undergo the same type of electrochemical corrosion as do metals. Some plastics resist failure by solvation, swelling, chemical reaction, or softening; others are unsatisfactory. Since materials vary between manufacturers, a satisfactory performance in these tables may not be indicative of the performance of any given purchased material. However, properly manufactured, quality materials should perform as predicted by these tables. Strength testing for these materials should be performed to guarantee performance in these corrosive environments.

The data for titanium are shown in Table 7. As discussed previously, as titanium corrodes, certain dissolved species such as $\mathrm{Si}(\mathrm{IV}), \mathrm{Cr}(\mathrm{VI}), \mathrm{Fe}(\mathrm{III})$, and $\mathrm{Ti}(\mathrm{IV})$ will inhibit corrosion. Thus, purging the evaporator will accelerate the corrosion process.

As shown previously, titanium limits the fluids that can be used in the laboratory-scale evaporator, since it is the material which is most susceptible to degradation. Hydrofluoric acid must be avoided at all concentrations in the evaporator. Data indicate that oxalic acid (5\% or greater) and phosphoric acid ( $10 \%$ or greater) must also be avoided, since the evaporator will be heated above $100^{\circ} \mathrm{F}$. Nitric acid solutions can be handled safely as long as their concentrations do not approach $100 \%$ anhydrous nitric acid.

Acrylic is a rigid thermoplastic (below the glass transition temperature) used for windows, light fixtures, and signs. Its chemical name is polymethyl methacrylate, and its common name is Plexiglas. It is very dimensionally stable and softens in the temperature range $167-190^{\circ} \mathrm{F}$, 
Table 6. Corrosion Characteristics of PVC, CPVC, Acrylic, and Polypropylene in Hydrofluoric, Nitric, Oxalic, and Phosphoric Acids

\begin{tabular}{lccccc}
\hline & & \multicolumn{4}{c}{ Maximum Reported Temperature ${ }^{\circ} \mathrm{C}\left({ }^{\circ} \mathrm{F}\right)$} \\
\cline { 3 - 6 } Acid & Concentration, \% & PVC & CPVC & Acrylic & Polypropylene \\
\hline Hydrofluoric & Dilute & $66(150)$ & $27(80)$ & NE $^{\mathrm{b}}$ & $93(200)$ \\
Hydrofluoric & 30 & $66(150)$ & ND & ND & $93(200)$ \\
Hydrofluoric & 40 & $66(150)$ & $77(170)$ & ND & $93(200)$ \\
Hydrofluoric & 50 & $27(80)$ & ND & ND & $93(200)$ \\
Hydrofluoric & 70 & ND & ND & ND & $93(200)$ \\
Hydrofluoric & 100 & ND & ND & $27(80)$ & $93(200)$ \\
Nitric & 5 & $66(150)$ & $93(200)$ & $27(80)$ & $66(150)$ \\
Nitric & 10 & $66(150)$ & $93(200)$ & $27(80)$ & $66(180)$ \\
Nitric & 20 & $66(150)$ & $71(160)$ & ND & $66(150)$ \\
Nitric & 30 & $66(150)$ & $93(200)$ & ND & $66(150)$ \\
Nitric & 40 & $66(150)$ & $82(180)$ & ND & $66(150)$ \\
Nitric & 50 & $66(150)$ & $82(180)$ & ND & $66(150)$ \\
Nitric & 70 & $66(150)$ & ND & ND & ND \\
Nitric & 100 & ND & ND & ND & ND \\
Oxalic & 5 & $60(140)$ & $60(140)$ & $27(80)$ & \\
Oxalic & 10 & $60(140)$ & $82(180)$ & $27(80)$ & $66(150)$ \\
Oxalic & 50 & $60(140)$ & $93(200)$ & $27(80)$ & $66(150)$ \\
Oxalic & Satd. & $60(150)$ & $93(200)$ & $27(80)$ & $66(150)$ \\
Phosphoric & 10 & $60(150)$ & $82(180)$ & $27(80)$ & $116(240)$ \\
Phosphoric & $25-50$ & $66(150)$ & $82(180)$ & $27(80)$ & $99(210)$ \\
Phosphoric & $50-85$ & $60(140)$ & $82(180)$ & $27(80)$ & $99(210)$ \\
\hline
\end{tabular}

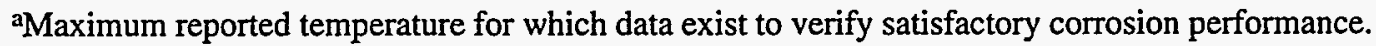

bNo data.

depending on the formulation of the material. It absorbs up to $0.3 \%$ water at room temperature, and some slight swelling occurs. It does not resist organic solvents such as acetone, benzene, and gasoline. Corrosion data for acrylic hydrofluoric acid, nitric acid, oxalic acid, and phosphoric acid are shown in Table 6 [HARPER, SCHWEITZER].

The maximum operating temperature for polypropylene is $248^{\circ} \mathrm{F}\left(120^{\circ} \mathrm{C}\right)$. Polypropylene is very resistant to mineral acids and salt solutions, but it is not resistant to organic solvents such as aromatics, chlorinated hydrocarbons, and gasoline derivatives. Corrosion data for polypropylene in hydrofluoric acid, nitric acid, oxalic acid, and phosphoric acid is summarized in Table 6 [HARPER, SCHWEITZER]. Polypropylene is used to support internal sensors inside the evaporator.

A borosilicate glass (Pyrex) may be used instead of acrylic for the evaporator site glasses. Borosilicate glasses do not resist hydrofluoric acid at all. They are very resistant to nitric acid solutions even at elevated temperatures $\left(210^{\circ} \mathrm{F}, 100 \%\right.$ acid, and much higher temperatures for more dilute acids) and to both oxalic acid and phosphoric acid to temperatures above $200^{\circ} \mathrm{F}$ [SCHWEITZER]. 
Table 7. Corrosion Rates for Titanium in Hydrofluoric, Nitric, Oxalic, and Phosphoric Acids

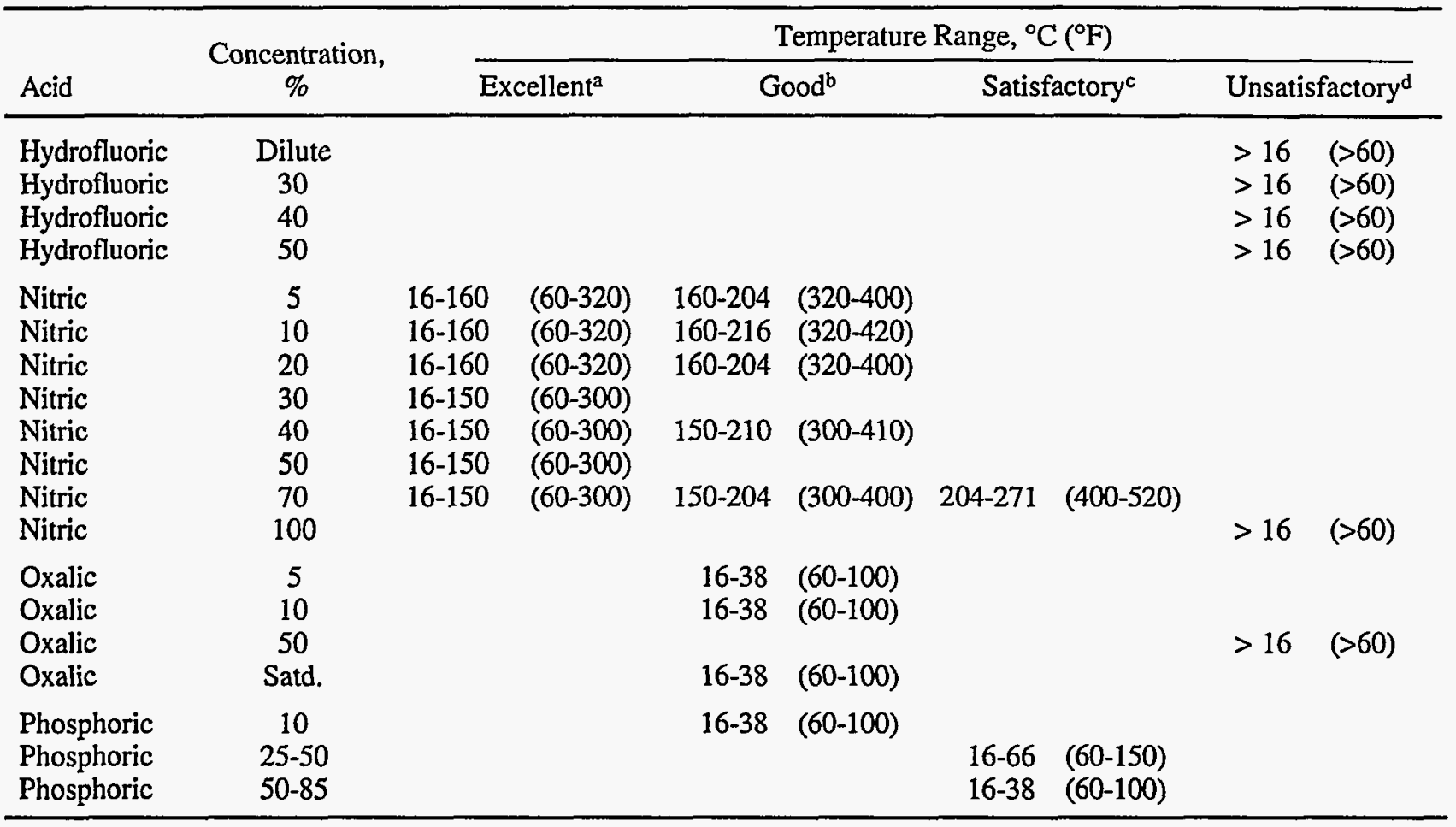

aExcellent means that the corrosion rate is $<0.002$ inches/year.

${ }^{b}$ Good means that the corrosion rate is $<0.02$ inches/year.

cSatisfactory means that the corrosion rate is $<0.05$ inches/year.

dUnsatisfactory means that the corrosion rate is $>0.05$ inches/year.

\section{E. Procedures and Documentation}

Operational and test procedures have been written for the laboratory-scale evaporator. The operating manual supplied by LICON has been modified for our use as a result of test runs of the evaporator. Future modifications will be made as testing proceeds. Procedures for testing the automatic shutdown systems have been developed and tested, and a log sheet was designed to document these tests. A data log sheet has been developed to be used in future evaporator runs.

\section{F. Test Results}

The laboratory-scale evaporator has usually been operated using water as feed. The runs with water were made to (1) verify that the unit was in good operating condition after delivery, (2) train ANL personnel in operating and maintenance procedures, and (3) verify the procedures written to supplement the operating manual.

Two experimental runs were made using salt solutions as feed to the evaporator. The runs used feeds of $6.7 \mathrm{E}-4 \mathrm{M}$ solution of samarium nitrate and a $0.5 \underline{\mathrm{M}}$ aluminum nitrate, $6.7 \mathrm{E}-3 \underline{\mathrm{M}}$ samarium nitrate mixture, respectively. Volume reductions of about $470 \%$ were attained between the feed and the concentrate. Samarium was used as a tracer; and its concentration in the feed, concentrate, and distillate streams was determined by neutron activation analysis. Data from these experimental runs is still being analyzed. 


\section{G. Preparations for Acidic Feeds}

Several tasks need to be done before the acidic feeds can be evaporated. Most importantly, work on the ventilation system must be completed: (1) completion of the design and fabrication of the filter housing for the adsorptive filters, (2) fabrication of vent lines from the concentrate and distillate tanks to the hood, and (3) design and fabrication of the localized ventilation scoop over the separator. There are a number of minor details also needing attention before acidic feeds can be used (e.g., labeling of acid-carrying tubing and replacement of acrylic sight windows).

\section{H. Neutron Activation Analysis}

During normal operation of the evaporator a decontamination factor (DF) of $10^{5}$ to $10^{7}$ must be attained. The decontamination factor is defined as follows:

$$
\mathrm{DF}=\frac{\text { Liquid-phase concentration }}{\text { Vapor-phase concentration }}
$$

A DF of $10^{7}$ means that the concentration in the vapor phase is $10^{7}$ less than the concentration in the liquid phase. Radioactive tracers seem ideally suited for measuring decontamination factors in the evaporator. Detection limits for tracers are typically very low, so DFs of $10^{7}$ would be easily measured; however, they would contaminate the equipment, complicating future work on the evaporator and increasing the costs for installing the evaporator and for conducting future tests. In addition, using radioactivity at LICON is prohibited. Therefore, an analytical method is needed to measure low concentrations of an element. One such procedure is called neutron activation analysis (NAA). This method is described in detail below.

Neutron activation analysis is simply the creation of a radioactive element as the result of neutron interaction with a stable isotope. When a neutron (n) collides with a nucleus, the following reactions may occur: elastic scattering $(n, n)$, inelastic scattering $\left(n, n^{\prime}\right)$, radioactive capture $(n, \gamma)$, charge-particle reaction $(n, a)$ or $(n, p)$, neutron producing reaction $(n, 2 n)$, and fission $(n, f)$ (where $n$ is a neutron, $\mathrm{n}^{\prime}$ is a second neutron, $\gamma$ is a gamma particle, $\mathrm{p}$ is a proton, and $\mathrm{f}$ stands for fission). The most useful reaction in NAA is radioactive capture, which can be denoted as

$$
\mathrm{n}+\mathrm{A} \mathrm{Z} \rightarrow{ }^{\mathrm{A}+1} \mathrm{Z}^{*} \rightarrow{ }^{\mathrm{A}+1} \mathrm{Z}+\gamma
$$

where ${ }^{A+1} Z^{*}$ is called the compound nucleus, which is usually in an excited state. It can de-excite by emitting of a gamma-ray called a "prompt gamma." In many cases, the ${ }^{A+1} Z$ also decays by emitting gamma rays called "delayed gammas." These delayed gammas can be detected using a highresolution, gamma-sensitive detector. A complete derivation of equations used to relate counts obtained from the detector to the concentration of an element present in a sample is given in Appendix C.

Neutron activation analysis is performed at the University of Illinois. The operating TRIGA reactor, using the "lazy-susan" facility, can provide a thermal flux of $3.3 \times 10^{12}$ neutrons $\mathrm{cm}^{-2} \mathrm{sec}^{-1}$ at $1.5 \mathrm{MW}$ and can irradiate up to 80 samples simultaneously. For higher neutron fluxes, an in-core facility for thermal $\left(1.2 \times 10^{13}\right.$ neutrons $\mathrm{cm}^{-2} \mathrm{sec}^{-1}$ at $\left.1.5 \mathrm{MW}\right)$ and epithermal $\left(1.0 \times 10^{12}\right.$ neutrons $\mathrm{cm}^{-2} \mathrm{sec}^{-1}$ at $\left.1.5 \mathrm{MW}\right)$ irradiation positions is also available. The NAA facility is located in the Materials Research Laboratory. It is equipped with three distinct 
counting systems: a 19\%-efficient germanium detector in conjunction with a Compton suppression system, a 13\%-efficient Gamma-X detector capable of detecting both $\mathrm{X}$ - and gamma rays, and a 24\%-efficient germanium detector in conjunction with a sample changer. All data-collection and analysis routines incorporate ORTEC hardware and software using three personal computers.

To use neutron activation for measuring decontamination factors in the evaporator, a stable, inexpensive element with a large cross section for radioactive capture is necessary. We reviewed the elements and identified samarium as an element suitable for our application. Samarium-152 has a radioactive capture cross section $\sigma_{y}$ of 208 barns. The radioactive capture reaction produces ${ }^{153} \mathrm{Sm}$, which has a half-life of 1.929 days and emits a $103.2-\mathrm{keV}$ gamma-ray. The two-day half-life allows sufficient time for analysis and relatively rapid decay, so that radioactive waste production is not a concern.

To be certain that we can detect the desired DFs for the evaporator, we needed to determine the detection limits of our system. According to Currie [CURRIE], a detection limit is the minimum value at which a given analytical procedure may be relied upon to lead to detection. This detection limit $\left(L_{D}\right)$ is defined as

$$
\mathrm{L}_{\mathrm{D}}=2.71+4.65 \sqrt{\mu_{\mathrm{B}}}
$$

where $\mu_{\mathrm{B}}$ is the average background counts. For NAA, this value corresponds to the minimum number of counts at which a given analytical procedure may be relied upon to lead to detection.

Detection limits may also be related to physical quantities. For example, $\mathrm{L}_{\mathrm{D}}$ may be related to the minimum detectable concentration by means of

$$
\mathrm{L}_{\mathrm{D}}=\mathrm{KC}_{\mathrm{D}}
$$

where $\mathrm{K}$ represents an overall calibration factor relating the detector response to the concentration present and $C_{D}$ represents the minimum detectable concentration. For NAA, $K$ would be equal to the net counts per concentration unit (net counts/ppm). In NAA, a reference standard with a known concentration is irradiated with the samples of unknown concentration. The $\mathrm{K}$ factor is obtained from the counting data and the known concentration of this reference standard. Once the detection limit and $\mathrm{K}$ have been determined, then the minimum detectable concentration is given by

$$
C_{D}=\frac{L_{D}}{K}
$$

Experiments were conducted to determine the minimum detectable concentration of samarium in solution. Solutions of $10,0.001$, and $0.0000001 \mathrm{ppm}$ samarium in nitric acid and water were prepared from a samarium standard. The standard was a samarium atomic absorption standard solution consisting of $995 \mathrm{mg} / \mathrm{mL}$ of samarium in $1 \mathrm{wt} \% \mathrm{HNO}_{3}$ (Aldrich Chemical Company). The 10 -ppm solution was prepared by placing $1 \mathrm{~mL}$ of the standard in a $100-\mathrm{mL}$ volumetric flask, adding $1 \mathrm{~mL}$ of Baker Ultra Pure concentrated nitric acid, then filling to $100 \mathrm{~mL}$ with distilled water. The $0.1-\mathrm{ppm}$ solution was prepared by diluting $1 \mathrm{~mL}$ of the $10-\mathrm{ppm}$ solution in another $100-\mathrm{mL}$ volumetric flask. The same procedure was followed to produce the remaining solutions. One-milliliter samples of each concentration were placed in polyethylene vials, which were then heat sealed to prevent leakage. 
The samples were irradiated in the lazy susan facility for 5 hours at $1500 \mathrm{~kW}$. The $10-, 0.001-$, and 0.0000001-ppm samples were each counted twice on the Compton suppression system. The $10-\mathrm{ppm}$ solution was counted for 30 minutes and then again for 5 minutes. The other samples were all counted for 10 hours. To check the data for errors, the concentrations of the samples were calculated using a neutron activation data analysis (NADA) program developed at the University of Illinois. The program uses the method described in Appendix $C$ and corrects for dead time using the $\mathrm{P}$ factor method [LINDSTROM]. In NAA, a known reference standard is normally compared to samples of unknown concentration. For these calculations, the first 10-ppm solution that was counted for 30 minutes was considered the reference standard. This means that for this sample, we assumed the concentration was exactly $10 \mathrm{ppm}$. The concentration of the other samples was then calculated from the experimental data. The results are given in Table 8.

Table 8. Calculated and Actual Concentrations of Samarium Standards

\begin{tabular}{ccc}
\hline $\begin{array}{c}\text { Prepared Conc., } \\
\mathrm{ppm}\end{array}$ & $\begin{array}{c}\text { Calculated Conc., } \\
\mathrm{ppm}\end{array}$ & $\begin{array}{c}\text { Error, } \\
\%\end{array}$ \\
\hline $10^{\mathrm{a}}$ & 9.95 & 0.5 \\
0.001 & 0.00107 & 7.0 \\
0.001 & 0.00106 & 6.0 \\
$1 \times 10^{-7}$ & $2.0 \times 10^{-5}$ & $20,000^{\mathrm{b}}$ \\
$1 \times 10^{-7}$ & $2.3 \times 10^{-5}$ & $23,000^{\mathrm{b}}$ \\
\hline
\end{tabular}

aFive-minute counting time.

bPossible contamination during sample preparation.

The results are in agree well or the 10- and 0.001-ppm solutions. The error for the $1 \times 10^{-7}$-ppm sample, however, is very large and is probably due to background-level contamination during sample preparation and/or handling. Using the method described above and in Appendix $\mathrm{C}$, the minimum detectable concentration was found to be $2 \times 10^{-5} \mathrm{ppm}$. The $\mathrm{K}$ factor was determined from the 10-ppm solution since it was used as the reference standard. To verify that the data can be reproduced and to check the data at $1 \times 10^{-7} \mathrm{ppm}$, the experiment will be repeated.

In summary, it is possible to use a stable, nonradioactive element to determine DFs in the evaporator. Neutron activation analysis appears to be well suited for this type of measurement. A minimum detectable concentration of $2 \times 10^{-5} \mathrm{ppm}$ was found for samarium in nitric acid following irradiation of 5 hours at $1500 \mathrm{~kW}$ and a sample counting time of 10 hours.

\section{WASTE MANAGEMENT EVAPORATOR UPGRADE}

\section{A. Introduction}

This year, WMO was funded to replace two low-level waste evaporators that have been in operation at ANL for over 30 years. Two LICON evaporators will be designed, purchased, and installed in FY-93. This project has been incorporated into our program and will assist us by collecting operating data on the processing of actual waste solutions. Collaboration between WMO's ongoing waste minimization program and CMT's R\&D program enhances both programs. Benefits of this joint program include (1) valuable operating experience of a full-scale LICON-designed evaporator in the third year of the program, (2) a significant capital equipment savings for the R\&D 
program, (3) demonstration of evaporator on actual waste solutions early in the program, and (4) technical support for WMO's daily operation.

\section{B. Description of Existing System}

The two 30-year-old WMO evaporators are installed in building 306, where they are used to process low-level liquid waste. These 3-GPM units are natural circulation, vertical-tube evaporators. The evaporator sections consist of 63 titanium tubes, $6-\mathrm{ft}(1.83-\mathrm{m})$ long, 0.75 -in. $(1.90-\mathrm{cm})$ diameter. Steam is supplied to the outside of the tubes, while process solution flows through the inside of the tubes. One-hundred-pound steam is used in the evaporator section; each unit consumes approximately $1600 \mathrm{lb} / \mathrm{hr}$ steam while being operated at $3 \mathrm{GPM}$. The condenser section consists of double bypass U-tubes. Site water is used as the cooling fluid.

Two 15,000-L (4000-gal) acid storage tanks hold feed for the evaporator. The feed solutions are neutralized to a nominal $\mathrm{pH}$ of 9 with sodium hydroxide. The $\mathrm{pH}$ is checked with $\mathrm{pH}$ paper. Once the waste is neutralized, it is transferred to a series of 1400-gal (5300-L) feed tanks, then pumped to the evaporator. The evaporator has a holdup of $200 \mathrm{gal}$, and waste from the 5300-L (1400-gal) feed tanks is continuously fed into it until the tanks are empty. The evaporator is operated at a nominal pressure of 5 psig until the boil-up drops to zero. After evaporation, the concentrate is transferred to a vacuum concentrator, which reduces the liquid volume further to 8-60 L (2-15 gal). Often, the concentrate from the vacuum concentrator is high in solids and has a paste-like appearance. Currently, it is absorbed on amorphous silicate (WYK-Upright Inc., Rock Hill, MO). The distillate from the main evaporator is sent to a series of four $15,000-\mathrm{L}$ (4000-gal) suspect waste storage tanks, checked for radioactivity, and dumped to the laboratory waste treatment facility. If necessary, it is recycled back to the main evaporator for reprocessing, although that has occurred only three times in 20 years. The distillate from the vacuum concentrator is always recycled back to the acid waste tanks.

\section{Process Feed Composition}

To design an appropriate evaporator for processing ANL's low-level waste solutions, a typical feed composition is needed. This composition will be used to prepare surrogate solutions for laboratory testing. Unfortunately, a complete analysis of the waste solutions being processed is not normally completed. However, 4055 -gal drums of solids were recently removed from the neutralization tanks. They resulted from years of waste accumulation. Samples of these solids were collected for analysis. In order to determine the liquid feed composition, liquid taken with one of the solid samples from the acid waste tanks was analyzed. Sample AWT-AB was used, since it had the highest weight percent of liquid of all the waste sludge samples. The composition of this liquid is shown in Table 9, which also shows the charge balance.

The charge balance is fairly good, considering the sample came from a complex mixture of waste liquid containing a high concentration of suspended solids. A small correction in $\mathrm{pH}$ would significantly change the $\mathrm{HCO}_{3}-/ \mathrm{CO}_{3}{ }^{2-}$ balance. The solids were filtered, and only the liquid was used in the analysis. Results of the toxicity characteristic leaching procedure (TCLP) were also completed on this liquid sample, and trace amounts of RCRA hazardous materials were found.

\section{New Evaporator Design}

Based upon future waste receipts as identified by WMO and a typical feed composition, two replacement evaporators will be designed and fabricated by LICON. The 
Table 9. Evaporator Feed Solution Composition

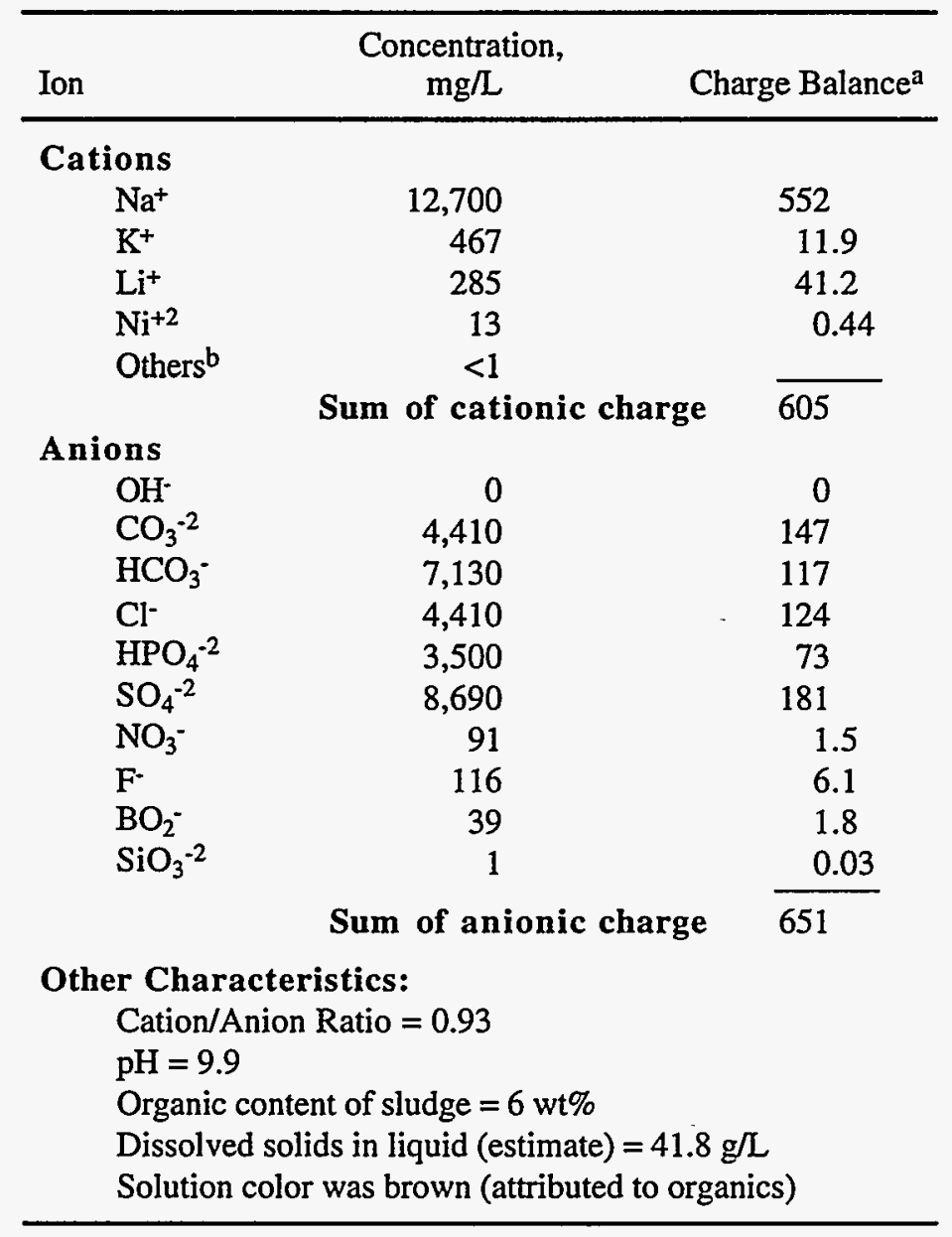

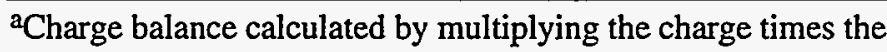
concentration (in $\mathrm{mg} / \mathrm{L}$ ), then dividing by molecular weight. bOther cations detected at concentrations less than $1 \mathrm{mg} / \mathrm{L}$ include $\mathrm{Co}, \mathrm{Cd}, \mathrm{Zn}, \mathrm{Pb}, \mathrm{Fe}, \mathrm{Mn}, \mathrm{Cr}, \mathrm{Cu}, \mathrm{Ca}, \mathrm{Al}, \mathrm{Mg}, \mathrm{V}, \mathrm{Be}$, and $\mathrm{Ba}$.

laboratory-scale evaporator discussed in the previous section will be used to study how the surrogate solution behaves and to evaluate the final evaporator design.

\section{PHYSICAL PROPERTIES FOR EVAPORATOR LIQUIDS}

Designing an effective process for concentrating process streams requires both solubility and vapor/liquid equilibrium data. Solubility data are needed to determine the amount of solution concentration that can be achieved without precipitating any components from the solution. The vapor/liquid equilibrium data are needed to predict the vapor-phase concentrations for any of the various solution compositions that will be processed. Together, these measurements will be used to set conditions of pressure and temperature, to predict effluent rates and compositions for the condensate and the bottoms, and to determine the degree to which a stream can be concentrated. These data may also have an impact on the design of the evaporator.

A literature survey was completed to determine what information is available. References on aqueous nitric, sulfuric, phosphoric, and oxalic acids were obtained, as well as the effects of various 
metal salts in solution. The next step was to use aqueous-phase activities to develop a model that would predict vapor-phase compositions. This model would use aqueous-phase activities calculated by the Generic TRUEX Model (GTM) to make these predictions.

A summary of the literature survey is given in the following two sections: Section VI.A is an overview of the solubility data; Section VI.B describes the vapor/liquid equilibrium data. The complete literature survey is given in Appendices A (solubility data) and B (equilibrium data). Vapor/liquid equilibrium data that are not available in the literature but are necessary for the success of this program will be obtained experimentally. A laboratory still was purchased for that purpose. Details on the laboratory still and the literature search on laboratory equipment are given in Section VI.C. The work completed in predicting the partial pressures of nitric acid and water in nitric acid-salt solutions is reported in Section VI.D.

\section{A. Solubility Data}

As described above, the composition at which solids precipitate from mixed acid/metal-salt solutions as functions of temperature, pressure, and composition is important in designing a process to concentrate liquid streams. The evaporator being developed in this program can handle small amounts of solids suspended in solution. It is desirable, however, to operate the evaporator at a solution composition that would not precipitate solids. To determine these compositions, a literature survey was performed. The nitrate salts of major importance in this project are aluminum, calcium, iron, lanthanum, nickel, sodium, uranium, and the lanthanides. Solubility data were obtained for each of these salts as a function of acid concentration at constant temperature. The data were presented in units of weight percent. Solution densities, calculated for the data at $25^{\circ} \mathrm{C}$, were used to convert the solubility data from weight percent to molar concentrations of salt and nitric acid. Plots of the data showed that aluminum nitrate had the lowest solubility of the nitrate salts studied. Solubility data at temperatures other than $25^{\circ} \mathrm{C}$ were also collected for some of the salts.

A complete report on the solubility of nitrate salts in nitric acid-water-nitrate salt systems is given in Appendix A.

\section{B. Vapor-Liquid Equilibrium Data}

The TRUEX waste streams consist mainly of aqueous nitric acid solutions containing metal nitrate salts. To design the evaporator for concentrating specific TRUEX waste streams, it is important to know the concentration of water and nitric acid in the liquid and vapor phases as functions of temperature, pressure, and composition of aqueous solution. However, some solutions may also contain other acids, such as sulfuric, phosphoric, hydrofluoric, and oxalic. It is also important to understand the effects of these acids on the system.

A literature survey was carried out to evaluate the effect the presence of metal nitrate salts has on the vapor-liquid equilibria of aqueous solutions of $\mathrm{HNO}_{3}$. The most useful source of information was a set of five books by Wichterle et al. [WICHTERLE-1973, WICHTERLE-1976, WICHTERLE-1979, WICHTERLE-1982, WICHTERLE-1985]. These books have almost 8500 vapor-liquid equilibrium systems studied from 1900 through 1984. Many applicable references were obtained from this source for both nitric acid-water and nitric acid-water-nitrate salt systems.

In TRUEX waste streams, the nitrate salts present in the largest concentrations are $\mathrm{Al}$, $\mathrm{Ca}, \mathrm{Fe}, \mathrm{La}, \mathrm{Na}, \mathrm{Ni}$, and $\mathrm{UO}_{2}$ nitrates. Therefore, these seven nitric acid-water-nitrate salts systems were 
studied. The review discussed the effect that system pressure and salt concentration in the liquid phase had on (1) the vapor phase composition and (2) the boiling point of the system.

Several trends are evident from this survey. Based upon data at various pressures, reducing the pressure decreases the boiling point of the system but has little impact on the vaporphase compositions. The presence of salts, with the exception of potassium nitrate, tends to salt out the nitric acid into the vapor phase, thus enriching the vapor phase in nitric acid. The solution boiling point also tends to increase as the salt concentration increases.

The review also investigated multiple-acid systems, including nitric acid-water-sulfuric acid and nitric acid-water-phosphoric acid. Information on these systems was very limited. Based upon these data, the presence of the second acid tended to salt out the nitric acid into the vapor phase. No data were found on the nitric acid-water-oxalic acid system, nor was any data found on multiple acid-water-salt systems. These systems, if important, may be investigated using the laboratory still described in Section VI.C.

A complete report on the vapor/liquid equilibrium data is given in Appendix B.

\section{Laboratory Vapor-Liquid Equilibrium Still}

One other topic that the literature survey focused on was determining the experimental equipment necessary to collect data for nitric acid-water-nitrate salt systems. Ten papers were found which use the circulation method to determine the vapor/liquid equilibria for the nitric acid-water-nitrate salt system. The most common circulation apparatus used was the Bushmakin still [BUSHMAKIN] and modified versions of that apparatus, such as the one described by Gorodetskii [GORODETSKII]. Hála [HALA] compares 27 circulation vapor/liquid equilibrium stills. Among the stills compared are the stills by Bushmakin and Altsheler. The Bushmakin still is considered by Hála [HALA] to be a simple still that reaches equilibrium in 2-3 hours but does not measure the temperature accurately. The Altsheler still is considered a very precise still that reaches equilibrium in about 40 minutes but has no means of measuring temperature. The Altsheler still, fully described in [ALTSHELER] and shown in Fig. 10, is currently manufactured by LUREX Scientific (South Vineland, NJ). The Altsheler still can be easily modified to measure the temperature of the vapor and liquid. Owensby [OWENSBY] inserted two thermocouples, one for the vapor and one for the liquid phase, through the top of the Altsheler still. With these considerations in mind, the Altsheler still should be adequate for our use in collecting experimental data on systems that have not been reported in the literature. Therefore, an Altsheler still was purchased from LUREX Scientific. This unit has been installed at the University of Illinois Nuclear Engineering Department and will be used next year.

While the equilibrium still purchased from LUREX Scientific will be used for nitric acid systems, it cannot be used with hydrofluoric acid solutions, because most of the unit is made of glass. If hydrofluoric acid is to be studied, then another apparatus must be purchased. 


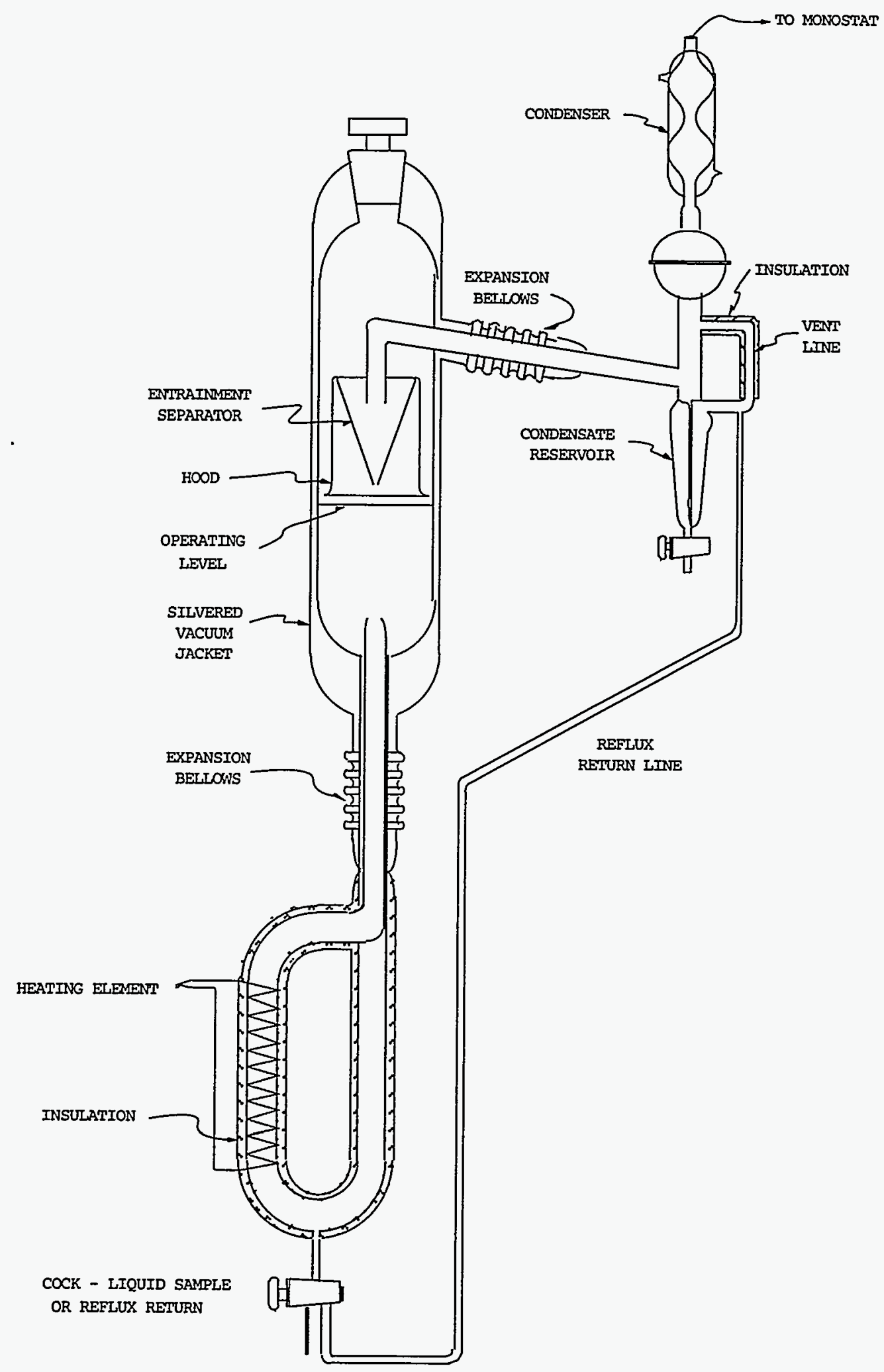

Fig. 10. Section View of Equilibrium Still [ALTSHELER]. Reprinted with permission from Industrial \& Engineering Chemistry, Vol. 43, No. 11, pp. 2559-2564 (1951). Copyright (1951) American Chemical Society. 


\section{Modeling of Vapor-Liquid Equilibrium Data}

Various factors control the operation of an evaporator, including the composition of both the vapor-liquid phases, the partial pressures of the individual components, and the temperature. These factors become complicated when the feed stream varies in composition, and a thermodynamic model becomes necessary to facilitate the generic application of an evaporation process. The ability to calculate the partial pressures of the nitric acid and water permits the evaporator distillation process to be controlled to (1) recycle nitric acid and (2) limit undesirable physical events such as precipitation. The partial pressure of any component in solution can be related thermodynamically to the composition of that component at a given temperature.

As part of the TRUEX Technology-Base Development Program, ${ }^{*}$ the Generic TRUEX Model (GTM) was developed, which calculates the aqueous-phase activities of water and nitrate and hydrogen ions in multicomponent aqueous solutions both at low and at high ionic strengths. These calculations are based on a Bromley model [ZEMAITIS], which is accurate at high ionic strengths but does not include temperature dependence. (The GTM was modified to predict the vapor-phase equilibrium by including temperature dependence on the activities.) Here we show how we obtained a temperature-dependent relationship and compare calculated and experimental measurements. We also discuss our current status on predicting vapor-liquid equilibrium.

\section{Approach}

Since the TRUEX process raffinate contains very little alpha activity $(<10 \mathrm{nCj} / \mathrm{mL})$, it can be immobilized into grout as low-level waste. However, because grout is an alkaline medium, high concentrations of nitric acid must be neutralized first. Recycling the nitric acid would significantly reduce waste volume. A convenient process to recycle the acid is evaporation.

In dilute aqueous nitric acid solutions, the partial pressure of nitric acid is relatively low. As a result, relatively little nitric acid collected in the distillate from the evaporation process, compared with water. However, when an aqueous solution of nitric acid and salts is evaporated, the partial pressure of nitric acid is greatly elevated (the "salting out" effect) and that of water is decreased. Waste and product streams, such as those generated by the TRUEX process, have an abundance of nitrate salts of sodium, aluminum, iron, and other metals at concentrations ranging from 0.1 to $1 \underline{\mathrm{M}}$. An evaporation process could be used to concentrate the nitric acid in the distillate for recycle; sufficient water would be retained in the waste solutions such that precipitation could be avoided.

Because of the variety of waste in the Hanford tanks, a broad range of feed compositions are expected to be treated; therefore, a dynamic and robust process is necessary. The evaporator is being constructed to handle a wide variety of waste streams. A thermodynamic model for the evaporator is necessary to predict the vapor-liquid equilibria for the waste solutions, and therefore to maximize nitric acid recovery.

\footnotetext{
* Funded by the Underground Storage Tank Integrated Demonstration, Office of Technology Development, DOE.
} 


\section{Theory}

For an ideal vapor above an ideal solution, Raoult's law states that the partial pressure of a species $i\left(P_{i}\right)$ is equal to the product of the mole fraction of $i\left(X_{i}\right)$ and the vapor pressure of $i\left(P_{i}^{*}\right)$ at a temperature $T$.

$$
\mathrm{P}_{\mathrm{i}}=\mathrm{X}_{\mathrm{i}} \mathrm{P}_{\mathrm{i}}^{*}
$$

Most solutions, however, do not act ideally; then, the activity of the species, $a_{i}$, is used in place of mole fraction. For the purposes of this discussion it is advantageous to express the molal units; thus, for non-ideal solutions, Raoult's law becomes

$$
P_{i}=a_{i} P_{i}^{*}
$$

where $a_{i}=\gamma_{i} m_{i}$.

When dealing with electrolytes, the degree of dissociation of the species (e.g., $\mathrm{HNO}_{3} \leftrightarrow \mathrm{H}^{+}+\mathrm{NO}_{3}{ }^{-}$) must be considered. Two activity coefficients are defined for this purpose: (1) the mean ionic activity coefficient $\left(\gamma_{ \pm}\right)$and (2) the stochiometric activity coefficient $\left(\gamma_{s}\right)$. The mean activity coefficient is used in the activity expression if the dissociation constant $\alpha$ is also used. Thus, for a 1:1 electrolyte (e.g., $\mathrm{HNO}_{3}$ )

$$
a_{\mathrm{HNO}_{3}}=\mathrm{a}_{\mathrm{H}^{+}} \mathrm{a}_{\mathrm{NO}_{3}}{ }^{-}=\left(\gamma_{\mathrm{H}^{+}} \alpha \mathrm{m}_{0}\right)\left(\gamma_{\mathrm{NO}_{3}}{ }^{-\alpha m_{0}}\right)=\left(\gamma_{ \pm} \mathrm{m}_{0} \alpha\right)^{2}
$$

where $\mathrm{m}_{0}$ is the molality of $\mathrm{HNO}_{3}$. For general applications where $\alpha$ is not known, the stochiometric activity coefficient is incorporated:

$$
a_{\mathrm{HNO}_{3}}=\left(\gamma_{\mathrm{s}} \mathrm{m}_{0}\right)^{2}
$$

Since identical activities must be obtained from the two methods, $\gamma_{ \pm}$must be greater than $\gamma_{s}$. The reason is $\gamma_{s}$ allows for ion-pair formation or the incomplete ionization of the original species. It is evident that $\gamma_{s}$ equals $\gamma_{ \pm}$in the absence of ion-pair formation. The deviations of $\gamma_{ \pm}$from 1 are identical to those explained for activity coefficients in general and are as (1) and (2) below. On the other hand, $\gamma_{s}$ deviates from 1 for one or more of the following conditions:

(1) deviation of solution from ideally dilute behavior

(2) deviation of solvent mole fraction from 1

(3) ion-pair formation, which makes $a<1$

In application to this study, both coefficients will adopt as their standard state $\lim _{\mathrm{m} \rightarrow 0} \gamma=1$, which occurs at infinite dilution. Appendix $\mathrm{D}$ describes conditions of the standard state. This convention is practical because, in general, the feed concentration into the evaporator will 
consist of many salts, while the pure component standard state (convention 1) is convenient when dealing with one or more species [LEVINE].

By the use of electrodynamic principles, Debye and Hückel derived a theoretical method to determine the mean ionic activity coefficient for a dilute aqueous solution at $25^{\circ} \mathrm{C}$. Their efforts yielded

$$
\ln \gamma_{ \pm}=-\left|z_{+} z_{-}\right| \frac{A I_{m}^{1 / 2}}{1+B a_{o} I_{m}^{1 / 2}}
$$

where $\left|z_{+} z_{-}\right|$is the absolute value of the charge of each ion, A is the Debye-Hückel constant, B is a constant, and $\mathrm{a}_{\mathrm{o}}$ is the distance of closest approach of the ions. The ionic strength of solution in molal units is I and is defined as follows:

$$
\mathrm{I}_{\mathrm{m}}=\frac{1}{2} \sum_{\mathrm{i}} \mathrm{z}_{\mathrm{i}}^{2} \mathrm{~m}_{\mathrm{i}}
$$

Refinements to the Debye-Hückel limiting law were made by Guggenheim, Pitzer, Meissner, Chen, and Bromley [ZEMAITIS].

$$
\log \gamma_{12}=\frac{-A z_{1} z_{2} \sqrt{I}}{1+\sqrt{I}}+\frac{v_{1} F_{1}+v_{2} F_{2}}{v_{1}+v_{2}}
$$

where $\mathrm{A}=$ Debye-Hückel constant, $0.5108 \mathrm{~kg}^{1 / 2} \mathrm{~mol}^{-1 / 2}$ at $25^{\circ}$

$v_{1}, v_{2}=$ stochiometric coefficients

$\gamma_{12}, \gamma_{\mathrm{ij}}=$ mean activity coefficient, molal scale

The $\mathrm{F}$ terms are defined as follows:

$$
F_{1}=\left(Y_{12} \log \gamma_{12}^{0}+Y_{14} \log \gamma_{14}^{0}+\ldots+Y_{1 j} \log \gamma_{i j}^{0}\right)+\frac{A \sqrt{I}}{1+\sqrt{I}}\left(z_{1} z_{2} Y_{12}+z_{1} z_{4} Y_{14}+\ldots+z_{1} z_{j} Y_{i j}\right)
$$

and

$$
F_{2}=\left(X_{12} \log \gamma_{12}^{0}+X_{32} \log \gamma_{32}^{0}+\ldots+Y_{i 2} \log \gamma_{i 2}^{0}\right)+\frac{A \sqrt{I}}{1+\sqrt{I}}\left(z_{1} z_{2} X_{12}+z_{3} z_{2} Y_{32}+\ldots+z_{1} z_{j} Y_{i 2}\right)
$$

where

$$
Y_{1 j}=\left(\frac{z_{1}+z_{j}}{2}\right)^{2}\left(\frac{m_{j}}{I}\right)
$$




$$
Y_{i 2}=\left(\frac{z_{i}+z_{2}}{2}\right)^{2}\left(\frac{m_{i}}{I}\right)
$$

The subscripts in Eqs. 18 through 22 are defined by the odd subscripts $(1,3,5, \ldots$, i) representing cationic species, while even subscripts $(2,4, \ldots, \mathrm{j})$ represent the anionic species. The $\gamma_{\mathrm{ij}}$ terms in Eqs. 19 and 20 refer to the stochiometric activity coefficients of the solution of the pure electrolyte ij at the ionic strength of the mixed solution at $25^{\circ} \mathrm{C}$. The $\gamma_{\mathrm{ij}}^{\circ}$ values were obtained from literature and fitted with the following equation:

$$
\log \gamma_{i j}^{0}=\frac{-A z_{i}+z_{j} \sqrt{I}}{1+B \sqrt{I}}+\beta I+C I^{2}+D I^{3}+E I^{4}
$$

where $\mathrm{B}, \beta, \mathrm{C}, \mathrm{D}$, and $\mathrm{E}$ are constants, and $\mathrm{I}$ is calculated assuming complete dissociation.

Equation 23 will be referred to as the GTM or the modified Bromley equation in the text and as the GTM in figures and tables. For a system of $\mathrm{HNO}_{3}$, salts, and water, the concentrations of $\mathrm{HNO}_{3}$ and the salts are entered into the GTM, where $\gamma_{\mathrm{ij}}^{0}$ is calculated and inserted into Eq. 18 to determine $\gamma_{\mathrm{HNO}_{3}}$. At the same time, $\gamma_{\mathrm{H}_{2} \mathrm{O}}$ is calculated. The partial pressures of $\mathrm{H}_{2} \mathrm{O}$ and $\mathrm{HNO}_{3}$ can then be calculated from Raoult's Law. Finally, the total pressure above the solution can be calculated by adding the partial pressures.

\section{Activity Temperature Dependence Results}

The stochiometric activity coefficients for $\mathrm{HNO}_{3}$ determined at $25^{\circ} \mathrm{C}$ by Davis [DAVIS] were fit to the GTM equation. The results show the following:

$$
\begin{aligned}
& B=1.1376 \\
& \beta=0.1024 \\
& C=-4.768 \times 10^{-3} \\
& D=1.0364 \times 10^{-4} \\
& E=-8.35 \times 10^{-7}
\end{aligned}
$$

For a maximum ionic strength of 48.0 molal, the GTM calculation and Davis's experimental data agree well. Beyond that, the GTM equation fits poorly. (In the GTM itself, a second equation is used to fit higher ionic-strength values.)

The coefficients that were determined for $\mathrm{HNO}_{3}$ in the GTM are only valid at $25^{\circ} \mathrm{C}$. Before a temperature dependence can be incorporated into the GTM, the terms in Eq. 23 that are temperaturesensitive must be determined. Concentration in molality, ionic charge, and, therefore, ionic strength do not vary with temperature. Pitzer has thoroughly investigated the effect of temperature on the Debye-Hückel constant [PITZER]. The osmotic activity values that he reported were converted to $\mathrm{HNO}_{3}$ activity values and a plot of $\mathrm{A}$ (the Debye-Hückel constant) versus T was created. Figure 11 shows the fit, which displays a correlation coefficient of 0.999998 , in which the constant A can be replaced with the function

$$
\mathrm{A}=0.635-0.00171 \mathrm{~T}+4.34 \times 10^{-6} \mathrm{~T}^{2}
$$


for a temperature range between 273.15 and $373.15 \mathrm{~K}$.

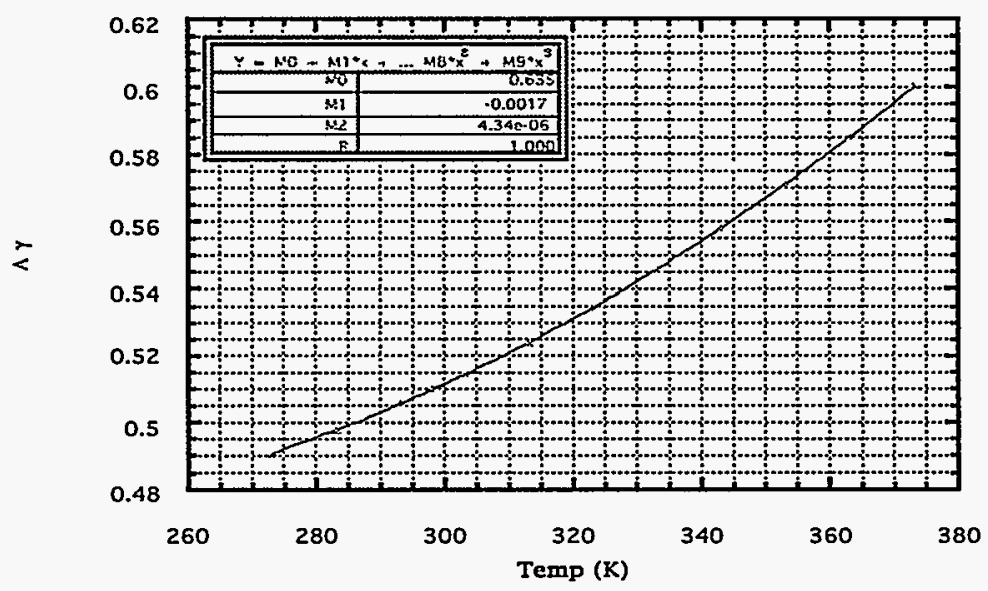

Fig. 11. Calculated Best-Fit Line for Determining the Debye-Hückel Constant A vs. Temperature

The temperature dependence of $\gamma^{\circ}$ ij is slightly more complicated. The expansion term of $\gamma^{\circ}$ (Eq. 23) shows that $\log \gamma_{\mathrm{ij}}$ is a function of $I$ and five constants $(B, \beta, C, D$, and $E)$. It has already been determined that $I$ is only a function of composition; therefore, the constants must be the temperature-sensitive terms. Since nitric acid systems are the primary concern, the data of Davis and Lemire were used for analysis. Davis reported the $\mathrm{HNO}_{3}$-water stochiometric activity coefficients at $25^{\circ} \mathrm{C}$ [DAVIS]. Lemire reported an equation for $\log \gamma_{s}$ that fits data for $\mathrm{HNO}_{3}$-water systems at $50^{\circ} \mathrm{C}$ [LEMIRE-1985]. In order to determine which coefficients are temperature-sensitive, the GTM equation was plotted against the data of Davis and Lemire. The plots show $\log \gamma$ versus $\sqrt{\mathrm{m}}$, which for 1:1 electrolytes is equivalent to $\sqrt{\mathrm{I}}$. Equation 24 replaced the original Debye-Hückel . constant in the GTM equation, and the coefficients were expanded individually into a power series. The general format for the power series was

$$
\theta=\theta_{0}+\theta_{1}(T-298.15)+\theta_{2}(T-298.15)^{2}+\ldots+\theta_{n}(T-298.15)^{n}
$$

where $\theta=$ temperature-dependent coefficient

$\theta_{0}=$ original value of constant at $25^{\circ} \mathrm{C}$

$\theta_{\mathrm{n}}=$ constants to be determined

In all cases, these equations were fit with first-order expansions. Figure 12 shows the plots of the GTM equation, with only the temperature dependence of A included for the Davis and Lemire data. It is clear that A changes only slightly with temperature.

The $B$ term was not investigated for temperature dependence. From the derivation of Debye-Hückel, the B term is related to the distance of closest approach of the ions. It is assumed to be constant at different temperatures. The $\beta$ term was expanded initially into a first-order power series. The results show a high degree of temperature dependence for B (Fig. 13), for which $\beta_{1}=-0.000451$. The GTM equation agrees better with the $50^{\circ} \mathrm{C}$ data. Also, it is important to point 


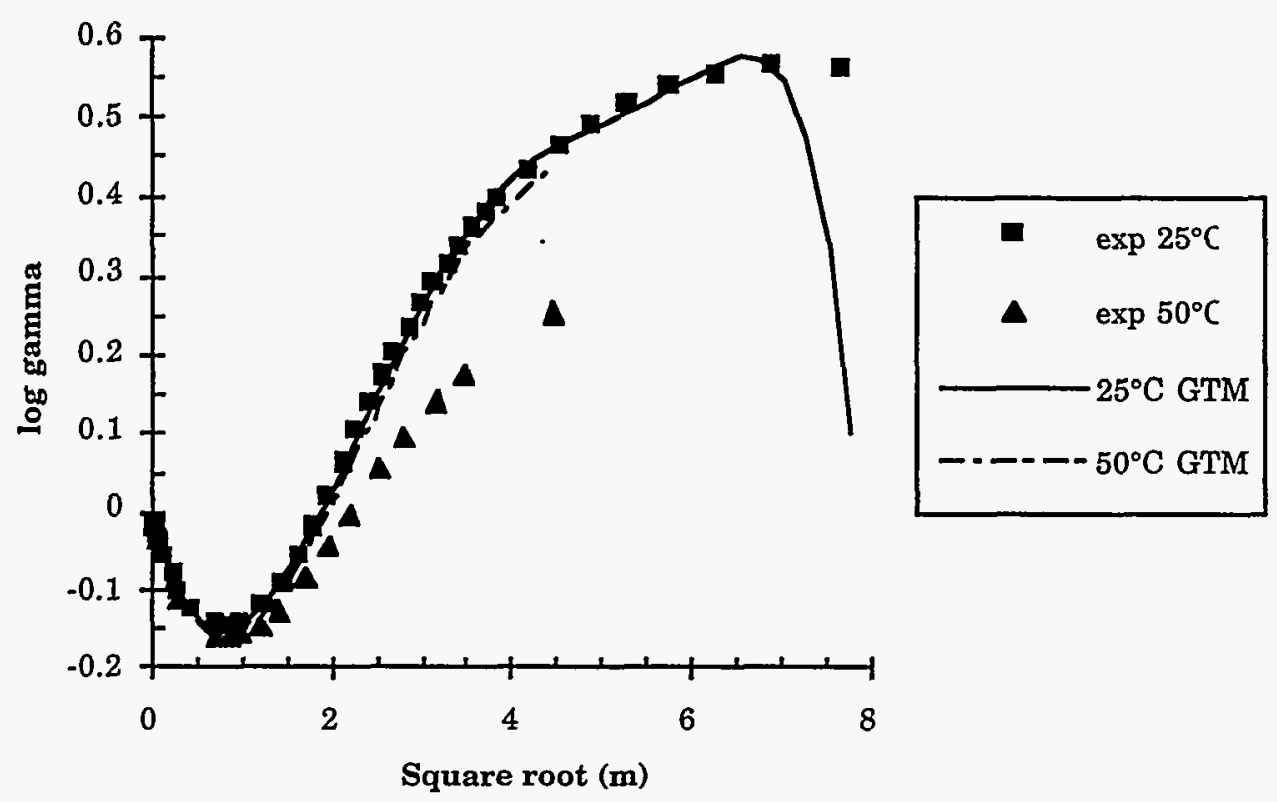

Fig. 12. Calculated $\log \gamma$ vs. the Experimental Data of Davis and Lemire. Temperatures of 25 and $50^{\circ} \mathrm{C}$ are included in the GTM calculations.

out the disagreement of the $25^{\circ} \mathrm{C}$ curves. As stated previously, the GTM equation is accurate for $\mathrm{HNO}_{3}$ concentrations $\leq 48$ molal; the plot specifically shows this limitation. The addition of a second-order power series expansion changes the fit insignificantly (Fig. 13).

Next, the $\mathrm{C}$ term was expanded into a first-order power series. A least-squares fit showed that with $C_{1}=-2.524 \times 10^{-5}$, the $50^{\circ} \mathrm{C}$ curve agrees slightly better with the data (Fig. 13). Much like the $\beta$ term, the expansion of the $C$ term into a second-order power series yielded insignificant improvement.

Expansion of both the $\mathrm{D}$ and $\mathrm{E}$ constants showed the lack of temperature dependence within these terms (Fig. 14). Recognizing the existence of temperature sensitivity in the $\beta$ and $C$ terms, the combination of the two terms were expanded into a first-order power series, and a least-squares fit was performed to determine the constants. Figure 15 shows how well they agree with the literature data. The coefficients were determined as follows:

$$
\begin{aligned}
\beta_{1} & =-0.0005992 \\
C_{1} & =1.0116 \times 10^{-5}
\end{aligned}
$$

The fit provides confidence in the application of this method.

In order to verify the format of the modified Bromley equation with its temperature-dependent terms, literature data were obtained for $\mathrm{NaCl}-\mathrm{H}_{2} \mathrm{O}$ and $\mathrm{HCl}-\mathrm{H}_{2} \mathrm{O}$ systems at various temperatures. The data, compiled by Harned and Owens [HARNED], consisted of the mean activity coefficients for solutions at various temperatures and ranged up to 4 molal. However, since $\mathrm{NaCl}$ and $\mathrm{HCl}$ are strong electrolytes, they experience complete dissociation, where $\gamma_{s}=\gamma_{ \pm}$. 


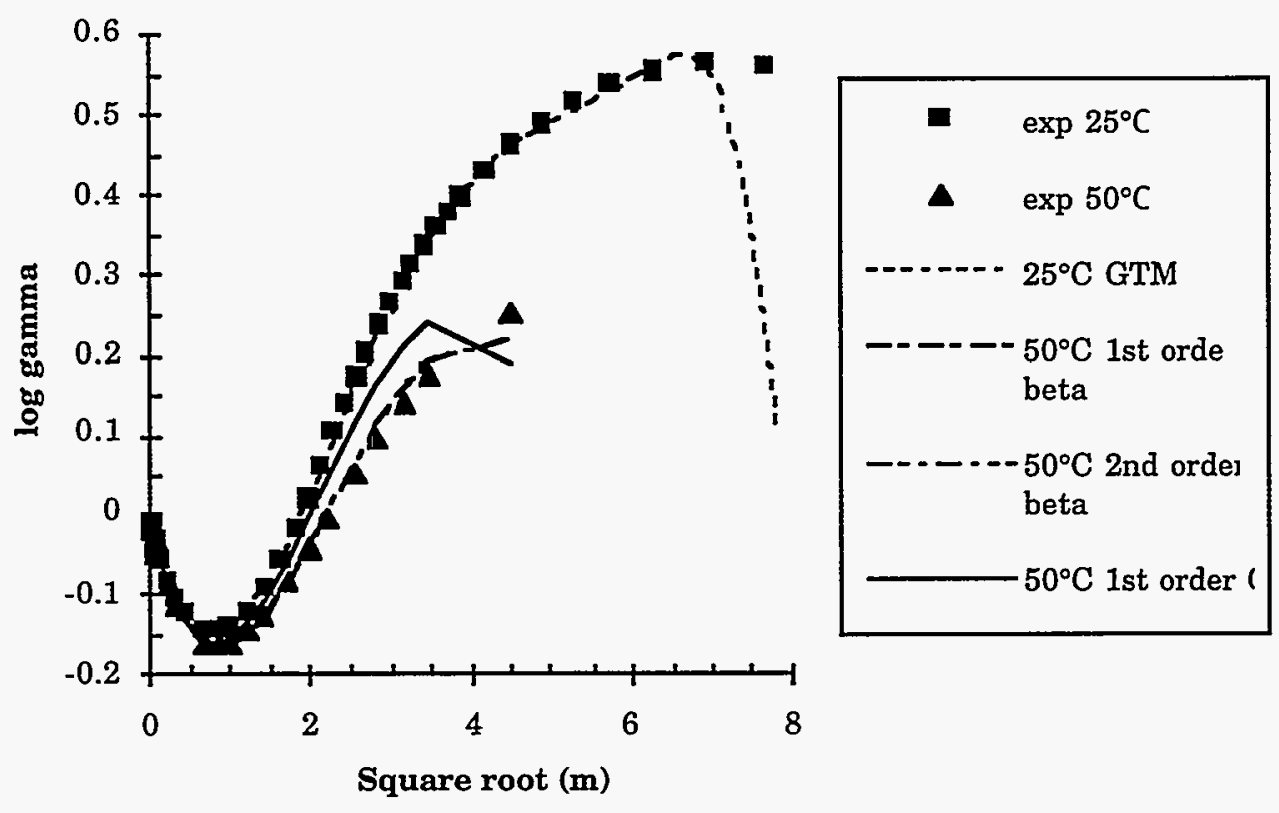

Fig. 13. Calculated $\log \gamma$ with Temperature-Dependence of $A, \beta$, and $C$ vs. the Experimental Data. Results show the temperature dependence of $A$ and $\beta\left(\beta_{1}\right)$ included in the GTM calculations, temperature dependence of $A$ and $\beta\left(\beta_{1}\right.$ and $\beta_{2}$ ) included in the GTM calculations, and finally the temperature dependence of $A$ and $C\left(C_{1}\right)$ included in the GTM calculations. Experimental data taken from Davis and Lemire. Temperatures are 25 and $50^{\circ} \mathrm{C}$.

The $\mathrm{NaCl}$ data were fit to the GTM equation following the same procedure as for $\mathrm{HNO}_{3}$. Harned and Owens reported data for $15,25,35$, and $50^{\circ} \mathrm{C}$. The coefficients of $\mathrm{B}, \beta_{0}, \mathrm{C}_{0}$, $\mathrm{D}$, and $\mathrm{E}$ were determined at $25^{\circ} \mathrm{C}$ :

$$
\begin{aligned}
& B=1.5407 \\
& b_{0}=0.1024 \\
& C_{0}=0.0218 \\
& D=-0.0050 \\
& E=0.000482
\end{aligned}
$$

Next, a first-order power-series expansion was performed on the $\beta$ and $\mathrm{C}$ terms and the coefficients were determined such that the sum of the least squares was minimized. Figures 16 and 17 display the results. The $\beta_{1}$ and $C_{1}$ coefficients were determined to be -0.00140 and $7.69 \times 10^{-5}$, respectively. The agreement of $\gamma$ is good, with the largest deviation of $2.6 \%$ occurring at $50^{\circ} \mathrm{C}$ and 4 molal. Next, $30^{\circ} \mathrm{C}(303 \mathrm{~K})$ was inserted into the modified Bromley equation, a plot was obtained comparing the $\gamma$ values to Harned's values at $30^{\circ} \mathrm{C}$. Figure 18 shows the excellent agreement, which verified the method used for the $\mathrm{HCl}$ system. 


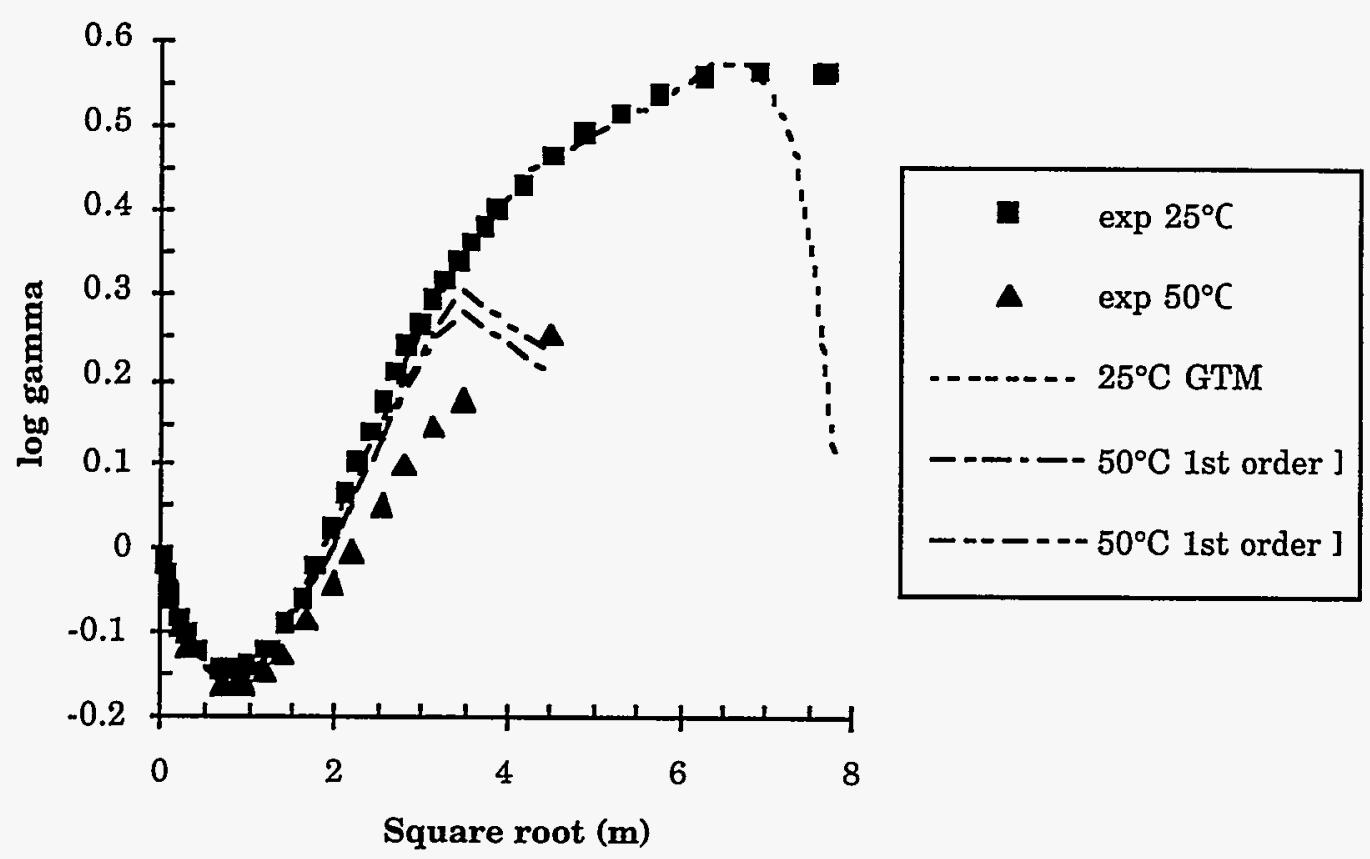

Fig. 14. Calculated $\log \gamma$ with Temperature-Dependence of $A, D$, and E vs. the Experimental Data of Davis and Lemire. Results show the temperature dependence of $A$ and $D$ included in the GTM calculations and of $A$ and $\mathrm{E}$ included in the GTM calculations. Temperatures are 25 and $50^{\circ} \mathrm{C}$.

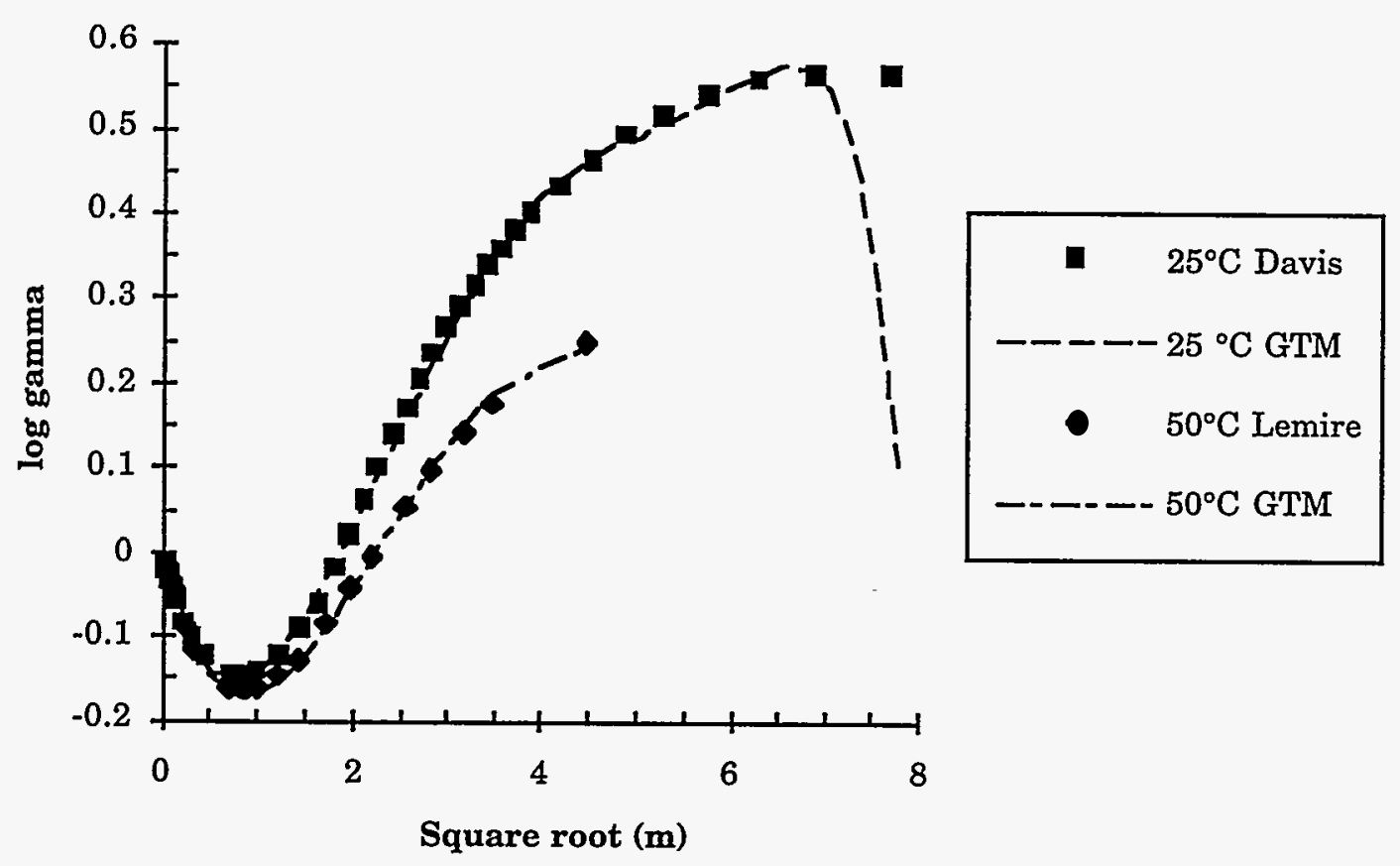

Fig. 15. Calculated $\log \gamma$ with Temperature-Dependence of $A, \beta$, and $C$ vs. the Experimental Data of Davis and Lemire. Temperature-dependences of $A, \beta$, and $C$ are included in the calculations. Temperatures are 25 and $50^{\circ} \mathrm{C}$. 


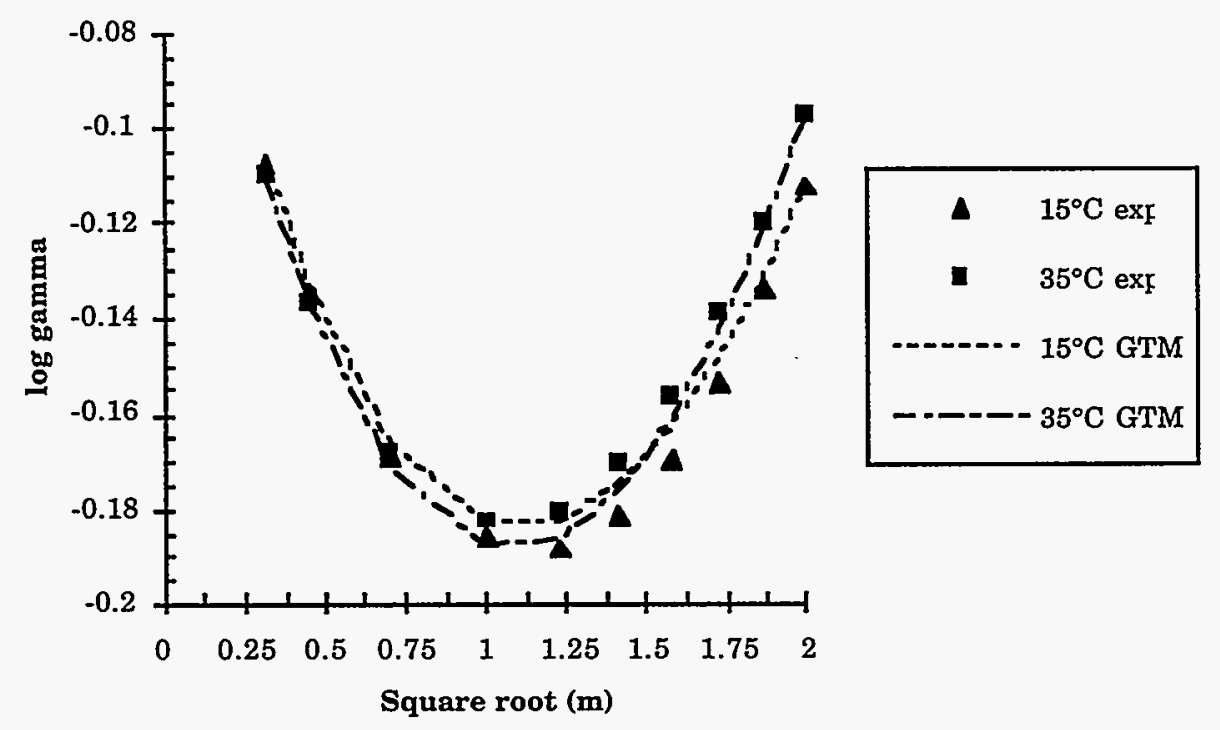

Fig. 16. Comparison of the GTM Equation with $\mathrm{NaCl}$-Water Data at $15^{\circ} \mathrm{C}$ and $35^{\circ} \mathrm{C}$ [HARNED]

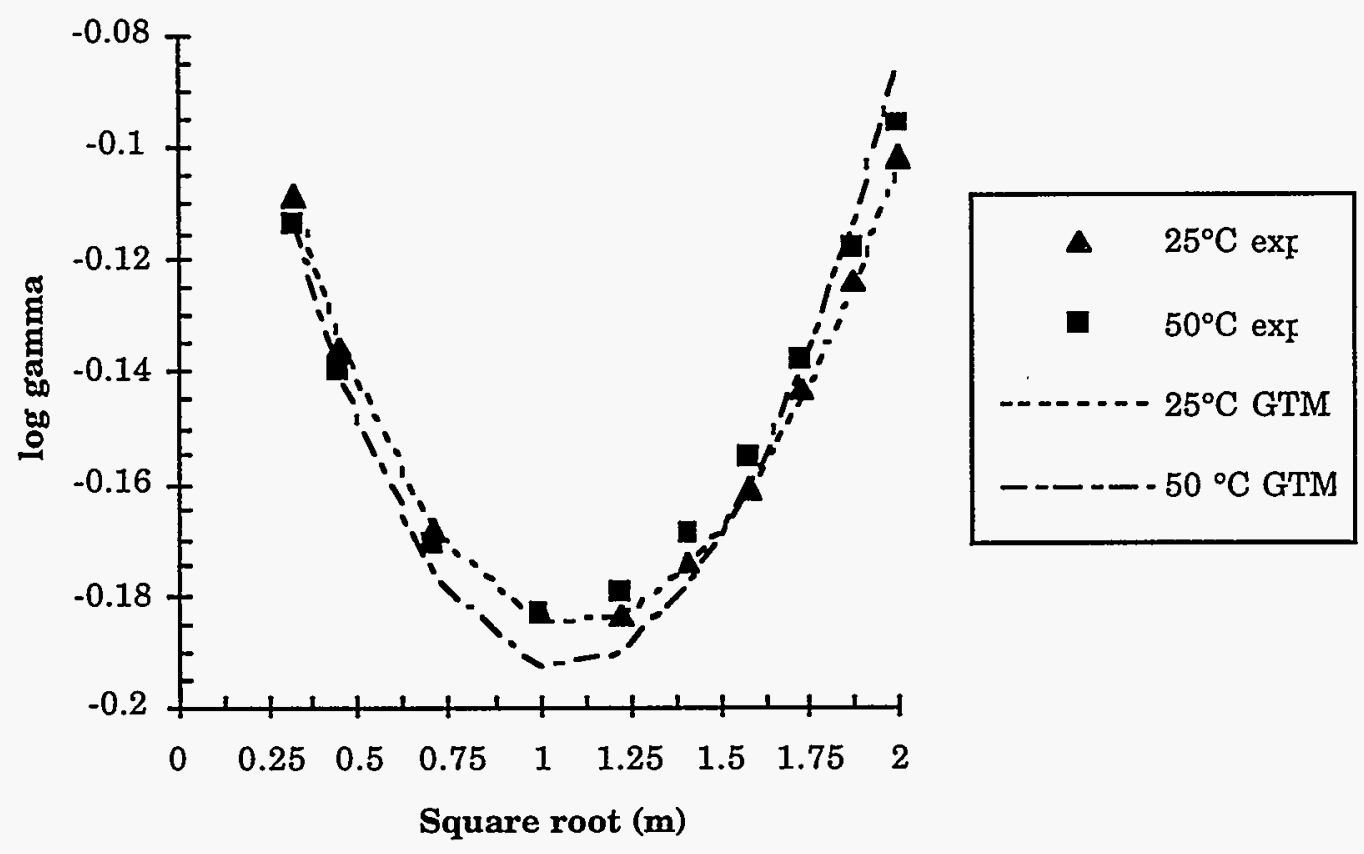

Fig. 17. Comparison of the GTM Equation with NaCl-Water Data at $25^{\circ} \mathrm{C}$ and $50^{\circ} \mathrm{C}$ [HARNED] 


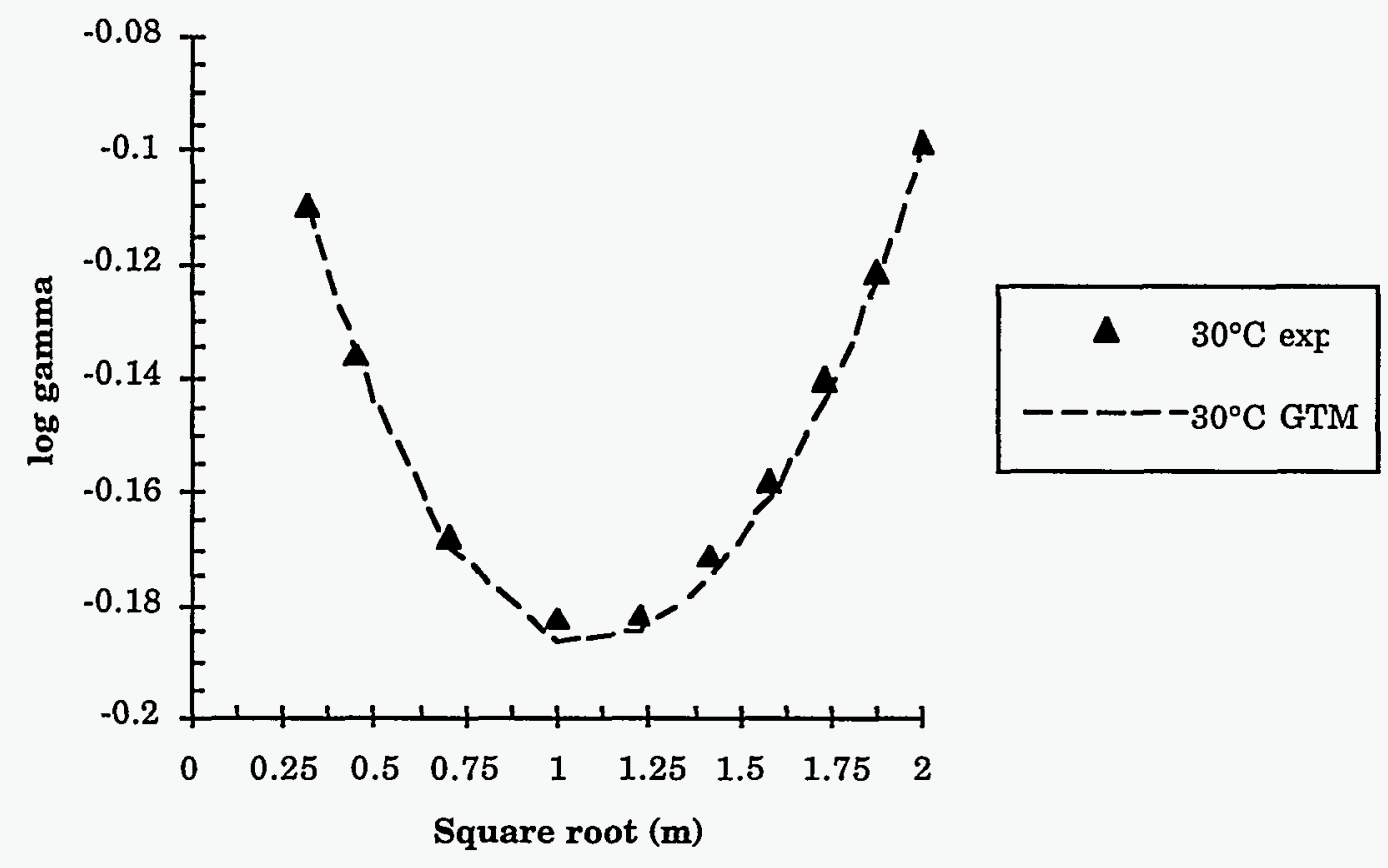

Fig. 18. Calculated $\log \gamma$ for $\mathrm{NaCl}$ at $30^{\circ} \mathrm{C}$ vs. Reported Data [HARNED]

The $\mathrm{HCl}$ activity coefficients reported by Harned and Owens were fit to the GTM equation for temperatures of $15,25,35,45^{\circ} \mathrm{C}$. These coefficients were determined at $25^{\circ} \mathrm{C}$ :

$$
\begin{aligned}
& B=1.5403 \\
& b_{0}=0.09651 \\
& C_{0}=0.0151 \\
& D=-0.0035 \\
& E=0.000364
\end{aligned}
$$

Similarly, a least-squares fit to the reported data was performed to obtain $\beta_{1}$ and $C_{1}$ (Fig. 19 and 20). The values of $\beta_{1}=-0.0004292$ and $C_{1}=-1.812 \times 10^{-5}$ produced an excellent fit with negligible deviation for all data points. To test other temperatures, the calculated $\gamma$ values for $\mathrm{HCl}$ at $30^{\circ} \mathrm{C}$ were compared to the reported values of Harned (Fig. 21); the calculated values agreed very well with the experimental values. The ability for the modified Bromley equation to agree with the experimental data validates this temperature-dependent model. Since the method for calculating activity coefficients at temperatures other than $25^{\circ} \mathrm{C}$ is verified, we turn our attention to predicting the vapor pressures above $\mathrm{HNO}_{3}$-water solutions. 


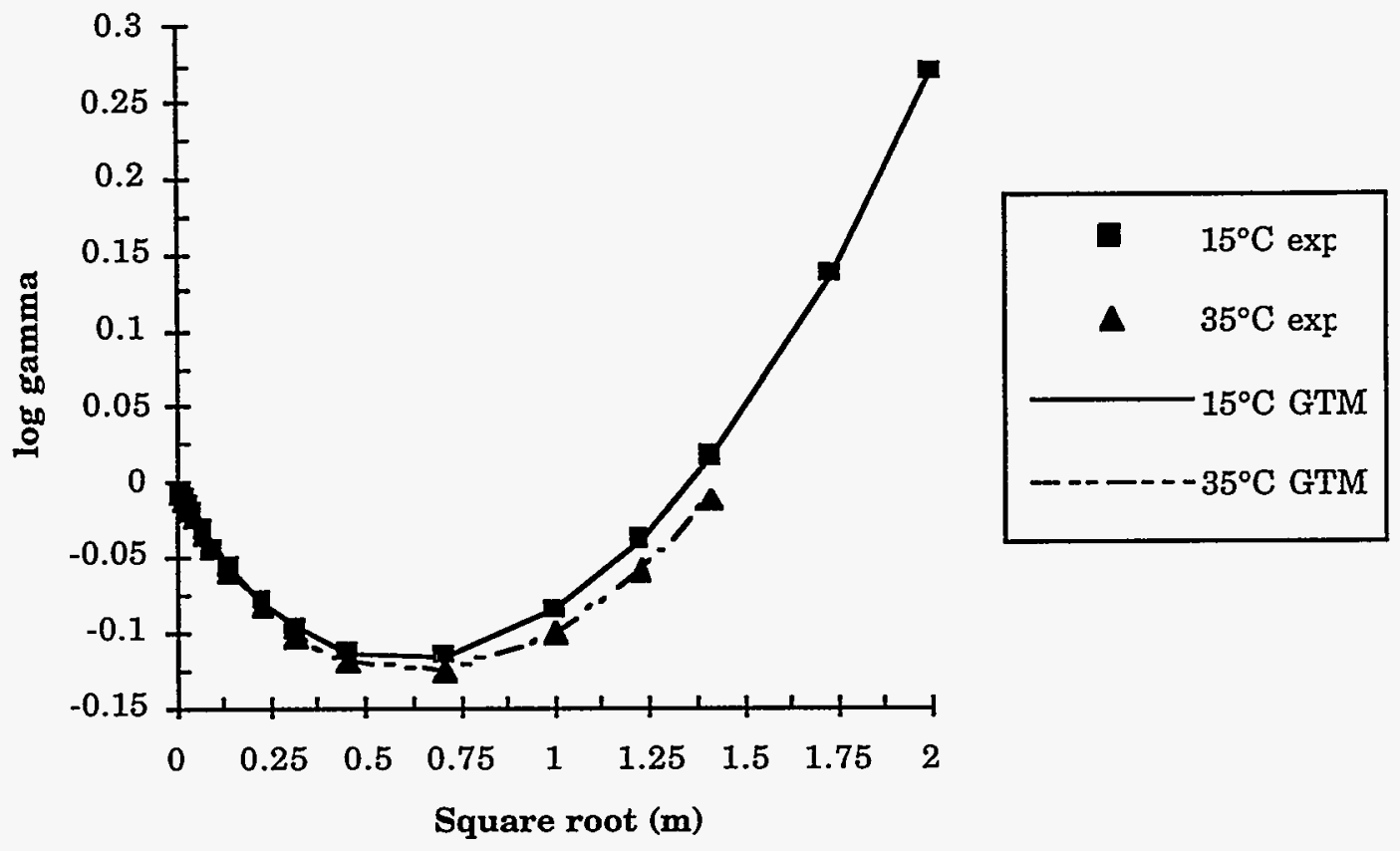

Fig. 19. Comparison of GTM Fit to $\mathrm{HCl}-$ Water Data at $15^{\circ} \mathrm{C}$ and $35^{\circ} \mathrm{C}$ [HARNED]

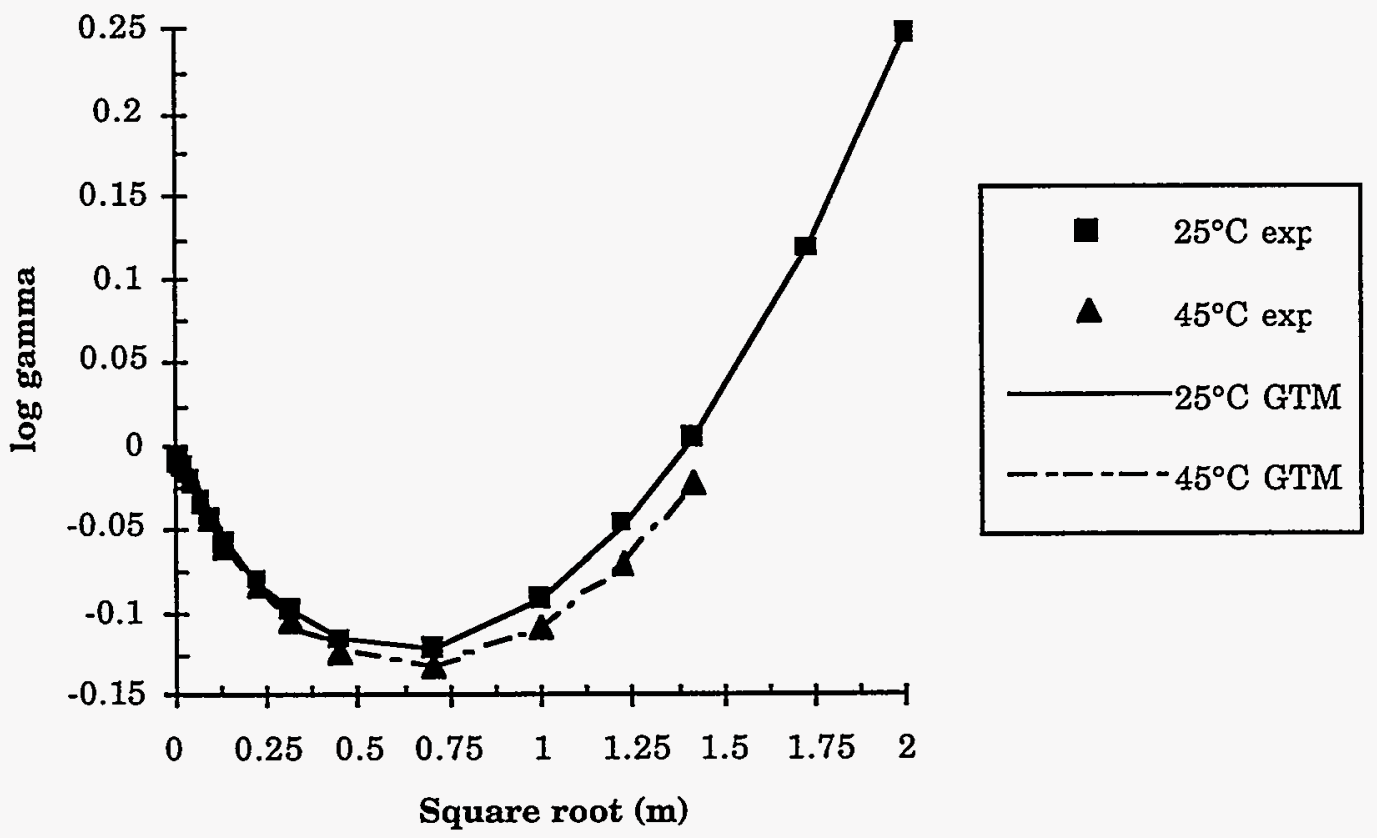

Fig. 20. Comparison of GTM Fit to $\mathrm{HCl}-$ Water Data at $25^{\circ} \mathrm{C}$ and $45^{\circ} \mathrm{C}$ [HARNED] 


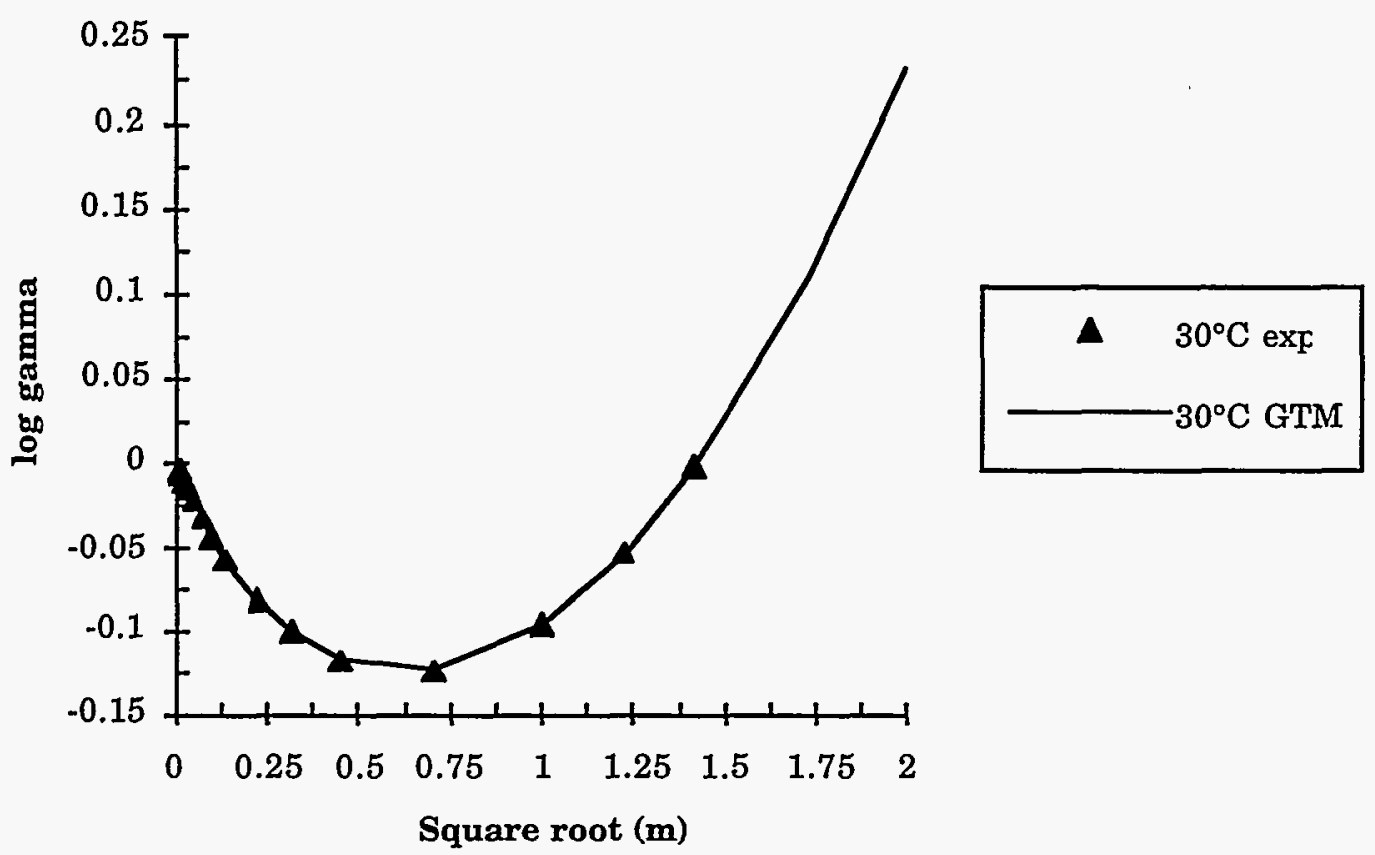

Fig. 21. Agreement of the Calculated $\log \gamma$ for $\mathrm{HCl}$ with Reported Data at $30^{\circ} \mathrm{C}$ [HARNED]

\section{Partial Pressure Calculations}

Lemire [LEMIRE-1985, -1982] reported an equation for relating the activity coefficient of nitric acid to its vapor pressure $(\mathrm{kPa})$ while correcting for standard state.

$$
P_{n}=\frac{P_{n}^{*}\left(m_{n}\right)^{2}\left(\gamma_{n}\right)^{2}}{\left(\gamma^{*} m^{*}\right)^{2}}
$$

where the $\mathrm{n}$ refers to nitric acid and $\left(\gamma^{*} \mathrm{~m}^{*}\right)^{2}$ is the mean activity of nitric acid in $100 \%$ nitric acid with respect to the infinite dilution standard state. Lemire reports $\left(\gamma^{*} \mathrm{~m}^{*}\right)^{2}$ values to be $495 \pm 25$ at $25^{\circ} \mathrm{C}$ and $243 \pm 10$ at $50^{\circ} \mathrm{C}$. By converting the concentrations to molar units, the data were used in the GTM to calculate the water activities at $25^{\circ} \mathrm{C}$. The values for $\mathrm{P}\left(\mathrm{H}_{2} \mathrm{O}\right)$ were computed by Raoult's Law for $25^{\circ} \mathrm{C}$, but the calculations for $\mathrm{P}\left(\mathrm{H}_{2} \mathrm{O}\right)$ at $50^{\circ} \mathrm{C}$ were not included, since the GTM is only able to compute the activity of water at $25^{\circ} \mathrm{C}$. The GTM-generated values for $\gamma$ at $25^{\circ} \mathrm{C}$ and $50^{\circ} \mathrm{C}$ were compared to the published values of Yakimov [YAKIMOV] for the vapor pressures of nitric acidwater systems at $25^{\circ} \mathrm{C}$ and $50^{\circ} \mathrm{C}$. Table 10 summarizes the results. Considering that the errors in calculating $\left(\mathrm{g}^{*} \mathrm{~m}^{*}\right)^{2}$ are estimated to be $\pm 10 \%$, the calculated results agree well with the experimental. All calculated values of $\mathrm{P}\left(\mathrm{HNO}_{3}\right)$ fall within the error of the experimental values, except for the $55.5 \mathrm{wt} \% \mathrm{HNO}_{3}$. In the case of the $\mathrm{P}\left(\mathrm{H}_{2} \mathrm{O}\right)$, the GTM calculated values agree fairly well with Yakimov's experimental data. There is a discrepancy at $71.52 \mathrm{wt} \% \mathrm{HNO}_{3}$, but this may be attributed to the azeotrope that occurs at approximately $16 \underline{\mathrm{M}} \mathrm{HNO}_{3}(62.2 \mathrm{~mol} \%)$. Although the data were limited, results do provide confidence in the accuracy of the GTM to predict the activity of $\mathrm{HNO}_{3}$-water systems at various temperatures and to calculate vapor pressures. 
Various calculations of nitric acid vapor pressure were made using nitric acidsalt mixtures. We found that for a ternary system, the effects of temperature on salt activity coefficients must be accounted for to get an accurate fit to the experimental data. For sodium chloride we found that there is no change in activity coefficient as a function of temperature at low ionic strengths ( $\leq 4 \mathrm{molal}$ ), but there is at higher ones. Other salts show similar behavior. This finding encouraged the modification of the salt contribution to the activity coefficient in a manner similar to that used for nitric acid. Using experimentally determined solution and vapor compositions versus temperature from the literature, Raoult's law is used to calculate activities of nitric acid and water. Through fitting these data and comparing them to GTM calculations at $25^{\circ} \mathrm{C}$, temperature effects on various nitrate salt activities will be collected. This work is ongoing and will be completed in FY 1993.

Table 10. Comparison of Calculated $\mathrm{P}\left(\mathrm{H}_{2} \mathrm{O}\right)$ and $\mathrm{P}\left(\mathrm{HNO}_{3}\right)$ from the Modified GTM to Experimental Data of Yakimov

\begin{tabular}{|c|c|c|c|c|c|c|}
\hline \multicolumn{3}{|c|}{$\left[\mathrm{HNO}_{3}\right]$} & \multicolumn{2}{|c|}{$\mathrm{P}\left(\mathrm{HNO}_{3}\right)$, torr } & \multicolumn{2}{|c|}{$\mathrm{P}\left(\mathrm{H}_{2} \mathrm{O}\right)$, torr } \\
\hline $\mathrm{wt} \%$ & $\underline{M}$ & $m$ & calc. & exp. & calc. & exp. \\
\hline \multicolumn{7}{|l|}{ at $25^{\circ} \mathrm{C}$} \\
\hline $\begin{array}{c}40.25 \\
55.5 \\
71.52\end{array}$ & $\begin{array}{l}7.94 \\
11.7 \\
16.0\end{array}$ & $\begin{array}{l}10.7 \\
19.8 \\
39.8\end{array}$ & $\begin{array}{c}0.132 \\
0.807 \\
5.38\end{array}$ & $\begin{array}{l}0.11 \\
0.7 \\
5.2\end{array}$ & $\begin{array}{l}13.6 \\
8.81 \\
4.93\end{array}$ & $\begin{array}{c}13.20 \\
8.10 \\
3.30\end{array}$ \\
\hline \multicolumn{7}{|l|}{ at $50^{\circ} \mathrm{C}$} \\
\hline $\begin{array}{l}20.28 \\
40.25 \\
55.18\end{array}$ & $\begin{array}{l}3.53 \\
7.78 \\
11.4\end{array}$ & $\begin{array}{l}4.04 \\
10.7 \\
19.5\end{array}$ & $\begin{array}{l}0.046 \\
0.838 \\
4.04\end{array}$ & $\begin{array}{c}a \\
0.75 \\
3.7\end{array}$ & & \\
\hline
\end{tabular}

Below detection limit.

\section{FUTURE PLANS}

The work described in this report covers the first year of a multiyear program. Many of the tasks started this year will be completed in the future. The goal of this project is to complete the design of a remote, criticality-safe-by-geometry evaporator in FY 1995 and to fabricate a pilot plant-scale version of this evaporator in FY 1996. The milestones planned for the next four years are listed in Table 11.

In FY 1993, work will focus on several fronts. First, operation of the laboratory-scale evaporator that was purchased in FY 1992 will continue. Tests are planned that will support both the design of the criticality-safe evaporator and WMO's new evaporator system. These tests will be completed in collaboration with LICON. Second, the modeling work initiated in FY 1992 will be completed. Once completed, this model will be able to predict vapor-phase compositions for a variety of waste stream compositions. Third, using the ideas generated in FY 1992, a conceptual design of the criticality-safe evaporator will be developed. This design, completed in conjunction with LICON, will incorporate ideas generated in laboratory tests. Finally, the design for WMO's low-level waste evaporator will be completed, and purchase of these evaporators will be completed in FY 1993. 
Table 11. Major Milestones, FY 1993 through FY 1996

FY 1993 Solution and equipment tests using laboratory-scale evaporator. Complete modeling of vapor-liquid equilibrium data.

Begin conceptual design of criticality-safe evaporator.

Finalize design and purchase evaporator(s) for WMO.

FY 1994 Continue tests in laboratory-scale evaporator.

Review and provide input on WMO evaporator operations.

Continue design of the criticality-safe evaporator (pilot plant-scale).

FY 1995 Complete design of pilot plant-scale criticality-safe evaporator.

Obtain capital equipment funds for pilot plant-scale evaporator.

FY 1996 Complete fabrication and installation of pilot plant-scale evaporator.

In FY 1994, experiments using the laboratory-scale evaporator will continue. The WMO evaporator will be completely installed this year and operating with actual waste solutions. Daily operation of these units will be monitored, and data collected from their operation will be incorporated into the design of the pilot plant-scale criticality-safe evaporator. The design of this unit, which continued through FY 1994, will be completed in FY 1995. Capital equipment funds for this unit will be secured this year, and fabrication will start in FY 1996. 


\section{ACKNOWLEDGMENTS}

This program was funded by the Vitrification Projects Division (EM-343), Office of Waste Management, Environmental Restoration and Waste Management, DOE-HQ. The authors would like to acknowledge the efforts of Kenneth Chacey, Director of the Vitrification Projects Division, for his continued support of this program. A special acknowledgment also goes to Joel Haugen, DOE-CH, for his energetic support and dedication over the past three years.

The authors wish to express their sincere gratitude to the following people. Their help and understanding led directly to the quality of technical information presented in this report.

Steve Schaus, Westinghouse Hanford Company, for his enthusiastic support and advice.

Rod Williamson, LICON, Inc., for his advice and support since this project was first proposed.

Maxwell Schletter and Hyo No, both from Argonne's Waste Management Operations, for their confidence in our abilities to design and procure an evaporator for their facility. appreciated.

Donna Tipton, whose understanding and skillful preparation of this document is greatly

A special thanks to Bill Williamson for his initial advice and enthusiasm that enabled us to bring this program to fruition. 


\section{REFERENCES}

\section{ALTSHELER}

W. B. Altsheler, E. D. Unger, and P. Kolachov, "Improved Still for Liquid-Vapor Equilibria," Ind. Eng. Chem. $\underline{43}, 2559$ (1951).

ANS

American Nuclear Society, "American National Standard for Nuclear Criticality Safety in Operations with Fissionable Materials Outside Reactors," American Nuclear Society Report ANSI/ANS-8.1-1983 (Revision of ANSI N16.1-1975), LaGrange Park, IL (1983).

\section{BABOIAN}

R. Baboian, Ed., Electrochemical Techniques for Corrosion, NACE, Houston, TX (1977).

\section{BUSHMAKIN}

N. Bushmakin, "Apparatus for Determination of Liquid-Vapor Equilibria," J. Appl. Chem.

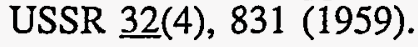

\section{BURGESS}

T. W. Burgess, J. H. Evans, F. L. Peishel, S. L. Schrock, G. E. Smith, and D. MacDonald, Design Guidelines for Remotely Maintained Equipment, Oak Ridge Laboratory Report ORNL/TM-10864, 1988.

\section{CHAIKO-1988A}

D. J. Chaiko, D. R. Fredrickson, L. Reichley-Yinger, and G. F. Vandegrift, "Thermodynamic Modeling of Chemical Equilibria in Metal Extraction," Sep. Sci. Technol. 23(12 \& 13), 1435-1451 (1988).

\section{CHAIKO-1988B}

D. J. Chaiko, P.-K. Tse, and G. F. Vandegrift, Innovations in Materials Processing Using Aqueous, Colloid and Surface Chemistry, F. M. Doyle, S. Raghavan, P. Somasundaran, and G. W. Warren, Eds., The Minerals, Metals, \& Materials Soc., Warrendale, PA, pp. 261-272 (1988).

\section{CHAIKO-1988C}

D. J. Chaiko and G. F. Vandegrift, "A Thermodynamic Model of Nitric Acid Extraction by

Tri-n-Butyl Phosphate," Nucl. Technol. $\underline{82}$, 52-59 (1988).

\section{CHAMBERLAIN}

D. B. Chamberlain, R. A. Leonard, J. C. Hoh, E. C. Gay, D. G. Kalina, and G. F. Vandegrift, TRUEX Hot Demonstration: Final Report, Argonne National Laboratory Report ANL-89/37 (April 1990).

COLE

H. S. Cole, "Corrosion of Austenitic Stainless Steel Alloys Due to $\mathrm{HNO}_{3}$-HF Mixtures," Allied Chemical Idaho Chemical Programs, ICP-1036 (October 1974).

CRAIG

B. D. Craig, Handbook of Corrosion Data, ASM International, Metals Park, OH (1989).

\section{CREMEANS}

George Cremeans, "Final Disposition of TMI Unit 2 Accident-Generated Water," Nucl.

Technol. $\underline{87}$ (Dec. 1989). 


\section{REFERENCES (contd)}

CROFF

A. G. Croff and C. W. Alexander, Decay Characteristics of Once-through LWR and LMFBR Spent Fuels, High Level Wastes, and Fuel-Assembly Structured Material Wastes, Oak Ridge National Laboratory Report ORNL/TM-7431 (November 1980).

CURRIE

L. A. Currie, "Limits for Qualitative Detection and Quantitative Determination," Anal. Chem. $\underline{3}, 586$ (1968).

EVANS

S. Evans and E. L. Koehler, "Use of Polarization Methods in the Determination of the Rate of Corrosion of Aluminum Alloys in Anaerobic Media", J. Elec. Chem. Soc., 108(6), 509-514 (1961).

DAVIS

W. Davis, Jr., and H. J. De Brunt, "New Activity Coefficients of 0-100 Per Cent Aqueous Nitric Acid," J. Inorg. Nucl. Chem. 26, 1069 (1964).

GORODETSKI

I. Y. Gorodetskii, V. M. Olevskii, R. P. Levitanaite, and L. A. Legochkina, "Apparatus for

Determining Equilibrium Between Liquid and Vapour," Russian J. Phys. Chem. 38(11), 1497

(1964).

GRANT

K. Grant, private communication, LICON Corp., Inc. (1992).

HALA

E. Hála, J. Pick, V. Fried, and O. Vilím, Vapour-Liquid Equilibrium, Pergamon, Oxford (1967).

\section{HARNED}

H. S. Harned and B. B. Owens, The Physical Chemistry of Electrolyte Solutions, 3rd ed., Reinhold Pub., New York (1958).

\section{HARPER}

C. A. Harper, Ed., Handbook of Plastics and Elastomers, McGraw-Hill, New York (1975).

\section{HOFFMAN}

T. L. Hoffman et al., Evaluation of Stainless Steel Tank Corrosion in ICPP High-Level Radioactive Waste Service, Exxon Idaho Nuclear Company, ENICO-1131 (Apr. 1983).

\section{HORWITZ-1985}

E. P. Horwitz, D. G. Kalina, H. Diamond, G. F. Vandegrift, and W. W. Schulz, "TRUEX Process--A Process for the Extraction of the Transuranic Elements from Nitric Acid Wastes Utilizing Modified PUREX Solvent," Solvent Extr. Ion Exch. 3(1-2), 75-109 (1985).

\section{HORWITZ-1986}

E. P. Horwitz and W. W. Schulz, "Application of the TRUEX Process to the Decontamination of Nuclear Waste Streams," Inter. Solvent Extraction Conf., Munich, September 11-16, 1986, Vol. I, pp. 81-90 (1986). 


\section{REFERENCES (contd)}

\section{HORWITZ-1988}

E. P. Horwitz, R. Chiarizia, and R. C. Gatrone, "Behavior of Americium in the Strip Stages of the TRUEX Process," Solvent Extr. Ion Exch. $\underline{6}, 93$ (1988).

\section{KAESCHE}

H. Kaesche and N. Hackerman, "Corrosion Inhibition by Organic Amines," J. Elec. Chem. Soc. 105(4), 191-198 (1958).

KRING

C. T. Kring and S. L. Schrock, "Remote Maintenance 'Lessons Learned' on Prototypical Reprocessing Equipment," American Nuclear Society, LaGrange, IL, CONF-901101--34 (1990).

\section{LEMIRE-1982}

R. J. Lemire and C. P. Brown," Component Activities in the System Thorium Nitrate-Nitric Acid-Water at $25^{\circ} \mathrm{C}, "$ J. Soln. Chem. 11, 203 (1982).

\section{LEMIRE-1985}

R. J. Lemire, C. P. Brown, and A. B. Campbell, "Vapor Pressures of Nitric Acid and Water in the Systems $\mathrm{HNO}_{3}-\mathrm{H}_{2} \mathrm{O}$ and $\mathrm{HNO}_{3}-\mathrm{Th}\left(\mathrm{NO}_{3}\right)_{4}-\mathrm{H}_{2} \mathrm{O}$ at $50^{\circ} \mathrm{C}$," J. Chem. Eng. Data $\underline{30}, 421$ (1985).

\section{LEVINE}

I. N. Levine, Physical Chemistry, 2nd ed., McGraw-Hill, New York, pp. 246-257 (1983).

\section{LEONARD}

R. A. Leonard, M. C. Regalbuto, D. B. Chamberlain, and G. F. Vandegrift, "A New Model for Solvent Extraction in Columns," Sep. Sci. Technol. 25(13-15), 1689-1707 (1990).

\section{LINDSTROM}

R. M. Lindstrom, "Accuracy in Activation Analysis: Count Rate Effects," Proc. 4th Int. Conf. Nuclear Methods in Envir. \& Energy Res., Columbia, MO, April 14, 1980, J. R. Vogt, Ed., pp. 25-35 (1980).

\section{MARTIN}

R. L. Martin, "Potentiodynamic Polarization Measurements in the Field," Mat. Per. $\underline{18(3),}$ 41-50 (1979).

MIZIA

R. Mizia, personal communication, Idaho Chemical Processing Plant (May 1992).

\section{MORRIS}

P. E. Morris and R. C. Scarberry, "Predicting Corrosion Rates with the Potentistat," Corr. 28(12), 444-452 (1972).

NAGY

Z. Nagy, "DC Electrochemical Techniques for the Measurement of Corrosion Rates," Modern Aspects of Electrochemistry, Vol. 25, Chap. 3, New York (1993).

\section{NASH}

K. L. Nash, R. C. Gatrone, G. A. Clark, P. G. Rickert, and E. P. Horwitz, "Hydrolytic and Radiolytic Degradation of OøD(iB)CMPO: Continuing Studies," Sep. Sci. Technol. 23, 1355-1372 (1988). 


\section{REFERENCES (contd)}

\section{OWENSBY}

G. S. Owensby, C. A. Plank, and W. L. S. Laukhuf, "Vapor-Liquid Equilibria of the Trimethyl Borate (1)-Trichloroethylene (2) System," J. Chem. Eng. Data 34, 213 (1989).

PAXTON

H. C. Paxton, J. T. Thomas, D. Callihan, and E. B. Johnson, "Critical Dimensions of Systems Containing ${ }^{235} \mathrm{U},{ }^{239} \mathrm{Pu}$, and ${ }^{233} \mathrm{U}$, " U.S. Atomic Energy Commission Report TID-7028, Washington, DC (1964).

PERRY

R. H. Perry et al., Eds., Perry's Chemical Engineers' Handbook, 6th ed., McGraw-Hill, New York (1984).

PITZER

K. S. Pitzer, Activity Coefficients in Electrolyte Solutions, CRC Press, Boca Raton, FL (1991).

RALLS

K. M. Ralls, T. H. Courtney, and J. Wulff, Introduction to Materials Science and Engineering, Wiley \& Sons, New York (1976).

REGALBUTO

M. C. Regalbuto, B. Misra, D. B. Chamberlain, R. A. Leonard, and G. F. Vandegrift, The Monitoring and Control of TRUEX Processes. Volume One -- The Use of Sensitivity Analysis to Determine Key Process Variables and Their Control Bound, Argonne National Laboratory Report ANL-92/7 (1992).

SCHREIBER

S. B. Schreiber, Corrosion Study of Simulated Evaporator Components, Los Alamos National Laboratory Report LA-11566-MS (July 1989).

SCHULZ

W. W. Schulz and E. P. Horwitz, "Potential Applications of the TRUEX Process," in Waste Management '86, Proc. Symp. on Waste Management, Tucson, AZ, March 2-6, 1986, Vol. 1, p. 303 (1986).

SCHWEITZER

P. A. Schweitzer, Corrosion Resistance Tables: Metals, Plastics, Nonmetallics and Rubbers, Marcel Dekker, New York (1976.)

SIMONZADEH

N. Simonzadeh, A. M. Crabtree, L. E. Trevorrow, and G. F. Vandegrift, Radiolysis and

Hydrolysis of TRUEX-NPH Solvent, Argonne National Laboratory Report ANL-90/14 (1992)

\section{STEINDLER}

M. J. Steindler et al., Nuclear Technology Programs Semiannual Progress Report April-

September 1990, Argonne National Laboratory Report ANL-92/25 (1992).

\section{STERN}

M. Stern, "The Electrochemical Behavior, Including Hydrogen Overpotential, of Iron in Acid Environments," J. Elec. Chem. Soc. 112(11), 609-616 (1965). 
REFERENCES (contd)

TSE

P.-K. Tse, L. Reichley-Yinger, and G. F. Vandegrift, "TRUEX Process Solvent Cleanup with

Solid Sorbents," Sep. Sci. Technol. 25(13-15), 1763-1775 (1990).

UHLIG

H. H. Uhlig, Corrosion and Corrosion Control, Wiley \& Sons, New York (1963).

VILLEMEZ

R. Villemez and C. Millet, "Evaluation of Alloys for Nuclear Waste Evaporators", Mat. Per. 19(7), 19-25 (1980).

WICHTERLE-1973

I. Wichterle, J. Polak, and E. Hala, Vapor-Liquid Equilibrium Data Bibliography, Elsevier, Amsterdam (1973).

WICHTERLE-1976

I. Wichterle, J. Polak, and E. Hala, Vapor-Liquid Equilibrium Data Bibliography Supplement I, Elsevier, Amsterdam (1976).

WICHTERLE-1979

I. Wichterle, J. Polak, and E. Hala, Vapor-Liquid Equilibrium Data Bibliography Supplement

II, Elsevier, Amsterdam (1979).

WICHTERLE-1982

I. Wichterle, J. Polak, and E. Hala, Vapor-Liquid Equilibrium Data Bibliography Supplement III, Elsevier, Amsterdam (1982).

WICHTERLE-1985

I. Wichterle, J. Polak, and E. Hala, Vapor-Liquid Equilibrium Data Bibliography Supplement $I V$, Elsevier, Amsterdam (1985).

WILDING

M. W. Wilding and B. E. Paige, Survey on Corrosion of Metals and Alloys in Solutions

Containing Nitric Acid, Allied Chemical Idaho Chemical Programs, ICP-1107 (Dec. 1976).

YAKIMOV

M. A. Yakomov,"Investigation of Heterogeneous Equilibria in the Ternerary System $\mathrm{UO}_{2}\left(\mathrm{NO}_{3}\right)_{2}-\mathrm{HNO}_{3}-\mathrm{H}_{2} \mathrm{O}$. IV. Solution-Vapor Equilibrium of the System Uranyl Nitrate-

Nitric Acid-Water at 25 and $50^{\circ} \mathrm{C}$," Radiokhimiya 6, 552 (1964).

YAMOMOTO

Y. Yamomoto et al., Design and Operation of Evaporators for Radioactive Wastes, International Atomic Energy Agency, Vienna (1968).

ZEMAITIS

J. F. Zemaitis Jr., Handbook of Aqueous Electrolyte Thermodynamics: Theory and Applications, Design Institute for Physical Property Data, New York (1986). 


\section{APPENDIX A}

\section{Solubility of Nitrate Salts in Aqueous Nitric Acid}

Although the LICON evaporator can operate smoothly with small amounts of solids in solution, it is preferable to operate it at a solution composition that does not precipitate solids. To accomplish this, it is essential to know the solubility of salts as a function of solution composition. Some of the nitrate salts important to the concentrating of solutions from treatment of Hanford tank wastes are aluminum, calcium, iron, lanthanum, nickel, samarium, sodium, and uranium. Solubility data were obtained for each of these salts as a function of acid concentration at constant temperatures. Solubility data for other nitrate salts (such as other rare earths and bismuth) and fluoride, sulfate, oxalate, and phosphate salts will be collected in the future. Table A-1 lists the nine figures that show solubility data for various nitrate salts to aid the reader in finding information in this appendix. Table A-2 lists the specific tables that contain the data used to generate the figures. For clarity all of the data tables were moved to the end of the appendix.

Table A-1. List of Systems Presented in Figure Format in Appendix A

\begin{tabular}{|c|c|c|}
\hline Number & Title & Page \\
\hline A-1. & $\begin{array}{l}\text { Solubility of } \mathrm{Al}^{3+}, \mathrm{Ca}^{2+}, \mathrm{Fe}^{3+}, \mathrm{La}^{3+}, \mathrm{Na}^{+}, \mathrm{Ni}^{2+}, \mathrm{Sm}^{3+} \text {, and } \mathrm{UO}_{2}{ }^{2+} \text { Nitrate Salts } \\
\text { in Aqueous Nitric Acid at } 25^{\circ} \mathrm{C}\end{array}$ & 60 \\
\hline A-2. & $\begin{array}{l}\text { Solubility of } \mathrm{Al}^{3+}, \mathrm{Ca}^{2+}, \mathrm{La}^{3+}, \mathrm{Na}^{+} \text {, and } \mathrm{Sm}^{3+} \text { Nitrate Salts in Aqueous Nitric } \\
\text { Acid at } 25^{\circ} \mathrm{C}\end{array}$ & 61 \\
\hline A-3. & $\begin{array}{l}\text { Comparison of Solubilities for Aluminum and Sodium Nitrate in Aqueous } \\
\text { Nitric Acid }\end{array}$ & 61 \\
\hline A-4. & Solubility of $\mathrm{Ca}\left(\mathrm{NO}_{3}\right)_{2}$ in Aqueous Nitric Acid at 25,50 , and $60^{\circ} \mathrm{C}$ & 62 \\
\hline A-5. & Solubility of $\mathrm{La}\left(\mathrm{NO}_{3}\right)_{3}$ in Aqueous Nitric Acid at 25 and $50^{\circ} \mathrm{C}$ & 63 \\
\hline A-6. & Solubility of $\mathrm{NaNO}_{3}$ in Aqueous Nitric Acid at $25,35,50$, and $75^{\circ} \mathrm{C}$ & 63 \\
\hline A-7. & Solubility of $\mathrm{Sm}\left(\mathrm{NO}_{3}\right)_{3}$ in Aqueous Nitric Acid at 25 and $50^{\circ} \mathrm{C}$ & 64 \\
\hline A-8. & Solubility of $\mathrm{UO}_{2}\left(\mathrm{NO}_{3}\right)_{2}$ in Aqueous Nitric Acid at $25,49.1$, and $50^{\circ} \mathrm{C}$ & 64 \\
\hline A-9. & $\begin{array}{l}\text { Solubility of } \mathrm{UO}_{2}\left(\mathrm{NO}_{3}\right)_{2} \text { in the Presence of a Second Nitrate Salt in } \\
1.5 \underline{\mathrm{M}} \mathrm{HNO}_{3} \text { at } 25^{\circ} \mathrm{C}\end{array}$ & 65 \\
\hline
\end{tabular}

The solubilities reported in the literature were generally presented as grams of salt, acid, and water per 100 grams of saturated solution, but they are more useful in units of molarity. The solution density is needed to convert the literature data to molarity; it was not given in the literature, so it was calculated. The solution density of 100 grams of saturated solution can be estimated using

$$
\rho=\frac{100 \mathrm{~g}}{\mathrm{~V}}
$$

The solution volume can be calculated using the same equation used in the Generic TRUEX Model (GTM):

$$
\mathrm{V}=\mathrm{V}_{\mathrm{H}_{2} \mathrm{O}}+\sum_{\mathrm{i}} \mathrm{n}_{\mathrm{i}} \mathrm{V}_{\varnothing, \mathrm{i}}
$$

where $\mathrm{V}_{\mathrm{H}_{2} \mathrm{O}}$ is the volume of water, $\mathrm{n}$ is the moles of solute, and $\mathrm{V}_{\varnothing}$ is the apparent molar volume 
Table A-2. List of Systems Presented in Table Format in Appendix A

\begin{tabular}{|c|c|c|}
\hline No. & Title & Page \\
\hline A-3. & Apparent Molar Volumes (AMV) for Selected Ions & 60 \\
\hline A-4. & Solubility Data for $\mathrm{Al}\left(\mathrm{NO}_{3}\right)_{3}$ in Nitric Acid-Water at $25^{\circ} \mathrm{C}$ & 65 \\
\hline A-5. & Solubility Data for $\mathrm{Ca}\left(\mathrm{NO}_{3}\right)_{2}$ in Nitric Acid-Water at $25^{\circ} \mathrm{C}$ & 66 \\
\hline A-6. & Solubility Data for $\mathrm{Fe}\left(\mathrm{NO}_{3}\right)_{3}$ in Nitric Acid-Water at $25^{\circ} \mathrm{C}$ & 66 \\
\hline A-7. & Solubility Data for $\mathrm{La}\left(\mathrm{NO}_{3}\right)_{3}$ in Nitric Acid-Water at $25^{\circ} \mathrm{C}$ & 67 \\
\hline A-8. & Solubility Data for $\mathrm{NaNO}_{3}$ in Nitric Acid-Water at $25^{\circ} \mathrm{C}$ & 67 \\
\hline A-9. & Solubility Data for $\mathrm{Ni}\left(\mathrm{NO}_{3}\right)_{2}$ in Nitric Acid-Water at $25^{\circ} \mathrm{C}$ & 68 \\
\hline A-10. & Solubility Data for $\operatorname{Sm}\left(\mathrm{NO}_{3}\right)_{3}$ in Nitric Acid-Water at $25^{\circ} \mathrm{C}$ & 69 \\
\hline A-11. & Solubility Data for $\mathrm{UO}_{2}\left(\mathrm{NO}_{3}\right)_{2}$ in Nitric Acid-Water at $25^{\circ} \mathrm{C}$ & 70 \\
\hline A-12. & Solubility Data for $\mathrm{Al}\left(\mathrm{NO}_{3}\right)_{3}$ in Nitric Acid-Water at $20^{\circ} \mathrm{C}$ & 70 \\
\hline A-13. & Solubility Data for $\mathrm{Al}\left(\mathrm{NO}_{3}\right)_{3}$ in Nitric Acid-Water at $40^{\circ} \mathrm{C}$ & 71 \\
\hline A-14. & Solubility Data for $\mathrm{Al}\left(\mathrm{NO}_{3}\right)_{3}$ in Nitric Acid-Water at $60^{\circ} \mathrm{C}$ & 71 \\
\hline A-15. & Solubility Data for $\mathrm{NaNO}_{3}-\mathrm{KNO}_{3}$-Water-Nitric Acid at $25^{\circ} \mathrm{C}$ & 71 \\
\hline A-16. & Solubility Data for $\mathrm{Ca}\left(\mathrm{NO}_{3}\right)_{2}-\mathrm{Sr}\left(\mathrm{NO}_{3}\right)_{2}$ in Nitric Acid-Water at $25^{\circ} \mathrm{C}$ & 72 \\
\hline A-17. & Solubility Data for $\mathrm{Fe}\left(\mathrm{NO}_{3}\right)_{3}-\mathrm{Th}\left(\mathrm{NO}_{3}\right)_{4}$ in Nitric Acid-Water at $20^{\circ} \mathrm{C}$ & 72 \\
\hline A-18. & Solubility Data for $\mathrm{UO}_{2}\left(\mathrm{NO}_{3}\right)_{2}-\mathrm{Mg}\left(\mathrm{NO}_{3}\right)_{2}$ in Nitric Acid-Water at $25^{\circ} \mathrm{C}$ & 73 \\
\hline A-19. & Solubility Data for $\mathrm{UO}_{2}\left(\mathrm{NO}_{3}\right)_{2}-\mathrm{Ca}\left(\mathrm{NO}_{3}\right)_{2}$ in Nitric Acid-Water at $25^{\circ} \mathrm{C}$ & 73 \\
\hline A-20. & Solubility Data for $\mathrm{UO}_{2}\left(\mathrm{NO}_{3}\right)_{2}-\mathrm{Cu}\left(\mathrm{NO}_{3}\right)_{2}$ in Nitric Acid-Water at $25^{\circ} \mathrm{C}$ & 74 \\
\hline A-21. & Solubility Data for $\mathrm{Ca}\left(\mathrm{NO}_{3}\right)_{2}$ in Nitric Acid-Water at $25^{\circ} \mathrm{C}$ & 74 \\
\hline A-22. & Solubility Data for $\mathrm{Ca}\left(\mathrm{NO}_{3}\right)_{2}$ in Nitric Acid-Water at $50^{\circ} \mathrm{C}$ & 75 \\
\hline A-23. & Solubility Data for $\mathrm{Ca}\left(\mathrm{NO}_{3}\right)_{2}$ in Nitric Acid-Water at $50^{\circ} \mathrm{C}$ & 75 \\
\hline A-24. & Solubility Data for $\mathrm{Ca}\left(\mathrm{NO}_{3}\right)_{2}$ in Nitric Acid-Water at $60^{\circ} \mathrm{C}$ & 76 \\
\hline A-25. & Solubility Data for $\mathrm{La}\left(\mathrm{NO}_{3}\right)_{3}$ in Nitric Acid-Water at $25^{\circ} \mathrm{C}$ & 76 \\
\hline A-26. & Solubility Data for $\mathrm{La}\left(\mathrm{NO}_{3}\right)_{3}$ in Nitric Acid-Water at $50^{\circ} \mathrm{C}$ & 77 \\
\hline A-27. & Solubility Data for $\mathrm{NaNO}_{3}$ in Nitric Acid-Water at $35^{\circ} \mathrm{C}$ & 77 \\
\hline A-28. & Solubility Data for $\mathrm{NaNO}_{3}$ in Nitric Acid-Water at $50^{\circ} \mathrm{C}$ & 78 \\
\hline A-29. & Solubility Data for $\mathrm{NaNO}_{3}$ in Nitric Acid-Water at $75^{\circ} \mathrm{C}$ & 78 \\
\hline A-30. & Solubility Data for $\mathrm{Sm}\left(\mathrm{NO}_{3}\right)_{3}$ in Nitric Acid-Water at $25^{\circ} \mathrm{C}$ & 78 \\
\hline A-31. & Solubility Data for $\mathrm{Sm}\left(\mathrm{NO}_{3}\right)_{3}$ in Nitric Acid-Water at $50^{\circ} \mathrm{C}$ & 79 \\
\hline A-32. & Solubility Data for $\mathrm{UO}_{2}\left(\mathrm{NO}_{3}\right)_{2}$ in Nitric Acid-Water at $25^{\circ} \mathrm{C}$ & 79 \\
\hline A-33. & Solubility Data for $\mathrm{UO}_{2}\left(\mathrm{NO}_{3}\right)_{2}$ in Nitric Acid-Water at $49.1^{\circ} \mathrm{C}$ & 80 \\
\hline A-34. & Solubility Data for $\mathrm{UO}_{2}\left(\mathrm{NO}_{3}\right)_{2}$ in Nitric Acid-Water at $50^{\circ} \mathrm{C}$ & 81 \\
\hline
\end{tabular}

(AMV) of the solute of species i. Note that the volume of water was determined by dividing the mass of water for a given solution by the density of water at $25^{\circ} \mathrm{C}(0.99707 \mathrm{~g} / \mathrm{mL}$ [WEAST]). The product $\mathrm{nV}_{\phi}$ is the volume of the solute. For the nitric acid-water-nitrate salt system, water is considered the solvent and salt and acid are the solutes. Values for apparent molar volumes of cations and anions at $25^{\circ} \mathrm{C}$ are listed in Table A-3. The AMV for $\mathrm{H}^{+}$was set to zero as the reference AMV. Since the AMV's were only available for $25^{\circ} \mathrm{C}$, only the solubility data at $25^{\circ} \mathrm{C}$ were converted to molar units. The experimental data, weight percents of nitric acid and nitrate salt, calculated densities, and molar concentrations of nitric acid plus salts are listed in the various data tables.

The molarities of various salts are plotted versus nitric acid concentration in Figs. A-1 and -2 . They show that aluminum nitrate is the least soluble salt under consideration. Aluminum and sodium nitrate salts are present in many raffinate streams from the TRUEX process in concentrations that range between $0.1-1 \underline{\mathrm{M}}$. These streams also contain high concentrations of nitric acid $(0.5-8 \underline{\mathrm{M}})$. The 
Table A-3. Apparent Molar

Volumes (AMV)

for Selected Ions

\begin{tabular}{cc}
\multicolumn{3}{c}{ for Selected Ions } \\
\hline Ion & $\begin{array}{c}\mathrm{AMV} \\
(\mathrm{mL} / \mathrm{mol})\end{array}$ \\
\hline $\mathrm{Al}^{3+}$ & -45.3 \\
$\mathrm{Ca}^{2+}$ & -17.8 \\
$\mathrm{Fe}^{3+}$ & -43.7 \\
$\mathrm{La}^{3+}$ & -39.1 \\
$\mathrm{Na}^{+}$ & -1.2 \\
$\mathrm{Ni}^{2+}$ & -29.5 \\
$\mathrm{Sm}^{3+}$ & -42.33 \\
$\mathrm{UO}_{2}^{2+}$ & 15.91 \\
$\mathrm{NO}_{3}{ }^{-}$ & 29.5 \\
\hline
\end{tabular}

solubility of aluminum in them will probably limit the degree to which the solution can be concentrated in the evaporator. Other TRUEX process and waste streams are dilute in both nitric acid $(0.02-0.2 \underline{\mathrm{M}})$ and nitrate salts $\left(10^{-10}-10^{-3} \underline{\mathrm{M}}\right)$, so large volume reductions can be expected.

Solubility data with solution densities for aluminum nitrate were also available at 20,40 and $60^{\circ} \mathrm{C}$. These data, including the $25^{\circ} \mathrm{C}$ data for aluminum and sodium nitrate plotted in Figs. A-1 and A-2, are plotted in Fig. A-3. From this figure it can be seen that the solubility of aluminum nitrate is less than sodium nitrate for nitric acid concentrations less than $7 \underline{\mathrm{M}}$. These data also show that solubility increases as the solution temperature increases.

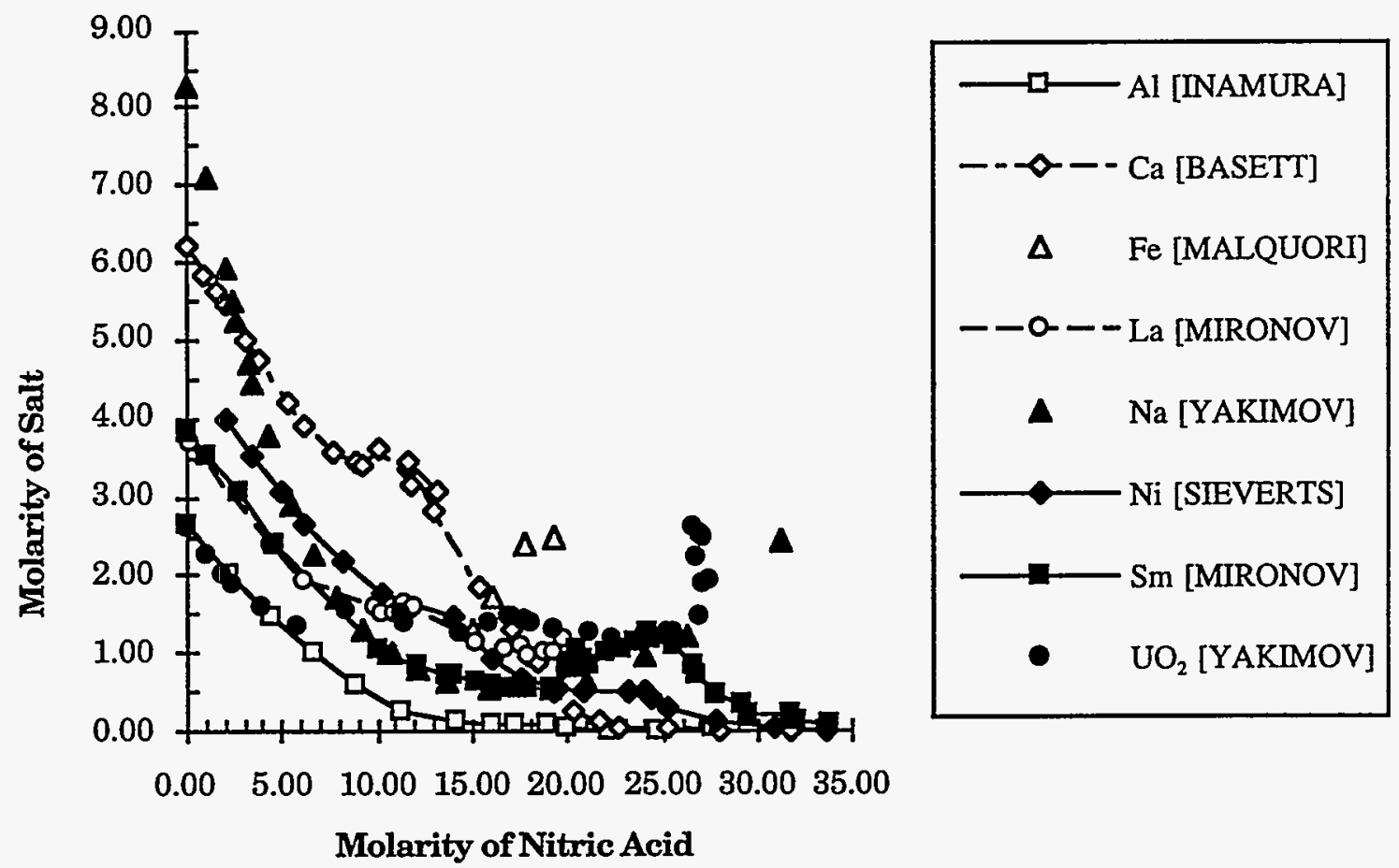

Fig. A-1. Solubility of $\mathrm{Al}^{3+}, \mathrm{Ca}^{2+}, \mathrm{Fe}^{3+}, \mathrm{La}^{3+}, \mathrm{Na}^{+}, \mathrm{Ni}^{2+}, \mathrm{Sm}^{3+}$, and $\mathrm{UO}_{2}^{2+}$ Nitrates in Aqueous Nitric Acid at $25^{\circ} \mathrm{C}$ 


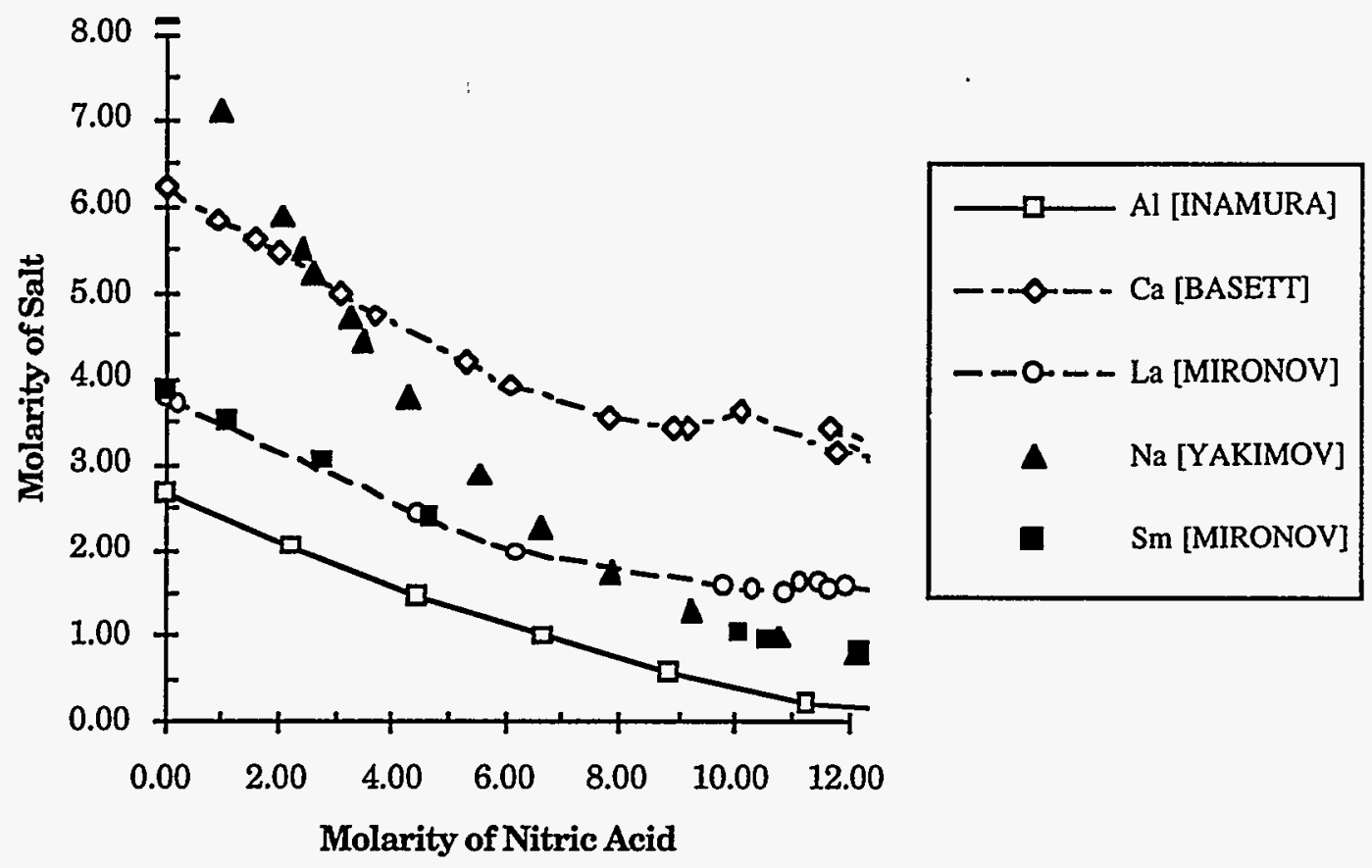

Fig A-2. Solubility of $\mathrm{Al}^{3+}, \mathrm{Ca}^{2+}, \mathrm{La}^{3+}, \mathrm{Na}^{+}$, and $\mathrm{Sm}^{3+} \mathrm{Nitrates}$ in Aqueous Nitric Acid at $25^{\circ} \mathrm{C}$

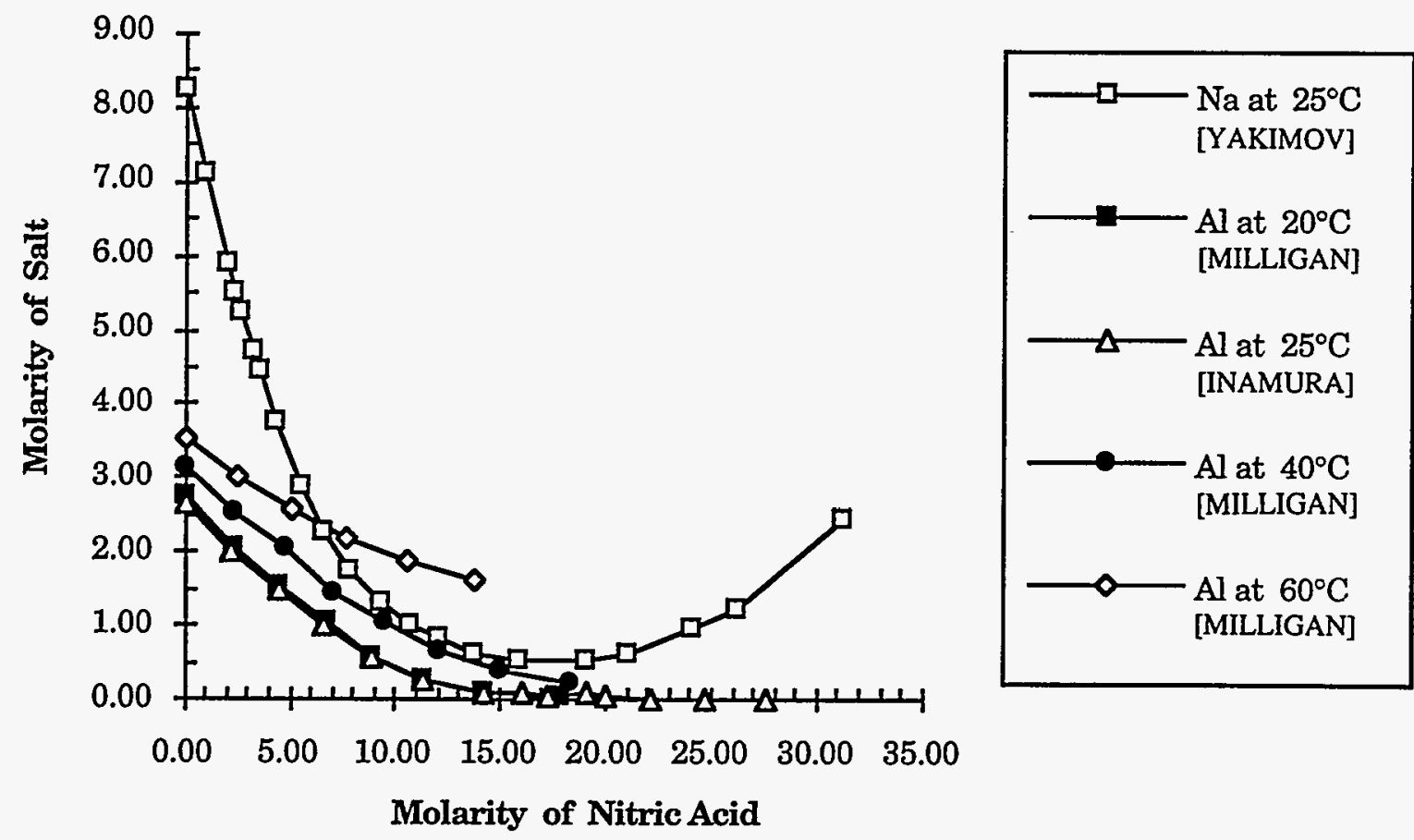

Fig. A-3. Comparison of Solubilities for Aluminum and Sodium Nitrates in Nitric Acid 
Solubility data for many of the nitric acid-water-nitrate salt system were obtained at several temperatures. The data for these systems are plotted in Figs A-4 through A-8. Note that the remaining data have been plotted as wt\% of salt versus mol\% of salt-free nitric acid. Thus, comparisons can easily be made between the acid concentrations for solubility data and corresponding acid concentrations presented in Appendix B for the vapor-liquid equilibrium data. The mol\% nitric acid was calculated from the given solubility data. According to Yakimov [SILOCK-1979B], the discrepancy between the data at $49.1^{\circ} \mathrm{C}$ and $50^{\circ} \mathrm{C}$ above $60 \mathrm{~mol} \%$ nitric acid, as shown in Fig. A-8, is probably due to the presence of $\mathrm{NO}_{2}^{-}$in solution [SILOCK-1979J]. Yakimov suggested that the use of fuming nitric acid by Gaunt (data at $49.1^{\circ} \mathrm{C}$ ) allowed $\mathrm{UO}_{2}\left(\mathrm{NO}_{2}\right)_{2}$ solids to form. This compound's solubility is much lower than $\mathrm{UO}_{2}\left(\mathrm{NO}_{3}\right)_{2}$.

Since most of the waste streams to be concentrated will contain multiple salts in aqueous nitric acid, it would be helpful to know how the solubility of a salt changes with the presence of additional salts. Solubility data, however, were very limited for multiple salt systems in aqueous nitric acid. Multiple salt systems for which data are available include $\mathrm{NaNO}_{3}-\mathrm{KNO}_{3}, \mathrm{Ca}\left(\mathrm{NO}_{3}\right)_{2}-\mathrm{Sr}\left(\mathrm{NO}_{3}\right)_{2}$, $\mathrm{Fe}\left(\mathrm{NO}_{3}\right)_{3}-\mathrm{Th}\left(\mathrm{NO}_{3}\right)_{4}, \mathrm{UO}_{2}\left(\mathrm{NO}_{3}\right)_{2}-\mathrm{Mg}\left(\mathrm{NO}_{3}\right)_{2}, \mathrm{UO}_{2}\left(\mathrm{NO}_{3}\right)_{2}-\mathrm{Ca}\left(\mathrm{NO}_{3}\right)_{2}$, and $\mathrm{UO}_{2}\left(\mathrm{NO}_{3}\right)_{2}-\mathrm{Cu}\left(\mathrm{NO}_{3}\right)_{2}$. The data from the first two systems were not very useful since the concentration of both salts and the acid were varied for each data point. The other four systems maintained the nitric acid concentration at $1.5 \underline{\mathrm{M}}$ and only varied the salt concentrations. The data for the $\mathrm{UO}_{2}{ }^{2+}$ systems are plotted in Fig. A-9. The solution densities were also reported, allowing the conversion to molarity units.

From Fig. A-9, it is apparent that when two salts are present in solution, the solubility of both salts is lower than it would be for the single salt in solution. This effect is called the common-ion effect.

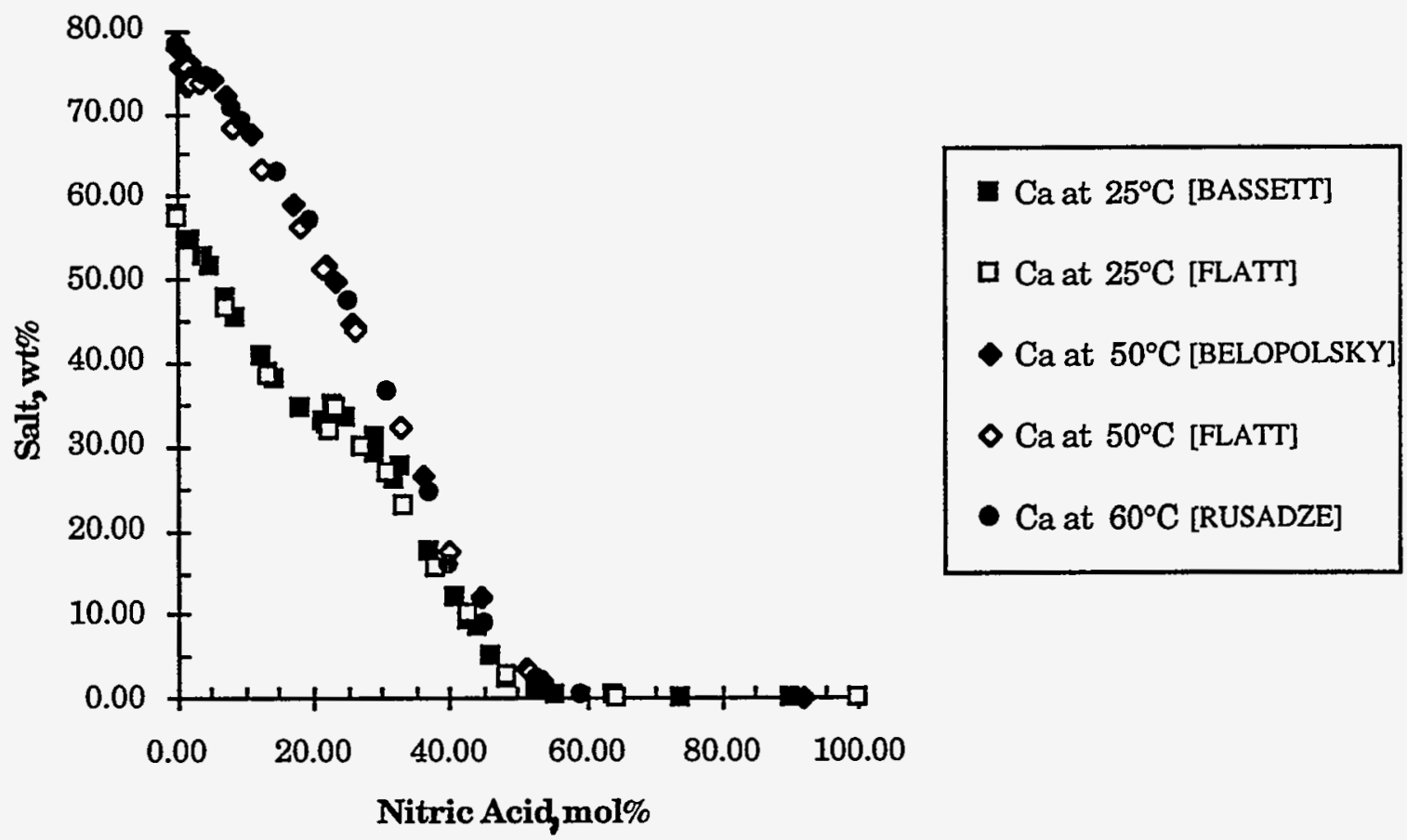

Fig. A-4. Solubility of $\mathrm{Ca}\left(\mathrm{NO}_{3}\right)_{2}$ in Nitric Acid at $25^{\circ} \mathrm{C}, 50^{\circ} \mathrm{C}$, and $60^{\circ} \mathrm{C}$ 


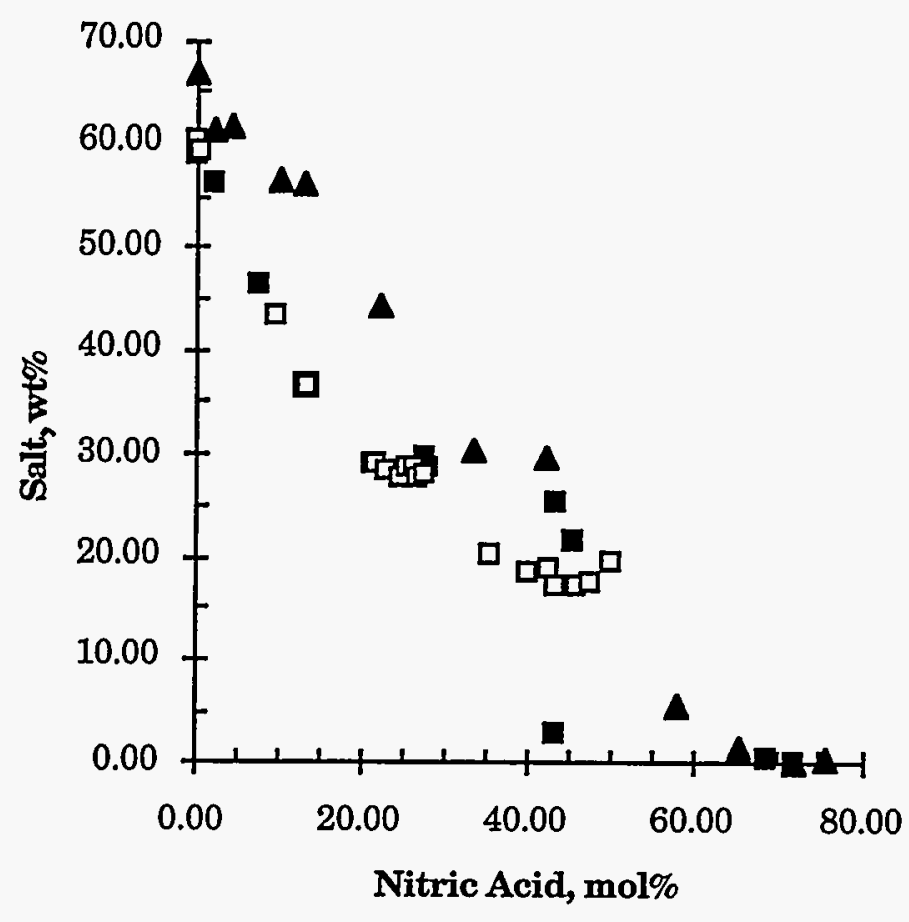

- La at $25^{\circ} \mathrm{C}$ [QUILL and ROBEY]

- La at $25^{\circ} \mathrm{C}$ [MIRONOV]

$\triangle \mathrm{La}$ at $50^{\circ} \mathrm{C}$ [QUILL and ROBEY]

Fig. A-5. Solubility of $\mathrm{La}\left(\mathrm{NO}_{3}\right)_{3}$ in Nitric Acid at $25^{\circ} \mathrm{C}$ and $50^{\circ} \mathrm{C}$

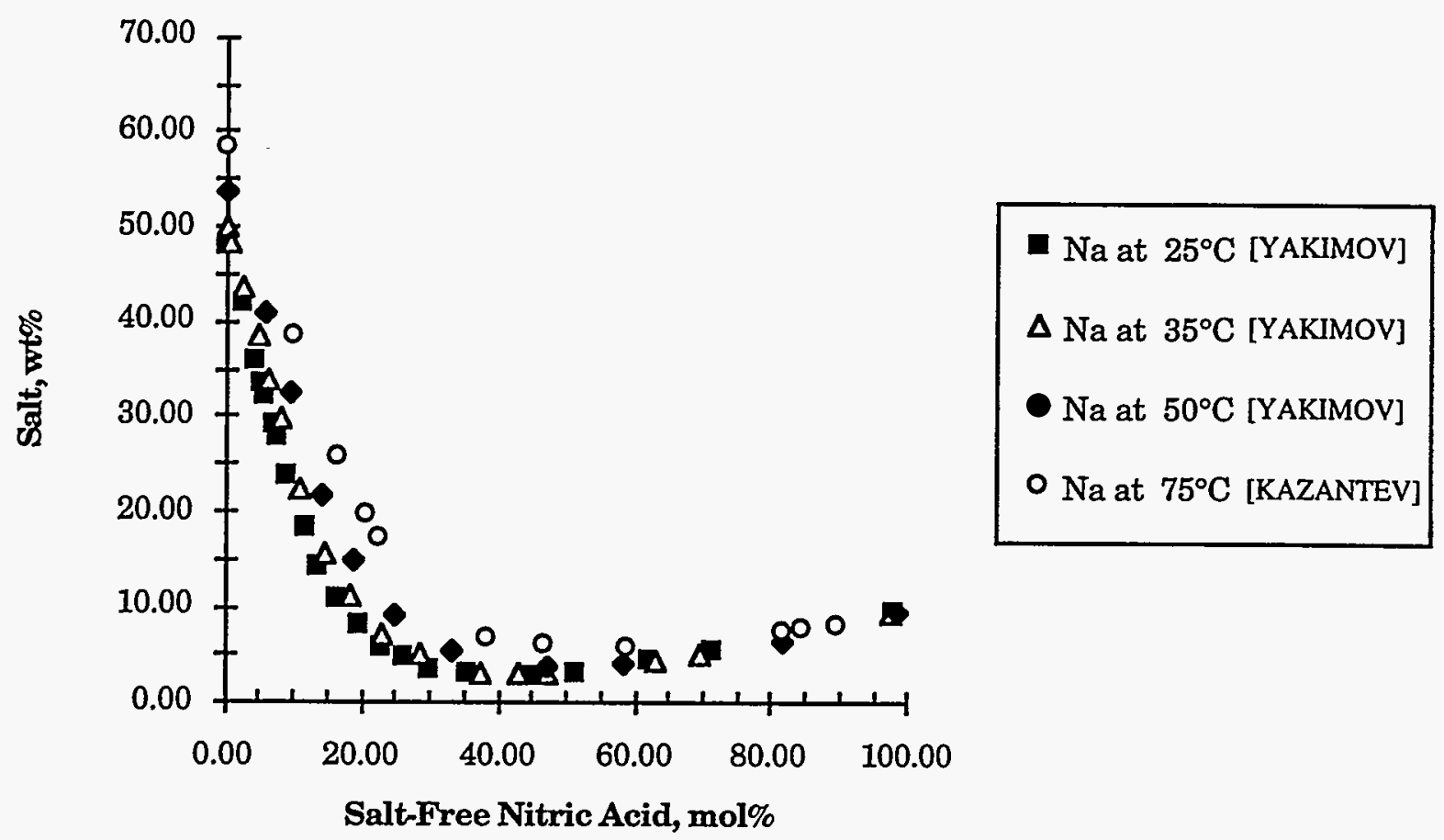

Fig A-6. Solubility of $\mathrm{NaNO}_{3}$ in Nitric Acid at $25^{\circ} \mathrm{C}, 35^{\circ} \mathrm{C}, 50^{\circ} \mathrm{C}$, and $75^{\circ} \mathrm{C}$ 


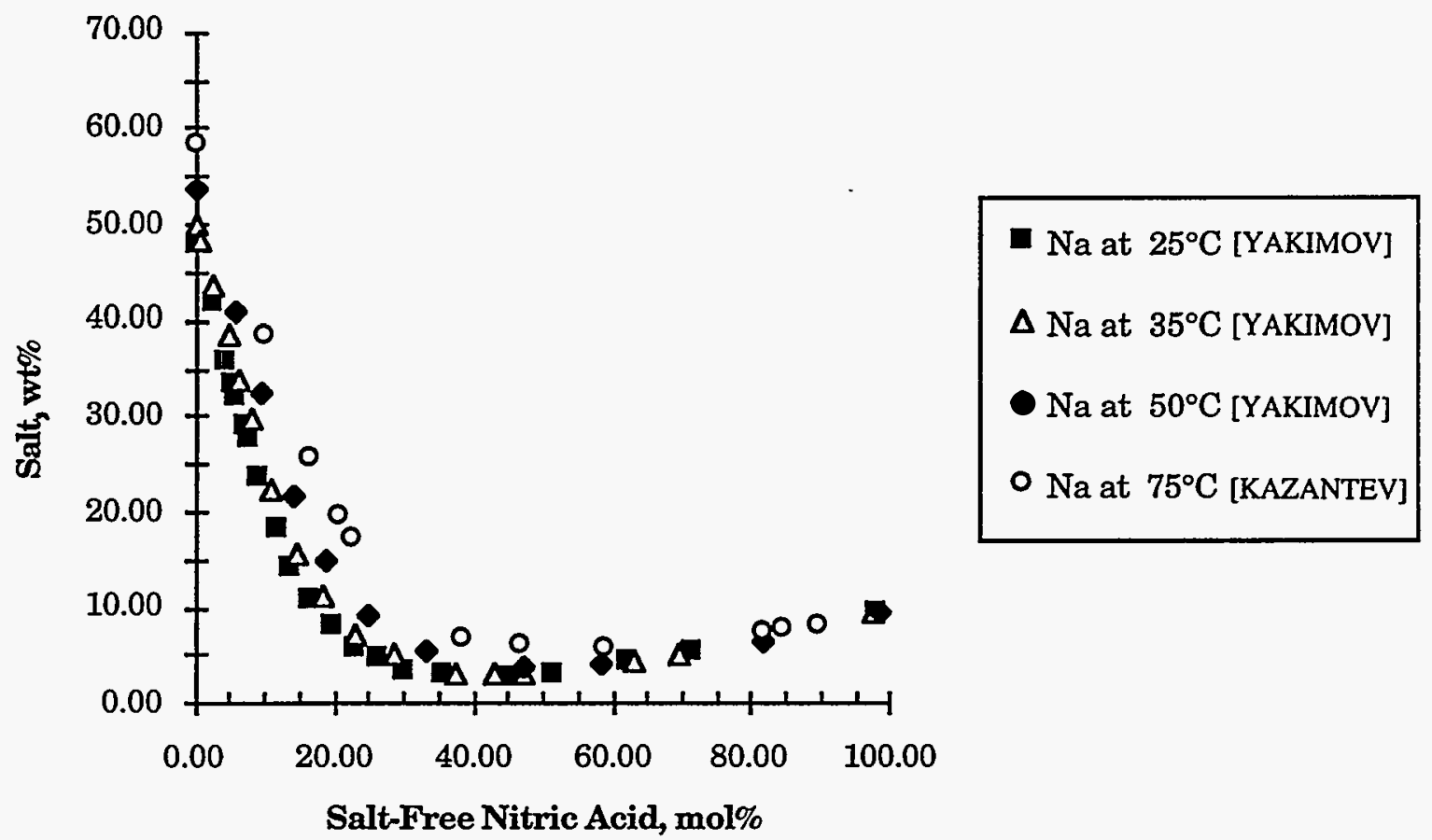

Fig. A-7. Solubility of $\operatorname{Sm}\left(\mathrm{NO}_{3}\right)_{3}$ in Nitric Acid at $25^{\circ} \mathrm{C}$ and $50^{\circ} \mathrm{C}$

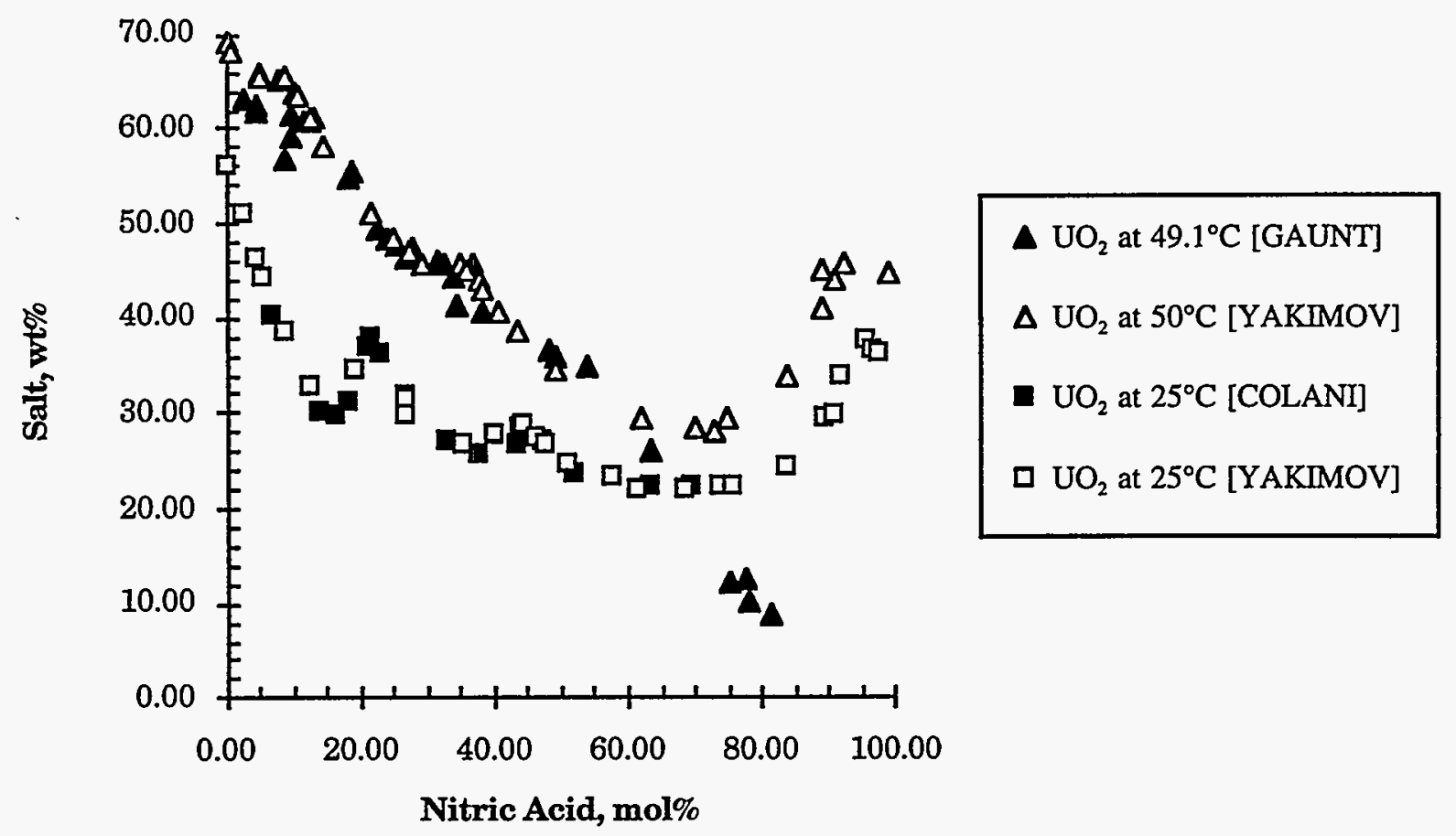

Fig. A-8. Solubility of $\mathrm{UO}_{2}\left(\mathrm{NO}_{3}\right)_{2}$ in Nitric Acid at $25^{\circ} \mathrm{C}, 49.1^{\circ} \mathrm{C}$, and $50^{\circ} \mathrm{C}$ 


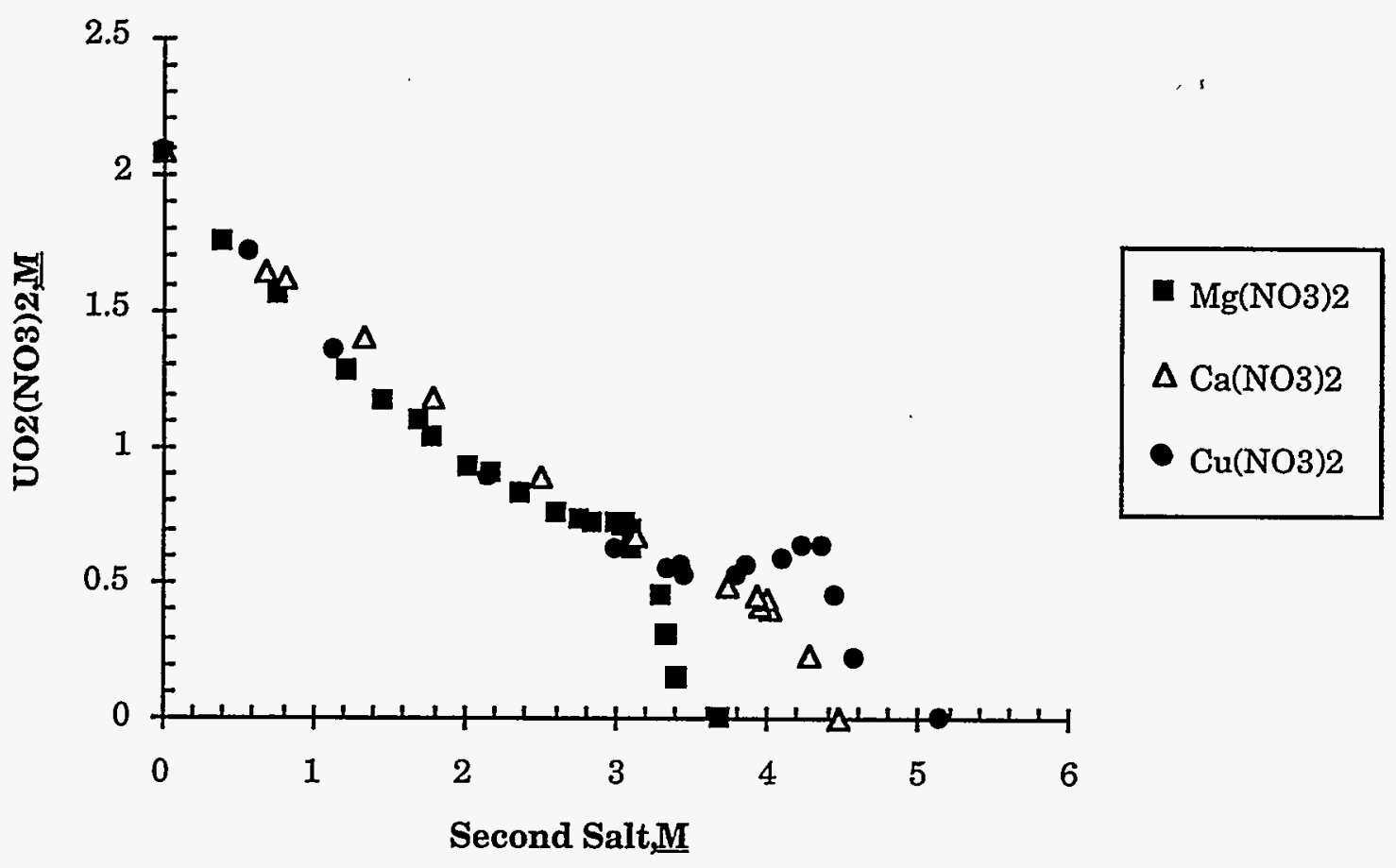

Fig. A-9. Solubility of $\mathrm{UO}_{2}\left(\mathrm{NO}_{3}\right)_{2}$ in the Presence of a Second Nitrate Salt in $1.5 \mathrm{M} \mathrm{HNO}_{3}$ at $25^{\circ} \mathrm{C}$

From the solubility data presented in this report, a few trends can be noted. First, solubility of a salt decreases with increasing nitric acid concentration. In some cases, such as sodium nitrate at very high acid concentrations, solubility begins to increase after reaching a minimum. Second, solubility increases with increasing temperature. This effect diminishes with increasing acid concentration. Third, the presence of more than one salt decreases the solubility of all salts compared to the single-salt solubility.

Table A-4. Solubility Data for $\mathrm{Al}\left(\mathrm{NO}_{3}\right)_{3}$ in Nitric Acid-Water at $25^{\circ} \mathrm{Ca}$

\begin{tabular}{cccccc}
\hline $\begin{array}{c}{\left[\mathrm{HNO}_{3}\right],} \\
\mathrm{wt} \%\end{array}$ & $\begin{array}{c}{\left[\mathrm{HNO}_{3}\right],} \\
\mathrm{mol} \%\end{array}$ & $\begin{array}{c}{\left[\mathrm{Al}\left(\mathrm{NO}_{3}\right)_{3}\right],} \\
\mathrm{wt} \%\end{array}$ & $\begin{array}{c}\text { Calculated } \\
\text { Density, } \\
\mathrm{g} / \mathrm{mL}\end{array}$ & $\begin{array}{c}{\left[\mathrm{HNO}_{3}\right],} \\
\mathrm{M}\end{array}$ & $\begin{array}{c}\left.\left[\mathrm{Al}^{2} \mathrm{NO}_{3}\right)_{3}\right], \\
\underline{\mathrm{M}}\end{array}$ \\
\hline 0.00 & 0.00 & 39.00 & 1.45 & 0.00 & 2.65 \\
10.00 & 4.58 & 30.50 & 1.42 & 2.25 & 2.03 \\
20.00 & 9.05 & 22.60 & 1.40 & 4.44 & 1.48 \\
30.00 & 13.59 & 15.50 & 1.39 & 6.63 & 1.01 \\
40.00 & 18.31 & 9.00 & 1.39 & 8.85 & 0.59 \\
50.00 & 23.66 & 3.90 & 1.42 & 11.27 & 0.26 \\
60.00 & 30.86 & 1.60 & 1.49 & 14.23 & 0.11 \\
65.10 & 35.50 & 1.10 & 1.55 & 15.99 & 0.08 \\
68.50 & 39.09 & 1.00 & 1.59 & 17.30 & 0.07 \\
72.50 & 44.06 & 1.20 & 1.65 & 19.00 & 0.09 \\
75.00 & 46.76 & 0.60 & 1.67 & 19.94 & 0.05 \\
80.00 & 53.58 & 0.20 & 1.74 & 22.14 & 0.02 \\
85.00 & 61.98 & 0.10 & 1.83 & 24.64 & 0.01 \\
90.00 & 72.71 & 0.35 & 1.93 & 27.53 & 0.03 \\
\hline
\end{tabular}

a[LINKE-1958A] 
Table A-5. Solubility Data for $\mathrm{Ca}\left(\mathrm{NO}_{3}\right)_{2}$ in Nitric Acid-Water at $25^{\circ} \mathrm{Ca}$

\begin{tabular}{cccccc}
\hline $\begin{array}{c}{\left[\mathrm{HNO}_{3}\right],} \\
\text { wt\% }\end{array}$ & $\begin{array}{c}{\left[\mathrm{HNO}_{3}\right],} \\
\mathrm{mol} \%\end{array}$ & $\begin{array}{c}{\left[\mathrm{Ca}\left(\mathrm{NO}_{3}\right)_{2}\right],} \\
\text { wt\% }\end{array}$ & $\begin{array}{c}\text { Calculated } \\
\text { Density, } \\
\mathrm{g} / \mathrm{mL}\end{array}$ & $\begin{array}{c}{\left[\mathrm{HNO}_{3}\right],} \\
\mathrm{M}\end{array}$ & $\begin{array}{c}{\left[\mathrm{Ca}\left(\mathrm{NO}_{3}\right)_{2}\right],} \\
\mathrm{M}\end{array}$ \\
\hline 0.00 & 0.00 & 57.98 & 1.76 & 0.00 & 6.23 \\
3.33 & 2.22 & 54.82 & 1.75 & 0.92 & 5.83 \\
5.87 & 3.91 & 52.96 & 1.74 & 1.63 & 5.63 \\
7.21 & 4.76 & 51.58 & 1.73 & 1.98 & 5.45 \\
11.27 & 7.30 & 47.82 & 1.71 & 3.07 & 5.00 \\
13.71 & 8.78 & 45.59 & 1.70 & 3.71 & 4.73 \\
19.65 & 12.40 & 40.70 & 1.69 & 5.27 & 4.19 \\
22.80 & 14.30 & 38.17 & 1.68 & 6.09 & 3.92 \\
28.81 & 18.31 & 34.46 & 1.70 & 7.75 & 3.56 \\
32.63 & 21.26 & 32.84 & 1.72 & 8.91 & 3.44 \\
33.52 & 21.99 & 32.50 & 1.73 & 9.18 & 3.42 \\
35.63 & 24.76 & 33.44 & 1.78 & 10.08 & 3.63 \\
41.66 & 28.90 & 29.05 & 1.78 & 11.77 & 3.15 \\
45.70 & 32.93 & 27.70 & 1.82 & 13.18 & 3.07 \\
40.56 & 29.02 & 31.09 & 1.81 & 11.66 & 3.43 \\
45.70 & 31.63 & 26.07 & 1.78 & 12.89 & 2.82 \\
55.48 & 36.90 & 17.41 & 1.74 & 15.30 & 1.84 \\
62.05 & 40.82 & 12.25 & 1.73 & 17.01 & 1.29 \\
65.69 & 42.91 & 9.34 & 1.72 & 17.93 & 0.98 \\
67.20 & 44.16 & 8.52 & 1.73 & 18.40 & 0.90 \\
71.12 & 46.04 & 5.06 & 1.71 & 19.31 & 0.53 \\
74.77 & 48.48 & 2.53 & 1.71 & 20.32 & 0.26 \\
78.56 & 52.40 & 1.05 & 1.74 & 21.69 & 0.11 \\
80.83 & 55.35 & 0.54 & 1.76 & 22.64 & 0.06 \\
85.83 & 63.97 & 0.36 & 1.85 & 25.17 & 0.04 \\
90.90 & 74.07 & 0.01 & 1.93 & 27.92 & 0.00 \\
96.86 & 89.81 & 0.00 & 2.06 & 31.70 & 0.00 \\
\hline
\end{tabular}

a[LINKE-1958B]

Table A-6. Solubility Data for $\mathrm{Fe}\left(\mathrm{NO}_{3}\right)_{3}$ in Nitric Acid-Water at $25^{\circ} \mathrm{C}^{\mathrm{a}}$

\begin{tabular}{cccccc}
\hline $\begin{array}{c}{\left[\mathrm{HNO}_{3}\right],} \\
\text { wt\% }\end{array}$ & $\begin{array}{c}{\left[\mathrm{HNO}_{3}\right],} \\
\mathrm{mol \%}\end{array}$ & $\begin{array}{c}{\left[\mathrm{Fe}\left(\mathrm{NO}_{3}\right)_{3}\right],} \\
\mathrm{wt} \%\end{array}$ & $\begin{array}{c}\text { Calculated } \\
\text { Density, } \\
\mathrm{g} / \mathrm{mL}\end{array}$ & $\begin{array}{c}{\left[\mathrm{HNO}_{3}\right],} \\
\mathrm{M}\end{array}$ & $\begin{array}{c}{\left[\mathrm{Fe}\left(\mathrm{NO}_{3}\right)_{3}\right],} \\
\underline{\mathrm{M}}\end{array}$ \\
\hline 53.48 & 35.01 & 18.15 & 1.76 & 14.93 & 1.32 \\
53.79 & 39.24 & 22.41 & 1.88 & 16.05 & 1.74 \\
54.23 & 46.61 & 28.02 & 2.07 & 17.79 & 2.39 \\
57.03 & 52.30 & 28.11 & 2.14 & 19.34 & 2.48 \\
\hline
\end{tabular}

a[SILOCK-1979A] 
Table A-7. Solubility Data for $\mathrm{La}\left(\mathrm{NO}_{3}\right)_{3}$ in Nitric Acid-Water at $25^{\circ} \mathrm{C}^{\mathrm{a}}$

\begin{tabular}{cccccc}
\hline $\begin{array}{c}{\left[\mathrm{HNO}_{3}\right],} \\
\text { wt\% }\end{array}$ & $\begin{array}{c}{\left[\mathrm{HNO}_{3}\right],} \\
\mathrm{mol} \%\end{array}$ & $\begin{array}{c}{\left[\mathrm{La}\left(\mathrm{NO}_{3}\right)_{3}\right],} \\
\text { wt\% }\end{array}$ & $\begin{array}{c}\text { Calculated } \\
\text { Density, } \\
\mathrm{g} / \mathrm{mL}\end{array}$ & $\begin{array}{c}{\left[\mathrm{HNO}_{3}\right],} \\
\mathrm{M}\end{array}$ & $\begin{array}{c}{\left[\mathrm{La}\left(\mathrm{NO}_{3}\right)_{3}\right],} \\
\mathrm{M}\end{array}$ \\
\hline 0.00 & 0.00 & 60.27 & 2.04 & 0.00 & 3.78 \\
0.80 & 0.57 & 59.30 & 2.02 & 0.26 & 3.69 \\
15.50 & 9.71 & 43.30 & 1.81 & 4.46 & 2.42 \\
22.40 & 13.45 & 36.40 & 1.74 & 6.20 & 1.95 \\
35.10 & 21.88 & 29.10 & 1.76 & 9.81 & 1.58 \\
36.80 & 23.10 & 28.20 & 1.77 & 10.32 & 1.53 \\
38.50 & 24.55 & 27.70 & 1.78 & 10.89 & 1.52 \\
38.80 & 25.49 & 28.80 & 1.82 & 11.19 & 1.61 \\
39.60 & 26.36 & 28.80 & 1.83 & 11.51 & 1.62 \\
40.50 & 26.74 & 27.80 & 1.82 & 11.69 & 1.56 \\
41.10 & 27.60 & 28.10 & 1.84 & 11.99 & 1.59 \\
52.50 & 35.55 & 20.30 & 1.82 & 15.17 & 1.14 \\
57.00 & 40.03 & 18.60 & 1.85 & 16.76 & 1.06 \\
58.40 & 42.36 & 18.90 & 1.89 & 17.49 & 1.10 \\
60.20 & 43.11 & 17.10 & 1.87 & 17.84 & 0.98 \\
62.10 & 45.91 & 17.00 & 1.90 & 18.73 & 0.99 \\
62.90 & 47.58 & 17.30 & 1.93 & 19.22 & 1.03 \\
62.50 & 49.80 & 19.50 & 1.99 & 19.73 & 1.19 \\
\hline a[SIEKIERSKI-1966A] & & & & \\
\hline
\end{tabular}

Table A-8. Solubility Data for $\mathrm{NaNO}_{3}$ in Nitric Acid-Water at $25^{\circ} \mathrm{C}^{\mathrm{a}}$

\begin{tabular}{cccccc}
\hline $\begin{array}{c}{\left[\mathrm{HNO}_{3}\right],} \\
w t \%\end{array}$ & $\begin{array}{c}{\left[\mathrm{HNO}_{3}\right],} \\
\mathrm{mol} \%\end{array}$ & $\begin{array}{c}{\left[\mathrm{NaNO}_{3}\right],} \\
\mathrm{wt} \%\end{array}$ & $\begin{array}{c}\text { Calculated } \\
\text { Density, } \\
\mathrm{g} / \mathrm{mL}\end{array}$ & $\begin{array}{c}{\left[\mathrm{HNO}_{3}\right],} \\
\mathrm{M}\end{array}$ & $\begin{array}{c}{\left[\mathrm{NaNO}_{3}\right],} \\
\underline{\mathrm{M}}\end{array}$ \\
\hline 0.00 & 0.00 & 47.90 & 1.47 & 0.00 & 8.26 \\
4.30 & 2.24 & 42.10 & 1.43 & 0.98 & 7.10 \\
9.20 & 4.56 & 35.80 & 1.40 & 2.05 & 5.90 \\
10.80 & 5.26 & 33.60 & 1.39 & 2.38 & 5.49 \\
11.90 & 5.73 & 32.20 & 1.38 & 2.61 & 5.24 \\
14.90 & 7.06 & 29.10 & 1.37 & 3.25 & 4.70 \\
16.10 & 7.55 & 27.60 & 1.37 & 3.49 & 4.44 \\
19.90 & 9.14 & 23.60 & 1.35 & 4.28 & 3.76 \\
25.70 & 11.59 & 18.30 & 1.35 & 5.49 & 2.90 \\
30.90 & 13.88 & 14.30 & 1.35 & 6.61 & 2.27 \\
36.40 & 16.48 & 10.90 & 1.36 & 7.86 & 1.74 \\
42.20 & 19.52 & 8.10 & 1.38 & 9.26 & 1.32 \\
47.90 & 22.89 & 6.00 & 1.42 & 10.76 & 1.00 \\
52.70 & 26.16 & 4.80 & 1.45 & 12.14 & 0.82 \\
57.80 & 29.96 & 3.60 & 1.49 & 13.70 & 0.63 \\
63.87 & 35.52 & 3.00 & 1.56 & 15.81 & 0.55 \\
71.90 & 44.71 & 2.70 & 1.67 & 19.01 & 0.53 \\
76.20 & 51.26 & 3.10 & 1.74 & 21.04 & 0.63 \\
81.40 & 62.26 & 4.50 & 1.86 & 24.04 & 0.98 \\
84.90 & 71.43 & 5.40 & 1.95 & 26.28 & 1.24 \\
90.00 & 98.09 & 9.50 & 2.18 & 31.19 & 244 \\
\hline
\end{tabular}

a[YAKIMOV] 
Table A-9. Solubility Data for $\mathrm{Ni}\left(\mathrm{NO}_{3}\right)_{2}$ in Nitric Acid-Water at $25^{\circ} \mathrm{C}^{\mathrm{a}}$

\begin{tabular}{|c|c|c|c|c|c|}
\hline $\begin{array}{c}{\left[\mathrm{HNO}_{3}\right]} \\
\mathrm{wt} \%\end{array}$ & $\begin{array}{c}{\left[\mathrm{HNO}_{3}\right]} \\
\text { mol\% }\end{array}$ & $\begin{array}{c}{\left[\mathrm{Ni}\left(\mathrm{NO}_{3}\right)_{2}\right]} \\
\mathrm{wt} \%\end{array}$ & $\begin{array}{l}\text { Calculated } \\
\text { Density, } \\
\text { g/mL }\end{array}$ & $\begin{array}{c}{\left[\mathrm{HNO}_{3}\right],} \\
\underline{\mathrm{M}}\end{array}$ & $\begin{array}{c}{\left[\mathrm{Ni}\left(\mathrm{NO}_{3}\right)_{2}\right],} \\
\underline{\mathrm{M}}\end{array}$ \\
\hline 7.60 & 4.25 & 43.50 & 1.68 & 2.02 & 3.99 \\
\hline 13.20 & 7.30 & 38.90 & 1.65 & 3.46 & 3.52 \\
\hline 19.10 & 10.48 & 34.30 & 1.63 & 4.95 & 3.07 \\
\hline 24.10 & 13.09 & 30.20 & 1.61 & 6.17 & 2.67 \\
\hline 32.10 & 17.51 & 24.70 & 1.60 & 8.17 & 2.17 \\
\hline 40.00 & 22.27 & 20.10 & 1.61 & 10.24 & 1.77 \\
\hline 52.00 & 31.71 & 16.00 & 1.69 & 13.98 & 1.48 \\
\hline 60.20 & 36.52 & 9.90 & 1.67 & 15.99 & 0.91 \\
\hline 65.20 & 40.47 & 7.40 & 1.69 & 17.48 & 0.68 \\
\hline 70.50 & 46.05 & 5.90 & 1.74 & 19.42 & 0.56 \\
\hline 73.90 & 50.37 & 5.30 & 1.78 & 20.83 & 0.52 \\
\hline 78.60 & 58.09 & 5.20 & 1.86 & 23.15 & 0.53 \\
\hline 80.50 & 61.33 & 5.00 & 1.89 & 24.09 & 0.52 \\
\hline 81.60 & 61.98 & 4.10 & 1.88 & 24.34 & 0.42 \\
\hline 84.30 & 64.95 & 2.70 & 1.89 & 25.27 & 0.28 \\
\hline 89.80 & 74.25 & 1.30 & 1.95 & 27.85 & 0.14 \\
\hline 95.30 & 86.09 & 0.30 & 2.04 & 30.82 & 0.03 \\
\hline 99.50 & 98.44 & 0.05 & 2.13 & 33.57 & 0.01 \\
\hline
\end{tabular}

a[LINKE-1965A] 
Table A-10. Solubility Data for $\mathrm{Sm}\left(\mathrm{NO}_{3}\right)_{3}$ in Nitric Acid-Water at $25^{\circ} \mathrm{Ca}$

\begin{tabular}{|c|c|c|c|c|c|}
\hline $\begin{array}{c}{\left[\mathrm{HNO}_{3}\right],} \\
\mathrm{wt} \%\end{array}$ & $\begin{array}{c}{\left[\mathrm{HNO}_{3}\right]} \\
\mathrm{mol} \%\end{array}$ & $\begin{array}{c}{\left[\mathrm{Sm}\left(\mathrm{NO}_{3}\right)_{3}\right]} \\
\mathrm{wt} \%\end{array}$ & $\begin{array}{l}\text { Calculated } \\
\text { Density, } \\
\text { g/mL }\end{array}$ & $\begin{array}{c}{\left[\mathrm{HNO}_{3}\right],} \\
\underline{\mathrm{M}}\end{array}$ & $\begin{array}{c}{\left[\mathrm{Sm}\left(\mathrm{NO}_{3}\right)_{3}\right]} \\
\underline{\mathrm{M}}\end{array}$ \\
\hline 0.00 & 0.00 & 61.14 & 2.11 & 0.00 & 3.84 \\
\hline 3.40 & 2.43 & 57.60 & 2.06 & 1.11 & 3.52 \\
\hline 8.90 & 6.09 & 51.90 & 1.98 & 2.79 & 3.05 \\
\hline 15.80 & 10.01 & 43.60 & 1.85 & 4.64 & 2.40 \\
\hline 38.80 & 21.87 & 21.60 & 1.64 & 10.12 & 1.06 \\
\hline 40.70 & 22.97 & 20.30 & 1.64 & 10.60 & 0.99 \\
\hline 46.60 & 26.73 & 16.90 & 1.65 & 12.18 & 0.83 \\
\hline 51.50 & 30.21 & 14.50 & 1.66 & 13.58 & 0.72 \\
\hline 52.10 & 30.83 & 14.50 & 1.67 & 13.81 & 0.72 \\
\hline 52.20 & 30.93 & 14.50 & 1.67 & 13.85 & 0.72 \\
\hline 52.50 & 31.32 & 14.60 & 1.68 & 13.99 & 0.73 \\
\hline 56.60 & 34.43 & 12.60 & 1.69 & 15.20 & 0.63 \\
\hline 59.20 & 36.44 & 11.30 & 1.70 & 15.97 & 0.57 \\
\hline 62.30 & 39.47 & 10.40 & 1.72 & 17.06 & 0.53 \\
\hline 64.10 & 41.70 & 10.30 & 1.75 & 17.82 & 0.54 \\
\hline 66.90 & 45.71 & 10.40 & 1.80 & 19.13 & 0.56 \\
\hline 67.00 & 50.06 & 13.90 & 1.91 & 20.28 & 0.79 \\
\hline 66.00 & 49.16 & 14.50 & 1.91 & 19.97 & 0.82 \\
\hline 66.00 & 50.61 & 15.60 & 1.94 & 20.34 & 0.90 \\
\hline 66.30 & 51.00 & 15.50 & 1.94 & 20.46 & 0.90 \\
\hline 65.00 & 51.49 & 17.50 & 1.98 & 20.48 & 1.03 \\
\hline 66.70 & 52.13 & 15.80 & 1.96 & 20.78 & 0.92 \\
\hline 68.10 & 52.79 & 14.50 & 1.95 & 21.06 & 0.84 \\
\hline 68.50 & 56.61 & 16.50 & 2.02 & 22.02 & 0.99 \\
\hline 69.70 & 59.78 & 16.90 & 2.07 & 22.86 & 1.04 \\
\hline 69.70 & 62.40 & 18.30 & 2.12 & 23.45 & 1.15 \\
\hline 70.00 & 65.57 & 19.50 & 2.17 & 24.16 & 1.26 \\
\hline 71.00 & 65.89 & 18.50 & 2.16 & 24.33 & 1.19 \\
\hline 73.90 & 70.11 & 17.10 & 2.17 & 25.51 & 1.11 \\
\hline 78.50 & 72.99 & 13.20 & 2.13 & 26.57 & 0.84 \\
\hline 80.10 & 72.92 & 11.40 & 2.10 & 26.71 & 0.71 \\
\hline 84.70 & 75.63 & 7.50 & 2.06 & 27.71 & 0.46 \\
\hline 88.70 & 81.12 & 5.40 & 2.08 & 29.21 & 0.33 \\
\hline 90.30 & 81.39 & 3.80 & 2.05 & 29.42 & 0.23 \\
\hline 94.20 & 91.19 & 3.20 & 2.12 & 31.71 & 0.20 \\
\hline 95.60 & 91.92 & 2.00 & 2.11 & 31.98 & 0.13 \\
\hline 98.30 & 99.65 & 1.60 & 2.16 & 33.66 & 0.10 \\
\hline
\end{tabular}

a[SIEKIERSKI-1966B] 
Table A-11. Solubility Data for $\mathrm{UO}_{2}\left(\mathrm{NO}_{3}\right)_{2}$ in Nitric Acid-Water at $25^{\circ} \mathrm{Ca}$

\begin{tabular}{cccccc}
\hline $\begin{array}{c}{\left[\mathrm{HNO}_{3}\right],} \\
\text { wt\% }\end{array}$ & $\begin{array}{c}{\left[\mathrm{HNO}_{3}\right],} \\
\mathrm{mol} \%\end{array}$ & $\begin{array}{c}{\left[\mathrm{UO}_{2}\left(\mathrm{NO}_{3}\right)_{2}\right],} \\
\mathrm{wt} \%\end{array}$ & $\begin{array}{c}\text { Calculated } \\
\text { Density, } \\
\mathrm{g} / \mathrm{mL}\end{array}$ & $\begin{array}{c}{\left[\mathrm{HNO}_{3}\right],} \\
\mathrm{M}\end{array}$ & $\begin{array}{c}\left.\mathrm{UO}_{2}\left(\mathrm{NO}_{3}\right)_{2}\right], \\
\mathrm{M}\end{array}$ \\
\hline 0.00 & 0.00 & 55.95 & 1.82 & 0.00 & 2.59 \\
3.80 & 2.34 & 50.90 & 1.76 & 1.06 & 2.27 \\
7.20 & 4.25 & 46.40 & 1.70 & 1.95 & 2.01 \\
9.10 & 5.30 & 44.40 & 1.69 & 2.43 & 1.90 \\
15.20 & 8.56 & 38.40 & 1.64 & 3.96 & 1.60 \\
22.40 & 12.50 & 32.80 & 1.62 & 5.77 & 1.35 \\
29.90 & 19.31 & 34.40 & 1.77 & 8.42 & 1.55 \\
38.40 & 26.98 & 31.90 & 1.86 & 11.32 & 1.50 \\
38.40 & 26.71 & 31.50 & 1.85 & 11.25 & 1.48 \\
39.60 & 26.93 & 29.70 & 1.82 & 11.43 & 1.37 \\
48.00 & 35.15 & 26.70 & 1.89 & 14.40 & 1.28 \\
50.70 & 40.03 & 27.60 & 1.97 & 15.86 & 1.38 \\
52.30 & 43.64 & 28.40 & 2.03 & 16.86 & 1.46 \\
52.50 & 44.38 & 28.70 & 2.05 & 17.04 & 1.49 \\
54.50 & 46.11 & 27.30 & 2.04 & 17.67 & 1.41 \\
55.70 & 47.49 & 26.70 & 2.05 & 18.11 & 1.39 \\
59.10 & 51.19 & 24.80 & 2.06 & 19.33 & 1.30 \\
63.40 & 57.66 & 23.30 & 2.11 & 21.21 & 1.25 \\
66.00 & 61.31 & 22.10 & 2.13 & 22.27 & 1.19 \\
68.90 & 68.39 & 22.00 & 2.19 & 24.00 & 1.23 \\
70.50 & 73.94 & 22.40 & 2.25 & 25.21 & 1.28 \\
71.10 & 75.48 & 22.30 & 2.26 & 25.56 & 1.28 \\
71.60 & 83.64 & 24.40 & 2.37 & 26.95 & 1.47 \\
68.20 & 89.44 & 29.50 & 2.51 & 27.17 & 1.88 \\
68.20 & 91.12 & 29.90 & 2.53 & 27.39 & 1.92 \\
64.70 & 92.03 & 33.70 & 2.61 & 26.81 & 2.23 \\
61.60 & 95.65 & 37.60 & 2.72 & 26.57 & 2.59 \\
62.70 & 96.76 & 36.70 & 2.71 & 26.94 & 2.52 \\
63.40 & 97.31 & 36.10 & 2.70 & 27.16 & 2.47 \\
\hline
\end{tabular}

a[SILOCK-1979B]

Table A-12. Solubility Data for $\mathrm{Al}\left(\mathrm{NO}_{3}\right)_{3}$ in Nitric Acid-Water at $20^{\circ} \mathrm{C}^{\mathrm{a}}$

\begin{tabular}{ccccc}
\hline $\begin{array}{c}{\left[\mathrm{HNO}_{3}\right],} \\
\mathrm{wt} \%\end{array}$ & $\begin{array}{c}{\left[\mathrm{Al}\left(\mathrm{NO}_{3}\right)_{3}\right],} \\
\mathrm{wt} \%\end{array}$ & $\begin{array}{c}\text { Density, } \\
\mathrm{g} / \mathrm{mL}\end{array}$ & $\begin{array}{c}{\left[\mathrm{HNO}_{3}\right],} \\
\underline{\mathrm{M}}\end{array}$ & $\begin{array}{c}{\left[\mathrm{Al}\left(\mathrm{NO}_{3}\right)_{3}\right],} \\
\mathrm{M}\end{array}$ \\
\hline 0 & 40.00 & 1.383 & 0.000 & 2.597 \\
10 & 31.00 & 1.368 & 2.171 & 1.991 \\
20 & 23.00 & 1.354 & 4.298 & 1.462 \\
30 & 16.00 & 1.345 & 6.405 & 1.010 \\
40 & 9.00 & 1.34 & 8.508 & 0.566 \\
50 & 4.00 & 1.345 & 10.675 & 0.253 \\
60 & 1.50 & 1.364 & 12.990 & 0.096 \\
70 & 0.75 & 1.405 & 15.611 & 0.049 \\
\hline
\end{tabular}

a[LINKE-1958C] 
Table A-13. Solubility Data for $\mathrm{Al}\left(\mathrm{NO}_{3}\right)_{3}$ in Nitric Acid-Water at $40^{\circ} \mathrm{C} a$

\begin{tabular}{ccccc}
\hline $\begin{array}{c}{\left[\mathrm{HNO}_{3}\right],} \\
\mathrm{wt} \%\end{array}$ & $\begin{array}{c}{\left[\mathrm{Al}\left(\mathrm{NO}_{3}\right)_{3}\right],} \\
\mathrm{wt} \%\end{array}$ & $\begin{array}{c}\text { Density, } \\
\mathrm{g} / \mathrm{mL}\end{array}$ & $\begin{array}{c}{\left[\mathrm{HNO}_{3}\right],} \\
\underline{\mathrm{M}}\end{array}$ & $\begin{array}{c}{\left[\mathrm{Al}\left(\mathrm{NO}_{3}\right)_{3}\right],} \\
\underline{\mathrm{M}}\end{array}$ \\
\hline 0.00 & 44.00 & 1.430 & 0.000 & 2.954 \\
10.00 & 36.00 & 1.402 & 2.225 & 2.370 \\
20.00 & 29.00 & 1.386 & 4.400 & 1.887 \\
30.00 & 21.00 & 1.377 & 6.557 & 1.358 \\
40.00 & 15.00 & 1.370 & 8.698 & 0.965 \\
50.00 & 9.50 & 1.375 & 10.913 & 0.613 \\
60.00 & 5.50 & 1.392 & 13.257 & 0.359 \\
70.00 & 3.00 & 1.430 & 15.889 & 0.201 \\
\hline
\end{tabular}

a[LINKE-1958C]

Table A-14. Solubility Data for $\mathrm{Al}\left(\mathrm{NO}_{3}\right)_{3}$ in Nitric Acid-Water at $60^{\circ} \mathrm{C}^{\mathrm{a}}$

\begin{tabular}{ccccc}
\hline $\begin{array}{c}{\left[\mathrm{HNO}_{3}\right],} \\
\text { wt\% }\end{array}$ & $\begin{array}{c}{\left[\mathrm{Al}\left(\mathrm{NO}_{3}\right)_{3}\right],} \\
w t \%\end{array}$ & $\begin{array}{c}\text { Density, } \\
\text { g/mL }\end{array}$ & $\begin{array}{c}{\left[\mathrm{HNO}_{3}\right],} \\
\underline{\mathrm{M}}\end{array}$ & $\begin{array}{c}{\left[\mathrm{Al}\left(\mathrm{NO}_{3}\right)_{3}\right],} \\
\underline{\mathrm{M}}\end{array}$ \\
\hline 0.00 & 47.50 & 1.461 & 0.000 & 3.258 \\
10.00 & 40.50 & 1.457 & 2.313 & 2.770 \\
20.00 & 34.50 & 1.457 & 4.625 & 2.360 \\
30.00 & 29.00 & 1.460 & 6.952 & 1.988 \\
40.00 & 24.00 & 1.468 & 9.321 & 1.654 \\
50.00 & 20.00 & 1.480 & 11.746 & 1.390 \\
\hline
\end{tabular}

a[LINKE-1958C]

Table A-15. Solubility Data for $\mathrm{NaNO}_{3}-\mathrm{KNO}_{3}$ in Nitric Acid-Water at $25^{\circ} \mathrm{C}^{\mathrm{a}}$

\begin{tabular}{cccc}
\hline $\begin{array}{c}{\left[\mathrm{HNO}_{3}\right],} \\
\mathrm{wt} \%\end{array}$ & $\begin{array}{c}{\left[\mathrm{HNO}_{3}\right],} \\
\mathrm{mol} \%\end{array}$ & $\begin{array}{c}{\left[\mathrm{NaNO}_{3}\right],} \\
\mathrm{wt} \%\end{array}$ & $\begin{array}{c}{\left[\mathrm{KNO}_{3}\right],} \\
\mathrm{wt} \%\end{array}$ \\
\hline 0.00 & 0.00 & 40.26 & 19.17 \\
5.20 & 3.43 & 35.26 & 17.68 \\
10.66 & 6.57 & 30.01 & 16.04 \\
16.17 & 9.42 & 23.64 & 15.74 \\
21.18 & 12.21 & 19.24 & 16.06 \\
32.65 & 19.12 & 11.20 & 16.70 \\
38.98 & 23.07 & 7.15 & 16.74 \\
42.61 & 23.35 & 5.75 & 11.68 \\
54.04 & 30.41 & 4.10 & 6.52 \\
58.62 & 32.95 & 3.82 & 3.48 \\
62.59 & 35.10 & 3.32 & 1.02 \\
\hline
\end{tabular}

a[SILOCK-1979C] 
Table A-16. Solubility Data for $\mathrm{Ca}\left(\mathrm{NO}_{3}\right)_{2}-\mathrm{Sr}\left(\mathrm{NO}_{3}\right)_{2}$ in Nitric Acid-Water at $25^{\circ} \mathrm{C}^{\mathrm{a}}$

\begin{tabular}{ccccc}
\hline $\begin{array}{c}{\left[\mathrm{HNO}_{3}\right],} \\
\text { wt\% }\end{array}$ & $\begin{array}{c}{\left[\mathrm{HNO}_{3}\right],} \\
\mathrm{mol} \%\end{array}$ & $\begin{array}{c}{\left[\mathrm{Ca}\left(\mathrm{NO}_{3}\right)_{2}\right],} \\
\text { wt\% }\end{array}$ & $\begin{array}{c}{\left[\mathrm{Sr}\left(\mathrm{NO}_{3}\right)_{2}\right],} \\
\text { wt\% }\end{array}$ & $\begin{array}{c}{\left[\mathrm{H}_{2} \mathrm{O}\right],} \\
\text { wt\% }\end{array}$ \\
\hline 10.05 & 4.51 & 0.00 & 29.20 & 60.75 \\
9.76 & 4.39 & 0.95 & 28.55 & 60.74 \\
9.89 & 4.45 & 1.49 & 27.92 & 60.70 \\
9.57 & 4.35 & 7.66 & 22.65 & 60.12 \\
9.88 & 4.59 & 15.53 & 15.92 & 58.67 \\
9.98 & 4.77 & 22.11 & 10.94 & 56.97 \\
10.03 & 5.25 & 33.98 & 4.26 & 51.73 \\
10.35 & 6.62 & 47.47 & 0.48 & 41.70 \\
9.91 & 6.42 & 48.41 & 0.41 & 41.27 \\
10.19 & 6.63 & 48.84 & 0.00 & 40.97 \\
20.13 & 8.22 & 0.00 & 15.62 & 64.25 \\
19.74 & 8.15 & 3.87 & 12.86 & 63.53 \\
20.50 & 8.62 & 7.99 & 9.40 & 62.11 \\
20.31 & 8.69 & 10.41 & 8.31 & 60.97 \\
19.86 & 8.67 & 13.37 & 7.03 & 59.74 \\
19.62 & 8.79 & 16.48 & 5.75 & 58.15 \\
19.58 & 9.22 & 21.71 & 3.66 & 55.05 \\
20.25 & 10.83 & 30.48 & 1.62 & 47.65 \\
19.96 & 12.61 & 40.28 & 0.23 & 39.53 \\
19.88 & 12.54 & 40.52 & 0.00 & 39.60 \\
30.15 & 11.98 & 0.00 & 6.55 & 63.30 \\
30.67 & 12.34 & 2.68 & 4.42 & 62.23 \\
29.91 & 12.61 & 7.54 & 3.32 & 59.23 \\
29.51 & 13.47 & 14.21 & 2.10 & 54.18 \\
30.03 & 15.87 & 23.70 & 0.78 & 45.49 \\
30.83 & 19.47 & 32.66 & 0.07 & 36.44 \\
30.00 & 18.97 & 33.38 & 0.00 & 36.62 \\
40.00 & 16.37 & 0.00 & 1.61 & 58.39 \\
39.73 & 16.88 & 3.39 & 0.98 & 55.90 \\
39.33 & 19.24 & 12.97 & 0.53 & 47.17 \\
40.83 & 27.37 & 28.20 & 0.01 & 30.96 \\
50.00 & 22.30 & 0.00 & 0.22 & 49.78 \\
48.89 & 24.24 & 7.30 & 0.15 & 43.66 \\
48.95 & 30.20 & 18.72 & 0.01 & 32.32 \\
\hline
\end{tabular}

a[SILOCK-1979D]

Table A-17. Solubility Data for $\mathrm{Fe}\left(\mathrm{NO}_{3}\right)_{3}-\mathrm{Th}\left(\mathrm{NO}_{3}\right)_{4}$ in Nitric Acid-Water at $20^{\circ} \mathrm{C}^{\mathrm{a}}$

\begin{tabular}{ccccc}
\hline $\begin{array}{c}\text { Density, } \\
\text { g/mL }\end{array}$ & $\begin{array}{c}{\left[\mathrm{HNO}_{3}\right],} \\
\text { wt\% }\end{array}$ & $\begin{array}{c}{\left[\mathrm{HNO}_{3}\right],} \\
\mathrm{mol} \%\end{array}$ & $\begin{array}{c}{\left[\mathrm{Fe}\left(\mathrm{NO}_{3}\right)_{3}\right],} \\
\text { wt\% }\end{array}$ & $\begin{array}{c}{\left[\mathrm{Th}\left(\mathrm{NO}_{3}\right)_{4}\right],} \\
\text { wt\% }\end{array}$ \\
\hline 1.92 & 4.93 & 4.35 & 0.00 & 64.06 \\
1.81 & 5.23 & 4.33 & 11.82 & 49.88 \\
1.70 & 5.57 & 4.33 & 21.22 & 38.01 \\
1.59 & 5.96 & 4.54 & 26.33 & 31.90 \\
1.53 & 6.17 & 4.13 & 26.89 & 25.99 \\
1.49 & 6.33 & 4.09 & 29.58 & 21.66 \\
1.44 & 6.54 & 3.98 & 33.95 & 14.44 \\
1.39 & 6.81 & 3.78 & 39.45 & 4.26 \\
1.37 & 6.92 & 3.65 & 40.93 & 0.00 \\
\hline
\end{tabular}

a[SILOCK-1979E] 
Table A-18. Solubility Data for $\mathrm{UO}_{2}\left(\mathrm{NO}_{3}\right)_{2}-\mathrm{Mg}\left(\mathrm{NO}_{3}\right)_{2}$ in Nitric Acid-Water at $25^{\circ} \mathrm{C}^{\mathrm{a}}$

\begin{tabular}{ccccc}
\hline $\begin{array}{c}\text { Density, } \\
\mathrm{g} / \mathrm{mL}\end{array}$ & $\begin{array}{c}{\left[\mathrm{UO}_{2}\left(\mathrm{NO}_{3}\right)_{2}\right],} \\
\mathrm{wt} \%\end{array}$ & $\begin{array}{c}{\left[\mathrm{Mg}\left(\mathrm{NO}_{3}\right)_{2}\right],} \\
\text { wt\% }\end{array}$ & $\begin{array}{c}{\left[\mathrm{UO}_{2}\left(\mathrm{NO}_{3}\right)_{2}\right],} \\
\underline{\mathrm{M}}\end{array}$ & $\begin{array}{c}{\left[\mathrm{Mg}\left(\mathrm{NO}_{3}\right)_{2}\right],} \\
\text { M }\end{array}$ \\
\hline 1.409 & 0.00 & 38.94 & 0.000 & 3.699 \\
1.415 & 4.18 & 35.74 & 0.150 & 3.410 \\
1.448 & 8.21 & 34.34 & 0.302 & 3.353 \\
1.485 & 12.12 & 33.00 & 0.457 & 3.304 \\
1.527 & 16.07 & 30.19 & 0.623 & 3.108 \\
1.543 & 17.73 & 29.88 & 0.694 & 3.109 \\
1.547 & 17.91 & 29.20 & 0.703 & 3.046 \\
1.549 & 18.25 & 29.31 & 0.717 & 3.061 \\
1.548 & 18.29 & 28.67 & 0.719 & 2.992 \\
1.548 & 18.37 & 27.38 & 0.722 & 2.858 \\
1.536 & 18.85 & 26.71 & 0.735 & 2.766 \\
1.532 & 19.49 & 25.26 & 0.758 & 2.609 \\
1.538 & 21.39 & 22.93 & 0.835 & 2.378 \\
1.533 & 23.14 & 20.98 & 0.900 & 2.169 \\
1.538 & 23.90 & 19.46 & 0.933 & 2.018 \\
1.555 & 26.27 & 17.02 & 1.037 & 1.784 \\
1.560 & 27.69 & 16.24 & 1.096 & 1.708 \\
1.563 & 29.41 & 13.91 & 1.167 & 1.466 \\
1.578 & 31.96 & 11.52 & 1.280 & 1.226 \\
1.618 & 38.09 & 7.01 & 1.564 & 0.765 \\
1.657 & 41.60 & 3.56 & 1.749 & 0.398 \\
1.684 & 48.49 & 0.00 & 2.072 & 0.000 \\
\hline
\end{tabular}

a[SILOCK-1979E]

Table A-19. Solubility Data for $\mathrm{UO}_{2}\left(\mathrm{NO}_{3}\right)_{2}-\mathrm{Ca}\left(\mathrm{NO}_{3}\right)_{2}$ in Nitric Acid-Water at $25^{\circ} \mathrm{Ca}$

\begin{tabular}{|c|c|c|c|c|}
\hline $\begin{array}{l}\text { Density, } \\
\mathrm{g} / \mathrm{mL}\end{array}$ & $\begin{array}{c}{\left[\mathrm{UO}_{2}\left(\mathrm{NO}_{3}\right)_{2}\right]} \\
\mathrm{wt} \%\end{array}$ & $\begin{array}{c}{\left[\mathrm{Ca}\left(\mathrm{NO}_{3}\right)_{2}\right]} \\
\text { wt\% }\end{array}$ & $\begin{array}{c}{\left[\mathrm{UO}_{2}\left(\mathrm{NO}_{3}\right)_{2}\right]} \\
\underline{\mathrm{M}}\end{array}$ & $\begin{array}{c}{\left[\mathrm{Ca}\left(\mathrm{NO}_{3}\right)_{2}\right],} \\
\underline{\mathrm{M}}\end{array}$ \\
\hline 1.508 & 0.00 & 48.72 & 0.000 & 4.477 \\
\hline 1.551 & 5.96 & 45.36 & 0.235 & 4.287 \\
\hline 1.582 & 10.18 & 41.68 & 0.409 & 4.018 \\
\hline 1.590 & 10.35 & 40.80 & 0.418 & 3.953 \\
\hline 1.604 & 10.69 & 40.80 & 0.435 & 3.988 \\
\hline 1.604 & 11.28 & 40.29 & 0.459 & 3.938 \\
\hline 1.576 & 12.21 & 38.94 & 0.488 & 3.740 \\
\hline 1.578 & 16.80 & 32.58 & 0.673 & 3.133 \\
\hline 1.584 & 22.03 & 25.87 & 0.886 & 2.497 \\
\hline 1.604 & 29.05 & 18.18 & 1.183 & 1.777 \\
\hline 1.626 & 33.92 & 13.42 & 1.400 & 1.330 \\
\hline 1.650 & 38.72 & 8.15 & 1.621 & 0.820 \\
\hline 1.648 & 39.35 & 6.80 & 1.646 & 0.683 \\
\hline 1.684 & 48.79 & 0.00 & 2.085 & 0.000 \\
\hline
\end{tabular}


Table A-20. Solubility Data for $\mathrm{UO}_{2}\left(\mathrm{NO}_{3}\right)_{2}-\mathrm{Cu}\left(\mathrm{NO}_{3}\right)_{2}$ in Nitric Acid-Water at $25^{\circ} \mathrm{C}^{\mathrm{a}}$

\begin{tabular}{ccccc}
\hline $\begin{array}{c}\text { Density, } \\
\mathrm{g} / \mathrm{mL}\end{array}$ & $\begin{array}{c}{\left[\mathrm{UO}_{2}\left(\mathrm{NO}_{3}\right)_{2}\right],} \\
\mathrm{wt} \%\end{array}$ & $\begin{array}{c}{\left[\mathrm{Cu}\left(\mathrm{NO}_{3}\right)_{2}\right],} \\
\mathrm{wt} \%\end{array}$ & $\begin{array}{c}{\left[\mathrm{UO}_{2}\left(\mathrm{NO}_{3}\right)_{2}\right],} \\
\underline{\mathrm{M}}\end{array}$ & $\begin{array}{c}{\left[\mathrm{Cu}\left(\mathrm{NO}_{3}\right)_{2}\right],} \\
\underline{\mathrm{M}}\end{array}$ \\
\hline 1.709 & 0.00 & 56.43 & 0.000 & 5.142 \\
1.732 & 5.05 & 49.56 & 0.222 & 4.577 \\
1.770 & 10.06 & 47.12 & 0.452 & 4.447 \\
1.806 & 13.94 & 45.29 & 0.639 & 4.361 \\
1.804 & 13.77 & 44.00 & 0.630 & 4.232 \\
1.785 & 13.00 & 43.02 & 0.589 & 4.094 \\
1.745 & 12.63 & 41.63 & 0.559 & 3.873 \\
1.716 & 11.97 & 41.60 & 0.521 & 3.806 \\
1.676 & 12.27 & 38.71 & 0.522 & 3.459 \\
1.672 & 13.26 & 38.50 & 0.563 & 3.432 \\
1.657 & 13.07 & 37.85 & 0.550 & 3.344 \\
1.641 & 14.88 & 34.20 & 0.620 & 2.992 \\
1.619 & 21.68 & 24.87 & 0.891 & 2.147 \\
1.624 & 32.72 & 13.07 & 1.349 & 1.132 \\
1.670 & 40.40 & 6.52 & 1.712 & 0.581 \\
1.684 & 48.79 & 0.00 & 2.085 & 0.000 \\
\hline
\end{tabular}

$\mathrm{a}[\mathrm{SMOCK}-1979 \mathrm{E}]$

Table A-21. Solubility Data for $\mathrm{Ca}\left(\mathrm{NO}_{3}\right)_{2}$ in Nitric Acid-Water at $25^{\circ} \mathrm{C}^{\mathrm{a}}$

\begin{tabular}{ccc}
\hline $\begin{array}{c}\text { [HNO } \\
\text { wt\% } \%,\end{array}$ & $\begin{array}{c}{\left[\mathrm{HNO}_{3}\right],} \\
\mathrm{mol} \%\end{array}$ & $\begin{array}{c}{\left[\mathrm{Ca}\left(\mathrm{NO}_{3}\right)_{2}\right],} \\
\mathrm{wt} \%\end{array}$ \\
\hline 0.00 & 0.00 & 57.40 \\
11.63 & 7.37 & 46.61 \\
21.30 & 13.21 & 38.70 \\
21.72 & 13.48 & 38.44 \\
34.33 & 22.52 & 31.93 \\
33.13 & 22.91 & 35.02 \\
33.94 & 23.37 & 34.27 \\
33.82 & 23.31 & 34.39 \\
39.69 & 27.11 & 29.82 \\
44.55 & 30.78 & 26.83 \\
48.70 & 33.02 & 23.08 \\
57.46 & 37.89 & 15.63 \\
64.80 & 42.58 & 10.23 \\
74.39 & 48.42 & 2.97 \\
86.39 & 64.61 & 0.09 \\
99.99 & 100.00 & 0.01 \\
\hline
\end{tabular}

a[LINKE-1958D] 
Table A-22. Solubility Data for $\mathrm{Ca}\left(\mathrm{NO}_{3}\right)_{2}$ in Nitric Acid-Water at $50^{\circ} \mathrm{C}^{\mathrm{a}}$

\begin{tabular}{ccc}
\hline $\begin{array}{c}{\left[\mathrm{HNO}_{3}\right],} \\
\mathrm{wt} \%\end{array}$ & $\begin{array}{c}{\left[\mathrm{HNO}_{3}\right],} \\
\mathrm{mol} \%\end{array}$ & $\begin{array}{c}{\left[\mathrm{Ca}\left(\mathrm{NO}_{3}\right)_{2}\right],} \\
\mathrm{wt} \%\end{array}$ \\
\hline 0.00 & 0.00 & 77.90 \\
1.46 & 1.81 & 75.93 \\
4.19 & 5.18 & 73.90 \\
5.91 & 7.18 & 72.25 \\
9.83 & 11.09 & 67.65 \\
17.26 & 17.22 & 59.03 \\
25.91 & 23.22 & 49.61 \\
48.89 & 36.09 & 26.37 \\
64.79 & 44.51 & 12.13 \\
75.77 & 51.07 & 3.49 \\
78.76 & 53.78 & 1.90 \\
97.57 & 91.98 & 0.00 \\
\hline
\end{tabular}

a[LINKE-1958E]

Table A-23. Solubility Data for $\mathrm{Ca}\left(\mathrm{NO}_{3}\right)_{2}$ in Nitric Acid-Water at $50^{\circ} \mathrm{C}^{\mathrm{a}}$

\begin{tabular}{ccc}
\hline $\begin{array}{c}{\left[\mathrm{HNO}_{3}\right],} \\
\text { w\% } \%\end{array}$ & $\begin{array}{c}{\left[\mathrm{HNO}_{3}\right],} \\
\mathrm{mol}^{2},\end{array}$ & $\begin{array}{c}{\left[\mathrm{Ca}\left(\mathrm{NO}_{3}\right)_{2}\right],} \\
\text { w\%\% }\end{array}$ \\
\hline 0.59 & 0.71 & 75.80 \\
0.89 & 1.07 & 75.70 \\
1.19 & 1.46 & 75.80 \\
1.52 & 1.74 & 73.90 \\
1.61 & 1.79 & 73.20 \\
1.64 & 1.92 & 74.40 \\
1.87 & 2.15 & 73.80 \\
2.98 & 3.52 & 73.70 \\
7.51 & 8.18 & 68.40 \\
12.32 & 12.66 & 63.40 \\
19.20 & 18.29 & 56.30 \\
23.85 & 21.66 & 51.50 \\
23.85 & 21.39 & 51.10 \\
30.35 & 25.71 & 44.60 \\
30.80 & 26.19 & 44.40 \\
30.90 & 26.02 & 44.00 \\
42.70 & 32.62 & 32.10 \\
57.60 & 39.99 & 17.70 \\
76.40 & 51.57 & 3.10 \\
\hline
\end{tabular}

a[LINKE-1958F] 
Table A-24. Solubility Data for $\mathrm{Ca}\left(\mathrm{NO}_{3}\right)_{2}$ in Nitric Acid-Water at $60^{\circ} \mathrm{C}^{\mathrm{a}}$

\begin{tabular}{ccc}
\hline $\begin{array}{c}{\left[\mathrm{HNO}_{3}\right],} \\
\mathrm{wt} \%\end{array}$ & $\begin{array}{c}{\left[\mathrm{HNO}_{3}\right],} \\
\mathrm{mol} \%\end{array}$ & $\begin{array}{c}{\left[\mathrm{Ca}\left(\mathrm{NO}_{3}\right)_{2}\right],} \\
\mathrm{wt} \%\end{array}$ \\
\hline 0.00 & 0.00 & 78.16 \\
0.91 & 1.17 & 77.19 \\
3.62 & 4.48 & 74.32 \\
6.86 & 8.01 & 70.63 \\
8.48 & 9.73 & 69.05 \\
14.22 & 14.95 & 62.67 \\
19.71 & 19.44 & 56.96 \\
28.50 & 25.24 & 47.38 \\
38.66 & 30.87 & 36.60 \\
50.94 & 37.08 & 24.36 \\
58.66 & 39.88 & 16.07 \\
67.63 & 45.25 & 8.99 \\
77.67 & 52.65 & 2.37 \\
83.20 & 59.22 & 0.43 \\
\hline
\end{tabular}

a[SILOCK-1979F]

Table A-25. Solubility Data for $\mathrm{La}\left(\mathrm{NO}_{3}\right)_{3}$ in Nitric Acid-Water at $25^{\circ} \mathrm{C}^{\mathrm{a}}$

\begin{tabular}{ccc}
\hline $\begin{array}{c}{\left[\mathrm{HNO}_{3}\right],} \\
\mathrm{wt} \%\end{array}$ & $\begin{array}{c}{\left[\mathrm{HNO}_{3}\right],} \\
\mathrm{mol} \%\end{array}$ & $\begin{array}{c}{\left[\mathrm{La}\left(\mathrm{NO}_{3}\right)_{3}\right],} \\
\text { wt\% }\end{array}$ \\
\hline 0.00 & 0.00 & 59.00 \\
3.06 & 2.11 & 56.42 \\
11.95 & 7.58 & 46.42 \\
34.69 & 21.49 & 29.10 \\
40.17 & 27.53 & 29.62 \\
41.14 & 28.06 & 28.73 \\
54.41 & 43.24 & 25.18 \\
58.36 & 45.43 & 21.61 \\
70.70 & 43.25 & 2.79 \\
87.85 & 68.41 & 0.56 \\
90.00 & 72.00 & 0.00 \\
\hline
\end{tabular}

a[LINKE-1965B] 
Table A-26. Solubility Data for $\mathrm{La}\left(\mathrm{NO}_{3}\right)_{3}$ in Nitric Acid-Water at $50^{\circ} \mathrm{C}^{\mathrm{a}}$

\begin{tabular}{ccc}
\hline $\begin{array}{c}{\left[\mathrm{HNO}_{3}\right],} \\
\mathrm{wt} \%\end{array}$ & $\begin{array}{c}{\left[\mathrm{HNO}_{3}\right],} \\
\mathrm{mol \%}\end{array}$ & $\begin{array}{c}{\left[\mathrm{La}\left(\mathrm{NO}_{3}\right)_{3}\right],} \\
\mathrm{wt} \%\end{array}$ \\
\hline 0.00 & 0.00 & 66.65 \\
2.59 & 2.00 & 61.21 \\
5.29 & 4.40 & 61.85 \\
12.05 & 9.92 & 56.70 \\
14.93 & 12.93 & 56.34 \\
27.73 & 22.03 & 44.23 \\
44.48 & 33.52 & 30.31 \\
50.53 & 42.06 & 29.58 \\
78.31 & 57.99 & 5.48 \\
85.51 & 65.08 & 1.38 \\
91.15 & 75.52 & 0.41 \\
90.00 & 72.00 & 0.00 \\
\hline aLINKE-1965B] & &
\end{tabular}

Table A-27. Solubility Data for $\mathrm{NaNO}_{3}$ in Nitric Acid-Water at $35^{\circ} \mathrm{C}^{a}$

\begin{tabular}{ccc}
\hline $\begin{array}{c}{\left[\mathrm{HNO}_{3}\right],} \\
\text { wt\% }\end{array}$ & $\begin{array}{c}{\left[\mathrm{HNO}_{3}\right],} \\
\mathrm{mol} \%\end{array}$ & $\begin{array}{c}{\left[\mathrm{NaNO}_{3}\right],} \\
\text { wt\% }\end{array}$ \\
\hline 0.00 & 0.00 & 50.13 \\
1.40 & 0.79 & 48.20 \\
4.80 & 2.59 & 43.60 \\
8.80 & 4.57 & 38.70 \\
12.70 & 6.35 & 33.80 \\
16.40 & 8.01 & 29.80 \\
23.50 & 11.06 & 22.50 \\
31.90 & 14.77 & 15.50 \\
39.20 & 18.39 & 11.10 \\
47.60 & 23.17 & 7.30 \\
55.40 & 28.61 & 5.10 \\
65.30 & 37.27 & 3.30 \\
70.10 & 42.86 & 3.20 \\
73.40 & 47.26 & 3.20 \\
81.80 & 63.04 & 4.50 \\
84.10 & 69.39 & 5.30 \\
89.90 & 97.72 & 9.50 \\
\hline aYYAKMOV] & &
\end{tabular}


Table A-28. Solubility Data for $\mathrm{NaNO}_{3}$ in Nitric Acid-Water at $50^{\circ} \mathrm{C}^{\mathrm{a}}$

\begin{tabular}{ccc}
\hline $\begin{array}{c}{\left[\mathrm{HNO}_{3}\right],} \\
\mathrm{wt} \%\end{array}$ & $\begin{array}{c}{\left[\mathrm{HNO}_{3}\right],} \\
\mathrm{mol} \%\end{array}$ & $\begin{array}{c}{\left[\mathrm{NaNO}_{3}\right],} \\
\mathrm{wt} \%\end{array}$ \\
\hline 0.00 & 0.00 & 53.60 \\
10.00 & 5.50 & 40.90 \\
18.40 & 9.65 & 32.40 \\
28.50 & 14.05 & 21.70 \\
37.90 & 18.73 & 15.10 \\
49.00 & 25.04 & 9.10 \\
59.80 & 32.99 & 5.50 \\
72.80 & 47.17 & 3.90 \\
79.60 & 58.55 & 4.30 \\
87.90 & 81.77 & 6.50 \\
90.20 & 98.47 & 9.40 \\
\hline
\end{tabular}

a[YAKIMOV]

Table A-29. Solubility Data for $\mathrm{NaNO}_{3}$ in Nitric Acid-Water at $75^{\circ} \mathrm{C}^{\mathrm{a}}$

\begin{tabular}{ccc}
\hline $\begin{array}{c}{\left[\mathrm{HNO}_{3}\right],} \\
\text { wt\% }\end{array}$ & $\begin{array}{c}{\left[\mathrm{HNO}_{3}\right],} \\
\mathrm{mol} \%\end{array}$ & $\begin{array}{c}{\left[\mathrm{NaNO}_{3}\right],} \\
\mathrm{wt} \%\end{array}$ \\
\hline 0.00 & 0.00 & 58.30 \\
17.20 & 9.99 & 38.50 \\
30.50 & 16.56 & 25.60 \\
38.00 & 20.42 & 19.70 \\
41.70 & 22.47 & 17.20 \\
63.70 & 38.16 & 6.80 \\
70.80 & 46.79 & 6.20 \\
78.30 & 58.61 & 5.90 \\
87.00 & 81.61 & 7.40 \\
87.70 & 84.49 & 7.70 \\
88.90 & 89.44 & 8.10 \\
\hline
\end{tabular}

${ }^{\mathrm{a}}[\mathrm{SILOCK}-1979 \mathrm{G}]$

Table A-30. Solubility Data for $\mathrm{Sm}\left(\mathrm{NO}_{3}\right)_{3}$ in Nitric Acid-Water at $25^{\circ} \mathrm{C}^{\mathrm{a}}$

\begin{tabular}{ccc}
\hline $\begin{array}{c}{\left[\mathrm{HNO}_{3}\right],} \\
\mathrm{wt} \%\end{array}$ & $\begin{array}{c}{\left[\mathrm{HNO}_{3}\right],} \\
\mathrm{mol} \%\end{array}$ & $\begin{array}{c}{\left[\mathrm{Sm}\left(\mathrm{NO}_{3}\right)_{3}\right],} \\
\mathrm{wt} \%\end{array}$ \\
\hline 0.00 & 0.00 & 58.95 \\
6.15 & 4.04 & 52.08 \\
11.34 & 7.14 & 46.52 \\
44.38 & 24.43 & 16.40 \\
48.40 & 26.99 & 14.20 \\
51.58 & 29.76 & 13.64 \\
\hline
\end{tabular}

a[SILOCK-1979H] 
Table A-31. Solubility Data for $\mathrm{Sm}\left(\mathrm{NO}_{3}\right)_{3}$ in Nitric Acid-Water at $50^{\circ} \mathrm{C}$

\begin{tabular}{ccc}
\hline $\begin{array}{c}{\left[\mathrm{HNO}_{3}\right],} \\
\mathrm{wt} \%\end{array}$ & $\begin{array}{c}{\left[\mathrm{HNO}_{3}\right],} \\
\mathrm{mol} \%\end{array}$ & $\begin{array}{c}{\left[\mathrm{Sm}\left(\mathrm{NO}_{3}\right)_{3}\right],} \\
\text { wt\% }\end{array}$ \\
\hline 0.00 & 0.00 & 64.81 \\
2.12 & 1.71 & 62.97 \\
7.53 & 5.81 & 57.57 \\
22.38 & 16.41 & 45.05 \\
36.40 & 25.49 & 33.20 \\
47.52 & 37.89 & 30.22 \\
46.21 & 33.76 & 27.89 \\
\hline a[SILOCK-1979H]
\end{tabular}

Table A-32. Solubility Data for $\mathrm{UO}_{2}\left(\mathrm{NO}_{3}\right)_{2}$ in Nitric Acid-Water at $25^{\circ} \mathrm{C}^{\mathrm{a}}$

\begin{tabular}{ccc}
\hline $\begin{array}{c}{\left[\mathrm{HNO}_{3}\right],} \\
\mathrm{wt} \%\end{array}$ & $\begin{array}{c}{\left[\mathrm{HNO}_{3}\right],} \\
\mathrm{mol} \%\end{array}$ & $\begin{array}{c}{\left[\mathrm{UO}_{2}\left(\mathrm{NO}_{3}\right)_{3}\right],} \\
\text { wt\% }\end{array}$ \\
\hline 0.00 & 0.00 & 56.08 \\
12.35 & 6.94 & 40.36 \\
25.14 & 13.88 & 30.29 \\
28.67 & 16.43 & 29.65 \\
29.84 & 17.98 & 31.27 \\
30.43 & 20.93 & 36.72 \\
30.15 & 21.28 & 37.99 \\
32.31 & 22.71 & 36.28 \\
46.12 & 33.04 & 27.18 \\
50.43 & 37.73 & 25.79 \\
53.20 & 43.15 & 26.77 \\
53.71 & 44.94 & 27.49 \\
55.24 & 47.39 & 27.24 \\
60.38 & 51.93 & 23.65 \\
66.71 & 63.41 & 22.29 \\
68.83 & 69.38 & 22.49 \\
\hline
\end{tabular}

a[SILOCK-1979I] 
Table A-33. Solubility Data for $\mathrm{UO}_{2}\left(\mathrm{NO}_{3}\right)_{2}$ in Nitric Acid-Water at $49.1^{\circ} \mathrm{C}$

\begin{tabular}{ccc}
\hline $\begin{array}{c}{\left[\mathrm{HNO}_{3}\right],} \\
w t \%\end{array}$ & $\begin{array}{c}{\left[\mathrm{HNO}_{3}\right],} \\
\mathrm{mol} \%\end{array}$ & $\begin{array}{c}{\left[\mathrm{UO}_{2}\left(\mathrm{NO}_{3}\right)_{3}\right],} \\
\text { wt\% }\end{array}$ \\
\hline 5.10 & 4.24 & 62.00 \\
3.20 & 2.64 & 63.10 \\
5.40 & 4.59 & 62.50 \\
11.30 & 9.80 & 59.00 \\
10.70 & 9.88 & 61.40 \\
10.90 & 8.79 & 56.80 \\
12.40 & 11.71 & 60.90 \\
13.10 & 12.54 & 60.80 \\
19.70 & 17.97 & 54.60 \\
19.70 & 18.44 & 55.40 \\
25.50 & 22.57 & 49.50 \\
27.20 & 24.01 & 48.20 \\
28.20 & 25.13 & 47.80 \\
30.80 & 27.76 & 46.30 \\
30.00 & 26.64 & 46.40 \\
33.40 & 31.55 & 45.90 \\
34.10 & 32.43 & 45.60 \\
35.80 & 34.06 & 44.40 \\
36.30 & 36.56 & 45.70 \\
37.90 & 34.35 & 41.40 \\
40.60 & 38.28 & 40.70 \\
48.60 & 48.24 & 36.50 \\
49.50 & 49.20 & 35.90 \\
52.30 & 54.06 & 35.00 \\
63.50 & 63.34 & 26.00 \\
80.20 & 75.09 & 12.20 \\
80.70 & 77.75 & 12.70 \\
83.00 & 77.97 & 10.30 \\
85.50 & 81.16 & 8.83 \\
\hline
\end{tabular}

a[SILOCK-1979]] 
Table A-34. Solubility Data for $\mathrm{UO}_{2}\left(\mathrm{NO}_{3}\right)_{2}$ in Nitric Acid-Water at $50^{\circ} \mathrm{C}^{\mathrm{a}}$

\begin{tabular}{ccc}
\hline $\begin{array}{c}{\left[\mathrm{HNO}_{3}\right],} \\
\text { wt\% }\end{array}$ & $\begin{array}{c}{\left[\mathrm{HNO}_{3}\right],} \\
\mathrm{mol} \%\end{array}$ & $\begin{array}{c}{\left[\mathrm{UO}_{2}\left(\mathrm{NO}_{3}\right)_{3}\right],} \\
\text { wt\% }\end{array}$ \\
\hline 0.15 & 0.14 & 69.15 \\
0.60 & 0.54 & 68.10 \\
5.30 & 5.01 & 66.00 \\
5.20 & 4.84 & 65.60 \\
8.10 & 7.95 & 65.10 \\
8.40 & 8.48 & 65.70 \\
10.40 & 10.29 & 63.70 \\
10.60 & 10.47 & 63.50 \\
13.10 & 12.76 & 61.30 \\
13.00 & 12.54 & 61.10 \\
15.40 & 14.29 & 58.20 \\
24.00 & 21.66 & 51.20 \\
27.60 & 24.73 & 48.40 \\
30.10 & 27.56 & 47.30 \\
30.10 & 27.39 & 47.10 \\
32.10 & 29.33 & 45.80 \\
35.50 & 34.80 & 45.50 \\
36.40 & 35.62 & 44.80 \\
38.00 & 37.49 & 43.90 \\
38.90 & 38.04 & 43.00 \\
41.80 & 40.56 & 40.70 \\
44.60 & 43.28 & 38.70 \\
50.50 & 49.03 & 34.50 \\
60.00 & 61.79 & 29.40 \\
63.80 & 70.03 & 28.40 \\
65.00 & 72.91 & 28.10 \\
64.40 & 74.49 & 29.30 \\
62.50 & 83.61 & 34.00 \\
57.00 & 89.06 & 41.00 \\
54.40 & 90.67 & 44.00 \\
53.00 & 88.85 & 45.10 \\
53.20 & 92.12 & 45.50 \\
55.30 & 98.75 & 44.50 \\
\hline & & \\
\hline
\end{tabular}

a[SILOCK-1979B] 


\section{References for Appendix A}

\section{LINKE-1958A}

William F. Linke, Solubilities, Inorganic and Metal-Organic Compounds: A Compilation of Solubility Data from the Periodical Literature, 4th Ed., Vol. I, McGregor \& Werner Inc., Washington, DC (1958). First published by K. Inamura, Mem. Coll. Sci., Kyoto, Imp. Univ., 3, 105 (1919).

LINKE-1958B

William F. Linke, Solubilities, Inorganic and Metal-Organic Compounds: A Compilation of Solubility Data from the Periodical Literature, 4th Ed., Vol. I, McGregor \& Werner Inc., Washington, DC (1958). First published by H. Bassett, Jr. and H. S. Taylor, J. Chem. Soc. (London) 101, 576 (1912).

\section{LINKE-1958C}

William F. Linke, Solubilities, Inorganic and Metal-Organic Compounds: A Compilation of Solubility Data from the Periodical Literature, 4th Ed., Vol. I, McGregor \& Werner Inc., Washington, DC (1958). First published by L. H. Milligan, J. Amer. Chem. Soc. 44, 567-570 (1922).

\section{LINKE-1958D}

William F. Linke, Solubilities, Inorganic and Metal-Organic Compounds: A Compilation of Solubility Data from the Periodical Literature, 4th Ed., Vol. I, McGregor \& Werner Inc., Washington, DC (1958). First published by R. Flatt and P. Fritz, Helv. Chim. Acta. $\underline{33}, 2045$ (1950).

\section{LINKE-1958E}

William F. Linke, Solubilities, Inorganic and Metal-Organic Compounds: A Compilation of Solubility Data from the Periodical Literature, 4th Ed., Vol. I, McGregor \& Werner Inc., Washington, DC (1958). First published by A. P. Belopolskii and V. V. Urusov, Zhur. Priklad. Khim. 10, 1178 (1937).

\section{LINKE-1958F}

William F. Linke, Solubilities, Inorganic and Metal-Organic Compounds: A Compilation of Solubility Data from the Periodical Literature, 4th Ed., Vol. I, McGregor \& Werner Inc., Washington, DC (1958). First published by R. Flatt, G. Brunisholz, and A. Denereaz, Helv. Chim. Acta. 39, 473 (1956).

\section{LINKE-1965A}

William F. Linke, Solubilities, Inorganic and Metal-Organic Compounds: A Compilation of Solubility Data from the Periodical Literature, 4th Ed., Vol. II, American Chemical Society, Washington, DC (1965). First published by A. Sieverts and L. Z. Schreiner, Anorg. Chem. $\underline{219}, 105$ (1934).

\section{LINKE-1965B}

William F. Linke, Solubilities, Inorganic and Metal-Organic Compounds: A Compilation of Solubility Data from the Periodical Literature, 4th Ed., Vol. II, American Chemical Society, Washington, DC (1965). First published by L. L. Quill and R. F. Robey, J. Am. Chem. Soc. 59, 1071 (1937). 


\section{SIEKIERSKI-1966A}

S. Siekierski, T. Mioduski, and M. Salomon, Solubility Data Series, Vol. 13, Scandium, Yttrium, Lanthanum, and Lanthanide Nitrates, Pergamon Press, Oxford (1983). First published by K. E. Mironov, A. P. Popov, and L. A. Khripin, Zh. Neorg. Khim. 11, 2789 (1966).

\section{SIEKIERSKI-1966B}

S. Siekierski, T. Mioduski, and M. Salomon, Solubility Data Series, Vol. 13, Scandium, Yttrium, Lanthanum, and Lanthanide Nitrates, Pergamon Press, Oxford (1983). First published by K. E. Mironov, E. D. Sinitsyna, and A. P. Popov, Zh. Neorg. Khim. 11, 2361 (1966).

\section{SILOCK-1979A}

Howard Silock, Solubilities of Inorganic Compounds: Ternary and Multi-component Systems of Inorganic Substances, Part 1, Vol. 3, Pergamon, Oxford (1979). First published by G. Malquori, Atti accad. Lincei 9 (6), 569 (1929).

\section{SILOCK-1979B}

Howard Silock, Solubilities of Inorganic Compounds: Ternary and Multi-component Systems of Inorganic Substances, Part 1, Vol. 3, Pergamon, Oxford (1979). First published by M. A. Yakimov and V. Ya. Mishin, Radiokhimiya $\underline{6}$ (4), 454 (1964).

\section{SILOCK-1979C}

Howard Silock, Solubilities of Inorganic Compounds: Ternary and Multi-component Systems of Inorganic Substances, Part 1, Vol. 3, Pergamon, Oxford (1979). First published by V. I. Nikolaev, Zh. Russ. Fiz.-Khim. Obshchest. 60, 893 (1928).

\section{SILOCK-1979D}

Howard Silock, Solubilities of Inorganic Compounds: Ternary and Multi-component Systems of Inorganic Substances, Part 1, Vol. 3, Pergamon, Oxford (1979). First published by G. S. Sedel'Nikov and S. B. Stepina, Tr. Mosk. Inst. Tonkoi Khim. Tecknol. vyp. Z, 102 (1958).

\section{SILOCK-1979E}

Howard Silock, Solubilities of Inorganic Compounds: Ternary and Multi-component Systems of Inorganic Substances, Part 1, Vol. 3, Pergamon, Oxford (1979). First published by A. G. Kurnakova and A. V. Nikolaev, Zh. Neorgan. Khim. $\underline{3}$ (4), 1028 (1958).

\section{SILOCK-1979F}

Howard Silock, Solubilities of Inorganic Compounds: Ternary and Multi-component Systems of Inorganic Substances, Part 1, Vol. 3, Pergamon, Oxford (1979). First published by A. V. Rusadze and S. Ya. Shpunt, Zh. Neorgan. Khim. 4 (1), 182 (1959).

\section{SILOCK-1979G}

Howard Silock, Solubilities of Inorganic Compounds: Ternary and Multi-component Systems of Inorganic Substances, Part 1, Vol. 3, Pergamon, Oxford (1979). First published by A. A. Kazantsev, Izv. Vses. Nauch-Issled. Inst. Khim. Reaktivov Osobo Chist. Khim. Veschchestv. 2, 10 (1923). 
SILOCK-1979H

Howard Silock, Solubilities of Inorganic Compounds: Ternary and Multi-component Systems of Inorganic Substances, Part 1, Vol. 3, Pergamon, Oxford (1979). First published by L. L. Quill and R. F. Robey, J. Am. Chem. Soc. 59, 1071 \& 2591 (1937).

SILOCK-1979I

Howard Silock, Solubilities of Inorganic Compounds: Ternary and Multi-component Systems of Inorganic Substances, Part 1, Vol. 3, Pergamon, Oxford (1979). First published by A. Colani, Bull. Soc. Chim. 39, 1243 (1926).

SILOCK-1979J

Howard Silock, Solubilities of Inorganic Compounds: Ternary and Multi-component Systems of Inorganic Substances, Part 1, Vol. 3, Pergamon, Oxford (1979). First published by J.

Gaunt, J. Bastien, and M. Adelman, Canadian J. Chem. 41, 527 (1963).

WEAST

Robert C. Weast, Handbook of Chemistry and Physics, CRC Press, Cleveland (1974).

\section{YAKIMOV}

M. A. Yakimov, V. Ya. Mishin, and E. V. Zalkind, "The Sodium Nitrate-Nitric Acid-Water System at $25^{\circ}, 35^{\circ}$ and $50^{\circ}, "$ Russian J. Inorg. Chem. 11(8), 1032 (1966). 


\section{APPENDIX B}

\section{Vapor-Liquid Equilibrium Data}

The composition of the TRUEX waste streams consist mainly of aqueous nitric acid solutions containing metal nitrate salts. Therefore, to design the evaporator for concentrating specific TRUEX waste streams it is important to know the concentrations of water and nitric acid in the liquid and vapor phases as a function of temperature, pressure, and composition of the aqueous solution. However, some solutions may also contain other acids such as sulfuric, phosphoric, hydrofluoric, and oxalic, and it is important to understand the effects of these acids on the system as well.

A literature survey was performed on the effects of metal nitrate salts on the vapor-liquid equilibria of aqueous $\mathrm{HNO}_{3}$ solutions. The most useful source was a set of five books by Wichterle et al. [WICHTERLE-1973, -1976, -1979, -1982, -1985] which has information on almost 8500 vaporliquid equilibrium systems studied from 1900 through 1984. Many applicable references were obtained from this source for both nitric acid-water and nitric acid-water-nitrate salt systems. The nitrate salts studied were those present in the largest concentrations in the Hanford waste streams: nitrate salts of $\mathrm{Al}^{3+}, \mathrm{Ca}^{2+}, \mathrm{Fe}^{3+}, \mathrm{La}^{3+}, \mathrm{Na}^{+}, \mathrm{Ni}^{2+}$, and $\mathrm{UO}_{2}{ }^{2+}$.

To aid the reader to find information in this appendix, the following two tables were generated: Table B-1 summarizes the systems displayed in each figure. Table B-2 contains a list of the systems reported in each table. For clarity, all of the data tables were moved to the end of this appendix.

Table B-1. List of Systems Displayed in Figures

\begin{tabular}{llcc}
\hline No. & System & Pressure, $\mathrm{mmHg}$ & Page \\
\hline B-1. & Nitric Acid-Water & 760 & 87 \\
B-2. & Nitric Acid-Water & 760 & 87 \\
B-3. & Nitric Acid-Water & $50,100,760$ & 88 \\
B-4. & Nitric Acid-Water & Various Pressures & 88 \\
B-5. & Nitric Acid-Water La, Ni, \& Na & 400 & 89 \\
B-6. & Nitric Acid-Aluminum Nitrate & 130 & 90 \\
B-7. & Nitric Acid-Sodium Nitrate & 760 & 90 \\
B-8. & Nitric Acid-Sodium Nitrate & 760 & 91 \\
B-9. & HNO $_{3}$ - $\mathrm{H}_{2} \mathrm{O}_{-} \mathrm{UO}_{2}\left(\mathrm{NO}_{3}\right)_{2}$ & & 92 \\
B-10. & Nitric Acid-Water-Sodium Nitrate & & 92 \\
B-11. & Sulfuric Acid-Water & 760 & 94 \\
B-12. & Phosphoric Acid vs. Water Activity & 760 & 95 \\
B-13. & Nitric-Sulfuric-Water & 760 & 96 \\
B-14. & Nitric-Sulfuric-Water & & 96 \\
\hline
\end{tabular}


Table B-2. List of Systems Described in Tables

\begin{tabular}{|c|c|c|c|}
\hline No. & System & Pressure, $\mathrm{mmHg}$ & Page \\
\hline B-3. & Nitric Acid-Water & 760 & 97 \\
\hline B-4. & Nitric Acid-Water & 760 & 97 \\
\hline B-5. & Nitric Acid-Water & 760 & 98 \\
\hline B-6. & Nitric Acid-Water & 760 & 99 \\
\hline B-7. & Nitric Acid-Water & 50 & 100 \\
\hline B-8. & Nitric Acid-Water & 100 & 100 \\
\hline B-9. & Nitric Acid-Water & 200 & 101 \\
\hline B-10. & Nitric Acid-Water & 400 & 101 \\
\hline B-11. & Nitric Acid-Water & 450 & 102 \\
\hline B-12. & Nitric Acid-Water & 600 & 103 \\
\hline B-13. & Comparison of Salting Out Capacity of $6 \mathrm{~mol} \% \mathrm{La}, \mathrm{Ni}, \& \mathrm{Na}$ & 400 & 104 \\
\hline B-14. & Aluminum Nitrate & 30 & 104 \\
\hline B-15. & Sodium Nitrate & 760 & 105 \\
\hline B-16. & $\mathrm{HNO}_{3}-\mathrm{H}_{2} \mathrm{O}-\mathrm{UO}_{2}\left(\mathrm{NO}_{3}\right)_{2}$ & $180,360,720$ & 106 \\
\hline B-17. & Sulfuric Acid & & 107 \\
\hline B-18. & Constants for Water-Sulfuric Acid Fit & & 109 \\
\hline B-19. & Water Activity over Aqueous Phophoric Acid at $25^{\circ} \mathrm{C}$ & & 110 \\
\hline B-20. & Nitric Acid-Water Sulfuric Acid & 760 & 111 \\
\hline
\end{tabular}

\section{Conventions}

The following two conventions will be used in presenting data in the literature survey.

1. When data are plotted as a function of mol\% nitric acid, this means mol\% of nitric acid in solution with the salt removed, which is described by

$$
\mathrm{mol} \% \mathrm{HNO}_{3} \text { (salt-free) }=\frac{\mathrm{mol} \mathrm{HNO}_{3}}{\mathrm{~mol} \mathrm{HNO}_{3}+\mathrm{mol} \mathrm{H}_{2} \mathrm{O}} \cdot 100
$$

For example, a solution containing $10 \mathrm{~mol}$ nitrate salt, $30 \mathrm{~mol}$ nitric acid, and $60 \mathrm{~mol}$ water would actually have $10 \mathrm{~mol} \%$ nitrate salt, $30 \mathrm{~mol} \%$ nitric acid, and $60 \mathrm{~mol} \%$ water. The $\mathrm{mol} \% \mathrm{HNO}_{3}$ (salt-free) would be equal to $33.33 \mathrm{~mol} \%$.

2. Additionally, the variables $x$ and $y$ will be used to represent the concentration of nitric acid in the liquid and vapor phases respectively.

\section{Binary Nitric Acid-Water Systems}

To understand the effects that salts have on nitric acid-water-salt systems, it is useful to first understand the binary system. According to Ellis and Thwaites [ELLIS], at atmospheric pressure the azoetropic composition of nitric acid-water system is 38.65 mol\% $\mathrm{HNO}_{3}$ with a boiling temperature of $120.1^{\circ} \mathrm{C}$. Data from Boublik et al. [HALA-1960], Prosek [HALA-1968], and Potier and Alger [HALA-1958] for this system at atmospheric pressure were also obtained. The data from these four authors are listed in Tables B-3 through B-6. The boiling temperature versus the nitric acid concentration in the liquid phase is plotted in Fig. B-1, and the concentration of nitric acid in the vapor phase versus the concentration of nitric acid in the liquid phase is plotted in Fig. B-2.

Figures B-1 and -2 show that all the data agree very well at atmospheric pressure. 


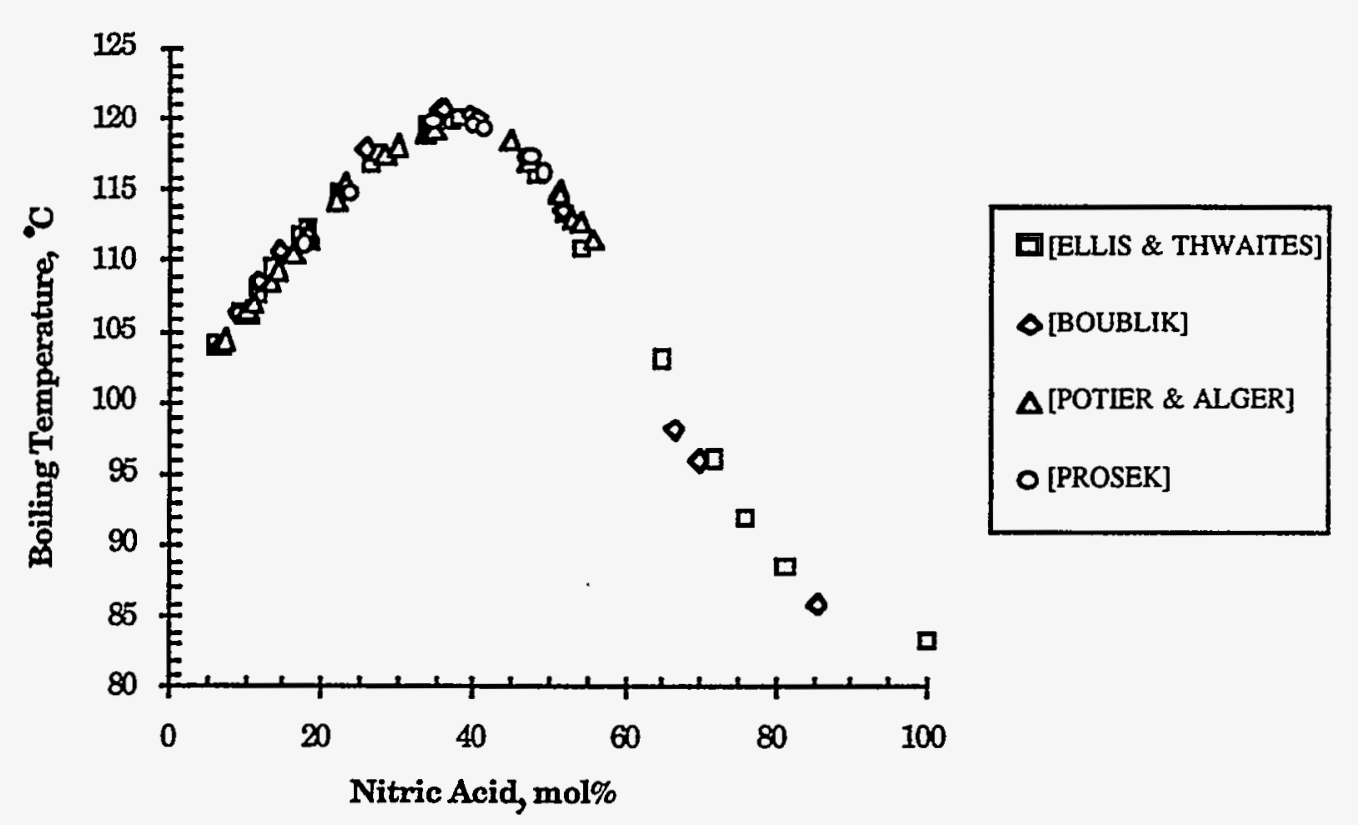

Fig. B-1. Comparison of Boiling-Temperature Data for Nitric AcidWater System at $760 \mathrm{mmHg}$

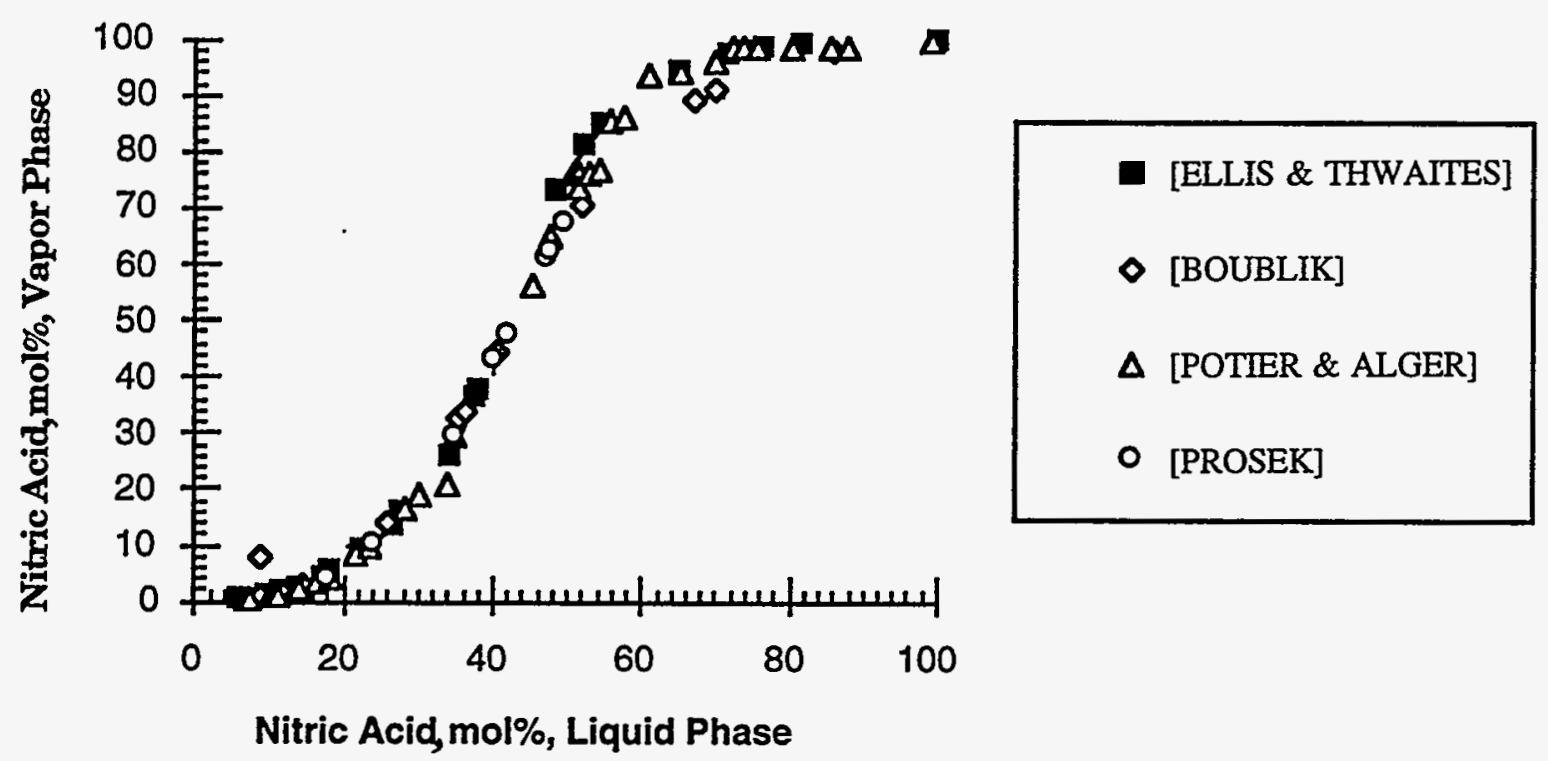

Fig. B-2. Comparison of Vapor and Liquid Composition Data for Nitric AcidWater System at $760 \mathrm{mmHg}$

Boublik et al. [HALA-1960] also conducted experiments at pressures of 50, 100, 200, 400, and $450 \mathrm{mmHg}$, and Potier \& Alger [HALA-1958] conducted an experiment at $600 \mathrm{mmHg}$. From these data, plotted in Fig B-3 and B-4 and listed in Tables B-7 through B-12, it is evident that decreasing the pressure only reduces the temperature at which the system will boil for a given acid concentration. Note that, for clarity, only data for three different pressures are plotted in Fig. B-3. They are sufficient to show the trends as the pressure changed. 


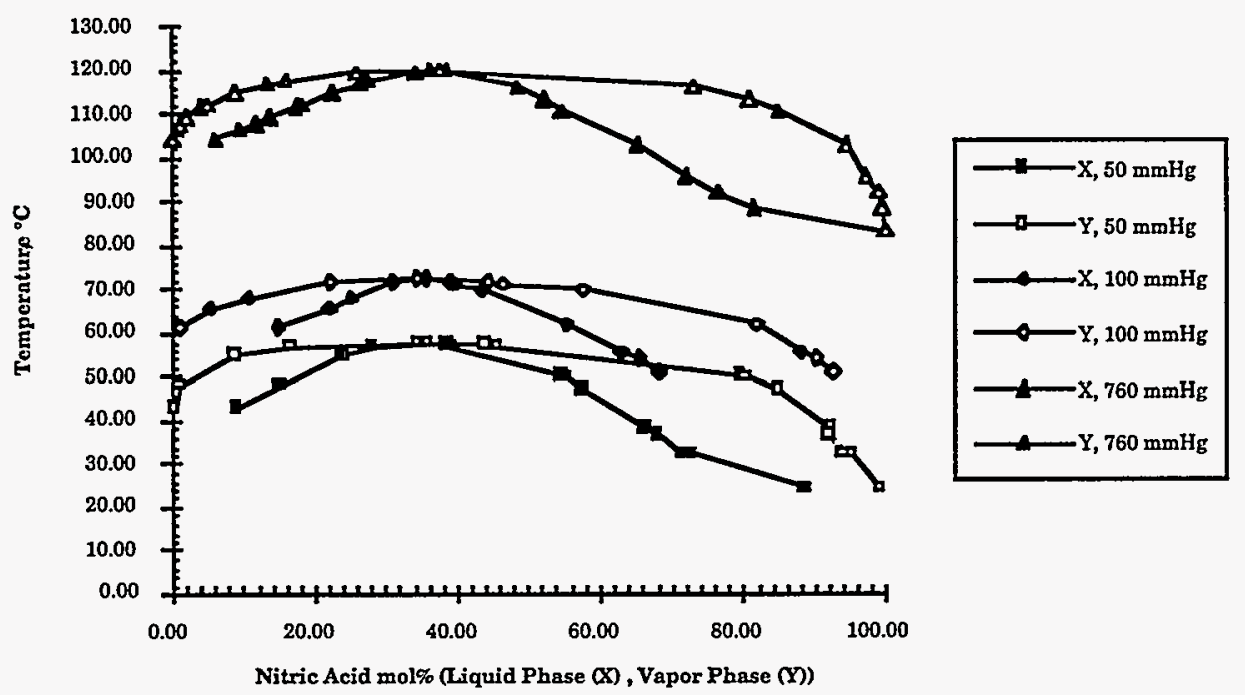

Fig. B-3. Comparison of Binary Nitric Acid-Water System at 50, 100, and $760 \mathrm{mmHg}$

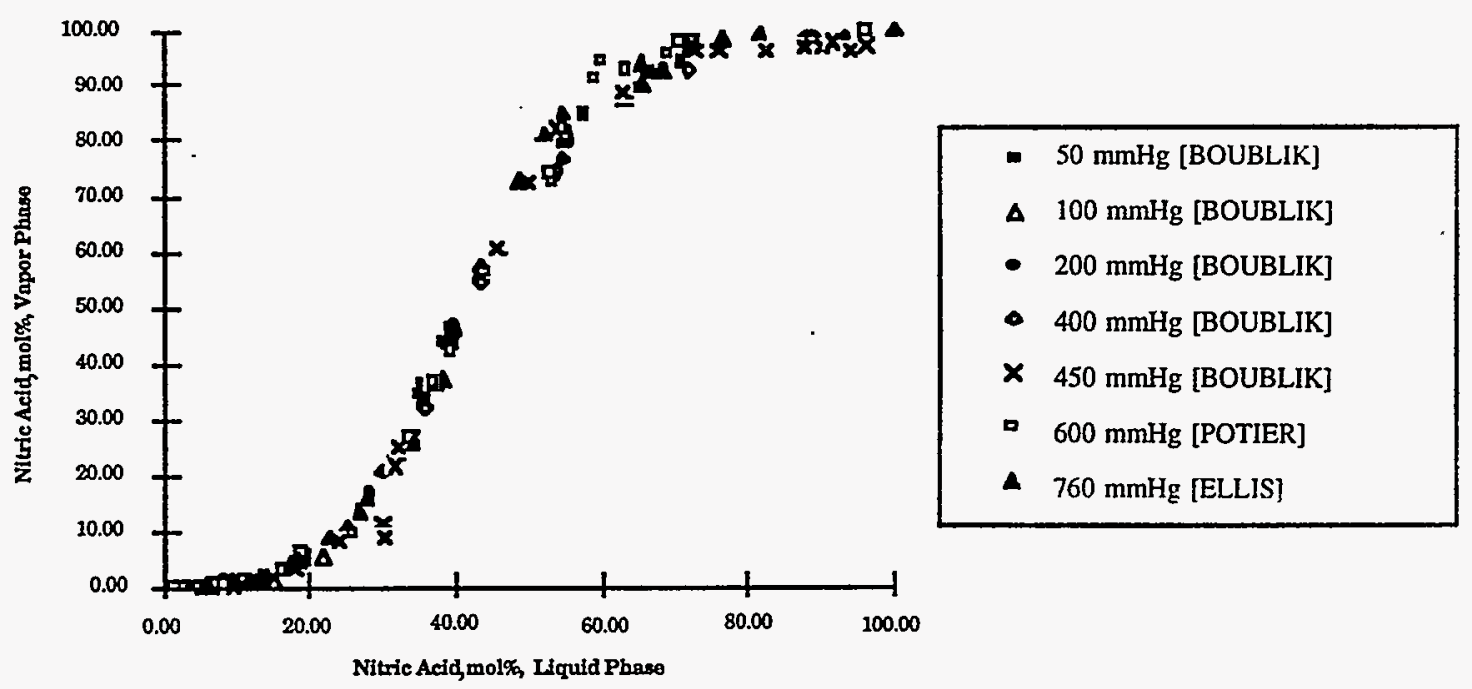

Fig. B-4. Comparison of Binary Nitric Acid-Water System at Various Pressures

\section{Ternary Systems (Effect of Salts)}

For multicomponent systems, such as nitric acid-water-nitrate salt, the vapor-liquid equilibrium is affected by two variables. One is the composition of the aqueous solution, which effects the activities of water and nitric acid. The second is the pressure of the system, which primarily effects the boiling temperature.

Except for potassium nitrate, the presence of salts in the nitric acid-water system tends to salt out the nitric acid into the vapor phase, thus enriching it in nitric acid. In terms of thermodynamics, salting out is equivalent to increasing the activity of $\mathrm{HNO}_{3}$ and decreasing the activity of water. Barnov et al. [BARNOV] investigated the vapor-liquid equilibria of 13 nitric acidwater-nitrate salt systems at atmospheric pressure. Nitrate salts included potassium, sodium, lithium, 
barium, strontium, calcium, magnesium, mercury, cadmium, zinc, manganese, cobalt, and nickel. He concluded that the salting-out capacity of salts can be related to the square root of the charge-toradius ratio. Polovnikova et al. [POLOVNIKOVA] studied 16 ternary systems of nitric acid-watersulfates at atmospheric pressure. Sulfate salts included lithium, sodium, potassium, zinc, cadmium, mercury, copper, manganese, cobalt, nickel, lanthanum, yttrium, scandium, indium, gallium, and aluminum. Polovnikova et al. suggest that the salting-out capacity of sulfates shows trends similar to the nitrates. Using the information from Barnov et al. and Polovnikova et al., we can show that the salting-out capacity of the salts of interest in this project is as follows: $\mathrm{Al}>\mathrm{La}>\mathrm{Ni}>\mathrm{Ca}>\mathrm{Na}$. This trend can be verified for $\mathrm{La}, \mathrm{Ni}$, and $\mathrm{Na}$ by plotting experimental data from Efimov et al. [EFIMOV1974, EFIMOV-1975]. The plot is shown in Fig. B-5, and the data are listed in Table B-13.

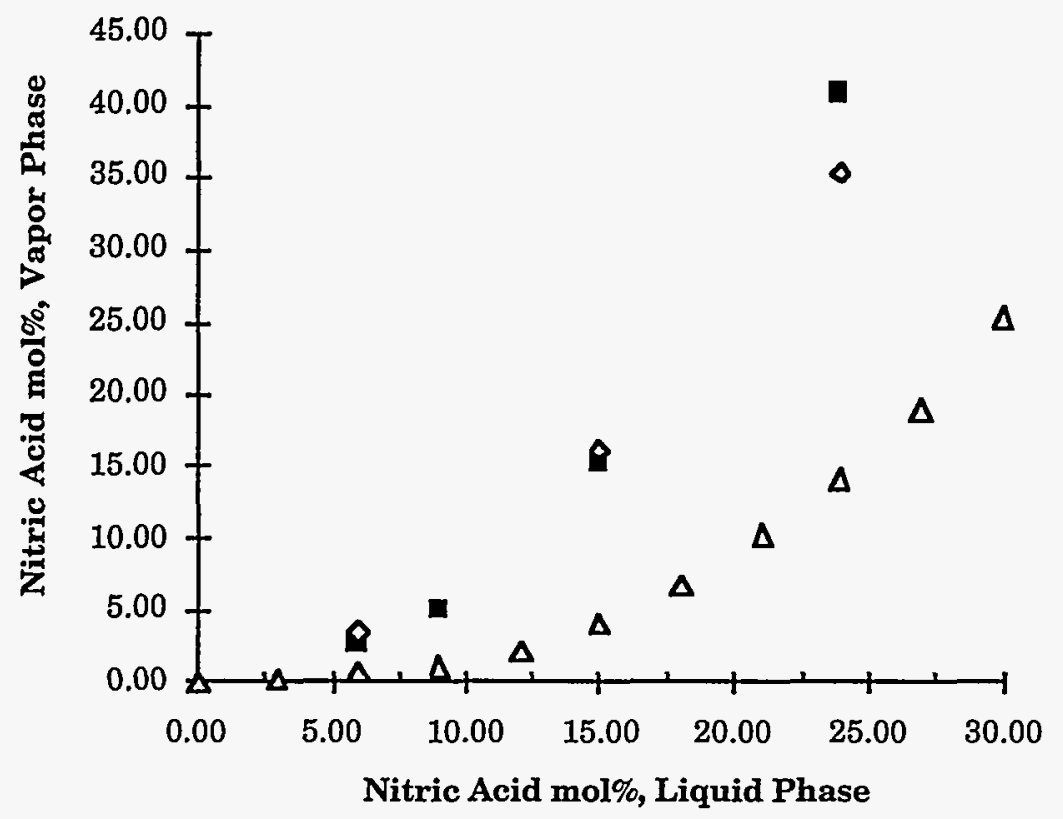

Fig. B-5. Comparison of Salting-Out Capacity for $6 \mathrm{~mol} \% \mathrm{La}, \mathrm{Ni}$, and $\mathrm{Na}$ at $400 \mathrm{mmHg}$

Although data were available for other salt systems, we could not make similar comparisons, since data were either obtained at different pressures or for different salt concentrations.

According to Efimov et al. [EFIMOV-1970], the nitrates salt out basically because of two factors. First, the salts hydrate, which is equivalent to decreasing the activity of $\mathrm{H}_{2} \mathrm{O}$. Second, the ionic equilibrium of the nitric acid shifts under the influence of the common ion, $\mathrm{NO}_{3}^{-}$, introduced with the salt (increasing the activity of nitrate and, therefore, nitric acid). Both factors lead to an increase in the effective concentration of nitric acid in the liquid and consequently, in the equilibrium vapors.

While it is important to understand the relative salting-out capacities of different salts, it is also as important, if not more so, to know how the vapor-liquid equilibrium for nitric acid-waternitrate salt system changes as the concentration of the salt increases. With all the salts studied, it was found that increasing the salt concentration while maintaining a constant pressure increases both the concentration of acid in the vapor phase and the solution boiling point, while decreasing the azeotropic point. The change in vapor-phase composition of nitric acid is illustrated in Fig. B-6 for 


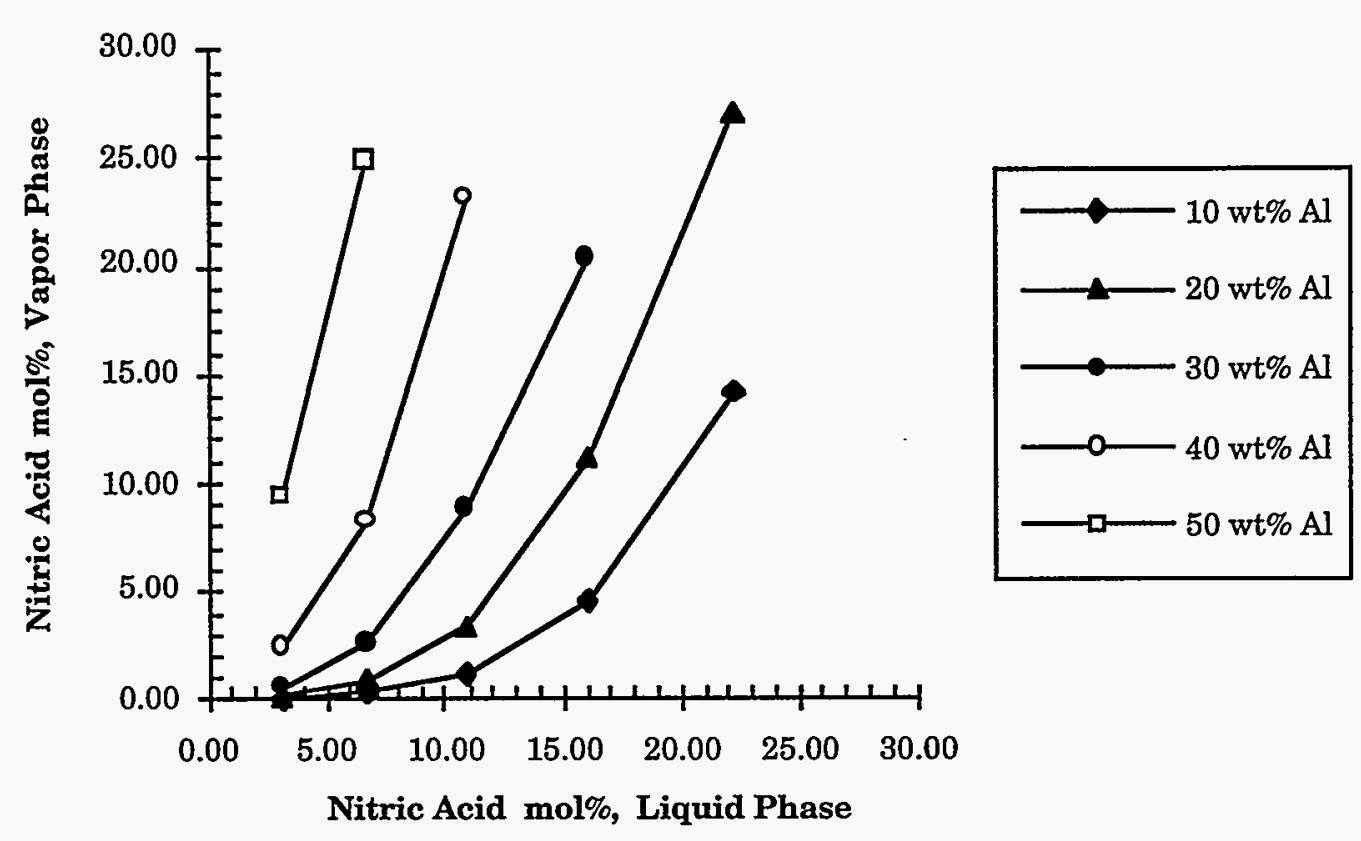

Fig. B-6. Concentration of Nitric Acid in the Vapor Phase as a Function of the Concentration in the Liquid Phase of Aluminum Nitrate at $130 \mathrm{mmHg}$

aluminum nitrate at $130 \mathrm{mmHg}$ [EFIMOV-1975] and in Fig. B-7 for sodium nitrate at $760 \mathrm{mmHg}$ [EFIMOV-1974]. The data are listed in Table B-14 and Table B-15, respectively.

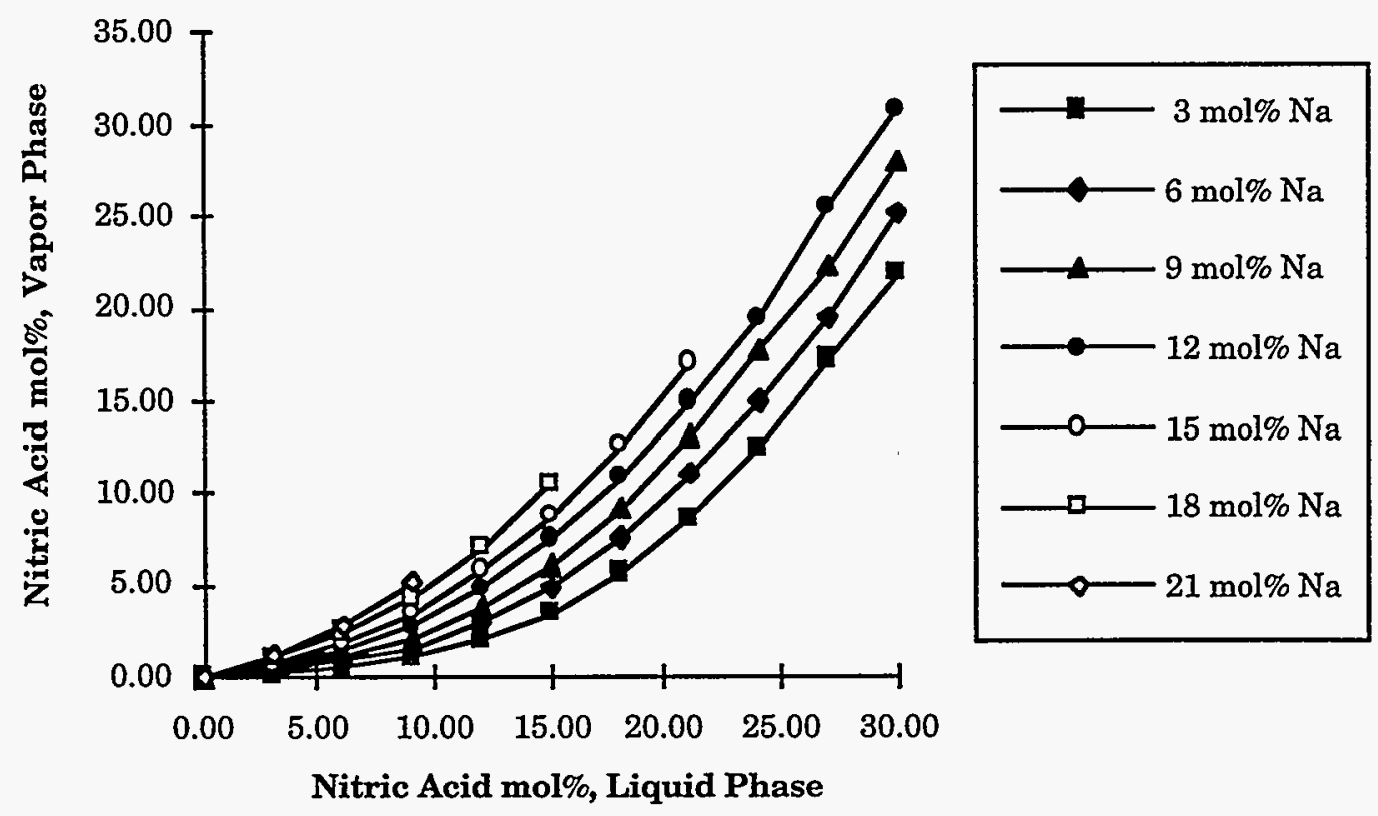

Fig. B-7. Concentration of Nitric Acid in the Vapor Phase as a Function of the Concentration in the Liquid Phase of Sodium Nitrate at $760 \mathrm{mmHg}$ 
Shneerson et al. [SHNEERSON] showed that the azeotropic composition (the point at which the liquid and vapor-phase concentrations are equal) of the nitric acid-water-salt system decreased as the concentration of magnesium nitrate or calcium nitrate increased. In other words, the azeotropic point occurred at lower concentrations of nitric acid in the liquid phase as the salt concentration increased. This behavior also occurs with aluminum nitrate (Fig. B-6). The diagonal line in Fig. B-6 represents equal compositions in the liquid and vapor phases. Thus, the points of intersection between this line and the curves from the data are azeotropes for that concentration of salt.

As mentioned earlier, the boiling point of the system increases with increasing salt concentration. This effect is illustrated in Fig. B-8 for sodium nitrate at $760 \mathrm{mmHg}$ [EFIMOV1974]. The data are listed in Table B-15.

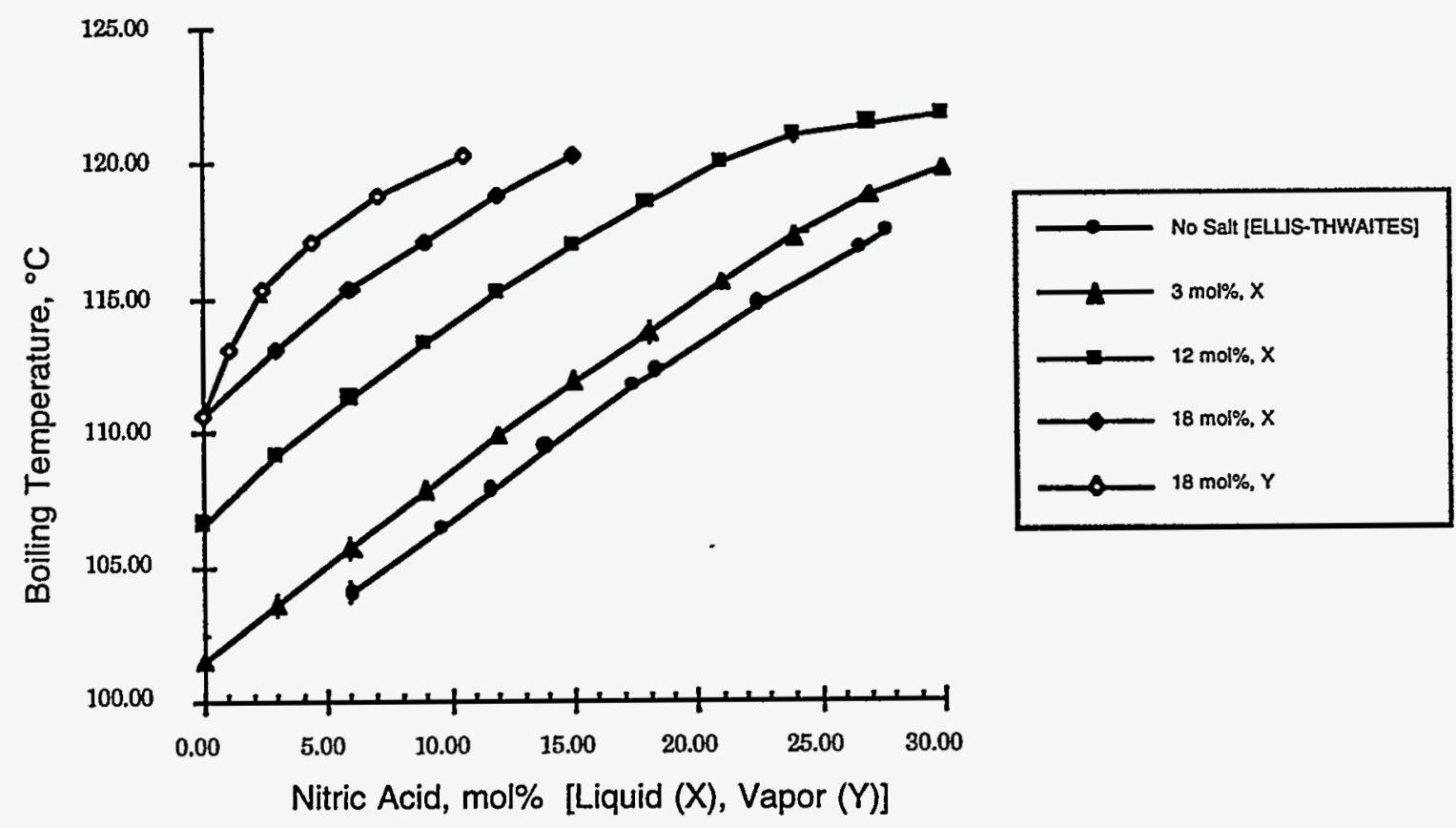

Fig. B-8. Boiling Temperature vs. Concentrations of Nitric Acid and Sodium Nitrate

\section{Pressure Effects}

The system pressure for nitric acid-water-nitrate salt systems affects both the concentration of nitric acid in the vapor phase and the system boiling point. According to Efimov et al. [EFIMOV-1970, EFIMOV-1973], when the nitric acid concentration in the vapor phase (y) was low, it decreased as the system pressure decreased. The region of low concentration was reported as $\mathrm{y}<15 \mathrm{~mol} \%$ in the $\mathrm{H}_{2} \mathrm{O}-\mathrm{HNO}_{3}-\mathrm{UO}_{2}\left(\mathrm{NO}_{3}\right)_{2}$ system and $\mathrm{y}<25 \mathrm{~mol} \%$ in the $\mathrm{H}_{2} \mathrm{O}-\mathrm{HNO}_{3}-\mathrm{Be}\left(\mathrm{NO}_{3}\right)_{2}$ and $\mathrm{H}_{2} \mathrm{O}-\mathrm{HNO}_{3}-\mathrm{Cu}\left(\mathrm{NO}_{3}\right)_{2}$ systems. They found the opposite effect for higher vapor concentrations, as illustrated in Fig. B-9 for the $\mathrm{H}_{2} \mathrm{O}-\mathrm{HNO}_{3}-\mathrm{UO}_{2}\left(\mathrm{NO}_{3}\right)_{2}$ system [EFIMOV-1970]. The data are listed in Table B-16.

The temperature at which a system will boil is affected by both the composition of the system and the system pressure. Decreasing the pressure of the system while maintaining a constant solution composition reduces the boiling point of the solution. An example of this is shown in Fig. B-10 for $3 \mathrm{~mol} \%$ sodium nitrate (using data from Table B-15) [EFIMOV-1974]. 


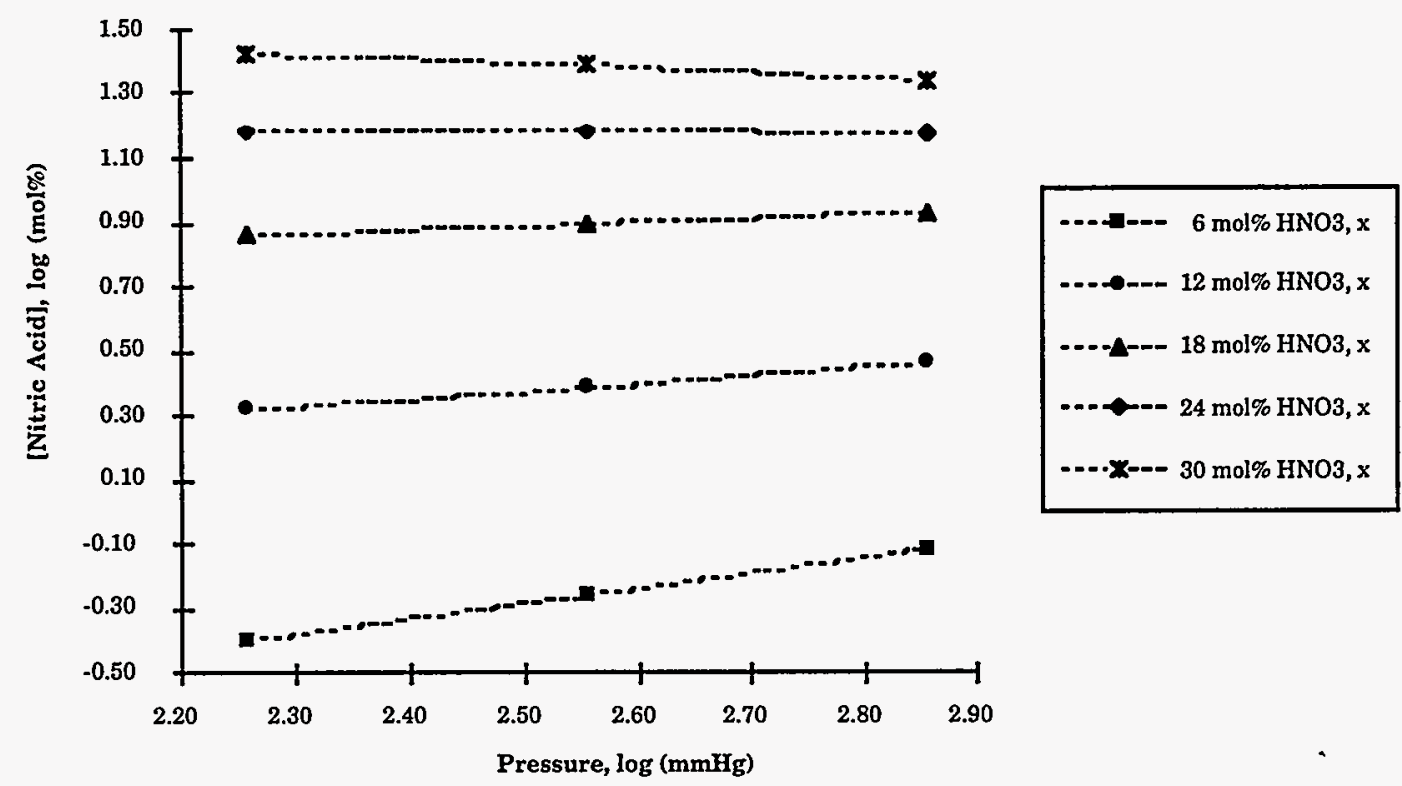

Fig B-9. Nitric Acid Concentration in the Vapor Phase [log (mol \%)] vs. System Pressure $[\log (\mathrm{mmHg})]$ for the $\mathrm{HNO}_{3}-\mathrm{H}_{2} \mathrm{O}-\mathrm{UO}_{2}\left(\mathrm{NO}_{3}\right)_{2}$ at a Constant Salt Concentration of $3 \mathrm{~mol} \%$

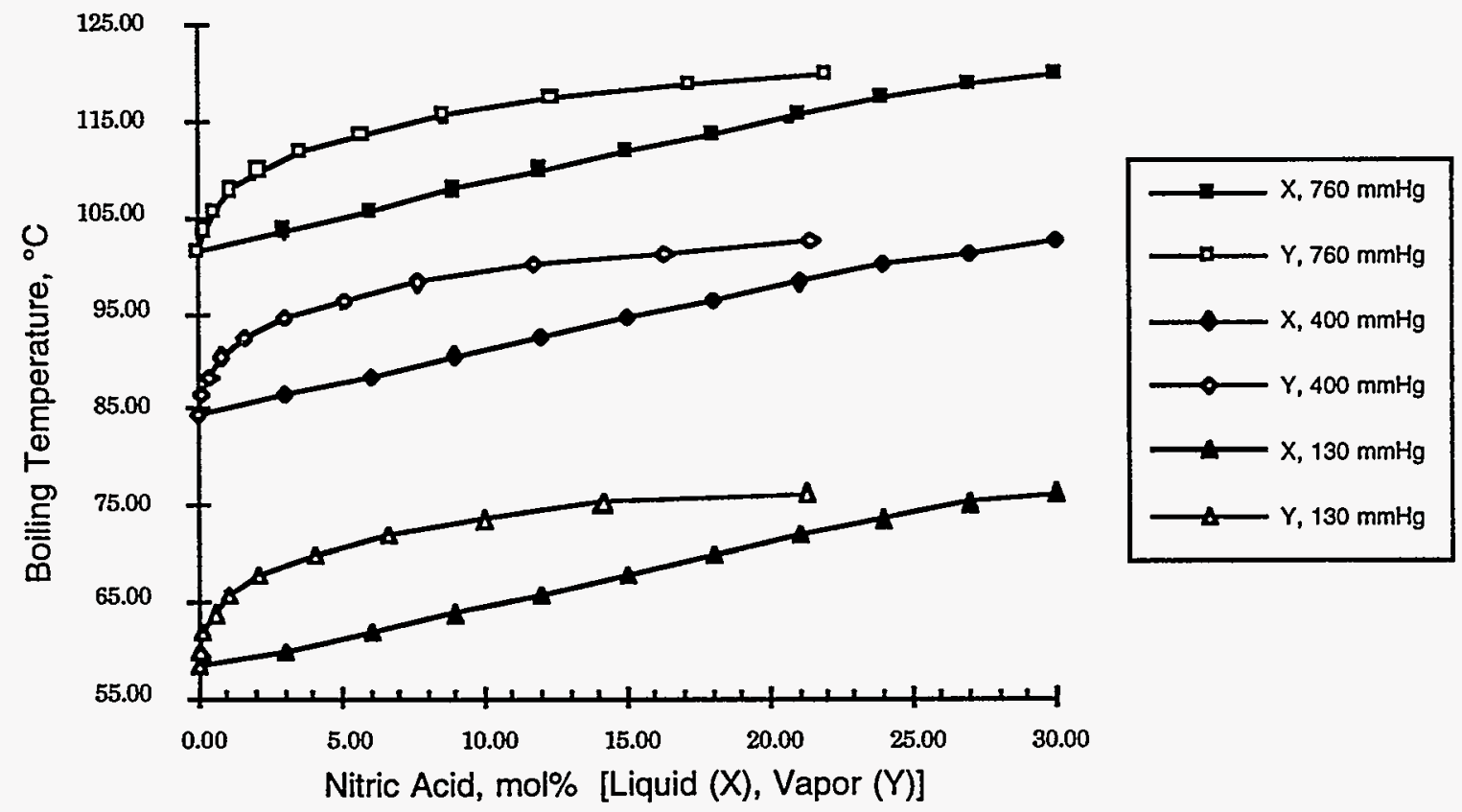

Fig. B-10. System Pressure vs. Boiling Temperature of the Nitric Acid-Water-3 mol\% Sodium Nitrate System 


\section{Multiple Salts Systems}

Since the evaporator will operate with solutions containing more than one salt, the effect of multiple salts on the nitric acid-water-salt system is important. Both Zhikharev et al. [ZHIKAREV] and Shneerson et al. [SHNEERSON] suggest that the presence of two or more salts is approximately additive. Zhikharev et al. studied ternary systems of $\mathrm{HNO}_{3}-\mathrm{H}_{2} \mathrm{O}-\mathrm{Fe}\left(\mathrm{NO}_{3}\right)_{3}$ and $\mathrm{HNO}_{3}-\mathrm{H}_{2} \mathrm{O}-\mathrm{Cu}\left(\mathrm{NO}_{3}\right)_{2}$. From the results of these systems they used Eq. B-2 to predict the acid concentration in the vapor phase for the system $\mathrm{HNO}_{3}-\mathrm{H}_{2} \mathrm{O}-\mathrm{Cu}\left(\mathrm{NO}_{3}\right)_{2}-\mathrm{Fe}\left(\mathrm{NO}_{3}\right)_{3}$.

$$
\log \frac{Y}{100-Y}=\sum_{i} \frac{C_{i}}{C_{S}} \log \frac{Y_{i}}{100-Y_{i}}
$$

where $Y=$ concentration of nitric acid in the vapor phase for the multicomponent system when $\mathrm{X}$ is constant

$Y_{i}=$ concentration of nitric acid in the vapor phase as a result of the $i^{\text {th }}$ salt from a ternary system

$\mathrm{C}_{\mathrm{i}}=$ concentration of the $\mathrm{i}^{\text {th }}$ salt

$\mathrm{C}_{\mathrm{S}}=$ total concentration of the salting-out agent

They found that the calculated results agreed well with experimental results for the four-component system. They concluded that Eq. B-2 could be used to predict, within experimental error, the nitric acid concentration in the vapor phase for systems containing multiple salts from ternary system data.

Additional vapor-liquid equilibrium data for nitric acid-water-nitrate salt systems at various pressures was collected during this literature search but was not presented in this report. These systems include $\mathrm{Be}, \mathrm{Ca}, \mathrm{Cr}, \mathrm{Cu}, \mathrm{Fe}, \mathrm{Fe}+\mathrm{Cu}, \mathrm{La}, \mathrm{La}+\mathrm{Mg}, \mathrm{Ni}$, and $\mathrm{UO}_{2}$ nitrate salts. Furthermore, for the $\mathrm{Al}$ and $\mathrm{Na}$ nitrate salt systems, additional data were collected for pressures not presented above. These data tables and plots are recorded in a laboratory notebook for future reference.

\section{Binary Sulfuric Acid-Water and Phosphoric Acid-Water Systems}

Many references were available for sulfuric acid-water systems. Most of them, however, discussed systems over a limited range of sulfuric acid concentrations. One paper by Tarasenkov [TARASENKOV] presented data for acid concentrations ranging from 10.02 to $83.28 \mathrm{wt} \%$ and temperatures from $0-100^{\circ} \mathrm{C}$. The data are presented in Table B-17. Some of these data, sufficient to show the trends in water vapor pressure as the solution temperature and compostion are changed, are plotted in Fig. B-11. Note that the partial pressure of sulfuric acid is extremely small, $0.5 \mathrm{mmHg}$ for $89.25 \%$ sulfuric acid at $183^{\circ} \mathrm{C}$.

Three trends are evident from the data. First, the vapor pressure of water decreases as acid concentration increases. Second, the vapor pressure of water increases with increasing temperature. Note that the temperature in Fig. B-11 decreases from left to right. Third, the 


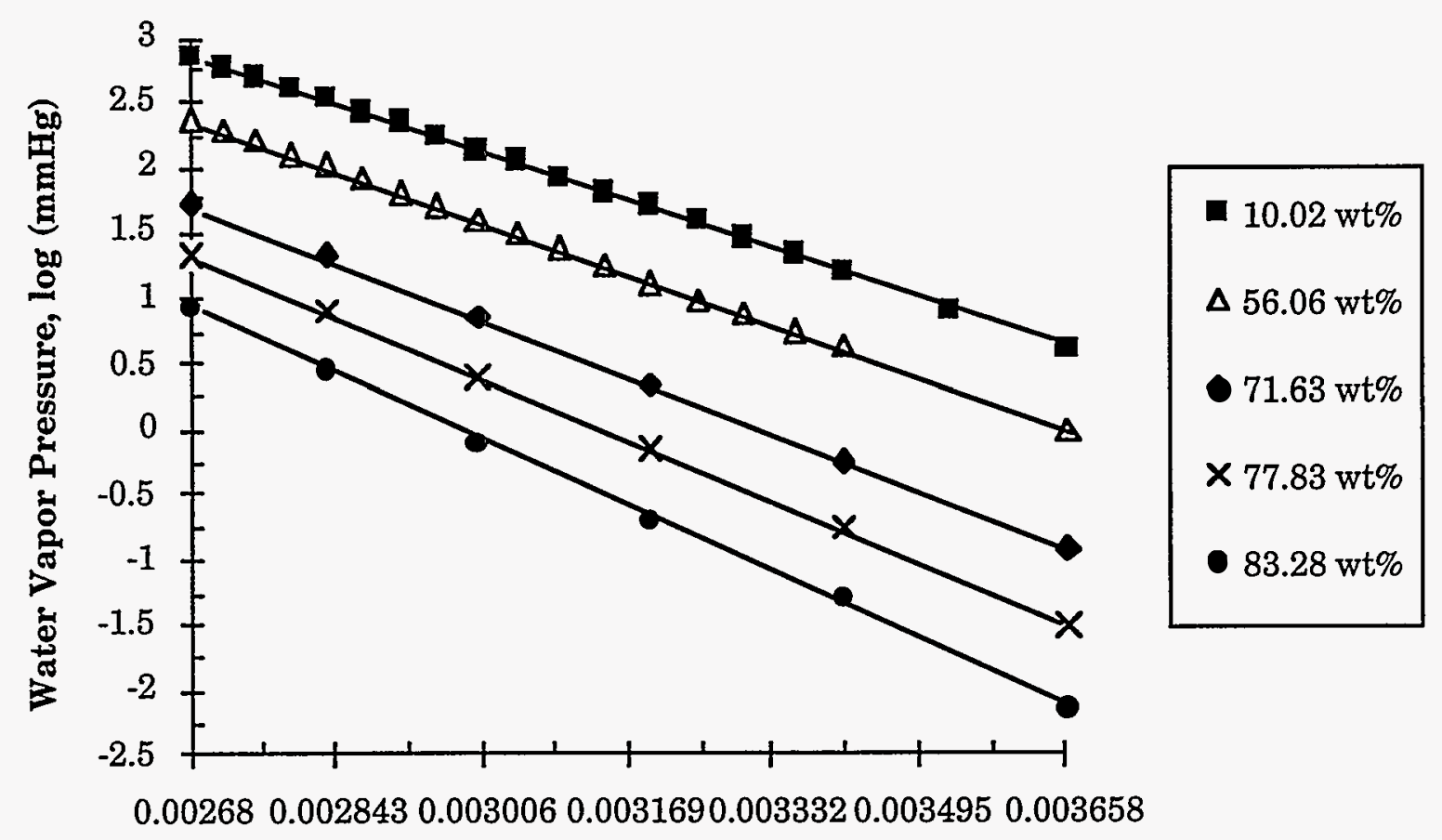

$(\mathbf{1} / \mathbf{K})$

Fig. B-11. Vapor Pressure of Water over Aqueous Sulfuric Acid Solutions vs. Absolute Temperature

relationship between the log of the vapor pressure and the inverse of the absolute temperature is nearly linear. This relationship may be expresses fairly accurately by the following equation:

$$
\log (\mathrm{p})=\mathrm{A}+\mathrm{B}(1 / \mathrm{T})
$$

For most acid concentrations the data were fit by minimizing the sum of the squares of the difference between the experimental vapor pressure and the calculated vapor pressure to obtain values for the constants $\mathrm{A}$ and $\mathrm{B}$. The constants obtained are given in Table B-18.

Only two references were available on phosphoric acid-water systems. Fontana [FONTANA] studied systems from $86.5 \%$ to almost $100 \%$ phosphoric acid. As was done for the sulfuric acid-water system, he showed a linear relationship between the log of the pressure and the inverse of the absolute temperature. This concentration range, however, is not likely to occur in the evaporator; therefore the data are not presented here. Elmore et al. [ELMORE] studied the activity of aqueous phosphoric acid systems at $25^{\circ} \mathrm{C}$ from 1 to 75 molal $\mathrm{H}_{3} \mathrm{PO}_{4}$. Sulfuric acid was used as a reference standard. The activity of water is plotted as a function of phosphoric acid concentration in Fig. B-12. The data are presented in Table B-19. As was noted for sulfuric acid systems, the activity of water decreases with increasing concentration of phosphoric acid for a constant temperature.

Because information is limited on phosphoric- and sulfuric-acid systems, it might be useful to study these systems further. 


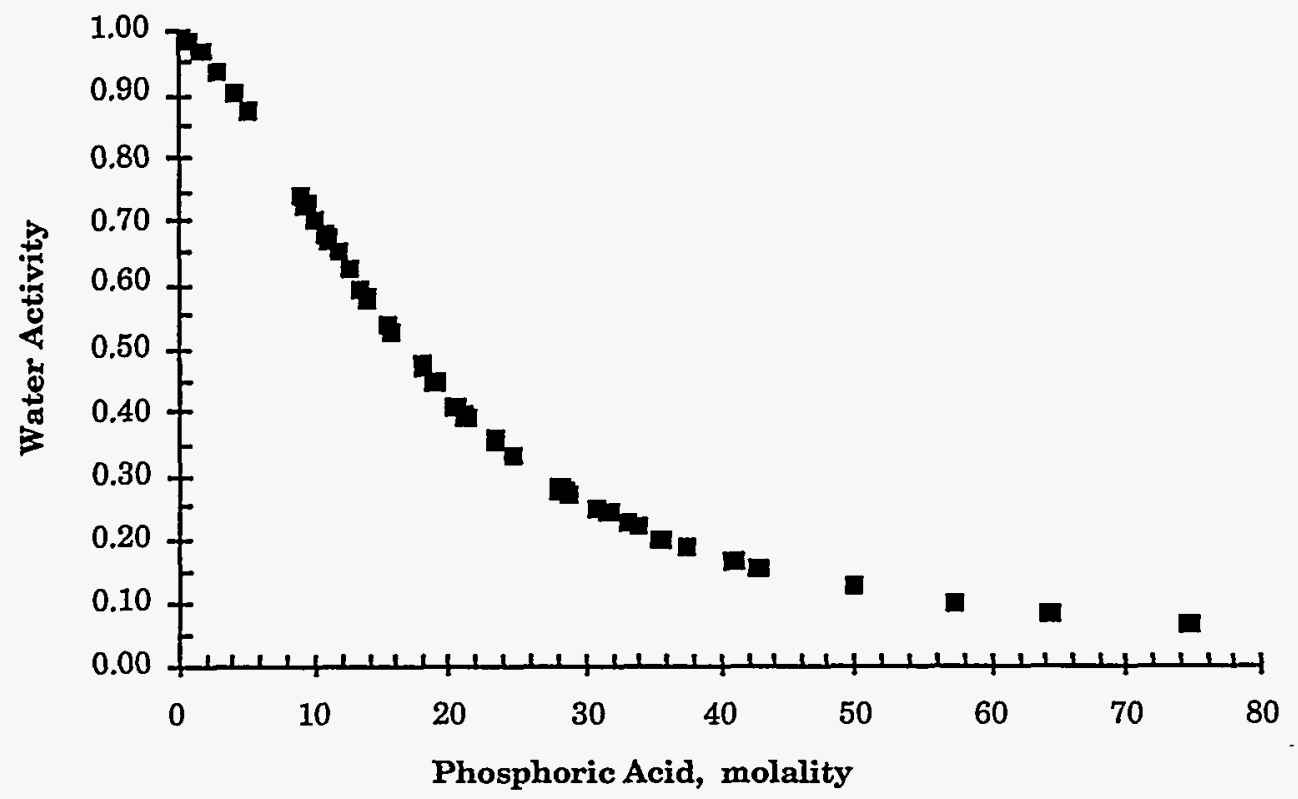

Fig. B-12. Activity of Water vs. Aqueous Phosphoric Acid Concentrations

\section{Multiple Acid Systems}

Information on systems containing nitric acid-water and some other acid, such as sulfuric, phosphoric or oxalic acid, was very limited. One paper by Flatt and Bonnet [FLATT], was obtained for the nitric acid-water-phosphoric acid system. This paper appears to have useful information and is being translated from French. Another paper by Berl et al. [BERL] discussed both the nitric acid-water-phosphoric acid and the nitric acid-water-sulfuric acid systems. It is written in German and was not translated. This paper contains a few figures but no data tables. Ellis and Thwaites [ELLIS] studied the nitric acid-water-sulfuric acid system, and Petrov et al. [PETROV] studied the nitric acid-water-phosphoric acid system (only the abstract is currently available for this paper). Both authors found that the presence of the second acid tended to salt out the nitric acid into the vapor phase. Ellis and Thwaites [ELLIS] also showed that the equilibrium temperature increased with increasing concentration of sulfuric acid. These phenomena are illustrated Fig. B-13 and Fig. B-14 using data from Ellis and Thwaites [ELLIS] for the nitric acid-sulfuric acid-water system. The data in is listed in Table B-20.

No information was available in the literature for the vapor-liquid equilibrium of nitric acid-water-oxalic acid or oxalic acid-water systems. 


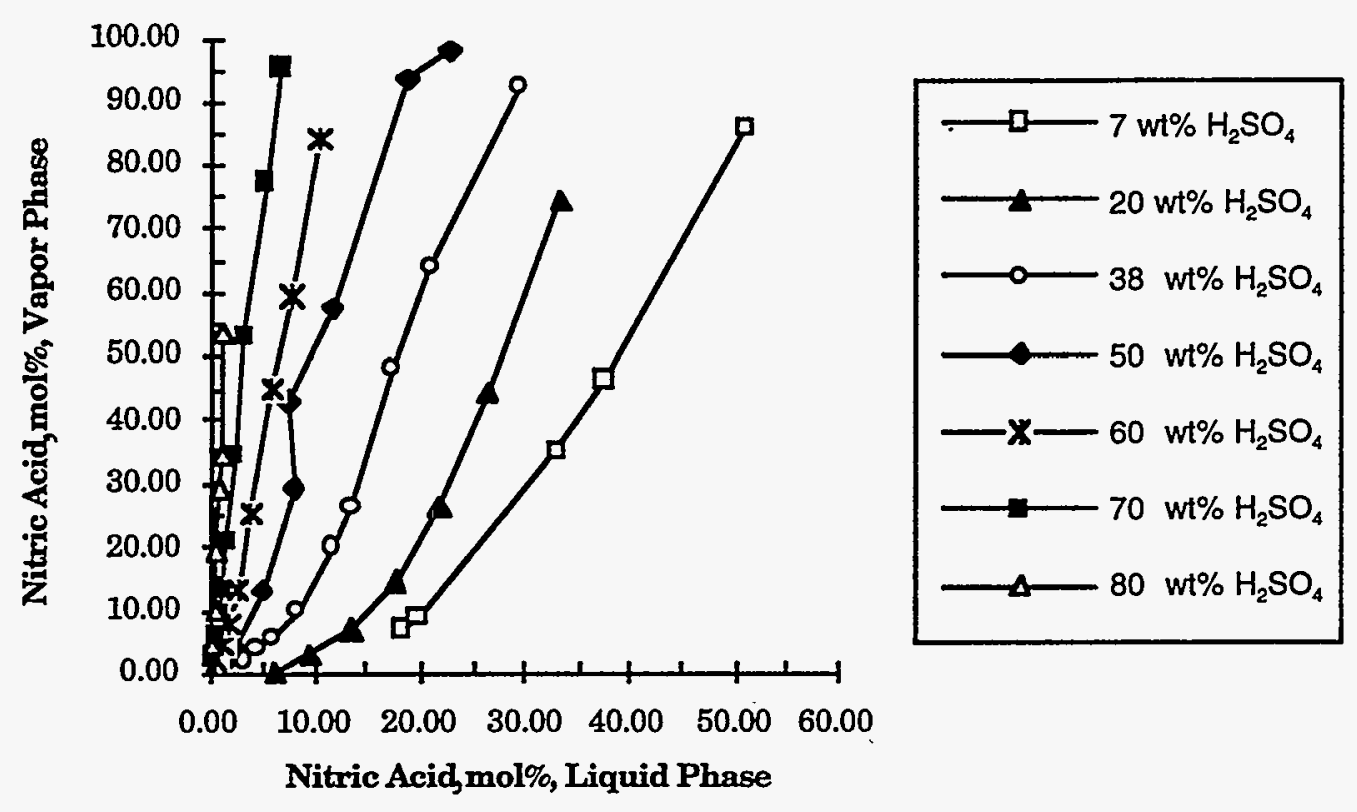

Fig. B-13. Concentration of Nitric Acid in the Vapor Phase above Solutions of Nitric Acid-Water-Sulfuric Acid at $760 \mathrm{mmHg}$

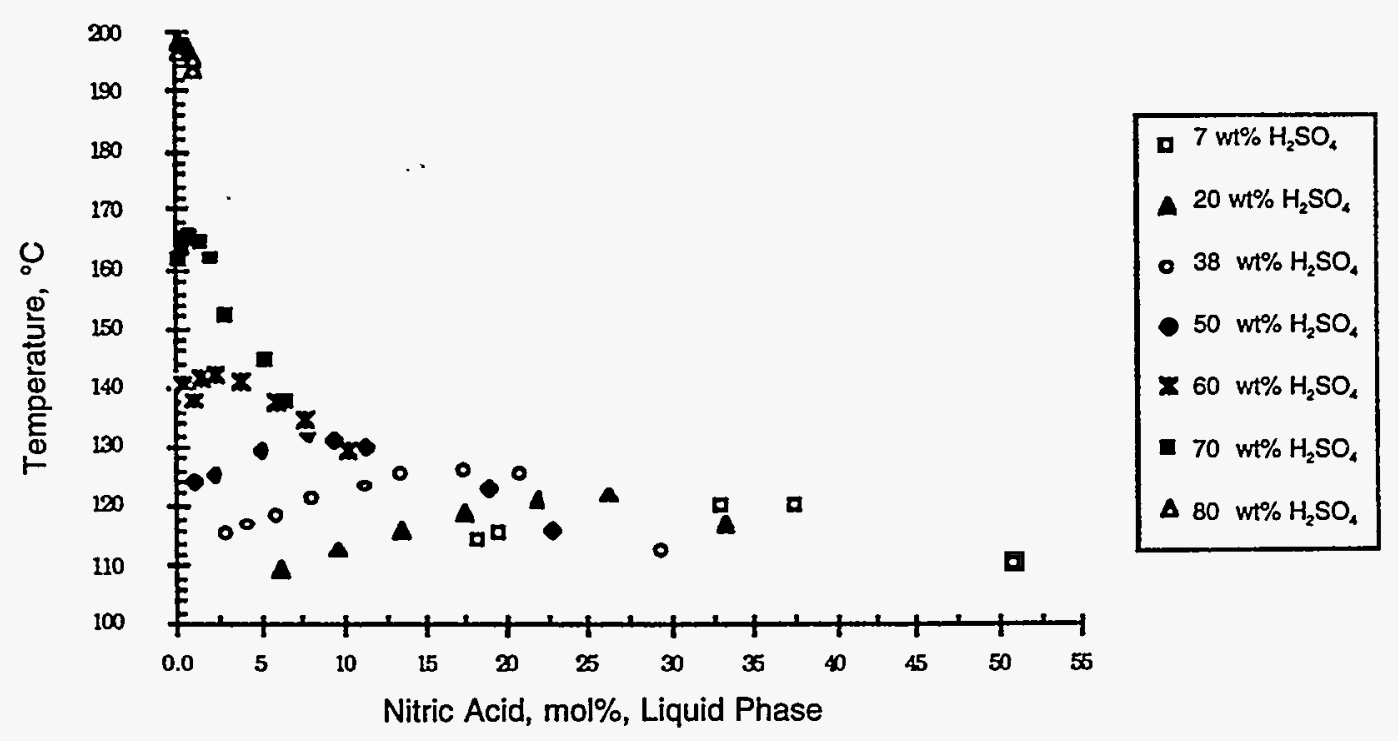

Fig. B-14. Temperature vs. Nitric Acid in the Liquid Phase for Nitric Acid-Water-Sulfuric Acid Systems at $760 \mathrm{mmHg}$ 
Table B-3. Comparison of Data for Binary $\mathrm{HNO}_{3}-\mathrm{H}_{2} \mathrm{O}$ Systems at $760 \mathrm{mmHg}$ from Ellis and Thwaites ${ }^{\mathrm{a}}$

\begin{tabular}{ccc}
\hline \multicolumn{2}{c}{$\mathrm{HNO}_{3}, \mathrm{~mol} \%$} & \\
\cline { 1 - 2 } Liquid & Vapor & Temp., ${ }^{\circ} \mathrm{C}$ \\
\hline 6.10 & 0.36 & 104.0 \\
9.60 & 0.95 & 106.4 \\
11.70 & 1.50 & 107.8 \\
13.90 & 2.11 & 109.4 \\
17.50 & 4.23 & 111.8 \\
18.30 & 5.10 & 112.3 \\
22.50 & 8.95 & 114.8 \\
26.60 & 13.60 & 116.9 \\
27.70 & 15.99 & 117.5 \\
34.10 & 25.90 & 119.4 \\
37.40 & 36.50 & 119.9 \\
38.32 & 37.45 & 120.1 \\
48.50 & 73.00 & 116.1 \\
52.10 & 81.08 & 113.4 \\
54.70 & 85.00 & 110.8 \\
65.10 & 94.20 & 102.9 \\
71.90 & 97.20 & 96.1 \\
76.50 & 98.75 & 92.0 \\
81.60 & 99.30 & 88.4 \\
100.0 & 100.00 & 83.4 \\
\hline${ }^{a}[$ ELLIS] & &
\end{tabular}

Table B-4. Comparison of Data for Binary $\mathrm{HNO}_{3}-\mathrm{H}_{2} \mathrm{O}$ Systems at $760 \mathrm{mmHg}$ from Boublik et al. ${ }^{\mathrm{a}}$

\begin{tabular}{ccc}
\hline \multicolumn{2}{c}{$\mathrm{HNO}_{3}$, mol\% } & \\
\cline { 1 - 2 } Liquid & Vapor & Temp., ${ }^{\circ} \mathrm{C}$ \\
\hline 8.88 & 8.00 & 106.50 \\
9.00 & 1.10 & 106.50 \\
11.70 & 1.70 & 108.50 \\
14.50 & 2.60 & 110.70 \\
25.80 & 13.80 & 117.80 \\
35.50 & 32.40 & 120.60 \\
36.10 & 34.00 & 120.60 \\
39.80 & 44.00 & 120.30 \\
40.30 & 44.50 & 120.10 \\
51.60 & 70.50 & 113.50 \\
66.80 & 89.30 & 98.20 \\
69.80 & 91.20 & 96.00 \\
85.80 & 97.80 & 85.80 \\
\hline
\end{tabular}

a[HALA-1960] 
Table B-5. Comparison of Data for Binary $\mathrm{HNO}_{3}-\mathrm{H}_{2} \mathrm{O}$ Systems at $760 \mathrm{mmHg}$ from Prosek ${ }^{a}$

\begin{tabular}{ccc}
\hline \multicolumn{2}{c}{$\mathrm{HNO}_{3}, \mathrm{~mol} \%$} & \\
\cline { 1 - 2 } Liquid & Vapor & Temp., ${ }^{\circ} \mathrm{C}$ \\
\hline 17.85 & 4.39 & 111.15 \\
23.91 & 10.27 & 114.80 \\
34.84 & 29.85 & 119.85 \\
39.95 & 43.00 & 119.35 \\
41.83 & 47.46 & 119.05 \\
47.08 & 61.19 & 117.20 \\
47.61 & 62.61 & 117.20 \\
49.51 & 67.60 & 116.10 \\
\hline
\end{tabular}

a[HALA-1968] 
Table B-6. Comparison of Data for Binary $\mathrm{HNO}_{3}-\mathrm{H}_{2} \mathrm{O}$ Systems at $760 \mathrm{mmHg}$ from Potier and Alger ${ }^{a}$

\begin{tabular}{ccc}
\multicolumn{2}{c}{$\mathrm{HNO}_{3}, \mathrm{~mol} \%$} & \\
\cline { 1 - 2 } Liquid & Vapor & Temp., ${ }^{\circ} \mathrm{C}$ \\
\hline 6.70 & 0.25 & 104.00 \\
7.20 & 0.25 & 104.50 \\
10.20 & 1.03 & 106.50 \\
10.20 & 1.05 & 106.70 \\
11.00 & 1.20 & 107.00 \\
13.50 & 2.00 & 108.50 \\
14.10 & 2.30 & 109.50 \\
16.20 & 3.50 & 110.50 \\
18.10 & 4.20 & 111.50 \\
18.10 & 4.20 & 112.00 \\
21.70 & 8.20 & 114.50 \\
23.30 & 9.60 & 115.50 \\
28.20 & 16.50 & 117.50 \\
30.00 & 19.10 & 118.00 \\
33.70 & 21.10 & 119.00 \\
34.80 & 29.70 & 119.20 \\
45.00 & 56.40 & 118.50 \\
47.40 & 65.10 & 117.00 \\
51.50 & 76.20 & 115.00 \\
51.50 & 73.60 & 114.90 \\
53.00 & 76.40 & 113.00 \\
54.00 & 76.80 & 112.60 \\
55.70 & 85.70 & 111.50 \\
57.40 & 86.40 & 108.80 \\
60.60 & 93.60 & 106.00 \\
64.90 & 94.50 & 102.00 \\
70.00 & 96.00 & 97.50 \\
72.30 & 98.40 & 95.80 \\
73.80 & 98.60 & 95.50 \\
75.50 & 98.30 & 92.00 \\
80.20 & 98.30 & 91.00 \\
85.30 & 98.40 & 87.20 \\
87.80 & 98.80 & 86.90 \\
99.10 & 99.70 & 82.80 \\
\hline
\end{tabular}

a[HALA-1958] 
Table B-7. Data for Nitric Acid-Water System at a Pressure of $50 \mathrm{mmHg}^{\mathrm{a}}$

\begin{tabular}{ccc}
\hline \multicolumn{2}{c}{$\mathrm{HNO}_{3}, \mathrm{~mol} \%$} & \\
\cline { 1 - 2 } Liquid & Vapor & Temp., ${ }^{\circ} \mathrm{C}$ \\
\hline 9.30 & 0.60 & 43.00 \\
15.30 & 1.00 & 48.20 \\
24.00 & 9.00 & 55.00 \\
28.30 & 16.50 & 56.90 \\
35.30 & 34.50 & 57.80 \\
35.70 & 35.80 & 57.90 \\
38.50 & 43.90 & 57.60 \\
39.20 & 45.80 & 57.10 \\
54.60 & 79.50 & 50.40 \\
55.10 & 80.40 & 50.20 \\
57.60 & 84.80 & 47.40 \\
66.40 & 92.30 & 38.50 \\
68.10 & 91.90 & 36.60 \\
71.30 & 94.10 & 32.60 \\
72.70 & 95.00 & 32.50 \\
88.70 & 99.00 & 24.60 \\
\hline
\end{tabular}

a[HALA-1960]

Table B-8. Data for Nitric Acid-Water System at a Pressure of $100 \mathrm{mmHg}^{\mathrm{a}}$

\begin{tabular}{ccc}
\hline \multicolumn{2}{c}{$\mathrm{HNO}_{3}, \mathrm{~mol} \%$} & \\
\cline { 1 - 2 } Liquid & Vapor & Temp., ${ }^{\circ} \mathrm{C}$ \\
\hline 14.90 & 1.20 & 61.60 \\
21.90 & 5.40 & 65.60 \\
25.00 & 10.60 & 68.10 \\
31.00 & 22.40 & 71.60 \\
35.40 & 34.30 & 72.60 \\
38.90 & 44.30 & 71.70 \\
39.80 & 46.30 & 71.50 \\
43.30 & 57.60 & 70.10 \\
55.20 & 81.70 & 61.90 \\
62.90 & 88.10 & 55.60 \\
65.40 & 90.40 & 54.00 \\
68.30 & 92.60 & 50.80 \\
\hline
\end{tabular}

a[HALA-1960] 
Table B-9. Data for Nitric Acid-Water System at a Pressure of $200 \mathrm{mmHg}^{\mathrm{a}}$

\begin{tabular}{ccc}
\hline \multicolumn{2}{c}{$\mathrm{HNO}_{3}$, mol\% } & \\
\cline { 1 - 2 } Liquid & Vapor & Temp., ${ }^{\circ} \mathrm{C}$ \\
\hline 8.50 & 1.00 & 71.70 \\
13.20 & 1.10 & 75.40 \\
14.40 & 1.50 & 77.20 \\
19.20 & 4.00 & 79.50 \\
28.40 & 17.10 & 84.80 \\
35.60 & 34.10 & 86.50 \\
39.70 & 47.00 & 86.30 \\
43.20 & 55.00 & 85.10 \\
55.80 & 79.90 & 73.40 \\
65.30 & 89.30 & 64.60 \\
68.60 & 93.10 & 61.90 \\
71.60 & 94.00 & 58.20 \\
93.30 & 98.60 & 49.80 \\
\hline
\end{tabular}

Table B-10. Data for Nitric Acid-Water System at a Pressure of $400 \mathrm{mmHg}^{\mathrm{a}}$

\begin{tabular}{ccc}
\hline \multicolumn{2}{c}{$\mathrm{HNO}_{3}, \mathrm{~mol} \%$} & \\
\cline { 1 - 2 } Liquid & Vapor & Temp., ${ }^{\circ} \mathrm{C}$ \\
\hline 13.50 & 1.60 & 91.90 \\
18.10 & 4.50 & 96.00 \\
29.60 & 20.50 & 102.40 \\
35.70 & 32.10 & 103.20 \\
39.80 & 45.50 & 102.80 \\
43.50 & 54.40 & 101.60 \\
53.30 & 73.90 & 94.10 \\
53.70 & 74.90 & 94.00 \\
54.60 & 77.00 & 92.70 \\
71.80 & 93.10 & 78.50 \\
88.00 & 98.80 & 68.50 \\
88.90 & 98.80 & 67.80 \\
\hline a[HALA-1960] & &
\end{tabular}

a[HALA-1960] 
Table B-11. Data for Nitric Acid-Water System at a Pressure of $450 \mathrm{mmHg}^{\mathrm{a}}$

\begin{tabular}{ccc}
\hline \multicolumn{2}{c}{$\mathrm{HNO}_{3}, \mathrm{~mol} \%$} & \\
\cline { 1 - 2 } Liquid & Vapor & Temp., ${ }^{\circ} \mathrm{C}$ \\
\hline 5.20 & 0.00 & 88.60 \\
6.90 & 0.01 & 89.70 \\
8.90 & 0.22 & 92.00 \\
9.60 & 0.24 & 92.40 \\
18.10 & 3.20 & 100.00 \\
24.10 & 8.10 & 102.00 \\
30.00 & 11.40 & 103.80 \\
30.20 & 8.70 & 104.40 \\
32.20 & 23.80 & 104.70 \\
31.60 & 21.60 & 105.00 \\
32.20 & 24.90 & 105.20 \\
34.10 & 27.10 & 105.30 \\
36.80 & 36.70 & 106.00 \\
45.70 & 60.70 & 104.00 \\
49.80 & 72.60 & 101.00 \\
53.70 & 82.30 & 97.50 \\
63.00 & 88.60 & 91.50 \\
72.50 & 96.30 & 81.90 \\
75.90 & 96.10 & 79.50 \\
82.40 & 96.30 & 74.60 \\
87.50 & 97.00 & 73.10 \\
90.10 & 96.80 & 72.20 \\
91.40 & 97.90 & 71.40 \\
93.80 & 96.75 & 70.60 \\
96.10 & 97.40 & 70.00 \\
\hline
\end{tabular}

${ }^{\mathrm{a}}$ [HALA-1958] 
Table B-12. Data for Nitric Acid-Water System at a Pressure of $600 \mathrm{mmHg}^{\mathrm{a}}$

\begin{tabular}{ccc}
\hline \multicolumn{2}{c}{$\mathrm{HNO}_{3}$, mol\% } & \\
\cline { 1 - 2 } Liquid & Vapor & Temp., ${ }^{\circ} \mathrm{C}$ \\
\hline 1.70 & 0.01 & 94.20 \\
2.90 & 0.08 & 96.00 \\
5.10 & 0.10 & 96.90 \\
4.20 & 0.07 & 97.00 \\
4.30 & 0.08 & 97.10 \\
4.80 & 0.08 & 97.30 \\
7.90 & 0.29 & 98.60 \\
7.20 & 0.20 & 99.20 \\
8.40 & 0.30 & 100.00 \\
10.80 & 1.05 & 102.00 \\
13.90 & 1.80 & 103.50 \\
16.40 & 2.90 & 105.00 \\
18.70 & 4.00 & 106.20 \\
18.70 & 5.90 & 108.20 \\
25.90 & 9.50 & 110.80 \\
33.80 & 26.70 & 113.50 \\
36.90 & 36.80 & 113.70 \\
39.20 & 42.30 & 113.60 \\
43.90 & 56.30 & 112.80 \\
53.30 & 72.70 & 108.00 \\
52.80 & 74.20 & 107.90 \\
54.60 & 82.30 & 105.00 \\
58.90 & 91.30 & 102.10 \\
60.00 & 94.50 & 99.10 \\
63.30 & 92.90 & 97.00 \\
70.60 & 98.00 & 93.30 \\
69.10 & 96.00 & 91.70 \\
72.80 & 98.00 & 99.20 \\
72.20 & 98.40 & 87.80 \\
89.10 & 98.40 & 79.50 \\
96.10 & 99.80 & 76.80 \\
\hline${ }^{2}[\mathrm{HALA}-1958]$ & & \\
& &
\end{tabular}

a[HALA-1958] 
Table B-13. Comparison of Salting-Out Capacity of $6 \mathrm{~mol} \% \mathrm{La}$, Ni, and $\mathrm{Na}$ at $400 \mathrm{mmHg}$

\begin{tabular}{cccccc}
\hline \multicolumn{2}{c}{$\mathrm{La}_{2}$} & \multicolumn{2}{c}{$\left.\left.\mathrm{Ni}_{3}\right)_{3}{ }^{\mathrm{a}} \mathrm{NO}_{3}\right)_{2}{ }^{\mathrm{a}}$} & \multicolumn{2}{c}{$\mathrm{NaNO}_{3}{ }^{\mathrm{b}}$} \\
\hline \multicolumn{2}{c}{$\mathrm{HNO}_{3}, \mathrm{~mol} \%$} & \multicolumn{2}{c}{$\mathrm{HNO}_{3}, \mathrm{~mol} \%$} & \multicolumn{2}{c}{$\mathrm{HNO}_{3}, \mathrm{~mol}^{2}$} \\
\hline Liquid & Vapor & Liquid & Vapor & Liquid & Vapor \\
\hline 6.00 & 2.59 & 6.00 & 3.50 & 0.00 & 0.00 \\
9.00 & 5.03 & 15.00 & 16.11 & 3.00 & 0.22 \\
15.00 & 15.25 & 24.00 & 35.30 & 6.00 & 0.62 \\
24.00 & 40.83 & & & 9.00 & 1.23 \\
& & & & 12.00 & 2.34 \\
& & & & 15.00 & 4.18 \\
& & & & 18.00 & 6.82 \\
& & & & 21.00 & 10.28 \\
& & & & 24.00 & 14.28 \\
& & & & 30.00 & 19.11 \\
& & & & & \\
\hline
\end{tabular}

Table B-14. Aluminum Nitrate Data at $130 \mathrm{mmHg}^{\mathrm{a}}$

\begin{tabular}{ccc}
\hline & \multicolumn{2}{c}{$\mathrm{HNO}_{3}, \mathrm{~mol} \%$} \\
\cline { 2 - 3 } Salt, wt\% & Liquid & Vapor \\
\hline 10 & 3.08 & 0.11 \\
& 6.67 & 0.40 \\
& 10.91 & 1.13 \\
& 16.00 & 4.57 \\
20 & 22.23 & 14.19 \\
& 3.08 & 0.20 \\
& 6.67 & 0.91 \\
& 10.91 & 3.39 \\
& 16.00 & 11.24 \\
30 & 22.23 & 27.13 \\
& 3.08 & 0.61 \\
& 6.67 & 2.60 \\
40 & 10.91 & 8.84 \\
& 16.00 & 20.45 \\
& 3.08 & 2.48 \\
50 & 6.67 & 8.30 \\
& 10.91 & 23.12 \\
& 3.08 & 9.47 \\
a[EFIMOV-1975] & 6.67 & 24.84 \\
\hline
\end{tabular}


Table B-15. Sodium Nitrate Data at $760 \mathrm{mmHg}^{\mathrm{a}}$

\begin{tabular}{|c|c|c|c|}
\hline \multicolumn{4}{|c|}{$\mathrm{HNO}_{3}, \mathrm{~mol} \%$} \\
\hline Salt, mol\% & Liquid & Vapor & Temp, ${ }^{\circ} \mathrm{C}$ \\
\hline \multirow[t]{11}{*}{3.00} & 0.00 & 0.00 & 101.40 \\
\hline & 3.00 & 0.21 & 103.60 \\
\hline & 6.00 & 0.54 & 105.70 \\
\hline & 9.00 & 1.13 & 107.80 \\
\hline & 12.00 & 2.17 & 109.90 \\
\hline & 15.00 & 3.60 & 111.90 \\
\hline & 18.00 & 5.80 & 113.70 \\
\hline & 21.00 & 8.63 & 115.60 \\
\hline & 24.00 & 12.42 & 117.30 \\
\hline & 27.00 & 17.23 & 118.80 \\
\hline & 30.00 & 22.00 & 119.80 \\
\hline \multirow[t]{11}{*}{6.00} & 0.00 & 0.00 & 103.10 \\
\hline & 3.00 & 0.33 & 105.40 \\
\hline & 6.00 & 0.85 & 107.60 \\
\hline & 9.00 & 1.60 & 109.70 \\
\hline & 12.00 & 2.93 & 111.70 \\
\hline & 15.00 & 4.91 & 113.50 \\
\hline & 18.00 & 7.70 & 115.30 \\
\hline & 21.00 & 11.10 & 117.00 \\
\hline & 24.00 & 15.03 & 118.60 \\
\hline & 27.00 & 19.54 & 120.00 \\
\hline & 30.00 & 25.30 & 120.50 \\
\hline \multirow[t]{11}{*}{9.00} & 0.00 & 0.00 & 104.80 \\
\hline & 3.00 & 0.50 & 107.20 \\
\hline & 6.00 & 1.21 & 109.40 \\
\hline & 9.00 & 2.15 & 111.50 \\
\hline & 12.00 & 3.79 & 113.40 \\
\hline & 15.00 & 6.16 & 115.40 \\
\hline & 18.00 & 9.25 & 117.00 \\
\hline & 21.00 & 13.15 & 118.60 \\
\hline & 24.00 & 17.76 & 120.00 \\
\hline & 27.00 & 22.23 & 120.70 \\
\hline & 30.00 & 28.00 & 121.20 \\
\hline \multirow[t]{11}{*}{12.00} & 0.00 & 0.00 & 106.60 \\
\hline & 3.00 & 0.67 & 109.20 \\
\hline & 6.00 & 1.55 & 111.30 \\
\hline & 9.00 & 2.88 & 113.40 \\
\hline & 12.00 & 4.85 & 115.20 \\
\hline & 15.00 & 7.57 & 116.90 \\
\hline & 18.00 & 10.95 & 118.50 \\
\hline & 21.00 & 15.10 & 120.00 \\
\hline & 24.00 & 19.53 & 121.00 \\
\hline & 27.00 & 25.61 & 121.50 \\
\hline & 30.00 & 30.86 & 121.80 \\
\hline \multirow[t]{6}{*}{15.00} & 0.00 & 0.00 & 108.50 \\
\hline & 3.00 & 0.81 & 111.10 \\
\hline & 6.00 & 1.92 & 113.30 \\
\hline & 9.00 & 3.51 & 115.20 \\
\hline & 12.00 & 5.85 & 116.90 \\
\hline & 15.00 & 8.90 & 118.60 \\
\hline
\end{tabular}


Table B-15. (contd)

\begin{tabular}{cccc}
\hline \multicolumn{4}{c}{$\mathrm{HNO}_{3}, \mathrm{~mol} \%$} \\
\hline Salt, mol\% & Liquid & Vapor & Temp, ${ }^{\circ} \mathrm{C}$ \\
\hline \multirow{4}{*}{18.00} & 18.00 & 12.65 & 120.00 \\
& 21.00 & 17.20 & 121.50 \\
& 0.00 & 0.00 & 110.60 \\
& 3.00 & 1.02 & 113.10 \\
& 6.00 & 2.40 & 115.30 \\
& 9.00 & 4.40 & 117.10 \\
21.00 & 12.00 & 7.15 & 118.80 \\
& 15.00 & 10.60 & 120.30 \\
& 0.00 & 0.00 & 112.70 \\
& 3.00 & 1.23 & 115.00 \\
& 6.00 & 2.90 & 117.20 \\
& 9.00 & 5.18 & 119.00 \\
\hline
\end{tabular}

a[EFIMOV-1974]

Table B-16. Vapor-Liquid Equilibrium Data for $\mathrm{HNO}_{3}-\mathrm{H}_{2} \mathrm{O}-\mathrm{UO}_{2}\left(\mathrm{NO}_{3}\right)_{2}$ System at Three Pressures for a Constant Salt Concentration of $3 \mathrm{~mol} \%^{\mathrm{a}}$

\begin{tabular}{ccccccc}
\hline & \multicolumn{6}{c}{ System Pressure, mmHg } \\
\cline { 2 - 7 } $\mathrm{HNO}_{3}, \mathrm{~mol} \%$ & $\mathrm{y}$ & $\log \mathrm{y}$ & $\mathrm{y}$ & $\log \mathrm{y}$ & $\mathrm{y}$ & $\log \mathrm{y}$ \\
\cline { 2 - 7 } & 0.40 & -0.40 & 0.55 & -0.26 & 0.77 & -0.11 \\
6 & 2.10 & 0.32 & 2.42 & 0.38 & 2.91 & 0.46 \\
12 & 7.32 & 0.86 & 7.86 & 0.90 & 8.51 & 0.93 \\
18 & 15.11 & 1.18 & 15.24 & 1.18 & 14.94 & 1.17 \\
24 & 26.38 & 1.42 & 24.36 & 1.39 & 21.98 & 1.34 \\
30 & & & & & &
\end{tabular}

a[EFIMOV-1970] 
Table B-17. Vapor Pressure above Aqueous Sulfuric Acid Solutions vs. Temperature and wt\% Sulfuric Acida

\begin{tabular}{|c|c|c|c|c|c|c|c|c|c|c|c|c|c|}
\hline \multirow{2}{*}{$\begin{array}{c}\text { Temp., } \\
{ }^{\circ}\end{array}$} & \multirow{2}{*}{$\begin{array}{c}1 / \mathrm{T} \\
(1 / \mathrm{K})\end{array}$} & \multicolumn{2}{|c|}{$10.02 \mathrm{wt} \%$} & \multicolumn{2}{|c|}{$20.4 \mathrm{wt} \%$} & \multicolumn{2}{|c|}{29.84 wt\% } & \multicolumn{2}{|c|}{34.74 wt\% } & \multicolumn{2}{|c|}{$39.90 \mathrm{wt} \%$} & \multicolumn{2}{|c|}{$48.44 \mathrm{wt} \%$} \\
\hline & & $\stackrel{p}{\mathrm{~m} \dot{\mathrm{m} g}}$ & $\log p$ & $\underset{\mathrm{mmHg}}{\mathrm{p}}$ & $\log p$ & $\begin{array}{c}\mathrm{p}, \\
\mathrm{mmHg}\end{array}$ & $\log p$ & $\underset{\mathrm{mmHg}}{\mathrm{m}}$ & $\log p$ & $\underset{\mathrm{mmHg}}{\mathrm{p}}$ & $\log p$ & $\underset{\mathrm{mm} H g}{\mathbf{p}}$ & $\log p$ \\
\hline 0 & 0.00366 & 4.08 & 0.6107 & 3.4 & 0.5340 & 2.9 & 0.4639 & 3.05 & 0.4843 & 1.8 & 0.2529 & 1.4 & 0.1584 \\
\hline 10 & 0.00353 & 8.17 & 0.9122 & 7.2 & 0.8591 & 6.1 & 0.7825 & & & 4.1 & 0.6096 & 3.0 & 0.4742 \\
\hline 20 & 0.00341 & 15.82 & 1.1992 & 15.3 & 1.1853 & 12.7 & 1.1048 & 10.99 & 1.0410 & 7.6 & 0.8808 & 7.0 & 0.8451 \\
\hline 25 & 0.00336 & 21.80 & 1.3385 & 20.8 & 1.3181 & 17.4 & 1.2405 & & & 10.9 & 1.0374 & 9.5 & 0.9791 \\
\hline 30 & 0.00330 & 28.60 & 1.4564 & 27.1 & 1.4330 & 21.9 & 1.3404 & & & 15.2 & 1.1810 & 12.3 & 1.0906 \\
\hline 35 & 0.00325 & 38.80 & 1.5888 & 37.3 & 1.5717 & 31.3 & 1.4955 & & & 21.5 & 1.3324 & 16.8 & 1.2251 \\
\hline 40 & 0.00319 & 50.30 & 1.7016 & 47.4 & 1.6758 & 39.9 & 1.6010 & 36.30 & 1.5599 & 29.8 & 1.4742 & 21.5 & 1.3324 \\
\hline 45 & 0.00314 & 66.60 & 1.8235 & 62.0 & 1.7924 & 53.5 & 1.7284 & & & 39.8 & 1.5999 & 29.2 & 1.4654 \\
\hline 50 & 0.00310 & 85.60 & 1.9325 & 79.7 & 1.9015 & 68.9 & 1.8382 & & & 52.5 & 1.7202 & 37.4 & 1.5729 \\
\hline 55 & 0.00305 & 110.90 & 2.0449 & 102.4 & 2.0103 & 89.4 & 1.9513 & & & 68.4 & 1.8351 & 49.1 & 1.6911 \\
\hline 60 & 0.00300 & 139.00 & 2.1430 & 130.0 & 2.1139 & 111.5 & 2.0473 & 101.00 & 2.0043 & 88.3 & 1.9460 & 62.7 & 1.7973 \\
\hline 65 & 0.00296 & 175.40 & 2.2440 & 163.9 & 2.2146 & 143.2 & 2.1559 & & & 112.2 & 2.0500 & 80.1 & 1.9036 \\
\hline 70 & 0.00292 & 217.00 & 2.3365 & 204.1 & 2.3098 & 179.0 & 2.2529 & & & 141.1 & 2.1495 & 101.0 & 2.0043 \\
\hline 75 & 0.00287 & 273.00 & 2.4362 & 256.2 & 2.4086 & 227.0 & 2.3560 & & & 178.2 & 2.2509 & 129.7 & 2.1129 \\
\hline 80 & 0.00283 & 334.00 & 2.5237 & 313.8 & 2.4967 & 277.0 & 2.4425 & & & 220.0 & 2.3424 & 159.6 & 2.2030 \\
\hline 85 & 0.00279 & 408.00 & 2.6107 & 385.0 & 2.5855 & 337.0 & 2.5276 & & & 272.0 & 2.4346 & 197.5 & 2.2956 \\
\hline 90 & 0.00275 & 502.00 & 2.7007 & 469.9 & 2.6720 & 415.0 & 2.6180 & & & 332.0 & 2.5211 & 243.0 & 2.3856 \\
\hline 95 & 0.00272 & 608.00 & 2.7839 & 566.5 & 2.7532 & 502.0 & 2.7007 & & & 411.0 & 2.6138 & 296.0 & 2.4713 \\
\hline 100 & 0.00268 & 718.00 & 2.8561 & 662.2 & 2.8210 & 591.0 & 2.7716 & & & 525.0 & 2.7202 & 346.0 & 2.5391 \\
\hline
\end{tabular}

(contd) 
Table B-17. (contd)

\begin{tabular}{|c|c|c|c|c|c|c|c|c|c|c|c|c|c|c|c|c|}
\hline \multirow{2}{*}{$\begin{array}{c}\text { Temp., } \\
\text { 'C }\end{array}$} & \multicolumn{2}{|c|}{$54.62 \mathrm{wt} \%$} & \multicolumn{2}{|c|}{56.06 wt\% } & \multicolumn{2}{|c|}{$62.70 \mathrm{wt} \%$} & \multicolumn{2}{|c|}{$68.34 \mathrm{wt} \%$} & \multicolumn{2}{|c|}{71.63 wt\% } & \multicolumn{2}{|c|}{74.55 wt\% } & \multirow{2}{*}{$\frac{77.83}{\mathrm{p},}$} & \multirow{2}{*}{$\frac{\text { wt\% }}{\log p}$} & \multicolumn{2}{|c|}{$83.28 \mathrm{wt} \%$} \\
\hline & $\underset{\mathrm{mm}}{\mathrm{p}}$ & $\log p$ & $\underset{\mathrm{mm} H \mathrm{Hg}}{\mathrm{p}}$ & $\log p$ & $\stackrel{p}{\mathrm{~m} m \mathrm{H} g}$ & $\log p$ & $\underset{\mathrm{mmHg}}{\mathrm{p}}$ & $\log p$ & $\stackrel{\mathrm{p}}{\mathrm{mm} H \mathrm{~g}}$ & $\log p$ & $\underset{\mathrm{mmHg}}{\mathrm{p}}$ & $\log p$ & & & $\begin{array}{c}\mathrm{p}, \\
\mathrm{mm} H g\end{array}$ & $\log p$ \\
\hline 0 & 1.1 & 0.0531 & 0.98 & -0.0110 & 0.53 & -0.2798 & 0.23 & -0.6478 & 0.13 & $\overline{0.9031}$ & 0.07 & -1.1871 & 0.03 & -1.4949 & 0.007 & -2.1549 \\
\hline 10 & 2.2 & 0.3424 & & & & & & & & & & & & & & \\
\hline 20 & 4.2 & 0.6243 & 4.20 & 0.6232 & 2.18 & 0.3385 & 1.05 & 0.0212 & 0.58 & $\overline{0.2388}$ & 0.33 & -0.4868 & 0.18 & -0.7545 & 0.052 & -1.2840 \\
\hline 25 & 6.2 & 0.7938 & 5.55 & 0.7443 & & & & & & & & & & & & \\
\hline 30 & 8.3 & 0.9206 & 7.43 & 0.8710 & & & & & & & & & & & & \\
\hline 35 & 11.2 & 1.0492 & 9.61 & 0.9827 & & & & & & & & & & & & \\
\hline 40 & 15.3 & 1.1836 & 13.40 & 1.1271 & 7.71 & 0.8871 & 3.80 & 0.5798 & 2.19 & 0.3404 & 1.28 & 0.1072 & 0.73 & -0.1367 & 0.202 & -0.6946 \\
\hline 45 & 20.1 & 1.3032 & 17.66 & 1.2470 & & & & & & & & & & & & \\
\hline 50 & 26.8 & 1.4281 & 23.70 & 1.3747 & & & & & & & & & & & & \\
\hline 55 & 34.7 & 1.5403 & 31.00 & 1.4914 & & & & & & & & & & & & \\
\hline 60 & 44.8 & 1.6513 & 40.10 & 1.6031 & 23.50 & 1.3711 & 11.98 & 1.0785 & 7.06 & 0.8488 & 4.50 & 0.6532 & 2.55 & 0.4065 & 0.783 & -0.1062 \\
\hline 65 & 57.7 & 1.7612 & 51.60 & 1.7126 & & & & & & & & & & & & \\
\hline 70 & 72.8 & 1.8621 & 65.20 & 1.8142 & & & & & & & & & & & & \\
\hline 75 & 91.6 & 1.9619 & 82.20 & 1.9149 & & & & & & & & & & & & \\
\hline 80 & 114.4 & 2.0584 & 103.70 & 2.0158 & 60.00 & 1.7782 & 31.50 & 1.4983 & 21.00 & 1.3222 & 13.49 & 1.1300 & 7.89 & 0.8971 & 2.840 & 0.4533 \\
\hline 85 & 142.5 & 2.1538 & 127.90 & 2.1069 & & & & & & & & & & & & \\
\hline 90 & 175.9 & 2.2453 & 160.30 & 2.2049 & & & & & & & & & & & & \\
\hline 95 & 214.0 & 2.3304 & 196.60 & 2.2936 & & & & & & & & & & & & \\
\hline 100 & 258.0 & 2.4116 & 231.80 & 2.3651 & 146.40 & 2.1655 & 2.1655 & 1.9025 & 54.10 & 1.7332 & 35.50 & 1.5502 & 22.00 & 1.3424 & 8.450 & 0.9269 \\
\hline
\end{tabular}

a[TARASENKOV] 
Table B-18. Constants A and B as Determined by Least-Squares Method to fit Vapor Pressure of Water Data in Table B-16 to Eq. B-3

\begin{tabular}{ccc}
\hline $\mathrm{H}_{2} \mathrm{SO}_{4}, \mathrm{wt} \%$ & $\mathrm{~A}$ & $\mathrm{~B}$ \\
\hline 10.02 & 9.004 & -2286.68 \\
20.40 & 9.030 & -2305.15 \\
29.84 & 9.070 & -2339.20 \\
39.90 & 9.406 & -2490.37 \\
48.44 & 9.026 & -2408.30 \\
54.62 & 8.938 & -2428.66 \\
56.06 & 9.174 & -2525.74 \\
62.70 & 8.838 & -2489.16 \\
68.34 & 8.835 & -2585.68 \\
71.63 & 8.920 & -2683.44 \\
74.55 & 9.026 & -2788.50 \\
77.83 & 9.053 & -2877.21 \\
83.28 & 9.230 & -3100.02 \\
\hline
\end{tabular}


Table B-19. Activity of Water over Aqueous Phosphoric Acid at $25^{\circ} \mathrm{C}$

\begin{tabular}{ccc}
\hline $\left.\mathrm{H}_{3} \mathrm{PO}_{4}\right]$, & Activity of & {$\left[\mathrm{H}_{2} \mathrm{SO}_{4}\right]$} \\
Molality & Water & Molality \\
\hline 1.0675 & 0.9782 & 0.5973 \\
1.7602 & 0.9633 & 0.9694 \\
2.9858 & 0.9331 & 1.6192 \\
4.3541 & 0.8962 & 2.3082 \\
5.1875 & 0.8690 & 2.7320 \\
9.1862 & 0.7367 & 4.5628 \\
9.5130 & 0.7231 & 4.7401 \\
10.2840 & 0.6999 & 5.0404 \\
10.9030 & 0.6774 & 5.3309 \\
11.0700 & 0.6720 & 5.4010 \\
11.1970 & 0.6669 & 5.4660 \\
11.9380 & 0.6452 & 5.7441 \\
12.6470 & 0.6237 & 6.0190 \\
13.5500 & 0.5915 & 6.4432 \\
14.0570 & 0.5765 & 6.6349 \\
15.6850 & 0.5323 & 7.2422 \\
15.9120 & 0.5237 & 7.3646 \\
18.0340 & 0.4677 & 8.1749 \\
19.0060 & 0.4432 & 8.5554 \\
20.7080 & 0.4084 & 9.1841 \\
21.3270 & 0.3937 & 9.3940 \\
21.6080 & 0.3874 & 9.5043 \\
23.5240 & 0.3528 & 10.1460 \\
24.8540 & 0.3289 & 10.6190 \\
28.2020 & 0.2778 & 11.7460 \\
28.7680 & 0.2732 & 11.8610 \\
28.9950 & 0.2649 & 12.0680 \\
31.0440 & 0.2470 & 12.5360 \\
31.9820 & 0.2366 & 12.8270 \\
33.3050 & 0.2230 & 13.2240 \\
34.0990 & 0.2167 & 13.4140 \\
35.7730 & 0.1963 & 14.0640 \\
37.8240 & 0.1857 & 14.4280 \\
41.1840 & 0.1625 & 15.2830 \\
43.0350 & 0.1518 & 15.7330 \\
50.0100 & 0.1202 & 17.2680 \\
57.2650 & 0.0957 & 18.7660 \\
64.4200 & 0.0791 & 20.0240 \\
64.6590 & 0.0786 & 20.0640 \\
74.7260 & 0.0627 & 21.6600 \\
\hline & & \\
& & \\
& & \\
& &
\end{tabular}

${ }^{a}[$ ELMORE $]$ 
Table B-20. Equilibrium Data for the Nitric Acid-Water-Sulfuric Acid System at $760 \mathrm{mmHg}^{\mathrm{a}}$

\begin{tabular}{|c|c|c|c|c|c|}
\hline $\mathrm{H}_{2} \mathrm{SO}_{4}$ & $\mathrm{HNO}_{3}$ & $\mathrm{H}_{2} \mathrm{SO}_{4}$ & $\mathrm{HNO}_{3}$ & \multirow{2}{*}{$\frac{\mathrm{HNO}_{3}}{\mathrm{~mol} \% \text { Vapor }}$} & \multirow[b]{2}{*}{ Temp., ${ }^{\circ} \mathrm{C}$} \\
\hline \multicolumn{2}{|c|}{ wt\% Liquid } & \multicolumn{2}{|c|}{ mol\% Liquid } & & \\
\hline 7.45 & 40.80 & 2.10 & 18.20 & 7.00 & 114.30 \\
\hline 7.38 & 43.40 & 2.16 & 19.60 & 8.75 & 115.50 \\
\hline 7.51 & 59.50 & 2.70 & 33.10 & 35.20 & 120.20 \\
\hline 6.80 & 64.00 & 2.50 & 37.50 & 46.50 & 120.00 \\
\hline 6.90 & 74.00 & 3.00 & 51.00 & 85.60 & 110.00 \\
\hline 19.70 & 15.81 & 5.00 & 6.22 & 0.15 & 109.90 \\
\hline 20.10 & 22.60 & 5.47 & 9.57 & 3.11 & 112.80 \\
\hline 20.10 & 29.50 & 5.90 & 13.50 & 7.03 & 115.80 \\
\hline 20.50 & 35.50 & 6.52 & 17.50 & 14.70 & 118.70 \\
\hline 19.80 & 41.30 & 6.69 & 21.71 & 26.58 & 121.25 \\
\hline 19.50 & 46.70 & 7.06 & 26.30 & 44.50 & 122.20 \\
\hline 19.80 & 53.20 & 7.93 & 33.16 & 74.74 & 117.40 \\
\hline 38.20 & 6.74 & 10.96 & 3.01 & 1.89 & 115.30 \\
\hline 37.50 & 9.53 & 11.00 & 4.35 & 3.96 & 116.90 \\
\hline 37.00 & 12.60 & 11.20 & 5.93 & 5.26 & 118.50 \\
\hline 37.60 & 16.40 & 11.97 & 8.13 & 9.80 & 121.30 \\
\hline 37.70 & 21.60 & 12.86 & 11.47 & 20.02 & 123.10 \\
\hline 37.00 & 24.90 & 13.10 & 13.50 & 26.20 & 125.10 \\
\hline 38.10 & 29.25 & 14.57 & 17.41 & 48.46 & 125.70 \\
\hline 37.20 & 33.30 & 14.90 & 20.75 & 63.61 & 125.25 \\
\hline 37.60 & 41.20 & 17.40 & 29.40 & 92.50 & 112.50 \\
\hline 49.80 & 2.38 & 15.90 & 1.17 & 1.93 & 124.10 \\
\hline 48.75 & 4.50 & 15.70 & 2.26 & 3.84 & 124.95 \\
\hline 50.10 & 9.12 & 17.50 & 4.96 & 13.50 & 129.50 \\
\hline 49.75 & 13.55 & 18.37 & 7.79 & 29.50 & 132.30 \\
\hline 50.00 & 15.90 & 18.15 & 9.50 & 42.96 & 131.20 \\
\hline 50.00 & 18.40 & 20.00 & 11.40 & 57.50 & 130.10 \\
\hline 50.60 & 26.20 & 23.40 & 18.80 & 93.70 & 123.00 \\
\hline 51.00 & 30.15 & 24.90 & 22.80 & 97.70 & 115.90 \\
\hline 59.80 & 0.81 & 21.70 & 0.45 & 2.08 & 140.50 \\
\hline 59.00 & 1.67 & 21.39 & 0.94 & 4.58 & 138.00 \\
\hline 60.50 & 2.59 & 22.80 & 1.51 & 7.90 & 141.50 \\
\hline 60.40 & 3.94 & 23.35 & 2.37 & 13.30 & 142.20 \\
\hline 60.00 & 6.04 & 23.70 & 3.70 & 25.20 & 141.35 \\
\hline 59.95 & 9.18 & 25.00 & 5.94 & 45.10 & 137.60 \\
\hline 59.10 & 11.72 & 25.10 & 7.72 & 59.30 & 134.40 \\
\hline 60.00 & 14.72 & 27.20 & 10.38 & 84.45 & 129.40 \\
\hline 70.10 & 0.29 & 30.20 & 0.19 & 2.58 & 161.40 \\
\hline 69.25 & 0.68 & 29.60 & 0.45 & 5.86 & 163.00 \\
\hline 70.43 & 0.93 & 30.91 & 0.62 & 9.47 & 165.00 \\
\hline
\end{tabular}

(contd) 
Table B-20. (contd)

\begin{tabular}{|c|c|c|c|c|c|}
\hline $\mathrm{H}_{2} \mathrm{SO}_{4}$ & $\mathrm{HNO}_{3}$ & $\mathrm{H}_{2} \mathrm{SO}_{4}$ & $\mathrm{HNO}_{3}$ & \multirow{2}{*}{$\frac{\mathrm{HNO}_{3}}{\text { mol\% Vapor }}$} & \multirow[b]{2}{*}{ Temp., ${ }^{\circ} \mathrm{C}$} \\
\hline \multicolumn{2}{|c|}{ wt\% Liquid } & \multicolumn{2}{|c|}{ mol\% Liquid } & & \\
\hline 70.00 & 1.30 & 30.70 & 0.87 & 13.30 & 165.80 \\
\hline 69.90 & 2.02 & 31.00 & 1.39 & 21.00 & 164.60 \\
\hline 69.80 & 3.05 & 31.38 & 2.13 & 34.66 & 162.00 \\
\hline 69.40 & 4.28 & 32.80 & 3.10 & 53.00 & 152.20 \\
\hline 68.80 & 7.20 & 32.70 & 5.30 & 77.30 & 144.50 \\
\hline 70.00 & 8.46 & 34.90 & 6.60 & 95.60 & 137.50 \\
\hline 80.50 & 0.19 & 43.30 & 0.15 & 4.70 & 198.30 \\
\hline 79.25 & 0.44 & 41.60 & 0.32 & 10.00 & 196.60 \\
\hline 80.40 & 0.65 & 43.60 & 0.54 & 19.73 & 197.90 \\
\hline 81.00 & 0.95 & 44.80 & 0.81 & 29.55 & 196.60 \\
\hline 80.20 & 1.15 & 43.50 & 0.96 & 34.60 & 193.90 \\
\hline 80.70 & 1.31 & 44.60 & 1.12 & 53.80 & 195.60 \\
\hline
\end{tabular}

a[ELLIS] 


\section{$\underline{\text { References for Appendix B }}$}

\section{BARNOV}

A. V. Barnov and V. G. Karev, "Effect of Nitrates on the Relative Volatilities of Nitric Acid in" its Aqueous Solutions," Russian J. Phys. Chem. 41 (6), 696 (1967).

BERL

Von E. Berl, K. Andress, and E. Escales, "Beitrage zur Kenntnis der Mischsaure," Kunststoffe, p. 23 (1937).

\section{EFIMOV-1970}

A. N. Efimov, M. I. Zhikharev, and Yu. P. Zhirnov, "Liquid-Vapor Equilibrium in the System $\mathrm{HNO}_{3}-\mathrm{H}_{2} \mathrm{O}-\mathrm{UO}_{2}\left(\mathrm{NO}_{3}\right)_{2}$ at Pressures of 180,360 , and $720 \mathrm{mmHg}$," Soviet Radiochemistry $\underline{12}$ (5), 732 (1970).

\section{EFIMOV-1973}

A. N. Efimov, M. I. Zhikharev, and Yu. P. Zhirnov, "The Liquid-Vapour Equilibria in Nitric Acid-Water-Copper (II) Nitrate and Nitric Acid-Water-Beryllium Nitrate System," Russian J. Phys. Chem. 47(11), 1652 (1973).

\section{EFIMOV-1974}

A. N. Efimov, M. I. Zhikharev, and Zh. P. Zhirnov, " Liquid - Vapor Equilibrium in the System $\mathrm{HNO}_{3}-\mathrm{H}_{2} \mathrm{O}-\mathrm{NaNO}_{3}$ and Variations of Boiling Point with Variations of the Liquid Composition Along Joins and Transversals of the Triangular Diagram," J. Appl. Chem. USSR 47(9), 2183 (1974).

\section{EFIMOV-1975}

A. N. Efimov, M. I. Zhikharev, and Yu. P. Zhirnov, "Physicochemical Basis and Calculation of Vaporization Process for Highly Active Nitric Acid Solutions," Soviet Atomic Energy $\underline{39}$ (6), 1074 (1975).

\section{ELLIS}

S. R. M. Ellis and J. M. Thwaites, "Vapour-Liquid Equilibria of Nitric Acid-Water-Sulphuric Acid Mixtures," J. Appl. Chem. I, 152 (1957).

\section{ELMORE}

Kelly L. Elmore, Charles M. Mason, and James H. Christensen, "Activity of Orthophosphoric Acid in Aqueous Solution at $25^{\circ} \mathrm{C}$ from Vapor Pressure Measurements," J. Am. Chem. Soc. 68, 2528 (1946).

\section{FLATT}

Par R. Flatt and J. Bonnet, " Sur l' equilibre liquide-vapeur du systeme ternaire $\mathrm{H}_{3} \mathrm{PO}_{4}$ $\mathrm{HNO}_{3}-\mathrm{H}_{2} \mathrm{O}$ Les trajectoires de distillation des melanges composes d'acide phosphorique, d'acide nitrique et d'eau," Chimia 12(12), 343 (1958).

\section{FONTANA}

B. J. Fontana, "The Vapor Pressure of Water over Phosphoric Acids," J. Am. Chem. Soc. 73, 3348 (1951). 
HALA-1958

E. Hala, I. Wichterle, J. Polak, and T. Boublik, Vapour-Liquid Equilibrium Data at Normal

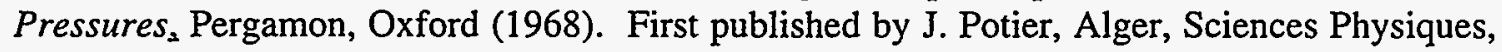
4, 98 (1958).

HALA-1960

E. Hala, I. Wichterle, J. Polak, and T. Boublik, Vapour-Liquid Equilibrium Data at Normal

Pressures, Pergamon, Oxford (1968). First published by T. Boublik and A. Kuchynka, Coll.

Czeh. Chem. Comm. 25, 579 (1960).

HALA-1968

E. Hala, I. Wichterle, J. Polak, and T. Boublik, Vapour-Liquid Equilibrium Data at Normal Pressures $_{2}$ Pergamon, Oxford (1968). First published by J. Prosek, Thesis, UTZCHT-CSAV, Prague (1965).

\section{PETROV}

M. R. Petrov, Yu. P. Zhirnov, and M. I. Zhikharev, "Liquid-Vapour Equilibrium in the Nitric Acid-Water-Phosphoric Acid System," Russian J. Phys. Chem. 49 (3), 469 (1975).

POLOVNIKOVA

G. T. Polovnikova, L. I. Chentsova, and L. N. Nosova, "Liquid-Vapour Equilibrium in Systems Comprising Aqueous Solutions of Nitric Acid and Sulphates," Russian J. Inorganic Chem. 16(12), 1759 (1971).

\section{SHNEERSON}

A. L. Shneerson, M. A. Miniovich, Zh. M. Filippova, S. N. Soroka, and P. A. Platonov, "Liquid-Vapour Equilibrium in the Systems Nitric Acid-Water-Magnesium Nitrate, Nitric Acid-Water-Calcium Nitrate, and Nitric Acid-Magnesium Nitrate-Calcium Nitrate," Russian J. Phys. Chem. $\underline{39}(6), 744$ (1965).

\section{TARASENKOV}

D. N. Tarasenkov, "Vapor Pressure of Aqueous Sulfuric Acid Solutions," J. Applied Chem. USSR 28 (10), 1053 (1955).

WICHTERLE-1973

I. Wichterle, J. Polak, and E. Hala, Vapor-Liquid Equilibrium Data Bibliography, Elsevier, Amsterdam (1973).

WICHTERLE-1976

I. Wichterle, J. Polak, and E. Hala, Vapor-Liquid Equilibrium Data Bibliography Supplement

I, Elsevier, Amsterdam (1976).

WICHTERLE-1979

I. Wichterle, J. Polak, and E. Hala, Vapor-Liquid Equilibrium Data Bibliography Supplement II, Elsevier, Amsterdam (1979).

WICHTERLE-1982

I. Wichterle, J. Polak, and E. Hala, Vapor-Liquid Equilibrium Data Bibliography Supplement III, Elsevier, Amsterdam (1982). 
WICHTERLE-1985

I. Wichterle, J. Polak, and E. Hala, Vapor-Liquid Equilibrium Data Bibliography Supplement $I V$, Elsevier, Amsterdam (1985).

\section{ZHIKAREV}

M.I. Zhikharev, M.R. Petrov, and D.N. Roslyakova, "Liquid-Vapor Equilibrium in the System $\mathrm{HNO}_{3}-\mathrm{H}_{2} \mathrm{O}-\mathrm{Fe}\left(\mathrm{NO}_{3}\right)_{3}-\mathrm{Cu}\left(\mathrm{NO}_{3}\right)_{2}$," J. Appl. Chem. USSR 59 (5), 1020 (1986). 


\section{APPENDIX C}

\section{$\underline{\text { Neutron Activation Analysis }}$}

During normal operation of the evaporator, a decontamination factor (DF) of $10^{5}$ to $10^{7}$ must be attained. The decontamination factor is defined as follows:

$$
\mathrm{DF}=\frac{\text { Liquid-Phase Concentration }}{\text { Vapor-Phase Concentration }}
$$

A DF of $10^{7}$ means that the concentration in the vapor phase is $10^{-7}$ less than the concentration in the liquid phase. Radioactive tracers seem ideally suited for measuring decontamination factors in the evaporator. Detection limits for tracers are typically very low, so DFs of $10^{5}-10^{7}$ would be easily measured; however, they would contaminate the equipment, complicating future work on the evaporator and increasing the costs for installing the evaporator and for conducting future tests. In addition, using radioactivity is prohibited at LICON (Pensacola, FL). Therefore, an analytical method is needed to measure low concentrations of an element. One such procedure is neutron activation analysis (NAA). This method is described in detail below.

\section{Neutron Activation}

\section{a. Description}

Neutron activation is simply the creation of a radioactive element as the result of neutron interaction with a stable isotope. When a neutron (n) collides with a nucleus, the following reactions may occur: elastic scattering $(n, n)$, inelastic scattering $\left(n, n^{\prime}\right)$, radiative capture $(n, \gamma)$, chargeparticle reaction $(n, \alpha)$ or $(n, p)$, neutron producing reaction $(n, 2 n)$ and fission $(n, f)$. These reactions occur according to their neutron interaction cross section. This cross section is simply the probability that a neutron will interact with the target. The most useful reaction in NAA is radiative capture, which can be denoted as

$$
\mathrm{n}+{ }^{\mathrm{A} Z} \rightarrow^{\mathrm{A}+1} \mathrm{Z}^{*} \rightarrow^{\mathrm{A}+1} \mathrm{Z}+\gamma
$$

where ${ }^{A+1} Z^{*}$ is called the compound nucleus, which is usually in an excited state (noted by the *). It can de-excite by emitting gamma ray called a "prompt gamma." In many cases the ${ }^{A+1} \mathrm{Z}$ also decays by emitting gamma rays called "delayed gammas." These delayed gammas can be detected using a high-resolution, gamma-sensitive detector.

\section{b. $\quad$ NAA Facilities}

Neutron activation analysis is performed at the University of Illinois. The operating TRIGA reactor, using the "lazy-susan" facility, can provide a thermal neutron flux of $3.3 \times 10^{12}$ neutrons $\mathrm{cm}^{-2} \mathrm{sec}^{-1}$ at $1.5 \mathrm{MW}$ and can irradiate up to 80 samples simultaneously. For higher neutron fluxes, an in-core facility for thermal $\left(1.2 \times 10^{13}\right.$ neutrons $\mathrm{cm}^{-2} \mathrm{sec}^{-1}$ at $\left.1.5 \mathrm{MW}\right)$ and epithermal $\left(1.0 \times 10^{12}\right.$ neutrons $\mathrm{cm}^{-2} \mathrm{sec}^{-1}$ at $\left.1.5 \mathrm{MW}\right)$ irradiation positions are also available. The NAA facility is located in the Materials Research Laboratory. It is equipped with three distinct counting systems: a 19\%-efficient germanium detector in conjunction with a sodium iodide Compton suppression system; a 13\%-efficient germanium detector with a beryllium window capable 
of detecting both $\mathrm{x}$ - and gamma-rays, and a $24 \%$-efficient germanium detector in conjunction with a sample changer. All data collection and analysis routines incorporate ORTEC hardware and software using three personal computers.

\section{c. Radioisotope for Determining DF}

To use neutron activation analysis for measuring DFs in the evaporator, a stable, inexpensive element with a large cross section for radiative capture is necessary. Therefore, we reviewed the elements and identified samarium as an element suitable for our application.

Samarium-152 has a radiative capture cross section $\sigma_{\gamma}$ of 208 barns. The radiative capture reaction produces ${ }^{153} \mathrm{Sm}$, which has a half-life of $1.929 \mathrm{~d}$, and emits a $103.2 \mathrm{keV}$ gamma-ray. The two-day half-life allows sufficient time for analysis and relatively rapid decay, so radioactive waste production is not a concern. An example of a gamma spectrum from an irradiated samarium standard is shown in Fig. $\mathrm{C}-1$.

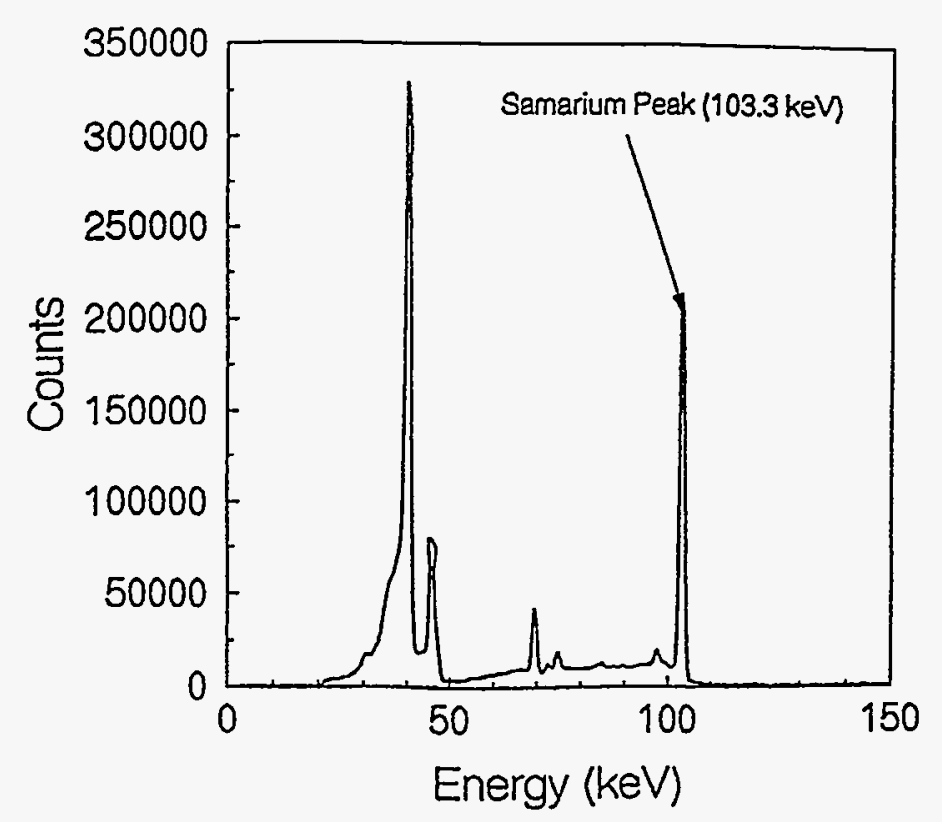

Fig. C-1. Gamma Spectrum from Irradiated Samarium Standard

\section{d. Sample Preparation Procedure}

1. Pipet an aliquot of sample solution into a $1.5-\mathrm{ml}$ polyethylene vial. Label vial with the sample identification.

2. Pipet a certified standard of the same salt in a similar system into an identical vial, and label.

3. Heat-seal vials.

4. Place each $1.5 \mathrm{ml}$ vial into a larger vial, heat-seal and label. This prevents leakage of the sample into the reactor or laboratory facilities.

5. Fill out the appropriate paperwork for the reactor. Include the following information: 

a. Vial contents
b. Configuration (small vial inside larger vial)
c. Location in reactor where samples will be irradiated
d. Power at which irradiation should occur
e. Length of irradiation time
f. Date samples should be irradiated
g. Date samples will be picked up from the reactor
h. Name of person responsible for samples
i. Account that will be charged for reactor use

6. Transfer vials and paperwork to the reactor facility.

7. After irradiation, samples will be monitored by reactor health physicists.

8. After their approval, pick up samples at the reactor and place them in a lead-lined container for transportation to laboratory.

9. Transfer samples into new, uncontaminated vials as follows:
a. Label and weigh new vials.
b. Open old vials and pipet samples to corresponding new vials.
c. Close new vials and weigh.

10. Sample weight is calculated by taking the difference between the weights of the vial + sample and the empty vial.

11. Count standard and sample using the same detector and the same geometry.

12. Determine concentrations using equations in Sect. e.

\section{e. Calculations to Convert Counts to Concentration}

The number of radioactive atoms produced during irradiation is measured in terms of the rate of decrease or decay of the induced radioactivity. The law of radioactive decay states that the number of atoms that disintegrate per unit time $\left(\mathrm{dN}^{*} / \mathrm{dt}\right)$ is proportional to the total number of radioactive atoms, $\mathrm{N}^{*}$, present. Hence

$$
\frac{\mathrm{dN}^{*}}{\mathrm{dt}}=-\lambda \mathrm{N}^{*}
$$

where $\lambda$ is the radioactive decay constant, which has a characteristic value for each nuclide. It represents the probability that an atom will decay in a unit time. Integration of Eq. C-3 yields

$$
N^{*}(t)=N_{0} e^{-\lambda t}
$$

where $\mathrm{N}_{0}$ is the number of radioactive atoms present at some original time, $t=0$, and $\mathrm{N}^{*}$ indicates the number present at time $t$. The decay constant is related to the radioactive half-life $\left(t_{1 / 2}\right)$ as follows:

$$
\gamma=\frac{0.693}{t_{1 / 2}}
$$


Since half-life data are readily available, one can easily determine the decay constant by Eq. C-5.

During irradiation, radioactive nuclei are produced, assuming that a single radionuclide is produced, the increase in number of radionuclides is the product of the neutron flux, . $\phi$, the neutron activation cross section, $\sigma_{\text {act }}$, and the number of stable target nuclei, $N$. The rate of change of radioactive atoms during irradiation is given by

$$
\frac{\mathrm{dN}^{*}}{\mathrm{dt}}=\sigma_{\mathrm{act}} \phi \mathrm{N}-\lambda \mathrm{N}
$$

Thus, the first term in Eq. C-6 accounts for production and the second term for decay. Integrating Eq. C-6 over the irradiation time $\left(t_{i}\right)$ yields

$$
\mathrm{N}^{*}\left(\mathrm{t}_{\mathrm{i}}\right)=\frac{\sigma_{\mathrm{act}} \mathrm{fN}}{\lambda}\left(1-\mathrm{e}^{-\lambda \mathrm{t}_{\mathrm{i}}}\right)
$$

As activation proceeds, there is an increase in activity, but the rate of growth of the activity diminishes with time. Thus, irradiation times are usually limited to one half-life, since eight times as much activation only doubles the activity. For irradiation times less than one half-life, the amount of induced activity is nearly proportional to the activation time.

The number of radioactive nuclei present is a maximum at the end of irradiation. So after a fixed irradiation time, $t_{i}$, the number of radioactive nuclei present, $N^{*}$, after some decay time, $t_{d}$, is given by Eq. C-8 [KNOLL].

$$
N^{*}=\frac{\sigma_{a c t} \phi N}{\lambda}\left(1-\mathrm{e}^{-\lambda t_{i}}\right) \mathrm{e}^{-\lambda t_{d}}
$$

Not all the radioactive nuclei $\mathrm{N}^{*}$ in Eq. C-8 decay during a finite counting time, $\mathrm{t}_{\mathrm{c}}$. In practical applications, a sample is irradiated for a time $t_{i}$, allowed to cool during a decay time $t_{d}$, and counted for a time $t_{c}$. These three time variables are chosen to optimize the analytical sensitivity of the radionuclide of interest. The number of radioactive nuclei which decay during a counting time $t_{c}$ is given by

$$
N^{*}=\frac{\sigma_{a c t} \phi N}{\lambda}\left(1-e^{-\lambda t_{i}}\right) e^{-\lambda t_{d}}\left(1-e^{-\lambda t_{c}}\right)
$$

Of all the radioactive nuclei that decay during $t_{c}$, not all decay by the same mode. The fraction of decays which occur by a particular mode is given by the intensity $\mathrm{I}_{\gamma}$ of the emitted $\gamma$-rays at a given energy. Furthermore, only a fraction of the radiation emitted by the sample is "visible" to the detector. Since $\gamma$-rays are emitted isotropically during decay, the detector can only see the radiation that subtends the solid angle from the source to the detector. Also, the $\gamma$-rays entering the detector do not always interact to produce a distinct count. The fraction of the $\gamma$-rays seen by the detector is the efficiency $\varepsilon_{\gamma}$ of the detector for this $\gamma$-ray. Combining these factors with the previous expression yields Eq. C-10 for the counts measured. 


$$
\mathrm{N}^{*}=\frac{\sigma_{\mathrm{act}} \phi \mathrm{N}}{\lambda}\left(1-\mathrm{e}^{-\lambda \mathrm{t}_{\mathrm{i}}}\right) \mathrm{e}^{-\lambda \mathrm{t}_{\mathrm{d}}}\left(1-\mathrm{e}^{-\lambda \mathrm{t}_{\mathrm{c}}}\right) \mathrm{I}_{\gamma} \varepsilon_{\gamma}
$$

Typically, comparative methods such as NAA irradiate standards and samples together and count both with the same detector using identical geometric configurations. Then the ratio of unknown (sample) counts to known (standard) counts measured is

$$
\frac{N_{u}^{*}}{N_{k}^{*}}=\frac{N_{u}}{N_{k}} \frac{e^{-\lambda t_{d u}}}{e^{-\lambda t_{d k}}} \frac{\left(1-e^{-\lambda t_{c u}}\right)}{\left(1-e^{-\lambda t_{c k}}\right)}
$$

where the subscripts $\mathrm{u}$ and $\mathrm{k}$ denote unknown sample and known standard, respectively. The number of target nuclei $\mathrm{N}$ is a product of concentration $\mathrm{C}$ and mass $\mathrm{m}$. If samples and standards are counted for the same length of time, Eq. C-11 can be rewritten (Eq. C-12) solving for the concentration of the unknown sample.

$$
C_{u}=C_{k} \frac{m_{k}}{m_{u}} \frac{N_{u}^{*}}{N_{k}^{*}} \frac{e^{-\lambda t_{d u}}}{e^{-\lambda t_{d k}}}
$$

If the samples and standards are irradiated at different times, then flux monitors are employed to account for any variations in neutron fluence.

\section{Detection Limits}

To be certain that we can determine the desired DFs for the evaporator, we needed to determine the DFs for samarium in our system. According to Currie [CURRIE], a detection limit is the minimum value at which a given analytical procedure may be relied upon to lead to detection. This detection limit is defined as

$$
\mathrm{L}_{\mathrm{D}}=2.71+4.65 \sqrt{\mu_{\mathrm{B}}}
$$

where $\mu_{B}$ is the average background count. For NAA, this value corresponds to the minimum number of net counts recorded at which a given analytical procedure may be relied upon to lead to detection.

To find the detection limit, the average background counts must be determined. The photopeak for samarium is centered at $103.20 \mathrm{keV}$. An example of a samarium photopeak was shown previously in Fig. C-1. The area under this peak represents the total number of counts for the samarium plus the background. To determine the average background it is necessary to define two regions of interest (ROI) on either side of the photopeak. The area in each region is then divided by the number of channels in the respective ROI to get background counts per channel. The average background counts, $m_{B}$, is then determined by

$$
\mu_{B}=\frac{C_{L}+C_{R}}{2} \cdot \text { Number of Peak Channels }
$$


where $C_{L}$ and $C_{R}$ are the counts per channel to the left and right of the photopeak. [KNOLL].

Detection limits may also be related to physical quantities. For example, the detection limit, $L_{\mathrm{D}}$, may be related to the minimum detectable concentration by means of

$$
\mathrm{L}_{\mathrm{D}}=\mathrm{KC}_{\mathrm{D}}
$$

where $\mathrm{K}$ represents an overall calibration factor relating the detector response to the concentration present and $C_{D}$ represents the minimum detectable concentration. For NAA, $K$ would be equal to the net counts per concentration unit (net counts/ppm)

$$
C_{D}=\frac{L_{D}}{K}
$$

\section{$\underline{\text { References for Appendix C }}$}

\section{CURRIE}

L. A. Currie, "Limits for Qualitative Detection and Quantitative Determination," Analytical Chemistry $\underline{3}, 586$ (1968).

\section{KNOLL}

G. F. Knoll, Radiation Detection and Measurement, 2nd Ed., John Wiley, New York (1989). 


\section{APPENDIX D \\ Relationship between Activity and Chemical Potential}

The chemical potential of a species $i$ in a solution is expressed by

$$
\mu_{i}=\left(\frac{\partial G}{\partial n_{i}}\right)_{P, T, n_{j}}
$$

where $G$ is the Gibbs free energy, $n_{i}$ is the number of moles of $i$, and $n_{j}$ represents all other species.

In terms of chemical potential, an ideal solution is defined as

$$
\mu_{i}=\mu_{i}^{0}+R T \ln \chi_{i}
$$

where $\chi_{i}$ is the mole fraction of species $i, \mu_{i}^{\circ}$ is the chemical potential of species $i$ at the standard state [(which for ideal solutions is $\left.\lim \left(\chi_{\mathrm{i}} \rightarrow 1\right)\right], \mathrm{R}$ is the universal gas constant $(8.3144 \mathrm{~J} / \mathrm{mol} / \mathrm{K})$, and $\mathrm{T}$ is temperature of the solution $(\mathrm{K})$. For any solution, thermodynamics dictates that

$$
\mu_{\mathrm{i}}=\mu_{\mathrm{i}}^{0}+\mathrm{RT} \ln \mathrm{a}_{\mathrm{i}}
$$

where $a_{i}$ is the activity of species $i$ and is a function of $T, \chi_{1}, \chi_{2}, \ldots$. Subtracting Eq. D-2 from Eq. D-3 we obtain the expression

$$
R T \ln a_{i}-R T \ln \chi_{i}=R T \ln \left(\frac{a_{i}}{\chi_{i}}\right)=0
$$

The quantity $\left(a_{\mathrm{i}} / \chi_{\mathrm{i}}\right)$ measures the departure of species $\mathrm{i}$ from ideality; it is called the activity coefficient and is represented by gi. Since $a_{i}=\gamma_{i} \chi_{i}$, Eq. 3 can be rewritten as

$$
\mu_{\mathrm{i}}=\mu_{\mathrm{i}}^{0}+\mathrm{RT} \ln \left(\gamma_{\mathrm{i}} \chi_{\mathrm{i}}\right)
$$

The standard-state term $\mu_{i}^{\circ}$ for non-ideal systems follows either of two conventions. Convention 1 states that for any solution in which the $\chi$ for all components can be varied over a considerable range, the standard state for each component, $i$, is taken as the pure liquid $i$ at temperature $\mathrm{T}$ and pressure $\mathrm{P}$. Therefore, as $\chi \rightarrow 1$

$$
\mu_{\mathrm{i}}=\mu_{\mathrm{i}}^{0}+\mathrm{RT} \ln \gamma_{\mathrm{i}}
$$


or $\gamma \rightarrow 1$ as $\chi \rightarrow 1$. Convention 2 is used when treating one solution component (the solvent, $\mathrm{A}$ ) differently from the others (solutes, $i$ ). In this case, as $\chi_{A} \rightarrow 1$ then $\gamma_{A} \rightarrow 1$; however, for solutes, $\gamma_{i} \rightarrow 1$ as $\chi_{i} \rightarrow 0$. This is the case of infinite dilution for species $i$.

To clarify the significance of $\gamma$, let us introduce the excess Gibbs energy,

$$
\mathrm{G}^{\mathrm{E}} \equiv \mathrm{G}^{\mathrm{act}}-\mathrm{G}^{\mathrm{id}}
$$

Thus, $\mathrm{G}^{\mathrm{E}}$ is defined as the actual Gibbs free energy of the actual solution minus the Gibbs free energy of the ideal solution where,

$$
\mathrm{G}^{\mathrm{act}}=\sum_{\mathrm{i}} \mathrm{n}_{\mathrm{i}}\left(\mu_{\mathrm{i}}^{*}+\mathrm{RT} \ln \gamma_{\mathrm{i}} \chi_{\mathrm{i}}\right)
$$

and

$$
G^{\mathrm{id}}=\sum_{\mathrm{i}} \mathrm{n}_{\mathrm{i}}\left(\mu_{\mathrm{i}}^{*}+\mathrm{RT} \ln \chi_{\mathrm{i}}\right)
$$

By combining Eqs. D-7, D-8, and D-9, we obtain the expression:

$$
G^{E}=R T \sum_{i}\left(n_{i} \ln \gamma_{i}\right)
$$

Consequently, if $\gamma$ is greater than 1 , then the $G^{E}$ is positive and the system is less stable than the corresponding ideal solution. If $\gamma$ is less than 1 , the excess Gibbs energy is negative and the solution is more stable than the ideal state. 
Distribution for ANL-95/23

Internal:
B. D. Babcock
B. A. Buchholz
D. B. Chamberlain (20)
L. Chen
M. K. Clemens
C. Conner
J. M. Copple
J. C. Cunnane
D. Dong
D. W. Green

J. E. Harmon

J. Sedlet

J. E. Helt

E. P. Horwitz

S. A. Slater

J. C. Hutter

M. A. Sodaro

J. J. Laidler

B. Srinivasan

R. A. Leonard

M. J. Steindler

C. J. Mertz

H. J. No

D. M. Strachan

L. Nunez

M. C. Regalbuto

G. F. Vandegrift

R. D. Wolson

D. G. Wygmans

PRS File

\section{External:}

DOE-OSTI (2)

ANL-E Library (2)

ANL-W Library

Manager, Chicago Operations Office, DOE

A. Bindokas, DOE-CH

J. Haugen, DOE-CH

A. L. Taboas, DOE-CH/AAO

Chemical Technology Division Review Committee Members:

E. R. Beaver, Monsanto Company, St. Louis, MO

D. L. Douglas, Consultant, Bloomington, $\mathrm{MN}$

R. K. Genung, Oak Ridge National Laboratory, Oak Ridge, TN

J. G. Kay, Drexel University, Philadelphia, PA

G. R. St. Pierre, Ohio State University, Columbus, $\mathrm{OH}$

J. Stringer, Electric Power Research Institute, Palo Alto, CA

J. B. Wagner, Arizona State University, Tempe, AZ

S. Betts, Los Alamos National Laboratory, Los Alamos, NM

L. O. Dworjanyn, Savannah River Technical Center, Aiken, SC

V. Fouler, Oak Ridge National Laboratory, Oak Ridge, TN

C. W. Frank, USDOE, Office of Technology Development, Washington, DC

D. Johnson, Spring Arbor College, Spring Arbor, MI

M. D. Kaminski, University of Illinois at Urbana-Champaign, Urbana, IL

S. Landsberger, University of Illinois at Urbana-Champaign, Urbana, $\mathbb{L}$

S. C. Lien, USDOE, Office of Technology Development, Germantown, MD

A. Lucero, Oak Ridge National Laboratory, Oak Ridge, TN

C. P. McGinnis, Oak Ridge National Laboratory, Oak Ridge, TN

A. C. Muscatello, LATO Office, Rocky Flats Plant, Golden, CO

A. L. Olson, Lockheed Idaho Technology Company, Idaho Falls, ID 
M. Palmer, Los Alamos National Laboratory, Los Alamos, NM

G. Pfennigworth, Martin Marietta Energy Systems, Oak Ridge, TN

S. Robinson, Oak Ridge National Laboratory, Oak Ridge, TN

P. S. Schaus, Westinghouse Hanford Company, Richland, WA

I. R. Tasker, Waste Policy Institute, Gaithersburg, MD

M.Thompson, Westinghouse Savannah River Company, Aiken, SC

T. A. Todd, Lockheed Idaho Techology Company, Idaho Falls, ID 


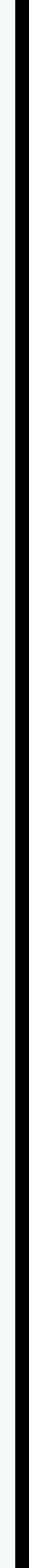

